Daniel Fujisaka

Agostinho e os maniqueus:

análise a partir "das duas almas"

(versão corrigida) 


\section{Daniel Fujisaka}

Agostinho e os maniqueus: análise a partir "das duas almas"

(versão corrigida)

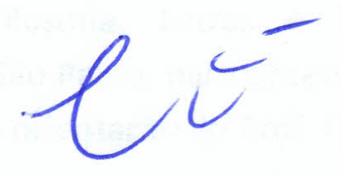




\title{
Daniel Fujisaka
}

\section{Agostinho e os maniqueus: análise a partir "das duas almas"}

\author{
(versão corrigida)
}

\begin{abstract}
Dissertação de mestrado apresentada ao programa de PósGraduação em Filosofia do Departamento de Filosofia da Faculdade de Filosofia, Letras e Ciências Humanas da Universidade de São Paulo, para obtenção do título de Mestre em Filosofia sob a orientação do Prof. Dr. Lorenzo Mammì
\end{abstract}

São Paulo

2014 
Perambulou sem rumo. O sol já se punha. Uma angústia espantosa se apoderava dele nos últimos tempos. Não tinha nada de especialmente aguda ou azeda, mas emanava dela algo de constante, de eterno; fazia pressentir anos e anos dessa dor fria, dessa angústia mortal sem escape; fazia pressentir toda a eternidade num instante. Essa sensação costumava atingi-lo com mais força ao cair da tarde.

Fiodor Dostoiévski. Crime e Catigo 


\section{Agradecimentos}

Agradeço ao professor Lorenzo Mammì que, desde a graduação, tem me inspirado e de muitas maneiras me orientado na disciplina filosófica; pela análise fina e atenciosa que dedicou a todas minhas questões; pela leitura pormenorizada de todos os textos que the enviei. Esse trabalho busca de algum modo imitá-lo em inteligência e sensibilidade.

Ao professor Moacyr Novaes, a quem devo a primeiro faísca que culminou na pesquisa filosófica. Foi quem, ainda nos primeiros anos da graduação, após singela apresentação de um seminário, dirigiu-me palavras encorajadoras que me incentivaram a prosseguir.

Aos professores Carlos Arthur R. do Nascimento, José Carlos Estêvão e Carlos Eduardo de Oliveira que no início do mestrado contribuíram imensamente com significativos apontamentos sobre o projeto, além de me receberem tão bem em nossa comunidade filosófica.

Aos professores que me ajudaram na qualificação, Moacyr Novaes e Cristiane N. A. Ayoub. Suas contribuições foram determinantes.

Aos funcionários da secretaria do Departamento de Filosofia.

Aos colegas do CEPAME. Aprendo e me divirto muito com vocês.

Aos meus pais, Kazunori e Matilde Fujisaka, pelo suporte em todo caminho.

Aos queridos amigos e irmãos, Lucas Fujisaka e Alexandre Polac, pela revisão do texto.

A Ana Paula pelo amor e companheirismo. Dedico esse trabalho a você. Não poderia ser diferente. 
A CAPES pela bolsa concedida. 


\section{RESUMO}

FUJISAKA, D. Agostinho e os maniqueus: análise a a partir das "duas almas". 2014. 228 f. Dissertação (Mestrado) - Faculdade de Filosofia, Letras e Ciências Humanas. Departamento de Filosofia, Universidade de São Paulo, São Paulo, 2014.

Pretendemos demonstrar como Agostinho reconduz a questão gnóstico-maniqueia das "duas almas" para o campo da interioridade humana, associando vida e alma como bens compreendidos pelo intelecto e, consequentemente, irredutivelmente verdadeiros. Na primeira parte da dissertação, buscamos os traços da questão no livro III das Confissões, parágrafos 1,1 à 6,12 , em duplo interesse quanto a noção de pecado: primeiro, como ser ou ausência de ser, defectus da vontade individual; em seguida, como miséria - herança de uma impotência dejá lá e sintoma de uma situação de dessemelhança (regio dissimilitunis). Essa dupla visada tem o intuito de verificar possibilidades de assimilação e afastamento da gnose-maniqueia, a fim de que possamos seguir os argumentos filósofo de Hipona no enfrentamento do problema da existência da alma má em um tratado de 392, Sobre as Duas Almas (De duabus animabus) - segunda parte de nosso trabalho. Nessa obra, o bispo procura derruir o dogma maniqueu a partir da alma como primeira consideração (cogito cf. tríade ser-vida-intelecto); atribui-Ihe natureza intermediária entre sensíveis e inteligíveis e livre determinação de si pela atividade de valorar os bens que a cerca. Consequentemente, a alma tem a missão de julgar os valores das naturezas apreendidas e organizá-las internamente segundo a via de percepção própria: sensível ou inteligível. Ora, esse procedimento é volitivo, então Agostinho descobre a absoluta indeterminação interior da vontade como único elemento do móbile humano e convoca a teoria das "partes da alma", segundo a tradição neoplatônica, para redefinir o 
alcance da parte intelectiva da alma a partir de sua experiência de falibilidade 
pessoal. Ao final, o esforço de reconhecer ontologicamente a alma como incorporeamente una - momento em que pecado é definido como estado negativo de ser -, deve considerar a cisão original e supra individual: "um involuntário instalado no seio do voluntário". Reintroduzse a questão "das duas almas" no plano geral da filosofia do bispo, em registro notoriamente distinto: interioridade e confissão.

Palavras-chave: metafísica, ontologia, moral, alma, subjetividade. 


\section{ABSTRACT}

FUJISAKA, D. Augustine and the Manichaeans: analysis from "two souls". 2014. 228 p. Thesis (Master) - Faculdade de Filosofia, Letras e Ciências Sociais. Departamento de Filosofia, Universidade de São Paulo, São Paulo, 2014.

The aim of this thesis is to demonstrate how Augustine reappoints the Manichaean issue of "two souls" to the field of human interiority, as associate life and soul as goods perceived by the intellect and therefore irreducibly real (cogito). Thus, the soul can judge the value of natures and organize them internally according to each way of perception of soul: sensible or intelligible. In the first part, we seek to understand the question through the analysis of third book of the Confessions, paragraphs 1.1 to 6.12. We proceed in double interest, interrelating two notions of sin: 1) The nature of being or not beingdefectus of individual will- and 2) as misery -heritage impotence deja lá in order to aim possibilities of assimilation and refusal of the Manichaean gnosis. In addition, we explore how Augustine faces the problem of the existence of evil soul in analysis of the treatise of 392, About the Two Souls (De duabus animabus) - second part of our work. In this work, the Hipponate seeks to demolish all gnose through doctrine of "two souls". Thus, the soul is the first consideration -cogito: being, life and intellection comprenhended only by the intellect- by which intuitive definitions of will and sin are allowed. After discovering the absolute indeterminacy of the will as the only element of human mobile, Augustine proceed to adapt the theory of "parts of the soul", according to the Neoplatonic tradition, and sharply modify the role of intellectual part of the soul- in context of his own experience of fallibility. At the end, the effort to recognize the soul as ontologically non-corporeal and undivided - moment in which $\sin$ is 
defined as denial of being (defectus) - should also consider the original and supra-individual cleavage: "an involuntary installed within 
the volunteer". It was reintroduced the question "of two souls" in the philosophy of the bishop in distinguished register: interiority and confession.

Key Words: metaphysics, ontology, moral, soul, subjectivity. 
SUMÁRIO

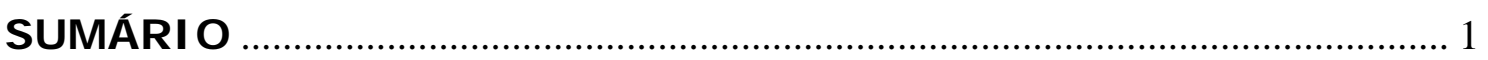

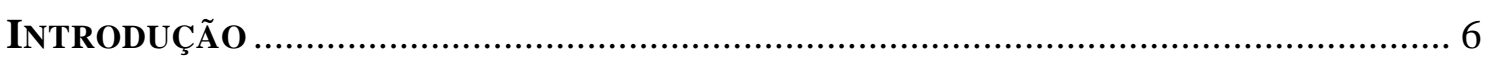

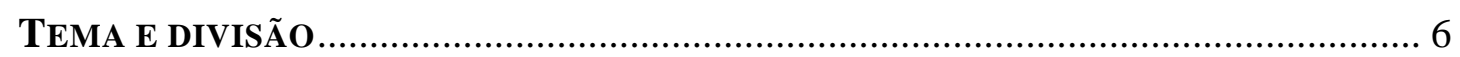

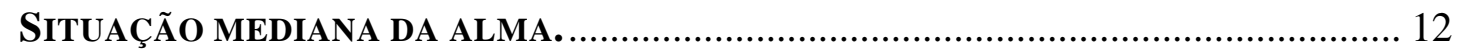

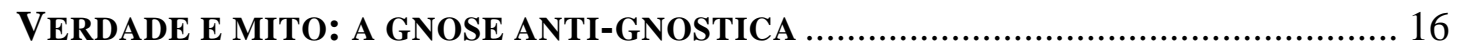

PARTE I - A QUESTÃo MANIQUEIA NAS CONFISSÕ ES III .......................................... 23



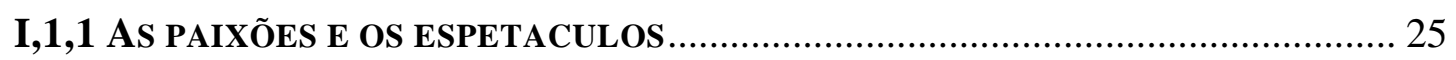

I,1,2 A FALSA E VERDADEIRA MISERICORDIA ................................................... 33

I,1,3 A EXORTAÇÃo AO CONTROLE DAS PAIXÕES PELO DISCURSO RACIONAL

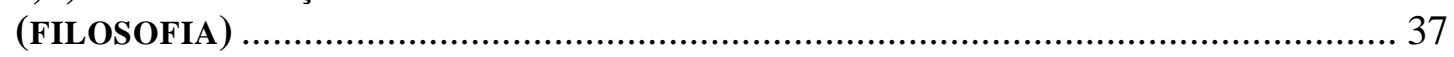

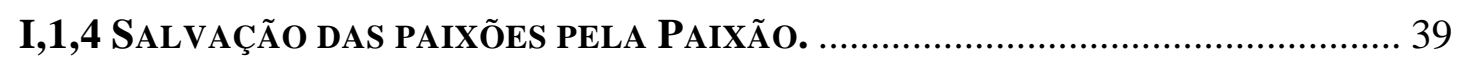

I,2 A QUEDA E O DELIRIO DOS LOQUAZES (IN HOMINES DELIRANTES LOQUACES).

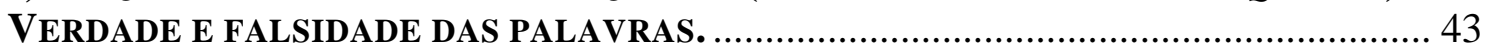

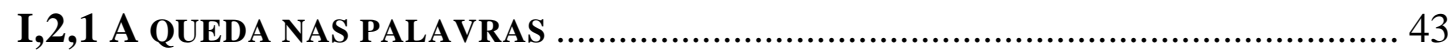

I,2,2 VERDADE E PALAVRAS SUPERADAS (TRANSGREDI) ................................... 47

I,2,3 A FALACIA DE MISTURAS DE SILABAS (CRISTOLOGIA) ............................... 48

I,2,4 Presença e distancia de Deus (Soteriologia) ................................... 55

SEMELHANÇA: INTERIORIDADE E ANTERIORIDADE DO AMOR. ........................ 57

EXTERIORIDADE E DESSEMELHANÇA (REGIO DISSIMILITUDINIS) ..................... 61

I,3 A GNOSE RESISTE: SOBRE AS DUAS ALMAS (DISCURSO RACIONAL) ..................... 72

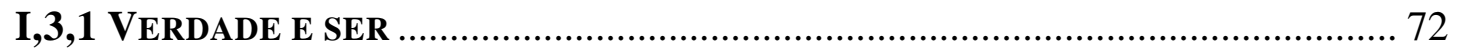

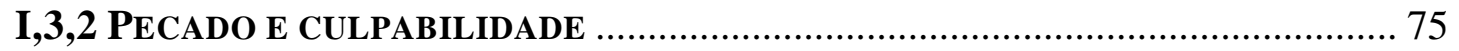

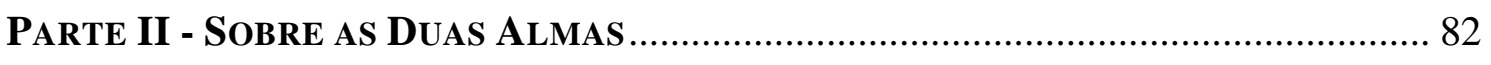



II,1,1 UM TRATADO ENTRE A MISERIA HUMANA E A MISERICORDIA DIVINA...... 88

II,1,2 A ALMA COMO PRIMEIRA CONSIDERAÇÃO OU PRIMEIRO DESLOCAMENTO

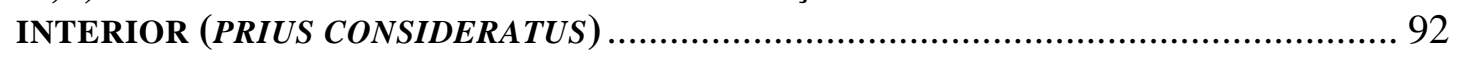

II,1,3 ENTRE A OPINIÃO DE DOUTISSIMOS E A DIALETICA................................... 96

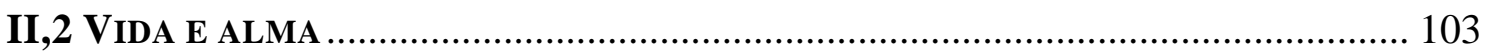

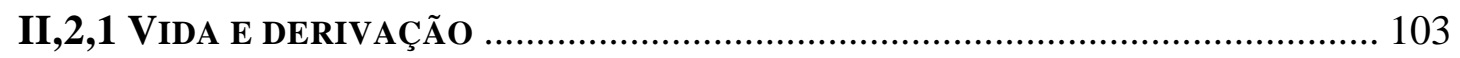

II,2,2 ARGUMENTO DECISIVO: SUBSTANCIA INCORPORAL ............................... 105

II,2,3 A UTILIDADE E ENGANO DA REPRESENTAÇÃO SENSIVEL (ET BONI

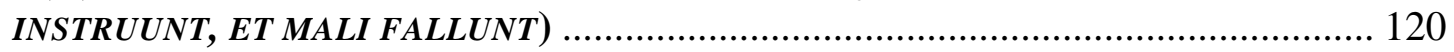

II,2,4 A VIDA E COMPREENDIDA PELO INTELECTO. A ALMA E UMA SUBSTANCIA INCORPORAL (COGITO) 


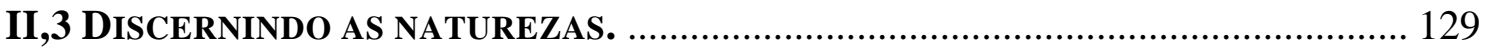

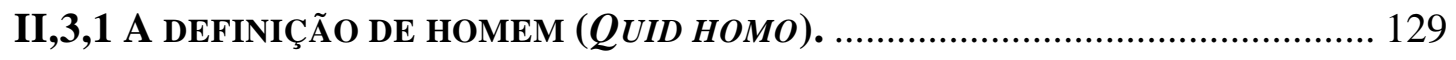

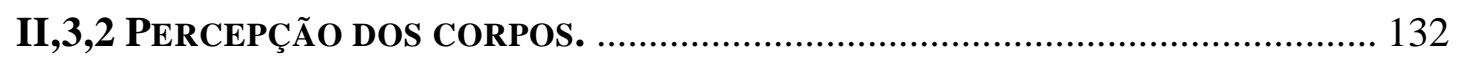

II,3,3 DEFECTIBILIDADE E CONSERVAÇÃO DOS SERES ...................................... 134

II,3,4 A VIDA DOS PEQUENOS E SUPERIOR AOS CORPOS DOS ASTROS................. 136

II,3,5 OS VICIOS DA ALMA SÃO SUPERIORES A LUZ SENSIVEL ............................ 140

II,3,6 IRREDUTIBILIDADE DO SER PELO SEU OPOSTO....................................... 142

II,4 - ONTOLOgIA E ETICA. ALCANCE DE dUAS DEFINIÇÕES ................................. 149

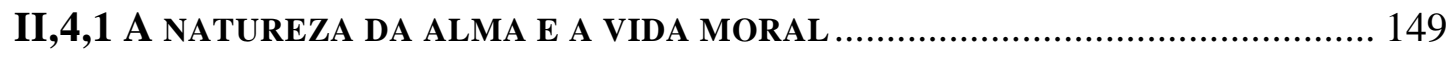

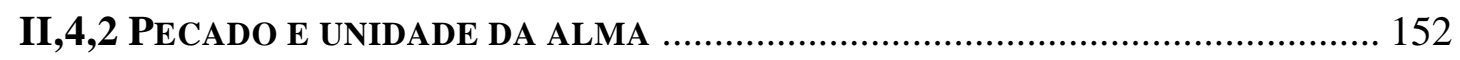

II,4,3 COGITO AMPLIADO: SER, VIVER-QUERER, PENSAR. ............................... 156

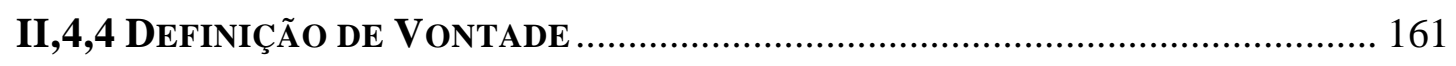



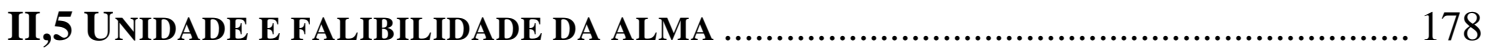

II,5,1 DOIS GENEROS DE COISAS BOAS, INFERIOR E SUPERIOR, NA MESMA ALMA

II,5,2 APROPRIAÇÃo dAS “PARTES dA ALMA” POR AgostinHo. ...................... 186

II,5,3 PECAdo: HABITo (CONSUETUDO) E IMITAÇÃo. .......................................... 192

II,5,4 ADMIRAVEL TENSÃO ENTRE ASCENSÃO DE HABITO. ............................... 199

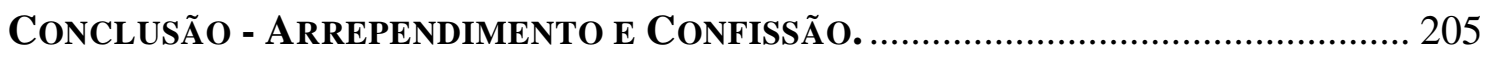

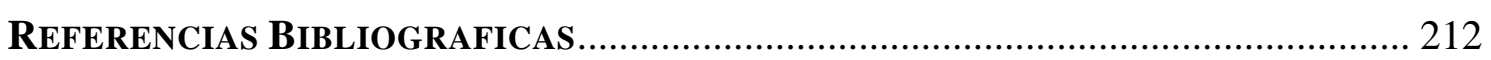




\title{
Lista de abreviações
}

\author{
Algumas Obras de Agostinho ${ }^{1}$ : \\ beata v. de beata vita (386) \\ c. acad. contra academicos (386) \\ c. Adim. contra Adimantum (393/4) \\ c. adv. leg. contra adversarium legis et prophetarum (420) \\ c. don. contra partem Donati post gesta (411) \\ c. ep. fund. contra epistulam quam vocant 'fundamenti' (396) \\ c. ep. Parm. contra epistulam Parmeniani (400) \\ c. ep. pel. contra duas epistulas pelagianorum (420/1) \\ c. Faust. contra Faustum manichaeum (397/9) \\ c. Fel. acta contra Felicem manichaeum (404) \\ c. Fort. acta contra Forunatum manichaeum (392) \\ c. Iul. contra Iulianum (421/2) \\ c. Iul. imp. opus imperfectum contra Iulianum (429/30) \\ c. mend. contra mendacium ad Consentium (420) \\ c. Sec. contra Secundinum manichaeum (398) \\ civ. de civitate dei (413 426/7) \\ dial. de dialectica (387) \\ disc. chr. de disciplina christiana (398) \\ div. qu. de diversis quaestionibus LXXXIII (388/96) \\ div. qu. Simp. de diversis quaestionibus VII ad Simplicianum (396) \\ doctr. chr. de doctrina christiana (396 [completed 427]) \\ duab. an. de duabus animabus contra manichaeos (391/2) \\ en. Ps. enarrationes in Psalmos (392/417) \\ ep. (epp.) epistula (epistulae) (386 430) \\ de secta donatistarum (405) \\ exp. prop. $\quad$ expositio quarumdam propositionum ex epistola ad Romanos (394)
Rom. \\ f. et symb. de fide et symbolo (393) \\ Gal. exp. epistolae ad Galatas expositio (394/5) \\ Gn. c. man. de Genesi contra manichaeos (388/90) \\ Gn. litt. de Genesi ad litteram (401 15) \\ Gn. litt. imp. de Genesi ad litteram imperfectus liber (393/4; 426/7) \\ haer. de haeresibus (428) \\ imm. an. de immortalitate animae (387) \\ Io. ep. tr. tractatus in Iohannis epistulam ad Parthos (406/7) \\ Io. ev. tr. tractatus in evangelium Iohannis (406 21?)
}

${ }^{1}$ Cf. O'Donnell, J.J. Augustine's Confessions: Oxford; New York: Clarendon Press, 1992. Em parênteses a datação da obra. Nossa lista é o recolhimento das principais obras por ordem alfabética a fim de facilitar a busca do leitor. Não se pretende fazer das obras listadas o corpus da nossa dissertação. 


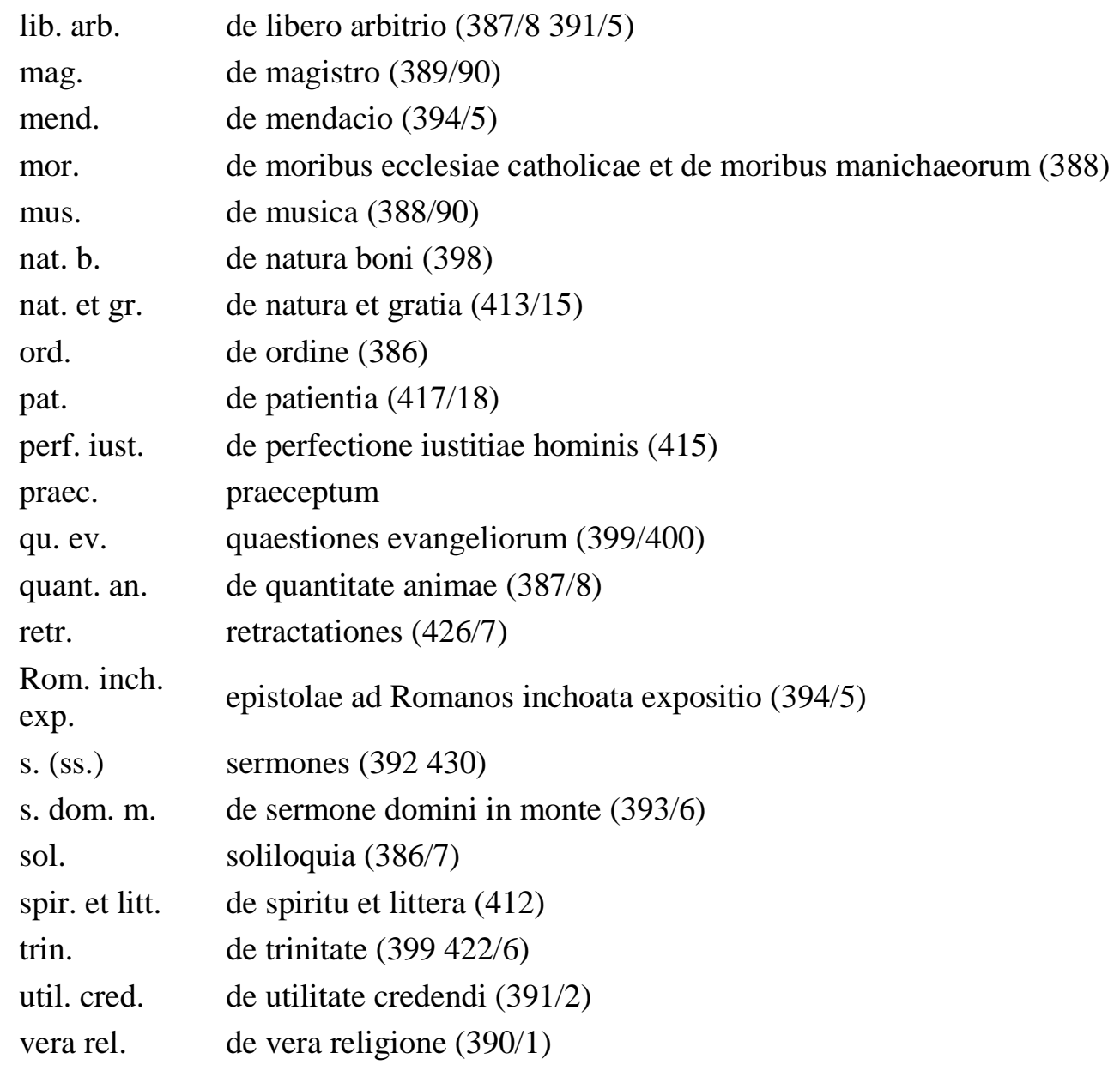

Notas de Tradução e fONTE das obras de AGosti nHO

Os textos latinos foram tomados do site www.augustinus.it , Patrologia latina organizada por J. P. Migne. Città Nuova Editrice and Nuova Biblioteca Agostiniana

Quando não houver indicação de tradução ao português, trata-se de nossa autoria. Na obra que exigiu maior volume de tradução, De duabus animabus, utilizamos em cotejo a tradução de Roland Teske, Augustine, Saint. The Manichean Debate, 2006; e R. Jolivet, Oeuvres de Saint Augustin. Six traités anti-manichéens, 1961. 
UNIVERSIDADE DE SÃO PAULO

FACULDADE DE FILOSOFIA, LETRAS E CIÊNCIAS HUMANAS DEPARTAMENTO DE FILOSOFIA

PROGRAMA DE PÓS-GRADUAÇÃO EM FILOSOFIA 


\section{NTRODUÇÃO}

\section{TEMA E DIVISÃo}

A dissertação pretende examinar o tratamento filosófico que Agostinho confere ao maniqueísmo. Para tal, situaremos a discussão no embate contra o dogma gnóstico das "duas almas", que, como veremos nas Confissões, não é questão pequena no pensamento do hiponense.

É necessário identificar, de partida, algumas hipóteses condutoras de nossa leitura. Já foi dito que a passagem de Agostinho pela doutrina gnóstica possibilitou, no corpus de suas obras antimaniqueias, a elaboração de uma "ontologia inteiramente renovada"2, na medida em que deu ocasião para uma profunda alteração do corporalismo para a descoberta da interioridade como espírito, de natureza incorpórea. ${ }^{3}$ A passagem do maniqueísmo ao neoplatonismo ofereceria ao hiponense, como primeira conversão, "uma nova visão de mundo" ${ }^{4}$, ou seja, passagem do corporalismo às realidades espirituais.

Mas, a nosso ver, a questão maniqueia na filosofia agostiniana não pode ser reduzida como oposição ao corporalismo. Nosso exame parte de outro lugar: o hiponense, já na apropriação dos instrumentos neoplatônicos ${ }^{5}$, é um cristão que pretende "batizar" o neoplatonismo e, nesse sentido, o exame do livro III das Confissões

\footnotetext{
2 cf. O. du Roy. L'intelligence de la foi en la Trinité selon Saint Augustin: genèse de sa théologie trinitaire jusqu'en 391., 1966, p.82

${ }^{3}$ Cf. G. Lanfonte, apud Madec, G. Notes sur l'intelligence augustinienne de la foi, In: Révue des. Études Augustiniennes 17, 1971. L'experience des erreurs manichéenes a eu pour effet que la Sagesse chrétienne d'Augustin devait, pour ansi dire à priore, présenter des elements d'ontologie. p. 125.

${ }^{4}$ O. du Roy. L'intelligence de la foi en la Trinité selon Saint Augustin..., 1966 ; p. 82

5 Consultar Madec. Le Platonisme dans la conversion. In: Petites Études Augustiniennes. Paris: Institut d'études augustiniennes, 1994, p. 53
} 
mostrará que há na passagem do maniqueísmo ao cristianismo neoplatônico mais do que uma "ontologia totalmente renovada"6 , de modo que o problema que cerca a adesão à gnose maniqueia não deve ser reduzido à questão da natureza do mundo. Prova disso, como veremos, é que Agostinho levará para esse novo modelo ontológico, em que a alma se descobre de natureza inteligível e intermediária entre os sensíveis e os inteligíveis imutáveis no tempo, os antigos problemas levantados pela gnose. Esta reintrodução da agenda maniqueia no modelo ontológico neoplatônico causará profunda alteração dessa renovada ontologia, mas já superada filosofia.

Ensejamos, pois, ampliar nossa compreensão acerca da questão gnóstica e pensar algo mais do que apenas "elementos de ontologia", de modo que nossa hipótese inicial considera que há dois tratamentos da questão do mal, ou pecado para Agostinho. Um deles, uma resposta ao mito dogmático maniqueu, trata pecado como "uma declividade negativa" ou momento negativo do ser individual (defectus da vontade), como diria P. Ricoeur ${ }^{7}$. Outro tratamento considera pecado como miséria (miser), uma doença da alma que acabará por lançar as bases da doutrina do pecado original. E isso é importante: o pecado original não está na origem da metafísica moral de Agostinho, mas é fruto da experiência fracassada: um momento misterioso da atividade humana que não pode ser analisável, apenas compreendida na narrativa pessoal. É a distância entre a pura indeterminação da vontade do eu quero sem constrangimento (nulo $\operatorname{cogente}^{8}$ ) e a insuficiência do eu não posso querer completamente. A

\footnotetext{
${ }^{6}$ Ver nota 3

7 Ricoeur, Paul. O "pecado original": estudo de significação, In O conflito das interpretações. Ensaios de hermenêutica. Porto: Res Editora, 1989, p. 270

${ }^{8} \mathrm{cf}$. duab. an. Consulte nossa análise em parte II.
} 
esse último, J. L. Marion refere como impotência de "querer querer"9 que, segundo Agostinho nas Confissões VIII, é base da falibilidade da condição humana em "poder querer". Com efeito, mais do que "poder de querer", é impotência de "querer querer" que desvela o mistério monstruoso (monstrum cf. conf. VIII) da insuficiência humana e da "alienação da vontade a ela mesma". ${ }^{10}$

São, portanto, dois tratamentos dado ao pecado desenvolvidos em momentos distintos para problemas diferentes. Por isso, é comum nos estudos agostinianos referir ao segundo momento, pecado como miséria, como um desenvolvimento posterior de maturidade, consolidado definitivamente nos escritos contra Pelágio. É possível, no entanto, amenizar essa leitura disjuntiva, salientando a forte presença conceitual de miséria e misericórdia já num texto essencialmente antimaniqueu de 392, Sobre as Duas Almas, portanto vinte anos antes do primeiro tratado anti-pelagiano ${ }^{11}$, o que significa que o tratamento de pecado como miséria, resultado trágico do pecado original, teria sua origem bem antes da oposição de Pelágio contra a doutrina agostiniana da graça. Ademais, o tratado Sobre as Duas Almas antecede as Confissões em quase dez anos, o que aponta para o fato de que a impotência da vontade de "querer querer" (livro VIII das Confissões) já estava dada, ainda que não plenamente desenvolvida, na polêmica maniqueia. Evidentemente, o segundo momento será, em nossa dissertação, apenas anunciado e pressuposto no estilo confessional, que já se mostrava no tratado de 392. Assim, não avançamos para a análise cerrada de textos que descrevem a vontade cindida, visto que implicaria a análise de obras da maturidade de Agostinho, bem como o exame das ricas páginas

\footnotetext{
${ }^{9}$ cf. J. L. Marion.Au Lieu de Soi. L'approche de saint Augustin. 2008, p. 235 10 idem, p. 239

11 cf. P. Ricoeur, opera cit., p. 274. Refere-se ao De peccatorum meritis et remissione et de baptismo parvulorum ad Marcellinum (411/12)
} 
do momento de sua conversão descritas em Confissões VIII. O intuito é apenas identificar o quanto os dois tratamentos de pecado estão imbricados e devem ser entendidos mais como continuidade do que ruptura.

Há, defendemos, mais a pensar nos textos contra os maniqueus do que declividade do ser. Em suma, a tragicidade do pecado como elemento inerente à miséria é carregada desde sua experiência gnóstica mais profunda (o que lhe valeria críticas futuras de Juliano de Eclano, que Ihe acusaria de nunca ter superado o efeito trágico da gnose). Pretendemos a partir do tratado Sobre as Duas Almas (De duabus animabus, 391), descrever como Agostinho assume a noção neoplatônica sobre a natureza da alma, retendo o que conceitualmente lhe interessa, como, por exemplo, a interioridade e a substância incorporal da alma; mas, quando da inclusão do pecado e da falibilidade da vontade da alma, o aparato neoplatônico, possivelmente recolhido em Plotino, encontrará seu limite na teoria da progressão da alma intelectiva à segunda hipóstase, a Inteligência (Nous), exigindo adequação aos conceitos intuitivos de pecado e vontade. Essa é uma obra privilegiada para traçar os aspectos da natureza da alma, ao passo que desvela a condição finita do homem no quadro particular do pensamento ético daquele que quer conhecer tanto a si mesmo quanto o que lhe transcende. Poderemos encontrar o hiponense "lutando" contra a gnose e desenvolvendo novos conceitos para antigos problemas.

Ao final, pecado não será bem um conceito, mas um mistério: presença paradoxal de "substância negativa" (defectus), vazia, que exigirá alterações profundas no modo como Agostinho compreende o homem e suas potências de alcance à verdade/virtude. Não se trata apenas de um conceito privativo, cuja presença afasta a ofensa do conceito; pecado é fatidicamente um mistério a ser 
considerado na missão temporal de discernir e valorar naturezas apreendidas $^{12}$ (percipi) e que obriga o filósofo a produzir conceito ${ }^{13}$. Esse dado permitirá explorar tanto as marcas profundas ${ }^{14}$ que os escritos contra os maniqueus imprimiram no filósofo, quanto reconhecer o manejo perspicaz de sua tradição filosófica.

\section{VISÃo}

Dividiremos este trabalho em duas partes: a primeira situa a polêmica sobre "as duas almas" a partir das Confissões, III,1-7, passando por trechos do livro V e VII, com o objetivo de levantar a referida questão maniqueia em plano geral e explorar o pano de fundo da gnose que atraíra o jovem estudante de retórica em Cartago. Em seguida, analisamos em pormenor o tratado de 392, Sobre as Duas Almas, a fim de verificar como Agostinho recoloca a angústia interior da gnose em novos moldes conceituais.

Propomos quatro movimentos para análise de Sobre as Duas Almas:

1) Vida e alma: I,1 - II,2

2) Discernindo as naturezas. III,3- VI,8

3) Ontologia e moral: VII,9 - XII,18

4) Unidade e falibilidade da alma: XIII,19 - XV,23

\footnotetext{
12 cf. Gn. c. man. II,9,12

13 a experiência do pecado antecede o conceito; cf. Ricoeur, consultar nossa seção 'Verdade e mito'.

14 cf. Markus, Robert. "It is undoubtedly linked with his conversion from Manicheism, perhaps, of all the conversions which have been traced in his career, the one which brought with it the most profound upheaval and was to have the most momentous consequences in his spiritual life" Markus, R. A. Conversion and Disenchantment In: Augustine's Spiritual Career. 1989. p. 6. Também consultar Oort, Van, Augustine and manichaeism: new discoveries, new perspectives, in: Verbum et Ecclesia, 27(2), 2006; Oort, Van. Manichaeism: its sources and influences on western christianity, In: Verbum et Ecclesia 30(2), 2009.
} 
Pretendemos demonstrar nesse tratado como o filósofo reconduz estrategicamente a discussão para o campo da interioridade humana, associando vida e alma como bens compreendidos pelo intelecto e irredutivelmente verdadeiros (1) para que, em seguida, a alma possa passar a julgar os valores das naturezas apreendidas e, assim, organizá-las internamente (2). Agostinho procura derruir o dogma maniqueu a partir de definições intuitivas de vontade e pecado (3); e ao descobrir a absoluta indeterminação da vontade como único elemento do móbile humano, convoca a teoria das "partes da alma", segundo a tradição neoplatônica, para pensar o pecado como cisão da mente intelectiva (4). Ao final, o esforço de reconhecer ontologicamente a alma como una - momento em que pecado é definido como estado negativo de ser - deve considerar a cisão original e supra individual: "um involuntário instalado no seio do voluntário"15. Finalmente, cria-se oportunidade para pensar a relação possível entre verdade e confissão.

Antes de analisarmos as Confissões e Sobre as Duas Almas, com o intuito de esclarecer nossa leitura, apresentamos dois estudos propedêuticos ao exame da questão das "duas almas" em Agostinho: primeiramente, referimos o comentário Sobre o Genêsis contra os Maniqueus II,9,12 (388/9) com o propósito de situar, como ponto de partida de nossa dissertação, a alma criada e ordenada em situação mediana entre coisas sensíveis e inteligíveis. Em seguida, recorremos ao estudo de Paul Ricoeur ${ }^{16}$, a fim de fundamentar nossa proposta de

15 Ricoeur, P. O "pecado original": estudo de significação, In O conflito das interpretações. Ensaios de hermenêutica. Porto: Res Editora, 1989, p. 281

16 Ricoeur, P. O "pecado original": estudo de significação, In O conflito das interpretações. Ensaios de hermenêutica. Porto: Res Editora, 1989 ; Ricoeur, Paul. Le Conflit Des Interprétations: Essais D'herméneutique. Paris: Éditions du Seuil, 1969. ; Consultar também Ricoeur, Paul. O mal: um desafio à Filosofia e à Teologia. Campinas: Papirus, 1988; Ricoeur, Paul. Finitude et culpabilité. V.1 (I'homme faillible). V.2 (la symbolique du mal). Paris: Aubier, 1960 
leitura que parte do entendimento de dois tratamentos para a noção de pecado.

\title{
SI TUAÇÃO MEDI ANA DA ALMA.
}

\author{
CF. COMENTÁRIO DE GÊNESIS CONTRA MANIQUEUS II ,9, 12
}

De partida, a alma, em situação mediana, atribui um peso moral do qual não se pode escapar ${ }^{17}$. Vejamos, pois, um texto inserido no corpus das obras antimaniqueias, datada do mesmo período do tratado, Comentário sobre o Gênesis contra os Maniqueus (388/9). Ali, a alma, única responsável por realizar os movimentos em direção aos objetos sensíveis e inteligíveis, deve dirigir-se ao puro ser, sem, contudo, deixar de utilizar (uti) as coisas corporais:

Mas a árvore da vida plantada no meio (medio) ${ }^{18}$ do paraíso significa aquela sabedoria pela qual é preciso que a alma entenda que está ordenada em situação intermediária (meditullio) entre as coisas, pois, embora tenha subordinada a si toda a natureza corpórea, a alma entende que tem acima de si a natureza de Deus. Portanto, que a alma não se desvie para a direita, atribuindo a si o que não é, nem para a esquerda,

17 E. Gilson ressalta que a questão ética permanece unida à metafísica de Agostinho. Cf: "Assim, a antropologia e a psicologia de santo Agostinho estão suspensas por uma moral que lhes confere a razão de suas características essenciais. Numa doutrina desse gênero, uma vez que o homem é antes de tudo sua alma, algumas operações poderão ser atribuídas propriamente ao homem, ainda que somente a alma tome parte nelas." Gilson, E. Introdução a Santo Agostinho. 2007, p. 99.

${ }^{18}$ Madec traduz por "mitan". In "Diagramme Augustinienne" Volume 25, Issue 1/2, August 1985; apud A. I. Bouton-Toubolic B. A. 50, p. 71. Infelizmente não tivemos acesso ao artigo. Mas a autora indica que a tradução precisa de dupla orientação: por um lado uma orientação ontológica onde Deus está colocado em oposição à natureza do corpo; por outro, uma "declinação" ética em que a alma desequilibrase e sai do seu eixo quando identifica-se aos corpos (esquerda) ou a Deus (direita). No parágrafo, ainda há uma terceira imagem que reforça as representações conceituais da primeira árvore. A "árvore do conhecimento do bem e do mal", pelo qual Agostinho confere dinamismo à natureza da alma. Para Bouton-Touboulic a imagem representa "o movimento que alma deve tomar para preservar sua integridade ordenada (integritas ordinata)" idem, p. 72. 
menosprezando por negligência o que é. Com efeito, esta é a árvore plantada no meio do paraíso ${ }^{19}$.

Na verdade, trata-se de manejar o campo de ação moral em estreita relação com o pensamento ${ }^{20}$. A vida moral se dá pelo movimento da alma, cuja vontade necessariamente livre dirige o homem sem qualquer constrangimento, tanto em direção a isso (inteligível) quanto àquilo (sensível). Não há sustentação moral sem imediata relação do agente com os objetos de desejo.

Na exegese alegórica que Agostinho faz do Gênesis, a "árvore da vida no meio do paraíso" significa que "a alma está ordenada no meio das coisas", o que significa que a tarefa essencial da natureza humana parte de sua condição intermediária na ordem hierárquica das coisas criadas. O lugar naturalmente ordenado da alma, desde a criação, é no meio da criação (ordinata in meditullio), de onde surge o desafio ou a responsabilidade de não se menosprezar, rebaixando-se às coisas sensíveis, pois a alma não é de natureza corpórea; nem se arrogar mais inteligível do que realmente é, porque a intimidade com Deus não resulta em que o homem seja Deus $^{21}$.

Então, "não ir à esquerda negligenciando o que se é (quod est)" significa não tomar as representações sensíveis como fator de naturalização e verdade. E "não atribuir a si o que não é" significa não arrogar que a alma partilhe da mesma natureza de Deus. Com

\footnotetext{
19 Gn. c. man. II, 9, 12. Lignum autem vitae plantatum in medio paradisi, sapientiam illam significat, qua oportet ut intellegat anima, in meditullio quodam rerum se esse ordinatam, ut quamvis subiectam sibi habeat omnem naturam corpoream, supra se tamen esse intellegat naturam Dei: et neque in dexteram declinet, sibi arrogando quod non est; neque ad sinistram, per neglegentiam contemnendo quod est: et hoc est lignum vitae plantatum in medio paradisi.

${ }^{20}$ A. I. Bouton-Touboulic comenta sobre esta passagem: "A ordem é inseparavelmente ontológica, noética e ética". In: B. A. 50; p. 71.

21 Consultar nossa análise da ambivalência agostiniana entre imanência e transcendência na análise do enunciado: "interior intimo meo". cf. conf. III, 6, 11.
} 
efeito, há uma justeza fina onde a alma deve se posicionar e, diferentemente de todos os outros seres, que não escolhem o lugar onde estão, pois é natural que se conformem à sua medida, ao homem é dada possibilidade de mobilidade "ontológica", o que por si estabelece um estatuto de liberdade de partida, visto que permanece sempre a opção de declinar-se do eixo da ordem natural.

Contra a gnose, Agostinho vai explorar principalmente a dinâmica dessa declinação, que não passa de uma falácia do espírito. Quando a alma "abandona o bem", alimenta-se do que é mutável como se o alimento fosse imutável. O problema, pois, não é o alimento sensível em si, mas a ilusão de que o sensível seja a própria nutrição espiritual. A crítica de Agostinho dirige-se para esse movimento enganoso no interior da alma, pelo qual se pretende que a imagem fantasiosa (phantasmata) seja o verdadeiro alimento, visto que o sofisma maniqueu transforma as justas representações sensíveis (fantasias) em desordenadas ilusões. O que pode parecer derruidora crítica aos sensíveis, é mais uma análise do engano ou do ato da alma enganar-se.

Nos textos que tratam da ascensão da alma a Deus, cujo trajeto parte do sensível ao inteligível, Agostinho enfatiza que os corpos podem e devem ser representados no espírito, para então reconduzir à fonte a qual todas as coisas estão submetidas (subiectum). No contexto do combate contra os maniqueus, a ênfase é outra, pois busca-se compreender o que parece ser um dado bruto espantoso, uma doença (miris morbis) que gera um curto-circuito no itinerário ascensional; um engano que perturbou esse justo acordo (convenientia) entre a alma e coisas criadas (inteligíveis e sensíveis). Ao expor a falácia maniqueia, Agostinho procura pelo centro produtivo do engano e não encontrará outra coisa senão a própria alma. É preciso, primeiramente, buscar identificar qual seja a 
"natureza da alma em sua justa ordenação" (ordinatas integritas naturae) $)^{22}$.

Não se trata somente de engano da capacidade raciocinante, no sentido de uma confusão mental de ordem exclusivamente dialético-racional. Há uma "fruição" fora do lugar, pois, ao tomar para si o que é próprio ao divino, o homem cai em soberba (superbia), adentrando numa difícil condição. Ora, se a soberba é alimentada, há um interesse do homem que emerge de um ganho momentâneo ${ }^{23}$.

A condição de autoposicionamento de si em relação à ordem é uma tarefa relacional, ou seja, a alma deve "aprender por experiência", percebendo e internalizando as coisas que a rodeia.

E no momento deste pecado (superbia) a pena que segue é que a alma deve aprender por experiência qual a diferença entre o bem que abandonou e o mal em que caiu. ${ }^{24}$

E se cabe ao homem "aprender pela 'experiência' (experiendo discit) a distância entre inteligíveis e sensíveis", há ao menos dois passos importantes: primeiro, a alma deve discernir seus modos de percepção; segundo, a alma deve aprender as razões pela qual ajuíza e qualifica as representações.

A missão humana é conhecer a si mesma. Após a queda, tem de partida o desafio de "entender que a alma está ordenada no

\footnotetext{
${ }^{22}$ Cf. Gn. c. man. II, 9, 12.

${ }^{23}$ Consultar Gilson, Etienne. O Espírito da Filosofia Medieval. 2006. O estudioso reconhece em Agostinho a mesma esteira socrática do oráculo de Delfos. "Para se conhecer é necessário pôr-se em seu devido lugar (...) no fundo este é o verdadeiro sentido do preceito de Sócrates", p. 286.

${ }^{24}$ Gn. c. man. II, 9, 12. Et cum hoc eius peccatum poena fuerit consecuta, experiendo discit quid intersit inter bonum quod deseruit, et malum in quod cecidit.
} 
meio das coisas" ${ }^{25}$, entre sensíveis e inteligíveis. Essa situação intermediária é o cenário pelo qual a alma deve exercitar sua capacidade raciocinante para a reconciliação com o Bem abandonado. Entenda-se que há dois modos de movimentar-se para os sensíveis. Um é justo e compõe a trilha de ascensão a Deus; o outro é falacioso. Assim, "cair no mal" não é o mesmo que mover-se para baixo, pois o baixo não é idêntico ao mal. O que é mal é ser absorvido pela ilusão de que o baixo seja alto. Ora, Agostinho terá que contrapor tal confusão mental à perspicácia (acies mentes) maniqueia.

Como desvencilhar-se de tal engodo? Como, por fim, executar a tarefa de reconstituição de uma natureza capaz de julgar e ordenar internamente as criaturas e, assim, reordenar-se em acordo (convenientia) com o Criador? Buscará a homologia estoica ${ }^{26}$ como a concórdia da razão reflexiva à natureza, onde a vida seja necessariamente uma vida de deveres ordenados segundo o cálculo da razão? E o pecado, que insiste em "militar contra nós mesmos"? Como entendê-lo? São questões que serão colocadas por Agostinho ao longo da polêmica contra os maniqueus. O projeto não é pequeno, como bem indica o teor dos questionamentos. E nem poderia ser, se - que se almeja é combater as questões levantadas pela gigantomaquia gnóstica. Agostinho enfrentará as dificuldades tanto com inteligência quanto com honestidade: marcas de um filósofo que se viu constantemente envolvido pelos problemas que investigou.

\section{VERDADE E MITO: A GNOSE ANTI-GNÓSTI CA}

Foi talvez Paul Ricoeur quem melhor traçou as linhas de forças da questão da milícia interior no contexto do mito da origem

\footnotetext{
${ }^{25}$ idem, qua oportet ut intellegat anima, in meditullio quodam rerum se esse ordinatam

${ }^{26}$ cf. Cícero, De finibus III, 20; de vera relig. XXXIX, 72.
} 
do pecado. O hermeneuta propõe um "estudo de significação", cuja intenção é elucidar as "motivações profundas" da elaboração de um conceito por trás de um mito, o pecado original no caso. Diz que "refletir sobre a significação é, de certa maneira, desfazer o conceito, decompor as suas motivações por uma espécie de análise intencional" ${ }^{27}$. Mas o que parece ser um procedimento derruidor, "desfazer o conceito", é também reencontrar os motivos que dirigiram a produção de sentido e significado; em uma palavra, abrir o símbolo que antecede a racionalização do mito. Assim a narrativa da ficção mítica descola da história, mas não basta, diz Ricoeur: "excluir o mito da história, é preciso retirar dele a verdade que não é histórica"28. Agostinho, assim, teria sido o primeiro a elaborar o conceito do pecado original, ao passo que teria compreendido e mantido a riqueza da verdade mítica do mal dejá lá ${ }^{29}$, reposicionando a questão à partir da releitura paulina do mito adâmico (cf. apóstolo Paulo, Romanos 5,12 e $\left.19^{30}\right)$. Em outras palavras, trata-se de explorar a verdade para além dos limites da linguagem racional e reconduzir-se à verdade contida no símbolo mítico e escondida como "linguagem cifrada", isto é, "inexprimível em linguagem direta e clara". Assim, o mito aparece como linguagem "mais profunda" que dá acesso à experiência primordial da condição humana. Ao recusar a linguagem especulativa, nos deparamos, diz Ricoeur, com os mitos que são: "não uma falsa explicação por meio de imagens e fábulas, mas uma narrativa tradicional, que se refere aos eventos que

\footnotetext{
27 cf. Paul Ricoeur. O "pecado original": estudo de significação, In O conflito das interpretações. Ensaios de hermenêutica. Porto: Res Editora, 1989, p. 265

28 idem, p. 279

${ }^{29}$ idem, idem

30 idem, p. 271. Visto que Ricoeur não menciona o texto de onde retira, I. Bochet sugere que ele tenha referido ao pecc. mer. I,9 9.'"Hoc autem apostolicum testimonium, in quo ait: Per unum hominem peccatum intravit in mundum et per peccatum mors (Rom. 5,12)". Ricoeur analisa a exegese de Agostinho quando da interpretação da preposição grega interpretada "por um homem" que também poderia ser "mediante um homem".
} 
aconteceram no início do tempo" ${ }^{31}$. O pecado original conteria o mistério da linguagem cifrada, como alternativa de expressão da linguagem para o acesso de significações da iniquidade praticada. É uma tentativa de alcançar o ponto em que a linguagem explicativa não consegue chegar.

Por isso, para o hermeneuta, torna-se importante voltar aos símbolos dos mitos da origem do mundo e da origem do pecado. No caso do mito gnóstico-dogmático, trata-se de expor o "pseudo-saber" para elucidar o "verdadeiro símbolo". Ricoeur toma como hipótese de trabalho que o pecado original tenha dupla caracterização no pensamento do hiponense. Por um lado, o conceito seria "antignóstico" nos seus fundamentos metafísicos; por outro lado, diz: "a teologia do mal deixou-se conduzir para o próprio terreno da gnose e deste modo elaborou uma conceptualização comparável à sua". Portanto, uma "gnose anti-gnóstica".

Agostinho teria assumido o "mesmo impulso da gnose" ao tomar a questão do mal como saber. Assim, o pecado original, como mito racionalizado da origem do mal, é saber e conceito e, diria $\mathrm{P}$. Ricoeur: é quase gnose (como se fosse gnose), ou gnose antignóstica. É gnose, na medida em que aceita a agenda gnóstica e conceitua (racionaliza) o mito da origem do mal como pecado original, mantendo o enunciado de um mal dejá lá compatilhado e universal (cf. Rm. 5 todos pecaram em Adão - omnes pecauerum in Adam $^{32}$ ), mas anti-gnóstico nas formulações de fundo metafísico, a saber, "o mal não tem natureza, o mal não é qualquer coisa; o mal não é matéria, não é substância, não é mundo. Ele não é em si, é nosso".

\footnotetext{
31 idem, p. 279

${ }^{32}$ Consultar nota anterior
} 
Seguir toda argumentação de Ricoeur pelos textos agostinianos dos quais o estudioso retira suas interpretações seria abrir uma investigação que ultrapassaria o objetivo dessa dissertação. É suficiente, para nosso interesse, marcar dois tratamentos da questão do mal no contexto da significação do mito do pecado original. I. Bochet traça uma linha que divide o artigo em dois momentos: ético e trágico. O primeiro se dá no quadro dos textos anti-maniqueus, enquanto que o último nos textos contra Pelágio ${ }^{33}$.

No sentido ético, podemos entender a questão a partir de motivações de fundo "apologéticas - para combater a gnose", pelo qual a teologia cristã teria sido levada a "inscrever-se sob o modo de pensamento gnóstico". A fim de compreender melhor tal proposição, central no artigo, Ricoeur explicita e sintetiza a questão do mal como exterioridade:

Se a gnose é gnose, isto é, conhecimento, saber, ciência, é porque, fundamentalmente - como o têm mostrado Jonas, Quispel, Puech e outros -, o mal é para ela uma realidade quase física, que investe de fora contra o homem; o mal está fora; é corpo, é coisa, é mundo, e a alma foi encarcerada dentro; esta exterioridade do mal fornece imediatamente o esquema de uma qualquer coisa, de uma substância que infecta por contágio ${ }^{34}$.

A formulação cosmológica e exterior do mal, segundo a gnose, faz do exterior uma potência capaz de tomar a força a alma interior. O mal chega em nós como substância, como se fosse algo físico, para englobar a alma. Admitindo, ademais, a existência do dogma das duas almas, o mal chega não é mais o mundo de fora, e sim a própria alma, no seu polo oposto, a alma má. Nesse quadro, “o

\footnotetext{
${ }^{33}$ cf. Isabelle Bochet. Augustin dans la pensée de Paul Ricoeur. Paris: 2003, p.17

${ }^{34}$ P. Ricoeur, opera cit., p. 280
} 
mal é a própria mundaneidade do mundo"35 e mundo é a alma. Se, pois, o mal é espelhado na realidade anímica de uma alma má, entende-se melhor o que seja "pecado como destino interiorizado", ou como referimos, uma tragicidade anímica.

Por aí, percebe-se que, talvez, I. Bochet é rígida demais na demarcação do artigo de Ricoeur, pois o que o fenomenólogo pretende é encontrar na tragicidade do mito gnóstico o pano de fundo da discussão pelagiana. Afirma: “A intenção do pseudo-conceito do pecado original é então: incorporar à descrição da vontade má, tal como ela é elaborada contra Mani e a gnose, o tema de uma quasenatureza do mal"36.

No sentido trágico do pecado original, importa descobrir o sentido de "original". A primeira resposta de Agostinho tinha conduzido a origem do pecado para a vontade e para dentro do homem. Mas essa é uma resposta provisória, pois uma nova formulação é requerida quando se trata de relacionar pecado e culpabilidade emergidas da experiência moral fracassada.

A vontade define o pecado, mas não explica a sua origem. A segunda resposta aparentemente retrocede a primeira: o pecado parece ter uma origem involuntária, ou melhor, uma origem voluntária compartilhada, portanto, supra individual. Desse modo, o conceito do pecado original está fundado num paradoxo misterioso e, agora, “o mal é uma espécie de involuntário no seio do próprio voluntário". 37

A tragicidade do pecado na gnose é o inverso do movimento de começo individual, "o inverso da declividade ${ }^{38}$ individual". Busca-

\footnotetext{
35 idem, p. 269

36 idem, idem

${ }^{37}$ Ricoeur, opera cit., p. 281.

${ }^{38}$ Ricoeur, opera cit., p. 274. "tara herdada por nascimento"
} 
se compreender a perpetuação do pecado, uma continuação do defectus da vontade como um tipo de "tara hereditária" transmitida a todo o gênero humano por um primeiro homem, ancestral de todos os homens: "cada um de nós também o encontra (mal), encontra-o dejá lá, em si mesmo e fora de si, antes de si. Para toda a consciência que desperta para a assunção de responsabilidade, o mal é dejá lá".

Destarte, Ricoeur identifica Agostinho como o responsável pela conceptualização do pecado original como mito racionalizado. Mas, segundo o hermeneuta, a crítica ao procedimento racional do filósofo cristão não esconde a genialidade do criador do conceito. Reconhece-se que o bispo teria entendido melhor o mistério do pecado do que Pelágio. Teria compreendido muito bem o que há de espantoso nessa miséria-doença (miris morbis), decifrando-a na linguagem emotiva da confissão. Refere que a "miséria antecede a consciência" e, portanto, não pode ser analisável exclusivamente pelas faltas particulares nem pelo pensamento especulativo.

Ricoeur conclui que no mistério do pecado reside, sem dúvida, "o mistério último do pecado: nós começamos o mal, por nós entra o mal no mundo, mas começamos o mal apenas a partir de um mal dejá lá, de que o nosso nascimento é o símbolo impenetrável"39

Dados os dois planos, eticidade e tragicidade, que envolvem a noção de pecado, partamos para a leitura do Sobre as Duas Almas, a fim de esclarecer o modo pelo qual Agostinho maneja, talvez pela primeira vez, os dois planos do problema da relação entre pecado e culpabilidade. Importa esclarecer que não pretendemos buscar geneticamente a origem do conceito do pecado original. Trata-se de perceber e explicitar as linhas de forças da questão e recuar para o

${ }^{39}$ Ricoeur, opera cit., p. 281 
contexto e experiência que o próprio autor ofereceu e associou ao conceito.

\section{Outra imbricação: ontologia e moral}

Paralelamente à imbricação entre tragicidade e eticidade, Agostinho nos permite reconhecer em seu pensamento outra relação essencial: ontologia e ética. É necessário, pois, ainda ressaltar como orientação de leitura à dissertação que, apesar de recusarmos a leitura da obra antimaniqueia reduzida à ontologia, não significa que não demos atenção à passagem ontológica (natureza da alma, cogito, representação, verdade). Com efeito, na segunda parte do texto, na análise do tratado Sobre as Duas Almas, o leitor perceberá nosso esforço em inserir no embate tradicionalmente moral (sobre a vontade) a discussão metafísica sobre a natureza da alma, revisando os antecedentes da tradição filosófica de Agostinho que nos permitirão avançar para questões basilares de seu pensamento, ao mesmo tempo em que pudemos acompanhar o gênio do nosso filósofo no tratamento argumentativo-dialético que, como polemista, dedicou ao tratado. 


\section{Parte I - A questão mani Queia nas Confissões I I I}

Iniciamos, assim, nossa leitura do livro III das Confissões com duplo interesse, buscando as nuances da imbricação de duas noções de pecado: como ser (ou ausência de ser, defectus da vontade individual) e como miséria (herança de uma impotência). Veremos na parte final como vontade, pecado e culpabilidade desembocam no problema da existência da alma má, reconduzindo à análise do tratado de 392.

\section{I,1 O CONTEXTO PASSI ONAL DA QUEDA ( ITAQUE I NCI DI)}

A partir do livro III das Confissões, Agostinho descreve a formação intelectual ${ }^{40}$ como jovem estudante de retórica em Cartágo. Ocorre o primeiro encontro com a seita gnóstico-cristã, logo após a impactante leitura do protréptico de Cícero ${ }^{41}$. O trecho que marca a sua adesão à seita gnóstico-cristã encontra-se em Confissões III, 6, 10 e estende-se até $V, 14,25$. A descrição minuciosa circunscrita nesse longo trecho do livro é proporcional ao próprio tempo em que Agostinho havia permanecido intimamente vinculado ao dogma de Mani. São nove anos os quais Agostinho retoma a fim de expor os motivos e desejos que cercaram tal peregrinação.

Em III,6,11: "E assim, caí no meio de homens orgulhosamente delirantes". ${ }^{42}$ Essa pequena sentença pode indicar dois momentos que divisam o livro. O primeiro refere-se aos motivos que atraíram Agostinho ao maniqueísmo. O conectivo "assim" (itaque) remete ao contexto anterior e deixa claro que a queda no

\footnotetext{
40 Consultar Breyfrogle, T In: PAFFENROTH, Kim, \& KENNEDY, Robert Peter. A Reader's Companion to Augustine's Confessions. 2003.

${ }^{41}$ cf. conf. III,5,9

${ }^{42} \mathrm{cf}$. conf. III,6,10 Itaque incidi in homines superbe delirantes.
} 
meio dos maniqueus (incidi in homines superbe delirantes) não é acidental no seu itinerário de formação intelectual-espiritual. ${ }^{43}$ Há, pois, pelo menos duas possibilidades de contextualização: a primeira, aquela imediatamente ao texto anterior (parágrafo 9), refere-se a soberba que impede a adesão à fé cristã, na medida em que o estilo simples das Escrituras é preterido pelo estilo grandioso de Cícero. Esta opção tem a tendência de reduzir toda a questão da adesão ao maniqueísmo à exegese e estilo dos volumes escriturísticos. A segunda possibilidade de retomada contextual parece mais plausível, pois retrocede à descrição da tensão entre paixão e compaixão desde as primeiras linhas do livro III, passando pelo desejo das ficções teatrais (cap. I-II), pelo ambiente competitivo dos estudos liberais (cap. III) e pelo conteúdo protréptico-filosófico do Hortênsio de Cícero $^{44}$ (cap. IV).

Se tomarmos por base a questão maniquéia como eixo temático do livro III, é possível analisar o livro a partir da seguinte divisão:

- Contexto da queda 3.1.1 - 3.5.9

o As paixões e os espetáculos (miséria-misericórdia)

o O protréptico de Cícero, Hortênsio. Primeria exortação à cura da alma pela filosofia

o O "nome de Cristo". Conjunção entre afeto (misericórdia) e sabedoria

\footnotetext{
43 Utilizamos o termo espiritual em sentido de completude, ampliando o usual termo "formação intelectual", a fim de aprofundar o ser do humano, que abarca e supera sua intelectualidade. Para uma análise dos 'atrativos' do maniqueísmo ao jovem Agostinho, bem como as causas de afastamento, consulte-se CAMBRONNE, Patrice. Augustin et l'Église : Jalons d'un itinéraire Notes de lecture (Confessions, III-IV, 10). In: Vita Latina, $\mathrm{N}^{\circ} 115,1989$. pp. 22-36

${ }^{44}$ Cf. conf. III, 1-5
} 
- A queda. 3.05.09-3.7.11:

o 3.6.10 A queda nas palavras, e necessidade de superálas

o 3.6.11. Os degraus da "descensão".

o Anterioridade do amor. (interior intimo meo)

o Regio dissimilitudinis

o Caso das ficções.

- 3.6.12. (V,10,18). Ontologia e experiência moral.

o Verdade e ser (vere quod est et privatio boni).

o Pecado e culpabilidade. Confissões V,10,18.

o Apresentação do dogma gnóstico das duas almas.

Desde já, no contexto da 'queda maniquéia', a divisão enseja afastar da análise certa interpretação do período maniqueu de Agostinho como questão reduzida à ontologia. $\mathrm{Na}$ verdade, o problema do mal e sua posterior solução (privatio boni) são precedidos de um laborioso desenvolvimento de Agostinho acerca da possibilidade de distinção entre verdade e falsidade a partir dos dados da exterioridade. Sabe-se bem que tal temática aparece de modo muito evidente em diálogos da juventude como, por exemplo, nos Contra Acadêmicos ou Solilóquios. E nas Confissões III, a nosso ver, Agostinho tem de novo o tema da verdade e falsidade colocado a sua frente, mas em outro registro.

\section{I,1,1 As pai Xões e os eSPetáculos}


Agostinho explicita suas paixões, emergidas dos espetáculos, e as contrapõem à pura paixão encarnada, a misericórdia de Cristo. Elabora-se a reflexão a partir da problematização do binômio miséria e misericórdia, onde a misericórdia ou compaixão humana é apresentada como elemento de semelhança e distância da pura misericórdia, só encontrada no nome de Cristo.

Agostinho começa pela crítica das misérias suscitadas pelos espetáculos teatrais ${ }^{45}$ ao afirmar: "Arrebatavam-me os espetáculos teatrais, cheios de imagens das minhas misérias e de alimento próprio para o fogo das minhas paixões" ${ }^{46}$. O hiponense traça um corte preciso para aprofundar o entendimento entre as relações possíveis do sofrimento e os fundamentos éticos dos móbiles das ações humanas. De início, note-se que a imagem é medicinal e a associação da miséria e misericórdia com doença, loucura, ou saúde não é acidental; ao contrário, oferecerá importante chave de leitura das linhas que seguem. As paixões emergidas dos espetáculos teatrais, longe de reverterem em misericórdia e compaixão ao sofredor, apenas produzem deletério prazer por dor e sofrimento da cena teatral, inflamando ainda mais o fogo de sua miséria, ou doença da alma. A busca pela compreensão dessa doença leva Agostinho a descrever o deleite pela dor encenada. Agostinho questiona-se:

\footnotetext{
45 O'Donnell enfatiza o tema da curiositas como o tema central do livro e principal fator da queda no maniqueísmo. Apesar da palavra estar ausente no texto, insiste na recorrência no de vera relig. 52. Contrariamente, G. Madec e Theiler (apud O'Donnell) seguem a temática do impacto sobre as paixões e emoções: “G-M, Theiler P.u.A. 60, and BA all attempt to situate this text in the tradition of ancient discussions of the emotional impact of the theater. (...)". A que O'Donnel objecta: "Dominant is surely his own notion of the connection to curiositas".

In: http://www9.georgetown.edu. Aqui, livro III, seguimos a temática do impacto emocional do teatro, no entanto, parece ser plausível a relação dos espetáculos teatrais e a curiositas, principalmente no livro VI quando do episódio da atração de Alípio aos "espetáculos dos gladiadores" cf. conf. VI,8,13

46 conf. III,2,2. Rapiebant me spectacula theatrica plena imaginibus miseriarum mearum et fomitibus ignis mei.
} 
Mas por que quer o homem condoer-se ao ver cenas dolorosas e trágicas, quando de modo algum deseja suportá-las? Todavia, o espectador anseia por sentir esse sofrimento, que, afinal, para ele constitui um prazer. Que é isto senão uma miserável insanidade (miserabilis insania) ? ${ }^{47}$

Há um deslocamento de perspectiva. Os espetáculos e as tragédias que Agostinho assistia quando jovem não eram tão surpreendentes quanto aquele cenário que emergia de sua interioridade. A vil fruição da dor que não se move em auxílio ao sofredor expõe a clausura do prazer que não transcende a si mesmo. Assim, o prazer pelo prazer não comove a alma do espectador a auxiliar o sofredor, apenas interessa-lhe a fruição de assistir fora o que não quer ver dentro (introspecção)

Em A Verdadeira Religião (391), Agostinho descreve o "espetáculo eterno" como o recolhimento na alma de todas as coisas por recordação, a fim de admoestar o espectador a contemplar a "primeira beleza perdida" para a qual tudo converge em harmonia (convenientia) prazeirosa:

Aquele que se deleita com o espetáculo da verdade imutável, não se atira de cima de seu corpo, isto é, das coisas visíveis, para conhecer coisas temporais e interiores. O que há pois que não possa servir de recordação à alma daquela primeira beleza perdida, quando até seus próprios vícios o fazem ${ }^{48}$

Surpreendentemente, até a história dos vícios servirá de tinta ao artista que coordena (ordinata) seus eventos como

\footnotetext{
${ }^{47}$ conf. III,2,2 Quid est, quod ibi homo vult dolere cum spectat luctuosa et tragica, quae tamen pati ipse nollet? Et tamen pati vult ex eis dolorem spectator et dolor ipse est voluptas eius. Quid est nisi miserabilis insania?

${ }_{48}$ vera relig. XXXIX, 71-72 Quisquis aeterno spectaculo incommutabilis veritatis adhaerescit, non per fastigium huius corporis, id est per hos oculos praecipitatur, ut temporalia et inferiora cognoscat. 39. 72. Quid igitur restat, unde non possit anima recordari primam pulchritudinem quam reliquit, quando de ipsis suis vitiis potest?
} 
pinceladas impressas na alma ${ }^{49}$, pois se alguém "questionar acerca do prazer, nada encontrará a não ser a convenientia" ${ }^{50}$. Não se trata do prazer pelo prazer, mas do prazer como transcendência, como passagem por via contemplativa e confessional, afinal o contraste entre a beleza imanente à alma e o vício dos prazeres revelam a diferença do "não sou idêntico a suma convenitentia" (Confitere te non esse quod ipsa est). O termo "convenientia", traduzido frequentemente por harmonia, remete a ordem segundo a razão, um acordo de todas as coisas que convergem para a completude de tudo que existe. De sabor evidentemente estóico, o enunciado deixa claro, porém, que a "suma convenientia" não se identifica à razão; de fato, o ser que está em perfeito acordo consigo mesmo não se encerra na razão, mas está para além dela. Nesse contexto, a transcendência da alma não se dá por identidade, mas por atestação da diferença:

Reconheça portanto o que seja a summa convenientia. Não vás para fora, mas voltes para dentro ; no interior do homem habita a verdade; e se encontras a mutabilidade na tua natureza, transcenda a ti mesmo. $\mathrm{E}$ em transcendendo a ti mesmo, não se esqueça que transcendes a alma que raciocicina ${ }^{51}$.

Desse modo, a história pessoal do vício (vitium) expõe uma realidade interior mutável, quando comparada à verdade imutável inerente à alma.

Quase dez anos depois, Agostinho dá continuidade ao projeto de ascensão por revisão interior do próprio prazer. Analisando o prazer do espectador do teatro (histrionis), ele diz :

${ }^{49} \mathrm{Cf}$. vera relg. XXXIV, 72 Ita per hanc summus ille artifex opera sua in unum finem decoris ordinata contexuit.

50 Idem. Quaere in corporis voluptate quid teneat, nihil aliud invenies quam convenientiam: nam si resistentia pariant dolorem, convenientia pariunt voluptatem.

${ }^{51}$ Idem. Recognosce igitur quae sit summa convenientia. Noli foras ire, in teipsum redi; in interiore homine habitat veritas; et si tuam naturam mutabilem inveneris, transcende et teipsum. Sed memento cum te transcendis, ratiocinantem animam te transcendere 
Daí o meu amor pelas dores, mas não pelos que me atingissem profundamente, pois eu não desejava suportar as dores que amava contemplar; as ficções que eu via e ouvia tocavam-me a superfície da alma ${ }^{52}$.

Tal crítica aos desejos provindos das ficções parece passar menos pela exclusão das paixões (ataraxia) do que pela incapacidade de intensificá-las na interioridade. A mera fruição do espectador impedia a introspeção de um sofrimento ainda maior e mais real. Não por acaso, aquelas tragédias humanas encenadas apenas "tocavam superficialmente" (raderent superficie) o problema do seu sofrimento, tangenciando e ocultando as profundezas do sofrimento pessoal de quem apenas assistia ao sofrimento alheio. A superficialidade narrada da juventude é recuperada na alma, pelo exercício confessional, a fim de penetrar na interioridade desse evento. O cenário interior que Agostinho quer ver e retratar nas Confissões parece ser, desde o início, um projeto de intensificação passional. Note-se também, assim como sugere Breyfogle ${ }^{53}$, que Agostinho, ao tecer a crítica à superficialidade do espectador, almeja despertar o espírito do seu leitor, dentre os quais muitos maniqueus ${ }^{54}$, pelas descrições de suas dores e amores que, por exemplo, se intensificarão no episódio do luto pelo amigo ${ }^{55}$, como estratégia literária de criar credibilidade e empatia (por testemunho e atestação) ${ }^{56}$ com o seu leitor.

Sem entrar na questão da comunicação dos conteúdos internos de uma consciência a outra, importa notar que Agostinho

\footnotetext{
52 conf. III,2,4 Et inde erant dolorum amores, non quibus altius penetrarer (non enim amabam talia perpeti, qualia spectare) sed quibus auditis et fictis tamquam in superficie raderer. Tradução Maria J.L. Amarante

${ }^{53}$ Breyfogle, T. In: PAFFENROTH\& KENNEDY. A Reader's Companion to Augustine's Confessions. 2003. p. 38

54 Sobre a audiência maniquéia das Confissões, consulte-se KOTZÉ, Annemaré. Augustine's Confessions: Communicative Purpose and Audience.; Boston: Brill, 2004

${ }^{55}$ conf. IV

${ }^{56}$ Sobre o tema, consulte-se Pierron. Témoignage dans les Confessions de Saint Augustin, 1995
} 
vislumbra dentro de si um cenário composto pelas paixões que são ainda mais intensas do que aquelas suscitadas pelas ficções cênicas. Pode-se dizer, então, que desse ponto de vista, Agostinho enseja, nas Confissões, radicalizar a experiência passional ao seu limite

Até aqui, cumpre-se bem aquilo que fora anunciado no prólogo do livro II. O bispo anunciava o projeto de elevação da alma por um itinerário retrospectivo, de "retorno ao passado pelos antigos caminhos", a fim de experimentar o amargor de suas errâncias e consequente "recomposição da dispersão para a unidade de si". Essa "unidade de si" passará pelo resgate dos desejos, puros e impuros, a fim de permitir ao filósofo o aprofundamento das relações de diferença e identidade com seu criador, ou seja, passará necessariamente pela sua dispersão. O desejo pela dor como fruição da carne é assim sintoma de uma doença, enquanto que a misericórdia é o puro desejo que dignifica a presença do lamento. A cura das paixões da alma, no entanto, consiste menos em procurar as causas de um prazer corporal do que exortar a alma por uma tomada de consciência da diferença entre unidade e dispersão, doença e saúde, miséria e misericórdia. Ou seja, não se trata de um procedimento diagnóstico que visa curar a si mesmo, mas de, pela consciência do pecado como fruto de determinação espiritual, poder aprofundar o conhecimento de si pela análise de seus "amores por dores". Para Agostinho, a cura é um horizonte, um encontro com a pura misericórdia.

A estratégia que passa necessariamente pela experiência pessoal, análise histórica da vida do errante, retira o pecado dos bastidores da tragicidade para uma atividade que coloca lado a lado verdade e pecado ${ }^{57}$. Mas o caminho do peregrino confessante é

${ }^{57}$ Consultar vera relig. 37-39 
árdua, pois o pecado dos pecados, a soberba (superbia), opera justamente no ocultamento da consciência a si mesma. Agostinho, no entanto, não desespera: não grita, nem se cala; vê no exercício confessional uma possibilidade produtiva, da qual é possível almejar a elevação.

Trata-se de buscar a superação de uma condição que faz o homem "andar em círculos com o peso da morte e o testemunho do pecado". ${ }^{58}$ A confissão abre essa circularidade fechada do pecado e espera encontrar a presença divina outrora obnubilada no "espetáculo eterno" da narrativa confessional:

Aquele que se alimenta interiormente com a palavra de Deus não procura no deserto desta vida o prazer(...) Aquele que se deleita com o espetáculo eterno da verdade imutável não se precipita de cima de seu corpo, isto é, das coisas visíveis pelos olhos do corpo para conhecer coisas temporais e inferiores. ${ }^{59}$

No livro III das Confissões, Agostinho parece montar aos olhos do espectador, ao seu leitor e a si mesmo, cenários que admoestam tanto os olhos carnais quanto espirituais. O espetáculo temporal é compreendido e interiorizado como memória do pecado, isto é, passado presentificado e confessado à luz do espetáculo eterno.

O espetáculo terreno expõe a circularidade do pecado e revela uma presença velada:

Sempre estavas presente em tua severa misericórdia, entremeando de amargos desgostos os meus prazeres

\footnotetext{
${ }^{58}$ conf. 1,1,1 et homo circumferens mortalitatem suam, circumferens testimonium peccati sui

${ }^{59}$ vera relig.XXXVIII, 71 Quamobrem quisquis intus verbo Dei pascitur, non quaerit in ista eremo voluptatem. ... Quisquis aeterno spectaculo incommutabilis veritatis adhaerescit, non per fastigium huius corporis, id est per hos oculos praecipitatur, ut temporalia et inferiora cognoscat.
} 
ilícitos, a fim de que eu aprendesse a procurar a alegria sem ofender-te ${ }^{60}$

Agostinho perscruta a história da ausência de si a si mesmo para descobrir a perene presença da misericórdia. Obviamente, busca-se pela primazia do espiritual ou inteligível, o que não resulta na exclusão da percepção corporal; ao contrário, a proposta é justamente traçar a história dos espetáculos, ou melhor, a história do espectador em relação aos espetáculos encenados. Na linguagem do confessante: "A recordação é amarga, mas espero sentir tua doçura, doçura que não engana, feliz e segura" ${ }^{61} \mathrm{O}$ retorno a si, ainda que exponha os "antigos caminhos" que o distanciaram da origem, pode ao final ser exatamente o novo caminho para uma revelação salutar: "tu estas sempre presente", pois a semelhança não se perdeu naqueles caminhos. O espetáculo do pecado como história marcada pela espantosa doença da alma (miris morbis), quando interiorizada e presentificada, transforma em um mirabolante "espetáculo eterno".

Insistimos, então, que a falácia maniquéia a ser exposta não é tanto a do outro; mas a sua mesma. Por diversas vezes, Agostinho declara-se, quanto ao maniqueísmo, ser enganado e enganador ${ }^{62}$, de modo que não há coerção que Ihe seja exterior. Resulta, que ser enganado é, ao mesmo tempo, enganar, e o polemista que confessa verá a si mesmo no horizonte da batalha. O campo de batalha do polemista cristão não é, pois, a doutrina, mas a interioridade daquele incidiu na falsidade.

A seguir, a misericórdia verdadeira é identificada ao nome de Cristo. Se antes, Agostinho opõe misericórdia divina, a pura

60 conf. II,1,1 Nam tu semper aderas misericorditer saeviens, et amarissimis aspergens offensionibus omnes illicitas iucunditates meas. Tradução de M. J. L . Amarante

${ }^{61}$ conf. $11,1,1$ recolens vias meas nequissimas in amaritudine recogitationis meae, ut tu dulcescas mihi, dulcedo non fallax, dulcedo felix et secura.

${ }^{62}$ Cf. conf. IV, 1,1 
paixão, à fruição do prazer cênico; agora, no encontro com o Hortênsio de Cícero, busca identificar a sabedoria à misericórdia verdadeira.

\section{I,1,2 A fALSA E VERDADEIRA MI SERICÓRDIA}

Mas ao sofrimento próprio chamamos ordinariamente de miséria; e à compaixão das dores alheias, misericórdia. Que misericórdia é essa dos assuntos fictícios e cênicos, se não induz o espectador a prestar auxílio, mas somente o convida à angústia e a aplaudir ao dramaturgo na proporção da dor que experimenta? ${ }^{63}$.

Primeiro, uma questão de precisão de vocabulário. Miséria, aqui, refere-se ao sofrimento, no uso comum da palavra, e misericórdia alude à compaixão ao outro quando em sofrimento. Agostinho, então, espanta-se com o próprio prazer na miséria dos personagens fictícios: “Mas, afinal, que compaixão (misericórdia) é essa das cenas fictícias do teatro?"64. A resposta é dada por contraste: Deus se compadece dos homens de um modo mais verdadeiro:

Essa misericórdia é mais verdadeira (verior misericordia). E a dor, neste caso, não tira dela prazer algum. Se é louvável aquele que por dever de caridade sofre com a miséria alheia, quem é genuinamente misericordioso preferiria que não houvesse motivo para sofrimento. (...). Portanto, Senhor meu Deus, que

63 conf. III,2,2 quamquam, cum ipse patitur, miseria, cum aliis compatitur, misericordia dici solet. Sed qualis tandem misericordia in rebus fictis et scenicis? Non enim ad subveniendum provocatur auditor, sed tantum ad dolendum invitatur et actori earum imaginum amplius favet, cum amplius dolet. Infelizmente, a tradução de ... não percebe o jogo entre miséria e misericórdia, saúde e loucura e traduz misericórdia por compaixão. Nossa tradução mantém o vocábulo miséria e misericórdia.

${ }^{64}$ conf. III,2,2 Sed qualis tandem misericordia in rebus fictis et scenicis? conf. $1 \mathrm{II}, 2,2$. 
amas os homens, tua compaixão é muito mais profunda e mais pura que a nossa, pois não está eivada de dor alguma. E quem estaria à altura de tal missão? ${ }^{65}$

A exposição da falsa misericórdia gerada pelas ficções teatrais serve para apresentar um caminho de salvação dos desejos que por sua vez possa conjugar o par sofrimento e misericórdia em substituição ao par sofrimento e prazer.

Ao contrário da misericórdia humana, a verdadeira misericórdia não busca o sofrimento como fonte de fruição e deleite, mas aceita o sofrimento na medida em que entende que o reconhecimento de sua presença é indicativo da ausência divina. A misericórdia verdadeira em oposição à misericórdia humana faz mais do que expor a diferença entre divino e humano; de fato, introduz o tema das paixões ao alcance do filósofo.

A introdução das paixões como elemento de ascensão do pensamento, segundo E. Auerbach, é típica do período. Em seu ensaio, Gloria Passionis, o filólogo localiza na antiguidade tardo antiga o momento da elaboração da noção de passio como "sofrimento e enlevo dialeticamente relacionados". ${ }^{66}$ Introduz-se, então, um sentido

${ }^{65}$ conf. III,2,3 Haec certe verior misericordia, sed non in ea delectat dolor. Nam etsi approbatur officio caritatis qui dolet miserum, mallet tamen utique non esse quod doleret, qui germanitus misericors est... Nonnullus itaque dolor approbandus, nullus amandus est. Hoc enim tu, Domine Deus, qui animas amas, longe alteque purius quam nos et incorruptibilius misereris, quod nullo dolore sauciaris. Et ad haec quis idoneus?

${ }^{66}$ Auerbach, em seu ensaio Gloria passionis, estuda a evolução do termo "paixão" desde o pathos grego, passando pelas mística cristã/pagã latina, até a noção moderna conforme o conhecemos. Na antiguidade, o termo pathos conotava ou neutralidade ética, no caso de Aristóteles, ou negatividade, no caso dos estoicos, que opunham as paixões agitadas à tranquilidade da razão. Até a antiguidade tardia, traduzia-se o termo passio em sentido estoico, assumindo frequentemente a sinonímia de pertubatio. No entanto, Agostinho, assim como Ambrósio, distancia-se energicamente da doutrina estoica de passio (cf. civ. Dei IX,4 ss). Auerbach enfatiza a diferença entre os autores cristãos do período tardo antigo e as filosofias que os antecederam: "Os autores cristãos não opunham às passiones a tranquilidade do sábio, mas a submissão à injustiça - sua intenção não era a de fugir ao mundo a fim de evitar os sofrimentos e as paixões." (p.79). Então, o retiro cristão do mundo não visa fugir do mundo como se pudesse, na ausência do mundo 
totalmente novo ao pathos antigo, pois sofrimento e fervor não se atêm como elementos distintos, mas estão dialeticamente relacionados: "o amor de Deus, que O levou a tomar para Si os sofrimentos dos homens, é, ele próprio, um motus animi icomensurável e ilimitado"67.

Este dado é de grande importância para entender o que Agostinho está fazendo nas Confissões, pois se o hiponense recusara o choro que nascia do prazer eticamente estéril das cenas teatrais ${ }^{68}$, não negará adiante a misericórdia verdadeira, cuja dignidade reabilitará a legitimidade das paixões humanas na elevação do homem a Deus. Se o primeiro movimento recusava o prazer do choro provocado pelo ator, o segundo acolhe a compaixão e misericórdia ao próximo, a fim de fornecer à lamentação novo estatuto de dignidade ascensional.

A paixão é reposicionada como elemento restaurador de toda uma cadeia emotiva afetada pela errância. A paixão não é apenas um produto final de um remodelamento moral; de fato, ela é o meio pelo qual o peregrino abre caminho para o retorno rumo a

\footnotetext{
de perturbações, viver a tranquilidade perfeita da razão. Ao contrário, a perfeição, segundo Ambrósio, é alcançada somente por "aquele a quem a carne não pode fazer voltar da glória da paixão" (quem caro iam revocare non posset a gloria passionis). Fugir do mundo, assim, não é fugir das paixões do mundo, mas da injustiça praticada no mundo. A encarnação do Verbo é determinante nessa passada, visto que gloria passionis, para o período tardo antigo, é identificado ao "sofrimento glorioso" do Cristo encarnado: paixão que tanto sofre quanto enleva. Assim, segundo o autor, sofrimento e fervor estão conjugados dialeticamente: "o amor de Deus, que O levou a tomar para Si os sofrimentos dos homens, é, ele próprio, um motus animi incomensurável e ilimitado (p.81). Aproxima-se, então, da noção moderna de paixão como encantamento e sofrimento. (p.95). cf. Gloria Passionis In: AUERBACH, Erich. Ensaios de literatura ocidental. São Paulo: Editora 34, 2007. p. 77-95

67 idem, p. 81

68 Não se trata de uma crítica geral à dramaturgia. São conhecidas as diversas citações poéticas que Agostinho faz da Eneida de Virgilio nas Confissões, bem como abundantes referências à ficção poética nos Diálogos. De fato, em conf III, 6,11, como veremos, Agostinho a contrapõe a utilidade das fábulas segundo diversos graus de verdade e falsidade.
} 
casa (patria) ${ }^{69}$. Agostinho, assim, reconhece que é necessária certa afinidade com o sofrimento a fim de salvaguardar a misericórdia como paixão divina na qual o homem participa. Ora, tomar o sofrimento como elemento de ascensão à virtude e a Deus não é, certamente, uma agenda do sábio greco-romano ${ }^{70}$. Este rivalizava a insânia da alma à presença da razão, pois a razão seria, por si mesma, garantia de sanidade e cura das paixões ${ }^{71}$. Cícero, por exemplo, aposta no esforço da "meditação racional" (cogitatione) para sanar a alma das paixões pelo cultivo das virtudes

Com máxima atenção devemos perceber o seguinte: o tempo tem o poder de aplacar o sofrimento, mas a força da cura não está no passar do tempo e sim na meditação cotidiana (cogitatione diuturna) ${ }^{72}$

Diferentemente, Agostinho não opõe razão e paixão, nem espera que o tempo aplaque o sofrimento; na verdade, recupera o sofrimento (aegritudo) pela narrativa confessional para propor uma nova terapêutica. A terapêutica agostiniana, assim, não recusa o sofrimento, e, por isso, pode fazer o retorno amargo às memórias de sua dispersão ${ }^{73}$. E mesmo que tal amizade entre sofrimento e razão pudesse causar algum estranhamento ao ideal antigo do sábio, o estudante de retórica insistia na presença do sofrimento e da paixão pelo seu íntimo parentesco com a misericórdia divina. O caso do luto pelo amigo maniqueu, descrito no livro IV, é um exemplo dessa reabilitação dos afetos por intensificação e não por supressão das emoções pelo controle da razão.

\footnotetext{
${ }^{69}$ cf. conf. $111,6,11$

${ }^{70}$ vide nota anterior

${ }^{71}$ cf. Cícero, Tusculanas III,8. Consultar Menezes, A. A história do discurso sobre as paixões nas Tusculanas de Cícero. In: Cadernos Espinosanos XXIV, 2011

${ }^{72}$ Cícero, Tusculanas, III,74. apud Menezes, A. p. 103

${ }^{73}$ cf. conf. II,1,1
} 
Mas, se guardarmos o percurso narrativo, veremos Agostinho tributar à Cícero a primeira exortação à cura das paixões da alma por exortação à sabedoria e filosofia.

\section{I,1,3 A exortação AO CONTROLE dAS PAIXões Pelo DISCURSO RACI ONAL (FI LOSOFIA)}

O ciclo de formação de retórica levaria o estudante de Cartago ao protréptico de Cícero, Hortênsio ${ }^{74}$. Este livro, hoje perdido, fez a primeira exortação pela cura da alma pela razão, ou seja, por um controle das paixões por via filosófica. Agostinho testemunha sua importância: "O livro é uma exortação à filosofia e chama-se Hortênsio. Devo dizer que ele mudou os meus sentimentos e o modo de me dirigir a ti; ele transformou as minhas aspirações e desejos."75. Com efeito, aos dezenove anos, o jovem, exortado ao estudo da filosofia, diz: "principiava a levantar-me para voltar para Vós", de modo que seus sentimentos e desejos seriam transformados pela exortação ao amor à sabedoria, ou "filosofia em grego". Percebe-se bem que o protréptico cumpriu sua meta de elevação conforme o registro de A. A. Long:

O termo protréptico dificilmente pode ser traduzido por uma única palavra em inglês. Refere-se a um tipo de discurso exortativo ou de admoestação que, mesmo em forma de monólogo ou perguntas-respostas, é concebido para fazer as pessoas refletirem acerca de

\footnotetext{
74 Consultar B. Stock. Augustine's Inner Dialogue... p., 35-38; Madec, G. Le "Hortensius" ,1969, pp. 165-17

75 conf. III,4,7 Sed liber ille ipsius exhortationem continet ad philosophiam et vocatur Hortensius. Ille vero liber mutavit affectum meum et ad te ipsum, Domine, mutavit preces meas et vota ac desideria mea fecit alia. Trad. Maria J.L. Amarante
} 
suas convicções éticas e converter para uma mudança fundamental de perspectiva e comportamento. ${ }^{76}$

O estudo da filosofia, que exortava à saúde das paixões, é reconhecidamente "um princípio de elevação e condução a Deus" (et surgere coeperam, ut ad te redirem), visto que as vãs afeições carnais que haviam conduzido o jovem hiponense até então são contrapostas ao novo desejo de sabedoria da tradição filosóficohelenista: "um incrível ardor do coração" pela "Sabedoria imortal"77.

Trata-se, pois, de importante ponto de direcionamento do discurso como exercício de purificação moral ${ }^{78}$ :

Apenas me deleitava, naquela exortação, o fato de essas palavras me excitarem fortemente e acenderem em mim o desejo de amar, buscar, conquistar, reter e abraçar, não esta ou aquela seita, mas sim a mesma sabedoria $^{79}$.

Surge uma nova postura intelectual-espiritual do jovem, que - lança à tradição racional-discursiva e ao amor à sabedoria (filosofia) ${ }^{80}$. Sabe-se que, anos depois, o jovem retor se servirá desta postura crítica (époché) ${ }^{81}$ do sábio acadêmico, que, por sua vez, o ajudará no afastamento do maniqueísmo ${ }^{82}$, mas nesse momento, como jovem estudante em Cartago, o convite à filosofia, à maneira

\footnotetext{
${ }^{7676}$ A. A. Long comenta sobre o caráter exortativo do discurso do protréptico: "the term protreptic can scarcely be translated by a single english word. It refers to a type of exhortative or admonitory discourse, either in monologue or in question-and answer form, designed to make persons rethink their ethical beliefs and convert to a fundamental change of outlook and behaviour." Long, A. A. Epictetus: A Stoic and Socratic Guide to Life, 2002 p. 54

${ }_{78}$ conf. III, 4,7

${ }^{78} \mathrm{cf}$. Cambronne, P. Augustin et l'Eglise ..., p. 23

${ }^{79}$ conf. III, 4,8

${ }^{80}$ cf. Também, G. Catapano. La philosophia e i philosophi nelle Confessioni, pp. 9096

${ }^{81}$ Consultar nossa análise do prológo do duab. an.

82 cf. conf. V,14.25 Itaque Academicorum more, dubitans de omnibus atque inter omnia fluctuans Manichaeos quidem relinquendos esse decrevi. (Assim, à maneira dos acadêmicos, duvidando de de tudo, flutuando entre tudo ... resolvi abandonar os maniqueos).
} 
da academia (more academicorum), exortava-o ao discurso racional que desembocaria no dogmatismo gnóstico de Mani. Uma "elevação" (surgere) valiosa que, como veremos, abriria a possibilidade para que a gnose oferecesse suas promessas, ou laços ${ }^{83}$, de verdade e conhecimento.

\section{I,1,4 Salvação das pai xões pela Paixão.}

A despeito da importante influência que os novos acadêmicos imprimiram em Agostinho ${ }^{84}$, no livro III das Confissões, passa-se rapidamente para o limite do conteúdo do protréptico, de modo que a atenção do leitor logo se volta para a frustração do jovem: "uma só coisa me magoava no meio de tão grande ardor: não encontrar aí o nome de Cristo“. ${ }^{85}$

Eis o limite da exortação à razão que tanto impactara o jovem sedento por sabedoria. Mas o que exatamente poderia significar o "nome de Cristo" para o jovem retor, em 373, quando confessa-se tão avesso à simplicidade das Escrituras e aprisionado às realidades corporais? Brachtendorf, baseado em fragmentos do protréptico extraídos de Sobre a Trindade, pensa que o Hortênsio de Cícero poderia conter uma teologia que fosse "perfeitamente conciliável com a religião cristã" 86 , de modo que, ao jovem estudante, tanto a filosofia quanto a teologia poderiam servir-Ihe de meio para a cura da alma.

\footnotetext{
83 cf. conf III.6.10 "laquei diaboli"

${ }^{84} \mathrm{cf}$. Contra Acadêmicos

85 conf. III,4,8 et hoc solum me in tanta flagrantia refrangebat, quod nomen Christi non erat ibi,

${ }^{86}$ Brachtendorf, J. Confissões de Santo Agostinho. 2008, p. 76
} 
O estudioso ressalta que Agostinho mudaria de opinião em 387 ou ainda mais tarde, ganhando maior consciência de que, nas palavras do estudioso, "há aqui uma dicotomia" entre religião e filosofia.

Quanto a nós, evitando adentrar no tema das diversas conversões de Agostinho ${ }^{87}$., propomos avançar na interpretação do livro III somente nos dados que o autor das Confissões oferece nesse exato momento do livro ${ }^{88}$. Quando Agostinho lamenta a ausência do nome de Cristo nas penas de Cícero, na verdade, a carência que se acusa é a pura paixão que promove intimidade fraterna entre misericórdia e sofrimento, sabedoria e compaixão, ou mesmo entre razão e paixão. Em outras palavras, Agostinho buscava a semelhança entre divino e humano na própria condição passional e racional.

A narrativa que expôs o sofrimento emergido das cenas teatrais tinha desvelado a desordem passional de um prazer pela dor e sofrimento alheio. Agora, a misericórdia verdadeira, representada pelo nome de Cristo, busca uma aliança entre paixão e filosofia: anseio que não seria encontrado "naqueles livros de Cícero". Vale notar brevemente, segundo as Tusculanas, que o ilustre filósofo romano dava as diretrizes de um programa filosófico que visava apresentar uma terapia para as paixões da alma por via cognitiva. Possivelmente, o protréptico conteria semelhante formulação quanto à cura das paixões pela filosofia:

Tanto para o sofrimento (aegritudo) como para todas as outras doenças do ânimo (animi morborum), há um só remédio que é mostrar como são opiniões que

\footnotetext{
${ }^{87}$ Consultar Le Blond. Les Conversions De Saint Augustin. Paris: Aubier, 1950

${ }^{88}$ Brachtenforf busca em outros fragmentos do Hortênsio, fr. 99 I e $99 \mathrm{ll}$, a fim de justificar certa presença de uma teologia no protréptico de Cícero, pelo menos na leitura de Agostinho que teria identificado a ascensão à Deus com a vida virtuosa. Idem, p. 75
} 
contraímos por aceitá-las voluntariamente. Esta aceitação errônea das opiniões é como se fosse a raiz de todos os males e a filosofia mostra como a raiz deve ser extraída. Nos entreguemos ao cultivo da filosofia para que nos curemos a nós mesmos. ${ }^{89}$

Para Cícero, a raiz do sofrimento ou do desejo vicioso (libido) funda-se na aceitação racional das opiniões, de modo que a cura da "doença da alma" proviria de um apuramento racional por excelência. Esse programa de teor "cognitivista", por assim dizer, representa uma transformação profunda na direção afetiva do jovem retor, mas a promessa do controle do desejo pela filosofia parece não convencê-lo totalmente. Agostinho não assente a que o "cultivo da filosofia curasse a si mesmo". Não basta a supressão da paixão pela razão. É necessário intensificar a paixão na pura misericórdia; devese, portanto, resgatar as paixões humanas como tensão entre misericórdia divina e miséria humana. Agostinho parece estar atento à efetivação daquela verdadeira misericórdia. Talvez, seja esse o sentido que Agostinho teria dado à referência que fizera ao romano no começo do mesmo parágrafo: "chegou-me alguns livros de certo Cícero, cuja linguagem quase todos admiram, mas não o coração (pectus)" 90

\section{I,1,5 EM BUSCA DA CONJ UNÇÃo ENTRE AFETO E SABEDORI A}

A fim de concluirmos a contextualização da incidência maniqueia, voltemos à análise das paixões cênicas. A intimidade entre dor e misericórdia exigiu certa presença da dor na medida em que a paixão virtuosa da compaixão ou misericórdia não poderia subsistir no homem sem que houvesse alguma dor. Mas a descrição

\footnotetext{
${ }^{89}$ Cícero, Tusculanas IV, 84 apud Menezes, A., 2011, p.111

${ }^{90}$ conf. III,4,7 perveneram in librum cuiusdam Ciceronis, cuius linguam fere omnes mirantur, pectus non ita
} 
da misericórdia verdadeira não serve somente para exortar à prática ou habilitar o afeto; na verdade, a pura misericórdia manifestará ainda mais os sintomas da miséria humana que, por sua vez, revelará a impossibilidade da execução prática. Denuncia-se assim a incapacidade do homem amar misericordiosamente segundo o exemplo de Cristo.

A referência à ausência do nome de Cristo em III,4,8 parece indicar que, quando jovem, o estudante buscava nas literaturas a conjunção entre razão e paixão, ou sofrimento e virtude, se preferir. Desde a infância, portanto, Agostinho teria, pela influência de sua mãe, identificado em Cristo a compaixão e misericórdia verdadeira. A exortação à filosofia não arrefeceria o ardor pelo ideal de misericórdia que, desde tenra infância, tinha encontrado em Cristo. A verdadeira filosofia, além de curar a paixão como "doença da alma", deve exortar para uma disposição do espírito cuja paixão se intensifique na medida em que se avança no seu exercício. Cícero e as cenas teatrais são, pois, dois polos que não resolvem o dilema das paixões, mas que juntos, produzem um anseio na alma do jovem Agostinho. Eles apontam para dois aspectos da condição humana, razão e paixão, que devem ser considerados na elevação a Deus.

É importante marcar esse estado da questão para melhor compreender a adesão ao maniqueísmo, pois de alguma forma Agostinho julgou ter encontrado nas palavras maniqueias a conjunção entre discurso racional-filosófico e a intensificação das paixões no nome de Cristo. Resta, seguindo a narrativa do jovem peregrino, descrever em que medida as propostas maniqueias responderiam ao anseio intelectual e afetivo. E, em segundo momento, compreender a frustração com aquele conhecimento (gnosis) no qual permaneceu mestre e aprendiz por nove anos. 


\section{I,2 A Queda e O Delírio dos loquazes (IN hOMINes

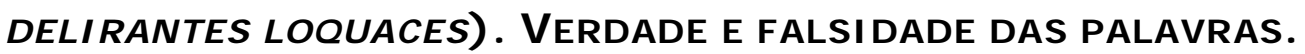

cf. Confissões III,6,9-11

Cambronne, em seu comentário ao livro III das Confissões, esquematiza a adesão maniqueia de Agostinho em três tentações que correponderiam a três pretensos saberes (gnosis): salvação das paixões (soterologia), o nome de Cristo (cristologia) e a discursividade racional (filosofia). ${ }^{91}$ Também nós, nas linhas que precederam, situamos de maneira aproximada uma divisão semelhante, com a diferença de que preferimos dar ênfase à relação passional das três áreas referidas, para que, diante desses novos amores despertados pelo desejo de conhecimento (gnosis), se examine os meandros da queda (incidi) na gnose.

\section{I,2,1 A QUEDA NAS PALAVRAS}

Antes mesmo de detalhar a tentação maniqueia, é necessário atentar à ênfase dada ao veículo da falácia, a saber, as palavras. Note-se como, já nas primeiras linhas do parágrafo 10 , Agostinho enfatiza o caráter enganador das palavras da seita: "homens carnais e loquazes", "mistura de sílabas", "pronunciavam os nomes", "falavam muito 'verdade' e 'verdade', mas não a possuíam"92

No caminho tortuoso da falácia maniqueia, a distinção entre "possuir a verdade" e dizer a "verdade" estão na base da investigação agostiniana. Não se trata, no entanto, de postular que Agostinho insira uma discussão estritamente sobre a linguagem, mas parece

\footnotetext{
${ }^{91}$ Consultar Cambronne, Patrice. Augustin et l'Église : Jalons d'un itinéraire Notes de lecture (Confessions, III-IV, 10). In: Vita Latina, $\mathrm{N}^{\circ} 115,1989$. pp. 22-36.

92 cf. conf. III, 6,10
} 
evidente que a potência da palavra como signo de verdade ou falsidade está em jogo. Com efeito, a doutrina maniqueia é meramente o veículo do engano, por isso, é necessário desvelar o engano naquilo que antecede à palavra e fazer o retorno para dentro de si, à alma que recebeu a doutrina.

A investigação sobre a relação da palavra com a verdade é, sobretudo, um exercício de introspecção do espírito. Portanto, o modo de significação é formado nas disposições do espírito diante das diversas relações passionais com as criaturas. Em uma palavra, a relação antecede o conceito, uma vez que as circunstâncias decorrentes da situação de absoluta liberdade do espírito, que se movimenta em direção ou ao ser ou ao não ser, cobram decisões e assentimentos que pesarão na interpretação dos significados das palavras.

De $111,6,10$ à $111,7,12$ das Confissões não faltarão referências a "loquacidade" maniqueia. Mas é interessante notar que, apesar do pretensioso palavrório enganador da gnose, quem introduz a relação entre verdade e falsidade das palavras não é Mani, mas Cícero. Ao romano, dedica-se poucas linhas que, no entanto, serão indícios de uma fundamental disposição do espírito: "Tive a impressão de uma obra indigna de ser comparada à majestade de Cícero". É importante marcar que, segundo o relato de Agostinho, as razões que o fizeram aproximar-se do estilo grandioso de Cícero, em detrimento da simplicidade das Escrituras, lançaram-no também no emaranhado das palavras gnósticas.

Com efeito, trata-se de comparar não tanto as palavras em seus diversos gêneros literários; mas as palavras como espelho de uma condição interior, pois o estilo simples das Escrituras não faz oposição às letras tulianas. Na verdade, as letras do estilo grandioso faz somente refletir o orgulho do jovem leitor: "Meu orgulho (tumor) 
não podia suportar aquela simplicidade de estilo. Por outro lado, a agudeza de minha inteligência (acies) não conseguia penetrar-Ihe 0 íntimo" ${ }^{93}$. Não foram as letras de Cícero que produziram a soberba, mas a soberba que causou a pecaminosa comparação. A mente perspicaz não é suficiente para penetrar na interioridade das Escrituras, pois, a verdade parece se esconder na disposição interior da alma. Tal conjunção entre verdade e simplicidade, que poderia gerar certo estranhamento ao espírito literário clássico ${ }^{94}$, exige do leitor mais do que o raciocínio (acies) ou engenho literário.

A verdade e a palavra encontram-se em um lugar bem determinado: na interioridade da alma (mens) que é capaz de penetrar o íntimo da palavra das Escrituras. Mas, quanto mais o jovem fiava-se em sua perspicácia (acies mentis) menos penetrava na profundidade interior do estilo simples das Escrituras: "o meu inchaço rechaçava o seu modo [simples] e minha perspicácia não penetrava na interioridade [das Escrituras]". ${ }^{95}$ I sto porque a falsidade e engano estão associados ao "tumor", imagem de intumescência que cega o doente para sua própria doença.

O percurso da miséria falaciosa da gnose segue num ciclo doentio de falsidade e pretensa verdade baseadas, segundo a expressão de Brachtendorf, na "falsa consciência"96 acerca de si mesmo. O pequeno estudante de retórica, ao se ver grande, rejeita a simplicidade do alimento singelo e sublime ${ }^{97}$ : "[naquele estilo

\footnotetext{
93 conf. III,5,9 sed [scripturam] visa est mihi indigna, quam Tullianae dignitati compararem Tumor enim meus refugiebat modum eius et acies mea non penetrabat interiora eius. Tradução Maria L.J. Amarante.

${ }^{94}$ Sobre a relação entre o estilo literário baixo (humilis) e a disposição do espírito humilde, consulte-se o ensaio de Auerbach, "Sermo Humilis". In: Ensaios de literatura ocidental. São Paulo: Editora 34, 2007

95 conf. III,5,9 Tumor enim meus refugiebat modum eius et acies mea non penetrabat interiora eius

${ }_{96}$ Brachtendorf, J. Confissões de Santo Agostinho. 2008, p. 71

97 cf. conf. III, 5,9
} 
simples] estava a verdade, que crescia com as crianças, mas eu desdenhava de ser pequeno, e inchado pelo meu orgulho, me via grande"98. Por essa imagem, Agostinho deixa entrever a possibilidade de alcance da verdade pela disposição humilde do espírito. De fato, Agostinho pretendia ser grande, mas ainda era como criança. O jovem retor recusava a comida simples que serviria adequadamente ao desenvolvimento da criança em crescimento. Mas a criança, achando-se grande, não se alimentava das palavras simples e nutritivas das Escrituras; ao contrário, preferia as letras grandiosas. Primeiramente, a "falsa consciência" alimentou-se da grandiosidade do estilo de Cícero em detrimento da interioridade das Escrituras; depois, lançou-se na doutrina racionalista de Mani.

A adesão à gnose é descrita como um momento de auto alienação, cuja ilusão consiste em tomar o falso por verdadeiro. Essa inversão de ordem está diretamente relacionada com o modo como o homem opera as relações entre as duas substâncias que o compõe: corpo e alma. A metáfora da nutrição representa o momento em que Agostinho compara as palavras dos maniqueus como alimentos 'vazios' (inane) que serviram ao corpo, mas não ao espírito:

Caí assim nas mãos de homens orgulhosamente extravagantes, demasiado carnais e loquazes. Havia na sua boca laços do demônio e um visco preparado com a mistura de sílabas do vosso nome, do Nosso Senhor Jesus Cristo e do Paráclito consolador, o Espírito Santo. Jamais esses nomes se lhes retiravam dos lábios, mas eram apenas sons e estrépito da língua. O seu coração estava vazio de sinceridade. Diziam: "Verdade e mais verdade!" ${ }^{99}$.

\footnotetext{
98 conf. III,5,9 Verum autem illa erat, quae cresceret cum parvulis, sed ego dedignabar esse parvulus et turgidus fastu mihi grandis videbar.

99 conf. III,6,10 Itaque incidi in homines superbe delirantes, carnales nimis et loquaces, in quorum ore laquei diaboli et viscum confectum commixtione syllabarum nominis tui et Domini lesu Christi et Paracleti consolatoris nostri Spiritus Sancti. Haec nomina non recedebant de ore eorum, sed tenus sono et strepitu
} 
O caminho de peregrinação nessa fase maniqueia fora marcado pelo "visco preparado com a mistura de sílabas" (viscum confectum commixtione syllabarum) ${ }^{100}$ : mesmos signos, mas com significados diferentes. As meras sílabas formavam as palavras, que, por sua vez, formavam as falaciosas ficções maniqueia. Mas ao expor este percurso de engano que percorre desde a menor partícula da materialidade linguística, a sílaba, até a crença na falácia da ficção maniqueia, Agostinho não pretende indicar o esvaziamento da linguagem; antes, pretende denunciar o "coração vazio de verdade" (cor inane veri). Com efeito, o erro não é da ficção em si, mas do modo como o leitor as significa ${ }^{101}$.

Eis o cenário linguístico da queda maniqueia que, longe de apresentar qualquer formulação teórica da linguagem, elaborou imbricações profundas entre ontologia e ética. A superação das palavras é de partida uma tarefa que não se atém na passagem do corpo ao espírito, mas busca no interior de si os modos de relação com os quais o homem, "situado no meios das coisas"102, necessariamente deve "aprender por experiência" ${ }^{103}$.

\section{I,2,2 Verdade e PALAVRAS SUPERADAS (TRANSGREDI)}

"E diziam: "Verdade e verdade!" E falavam muito dela mas [a verdade] não estava neles! Ao contrário, falavam falsamente, não só de ti, que verdadeiramente és a Verdade, mas também acerca dos elementos deste mundo, tuas criaturas. Eu deveria ter ultrapassado essas [palavras] que falavam, ainda que fossem filósofos que ensinassem coisas verdadeiras. Isso por

linguae; ceterum cor inane veri. Et dicebant: "Veritas et veritas. Tradução de J. Oliveira Santos e A. Ambrósio de Pina. Com alterações nossas

${ }^{100}$ conf. III, 6, 10

101 Consultar Oort, Van. Augustine and manichaeism: new discoveries, new perspectives. In: Verbum et Ecclesia, 27(2). 2006. Oort defende que Agostinho teria sido atraído pela piedade da doutrina maniqueia, p. 714.

102 Consultar nossa introdução, análise de Gn. c. man. II, 9,12.

103 idem 
amor de ti, Pai sumamente bom e Formosura de todas as formosuras," 104

Agostinho reconhece que o encontro com as palavras verdadeiras dos filósofos representava um avanço em comparação às palavras vazias dos maniqueus. No entanto, avisava que mesmo as palavras da boa filosofia deveriam ser superadas (transgredi), pois as coisas verdadeiras ainda não são a verdade. Não se pretende afirmar que as palavras devem ser recusadas como degraus de acesso à verdade; antes devem ser superadas (transgredi) a fim de ir além delas, conservando-as. Essa relação ambivalente com a palavra dos filósofos será apresentada nas Confissões VII, mas aqui Agostinho já deixa anunciado que a passagem da palavra verdadeira para a verdade da palavra é exercício de superação. Pode-se dizer, assim, que o pano de fundo da queda maniqueia encontra-se na relação entre palavra e a verdade; ou melhor, na relação entre a disposição do espírito e significação. Uma relação que se sabe, desde o diálogo Sobre o Mestre, fracassada no modo estrito dos signos exteriores.

Posto o problema de maneira um tanto geral, passemos a três casos particulares, que, segundo Cambronne, representam os três falsos saberes da tentação maniqueia ${ }^{105}$. Vejamos como Agostinho articula palavra e significação no contexto da falácia maniqueia.

\section{I,2,3 A falácia de misturas de sí labas (CRistologi A)}

\footnotetext{
104 conf. III,6,10 Et dicebant: "Veritas et veritas", et multum eam dicebant mihi, et nusquam erat in eis, sed falsa loquebantur non de te tantum, qui vere Veritas es, sed etiam de istis elementis huius mundi, creatura tua, de quibus etiam vera dicentes philosophos transgredi debui prae amore tuo, mi pater summe bone, pulchritudo pulchrorum omnium.

105 Conforme mencionado anteriormente: cristologia, moral e discurso racionalfilosófico.
} 
O primeiro engano alude ao nome de Cristo (cristologia). O projeto de saber gnóstico é pretensioso e não economiza nas palavras: “E Diziam [maniqueus]: 'verdades e verdades', e diziam para mim muitas coisas" ${ }^{106}$. E o que faltou em Cícero é encontrado em abundância na gnose:

(...) um visco preparado com a mistura de sílabas do teu nome, do de nosso Senhor Jesus Cristo e do Paráclito consolador, o Espírito Santo. Jamais esses nomes se Ihes retiravam dos lábios ${ }^{107}$

Essa fórmula trinitária quando colocada na boca do maniqueu, enlaçava o jovem estudante de retórica que, atraído pela mistura de nomes divinos familiares, desfalecia de um amor insuficiente. As palavras arrogavam-se "verdadeiras", mas que ao fim eram elas que o impediam de encontrar a verdade.

O maniqueísmo usava das mesmas palavras, incluso o nome de Cristo carente ao Hortênsio. Eram como falsos alimentos que forneciam algum deleite por amor, mas ainda não era o amor. (Nondum amabam et amare amabam. Confissões III,1,1)

Cambronne descreve a tentação de ordem cristológica:

Em primeiro lugar, é necessário lembrar o lugar central que a figura de Cristo ocupa no maniqueísmo, e que desde o início, no Evangelho de Mani, o primeiro dos tratados do Heptateuco maniqueu (que corresponde ao agrupamento original da Escrituras maniqueia), Mani é chamado de 'apóstolo de Jesus Cristo', 'Paracleto anunciado por Cristo', os Mistérios (quarto tratado do Heptateuco se apoiavam sobre o Evangelho de Thomas,

\footnotetext{
${ }^{106} \mathrm{cf}$. conf. III,6,10 Et dicebant: "Veritas et veritas", et multum eam dicebant mihi 107 conf. III,6,10 et viscum confectum commixtione syllabarum nominis tui et Domini Iesu Christi et Paracleti consolatoris nostri Spiritus Sancti. Haec nomina non recedebant de ore eorum. Tradução de J. Oliveira Santos e A. Ambrósio de Pina. Com alterações.
} 
e são consagrados, em parte, ao 'testemunho de Jesus sobre sua alma'. 108

Vê-se que o nome de Cristo é central, no entanto o espanto do Agostinho maduro não é bem a falsidade da linguagem maniqueia, mas o modo pelo qual o jovem acreditara nela. O que está em julgamento não é bem a doutrina gnóstica, mas a razão, ou a capacidade de interpretar a palavra e discernir o verdadeiro do falso.

\begin{abstract}
Eram-me apresentadas imagens fantasiosas e brilhantes; teria sido melhor amar o próprio sol, verdadeiro ao menos para os olhos [carnais], em lugar daquelas falsidades destinadas a enganar a alma através dos olhos. Alimentava-me, no entanto, de tais manjares, porque pensava que eras tu, mas na realidade não o fazia com grande avidez, porque não tinham o teu autêntico sabor; e longe de me nutrirem, me debilitavam cada vez mais. A comida em sonho é muito semelhante à comida real, mas os que sonham não se alimentam, porque dormem. No entanto, aqueles alimentos de modo algum eram semelhantes a ti: agora o sei, porque a mim o revelaste. ${ }^{109}$
\end{abstract}

\footnotetext{
108 Tout d'abord, il nous faut bien rappeler la place centrale qu'occupe la figure du Christ dans le Manichéisme, et cela dès ses débuts : dans l'Évangile de Mani, le premier des traités de l'Heptateuque manichéen (qui correspond au groupement originel des Écritures Manichéennes). Mani est appelé "Apôtre de Jésus-Christ", "Paraclet annoncé par le Christ" ; les Mystères (quatrième traité de I'Heptateuque), s'appuient sur l' Evangile de Thomas, et sont consacrés, en partie, au 'témonage' de Jésus sur son âme (...).Cambronne, Patrice. Augustin et l'Église : Jalons d'un itinéraire Notes de lecture (Confessions, III-IV, 10). In: Vita Latina, $\mathrm{N}^{\circ} 115,1989$. pp. 22-36

109 conf. III,6,10. Et apponebantur adhuc mihi in illis ferculis phantasmata splendida, quibus iam melius erat amare istum solem saltem istis oculis verum quam illa falsa animo decepto per oculos. Et tamen, quia te putabam, manducabam, non avide quidem, quia nec sapiebas in ore meo sicuti es (neque enim tu eras illa figmenta inania) nec nutriebar eis, sed exhauriebar magis. Cibus in somnis simillimus est cibis vigilantium, quo tamen dormientes non aluntur: dormiunt enim. At illa nec similia erant ullo modo tibi, sicut nunc mihi locuta es, quia illa erant corporalia phantasmata, falsa corpora, quibus certiora sunt vera corpora ista, quae videmus visu carneo, sive caelestia sive terrestria; cum pecudibus et volatilibus videmus haec, et certiora sunt, quam cum imaginamur ea. Et rursus certius imaginamur ea quam ex eis suspicamur alia grandiora et infinita, quae omnino nulla sunt. Qualibus ego tunc pascebar inanibus et non pascebar.. Tradução de Maria L. Amarante. Alteração e grifo nossos.
} 
Assim como um homem que sonha não sabe que sonha e vive no torpor das sensações vazias, assim é a doença que aflige o jovem retor. Tudo se passa na mente, mas sua capacidade mais excelente, que o difere dos animais, parece incapaz de escapar à falsa consciência. A falácia maniqueia expõe o limite da razão, da perspicácia mental (acies mentis), e permite que Agostinho descreva toda a dificuldade humana de realizar a ultrapassagem da palavra ao seu significado interior. O engano, portanto, parece estar justamente no que seria a solução, a capacidade judicativa.

Cambronne aponta, nesse aspecto da filosofia agostiniana, certa "inconsciência" na queda cristológica: "Agostinho (...) não tinha absolutamente consciência de trair a fé cristã: o maniqueísmo lhes oferecia, entre outras coisas, uma leitura possível da mensagem evangélica".

De fato, Agostinho já tinha anunciado ${ }^{110}$ que nunca renunciara por completo o cristianismo da igreja católica. No entanto, não fica claro que Agostinho entenda sua queda no maniqueísmo como um assentimento causado por ignorância. Poderá ser temerário reputar a fase maniqueia a uma "inconsciência". O alcance dessa associação, ainda que não seja a intenção do estudioso, pode intelectualizar o pecado, o que definitivamente não é o caso de Agostinho, pelo menos na narrativa que o escritor faz de si quando jovem.

Que as palavras enganadoras da gnose diziam mentiras em vez da verdade, e que aquele que acredita na mentira não tem consciência à época da crença, é evidente e ninguém contesta. Agostinho, no entanto, não se preocupa em demonstrar o quão semelhante o gnosticismo cristão de Mani é do cristianismo católico.

${ }^{110}$ cf. conf. III,4,7 e duab. an. I,1 
Concentra-se mais na exposição de suas motivações profundas de crer. Se não há um ato consciente (racional) a confessar, há uma disposição do espírito para este ou aquele afeto. Trata-se então de explorar um estado de alienação da alma a si mesma por um ponto cego à razão, de onde podemos agora concordar, já com os devidos esclarecimentos, que Agostinho "não teria tido consciência" da diferença entre cristianismo gnóstico e o católico; ou melhor dito, o jovem retor teria tido uma "falsa consciência"111 de si. De fato, o que é confessado é mais a disposição de auto alienação que por fim nubla a visão interior e faz com que o juízo transgrida a ordem da primazia dos inteligíveis que as evidências racionais de um cálculo mal feito.

Eis o procedimento, na gnose, de atribuição de valor ontológico aos significados das palavras:

Eram certamente imagem fantasiosa (phantasmata), falsos corpos. Mais verdadeiros do que eles são os corpos celestes ou terrestres que vemos com os olhos da carne. E os vemos como os vêem os animais e as aves, e têm mais segurança (certius) do que as imagens que deles formamos. Por sua vez, tais imagens são ainda mais seguras do que as suposições que nos sugerem (suspicamur), maiores e infinitas; contudo não existem de modo algum. São como aquelas fantasias com as quais eu então me alimentava e não me saciavam. ${ }^{112}$

Há uma gradação descendente aqui. Os corpos celestes são menos verdadeiros que os animais que os percebem pelos sentidos. Estes corpos são seres criados e compõem a positividade da criação. As imagens desses corpos são mais reais e seguras (certius)do que

\footnotetext{
${ }^{111} \mathrm{cf}$. Brachtendorf. Ver nota anterior

112 conf. III,6,10. illa erant corporalia phantasmata, falsa corpora, quibus certiora sunt vera corpora ista, quae videmus visu carneo, sive caelestia sive terrestria; cum pecudibus et volatilibus videmus haec, et certiora sunt, quam cum imaginamur ea. Et rursus certius imaginamur ea quam ex eis suspicamur alia grandiora et infinita, quae omnino nulla sunt. Qualibus ego tunc pascebar inanibus et non pascebar.. Tradução de Maria L. Amarante. Alteração e grifo nossos.
} 
as imagens fantasiosas produzidas pela composição mental de imagens corporais. Essas suposições que se formam a partir da imaginação (phantamasta) podem sugerir espaços infinitos e grandiosos, mas serão enganadoras, se cridas, porque na realidade nada são (ominino nulla sunt). São meras suposições a partir de imagens de corpos reais; no entanto, elas mesmas não passam de composição mental sem representatividade corporal ou inteligível.

O que Agostinho parece defender aqui é que as imagens (phantasias) são mais verdadeiras dos que as imaginações (phantasmatas), embora as primeiras tenham origem sensível; e as segundas mentais. Mais ainda, a pequena imagem de um corpo ínfimo qualquer é superior ao infinito imaginado.

Esse deslocamento do infinito corporal para o infinito imaginado já é um passo importante de ser marcado, pois o maniqueu, relata o hiponense, pensa Deus como uma realidade infusa no mundo ou difusa no espaço infinito ${ }^{113}$. Agostinho, ao contrário, critica a ideia da realidade do infinito corporal em grandezas cada vez maiores, ${ }^{114}$ uma vez que o infinito corporal passa a ser apenas um produto da atividade mental que coleta imagens corporais verdadeiras e as compõem em imaginações que não são substanciais.

Mas no momento em que a alma recusa o infinito corporal, ela descobre nela mesma a potência de um infinito interior ${ }^{115}$, ainda que imaginado. Aqui, inverte-se o pensamento maniqueu. Ao invés da alma estar contida no espaço infinito, ela mesma contém em si a

\footnotetext{
113 conf. VII , 1, 1

114 Agostinho concede que o infinito corporal por divisão; mas a realidade infinita por multiplicação (maiores) é possível apenas a partir do inteligível. cf. Carta a Nebrídius (ep. III) ; Consultar também Hadot, P. La notio d'infini chez Saint Augustin. Philosophie 26, 1990

115 cf. Hadot, idem, p. 64
} 
possibilidade de imaginar o infinito ${ }^{116}$, visto que nela reside uma "potência inefável"117 de multiplicação de grandezas.

É nesse ponto que a falácia maniqueia cria o seu simulacro, isto é, no momento da suposição, quando pensa que a mente seja capaz de imaginar realidade sobre corpos mais reais do que verdadeiras imagens de corpos (phantasia), e ao procederem assim nada fazem senão imaginar "falsos corpos".

Ademais, Agostinho parece apontar para a disposição do espírito por detrás da suposição. A perspicácia mental do maniqueu faz dele um pretensioso, arrogando ser capaz de nomear o que está além da possibilidade de qualquer representação ou objetivação. Por outro lado, a passagem para o “infinito interior” também guardará tentações. Para não cair na mesma arrogância do maniqueu é necessário que a alma reconheça que Deus antecede a alma intelectiva:

Quão longe estais, portanto, daquelas minhas quimeras, ficções de corpos que de nenhum modo existem! ... Mas também não sois a alma que é a vida

\footnotetext{
${ }^{116}$ Contra epistolam fundamenti 17.20 Nunc vero cum perexiguam terrae partem occupet corpus, immensarum regionum et coeli ac terrae imagines animus volvit, quibus catervatim discedentibus ac succedentibus non fit angustus: atque hinc se ostendit non diffusum esse per locos, quia maximorum locorum imaginibus non quasi capitur, sed potius eas capit; non sinu aliquo, sed vi potentiaque ineffabili, qua licet eis et addere quodlibet et detrahere, et in angustum eas contrahere, et per immensa expandere, et ordinare ut velit, et perturbare, et multiplicare, et ad paucitatem singularitatemve redigere. (But while the body occupies a small material space, the mind revolves images of vast extent, of heaven and earth, with no want of room, though they come and go in crowds; so that clearly, the mind is not diffused through space: for instead of being contained in images of the largest spaces, it rather contains them; not, however, in any material receptacle, but by a mysterious faculty or power, by which it can increase or diminish them, can contract them within narrow limits, or expand them indefinitely, can arrange or disarrange them at pleasure, can multiply them or reduce them to a few or to one)Tradução: Nicene e Post-Nicene Father, vol. VII

117 idem, idem. sed vi potentiaque ineffabili
} 
dos corpos - esta vida dos corpos melhor e mais real do que os corpos ${ }^{118}$

Ainda que alma possa conjecturar imagens fictícias do infinito, não pode ela conter o infinito Deus. Isso porque Deus está sempre além de qualquer ato de pensamento ou, mais especificamente, ele está além de qualquer conjectura mental ao infinito. Em suma, Deus não está contido no mundo de multiplicidade. Sua unidade infinita não pode ser representada pela alma que pensa por composição de partes, reduzindo-as ou acrescentando-as. Há uma distância que separa criatura e criador; alteridade que a alma humana deve humildemente respeitar: "sois a vida das almas, a Vida das vidas, que vive em razão de si mesma, e que não muda, ó Vida da minha alma!"119

\section{I,2,4 Presença e distância de Deus (Soteri ologi A)}

Primeiramente, tomemos a análise de Puech:

Como em todas as gnoses, o conhecimento de si e conhecimento de Deus contém nele a certeza da Salvação. Conhecer a si é, em efeito, se reconhecer, retornar e recuperar seu verdadeiro 'eu', ainda que obnubilado pela ignorância e inconsciência, onde o homem se encontra mergulhado na mistura com os corpos e a Matéria: a gnosis é epignosis; o conhecimento, reconhecimento, recordação de si. ${ }^{120}$

\footnotetext{
118 conf. III,6,10 Quanto ergo longe es a phantasmatis illis meis, phantasmatis corporum, quae omnino non sunt! Quibus certiores sunt phantasiae corporum eorum, quae sunt, et eis certiora corpora, quae tamen non es. Tradução de J. Oliveira Santos e A. Ambrósio de Pina

119 conf. III,6,10 sed tu vita es animarum, vita vitarum, vivens te ipsa et non mutaris, vita animae meae. Tradução de J. Oliveira Santos e A. Ambrósio de Pina

120 Comme dans toutes les gnoses, égalemente, cette connaissance de soi et de Dieu contient en elle la certitude du Salut. Se connaître, c'est en effet, se reconnaître, retrouver et récupérer son vrai 'moi', auparavant obnubilé para l'ignorance et l'inconscience où le mélange avec le corps et la Matière plonge
} 
Se aceitarmos a avaliação de Puech, é preciso reconhecer, concordando com Cambronne ${ }^{121}$, que há um campo de temas compartilhado entre Agostinho e a gnose maniqueia. E, desde já, é necessário precisar o significado de distância e presença entre homem e Deus nas duas doutrinas.

A gnose tem dois eixos muito bem marcados na caracterização geral da religião gnóstica. Primeiro, sobre a semelhança entre Deus e alma: “Há consubstancialidade entre Deus e as almas: as almas somente são alguns fragmentos da substância divina"122. Então, pode-se dizer que, no limite, o próprio Deus é a luz de nossa alma aprisionada em nosso corpo. O maniqueísmo tanto quanto o cristianismo de Agostinho é uma doutrina da salvação. O homem está aqui, longe de Deus, e a salvação está lá, com Deus. Na gnose, o conhecimento de Deus se funde no conhecimento do homem, pois, o homem é o próprio deus esquecido na mistura de espírito e matéria. Consequentemente, a salvação consiste no conhecimento (gnosis) de si como recordação, ou seja, uma tomada de consciência de sua própria divindade (epignosis).

Segundo, a dessemelhança com o divino é um tipo de contaminação do "verdadeiro homem", um estado de mergulho da alma pura num mundo poluído de corpos e matéria ${ }^{123}$. Nesse sentido,

I'homme: la gnosis est épignosis ; la 'connaissance', 'reconnaissance', ressouvenir de soi. Or, dans le manichéisme, se reconnaître et se retrouver dans son authenticité ontologique équivaut à se saisir comme une parcelle de lumiére originaire du monde transcendant, e qui, en outre, ne cesse pas, malgré son abjection actuelle, de rester unie à ce monde supérieure par un lien éternel et immanent. Le point est capital. II y a consubstantialité entre Dieu et les âmes : les âmes ne sont que des fragments de la substance divine. Puech, C.H-. Histoire des Religions II. pp. 554-555

${ }^{121}$ Supra cit.

122 Puech, C.H-. Histoire des Religions II. pp. 555

123 le dualisme est d'abord transcendental, c'est-à-dire qu'il est la croyance à um être au dela de nous et de notre tout Petrement, S. Le dualisme chez platon, les gnostiques et les manicheens -- Paris : Puf, 1947 p. 309-310 
o mal é o próprio mundo; ou melhor, é "um sentimento experimentado do mal do mundo e da condição humana"124.

Destarte, a caracterização da doutrina da salvação maniqueia permitiu-nos, embora bastante resumida, esboçar dois conceitos que Agostinho deverá afastar-se. Por um lado, a noção gnóstica de semelhança como consubstancialidade entre alma e Deus; e, por outro, a dessemelhança como experiência substancializada do mal sentido no mundo.

\section{SEMELHANÇA: I NTERI ORI DADE E ANTERI ORI DADE DO AMOR.}

Ainda não amava e amava amar (Nondum amabam et amare amabam ). Confissões III,1,1

Mas tu eras mais interior do que do há de mais interior em mim e mais superior do que o meu superior (ut autem eras interior intimo meo et superior summo meo). Confissões III, 6,11

Até aqui, vimos a exortação ao uso das palavras no quadro da falácia maniqueia. O dilema da falsidade das palavras que diziam "verdade e verdade" funda-se justamente na insuficiência dessa quase boa notícia (evangelho) de salvação, veiculada pela boca de “homens delirantemente loquazes".

Insuficiência porque Agostinho descobre em si mesmo, na alma, tanto a presença quanto a ausência de um desejo. Retomemos a famosa frase presente no prólogo do livro III: “ainda não amava e

124 cf Puech : "Je crois, contrairement à S Pétrement (p.310), que le sentiment ainsi éprouvé du carctere mauvais du monde et de la condition humaine est ici essentiel et qu'il précède - psychologiquement ou dialectiquement - celui de la transcendance tenu par cet auteur pour l'élément primaire ou primordial de la conscience gnostique ou dualiste." - eu creio que, contrariamente a S. Pétrement, que o sentimento assim experimentado do mal do mundo e da condição humana é aqui essencial e que ele precede - psicologicamente ou dialeticamente - aquela da transcendência, considerada por Pétrement como o elemento primário ou primordial da consciência gnóstica ou dualista. Puech, opera cit. p. 152 
amava amar" (Nondum amabam et amare amabam ). Ora, a frase remete, talvez não por acaso, à estratégia do projeto confessional apresentado logo nas primeiras linhas das Confissões. Parece, assim, oportuno, relacionar a falácia das palavras maniqueias com o quadro mais geral das Confissões:

Tu o incitas para que sinta prazer em louvar-te; fizestenos para ti, e inquieto está o nosso coração enquanto não repousa em ti. Dá-me, Senhor, saber e compreender qual seja o primeiro: invocar-te ou louvar-te; conhecer-te ou invocar-te. Mas quem te invocará sem te conhecer? ${ }^{\mathbf{1 2 5}}$.

Sem a pretensão de dizer tudo sobre as ricas frases do prólogo, sabidamente matizadas em detalhe e cuidado linguístico que impressionam, retomemos apenas a circularidade conceitual entre 0 par invocação e louvação, e invocação e conhecimento. Na primeira frase, Agostinho expressava que a louvação é condição de identidade e repouso do homem, mas o louvar implica de alguma maneira a invocação, visto que a louvação pressupõe alteridade. No entanto, a comunicação com o outro, operada pela invocação, levanta a questão se aquele que é invocado é conhecido pelo invocante. A questão é grave, pois pode acontecer, no pior dos casos, que o louvor seja dirigido ao invocado que não é o verdadeiro Deus. Mais grave ainda se não houver alteridade, pois a invocação do outro se identificaria com a invocação de si, supondo que homem e Deus são da mesma substância.

Agostinho, então, muda o par para invocação e conhecimento: o que deve acontecer primeiro? Se primeiro a invocação, é necessário conhecer para invocar; se primeiro o

\footnotetext{
125 conf. I,1,1 Tu excitas, ut laudare te delectet, quia fecisti nos ad te et inquietum est cor nostrum, donec requiescat in te. Da mihi, Domine, scire et intellegere, utrum sit prius invocare te an laudare te et scire te prius sit an invocare te. Tradução: Maria L. J. Amarante. Ed Paulus, 2002.
} 
conhecimento, que tipo de conhecimento de Deus é esse que se dá sem invocação? Ora invocar a Deus é dizer uma palavra, por exemplo "Senhor", mas em que sentido realmente possuímos conhecimento de Deus para além do seu signo vocal? E se desde a primeira linha, Deus é a "sabedoria que não tem limite (non est numerus)", isto é, Deus é o que não pode ser contado, o Uno, se quiser, pelo qual tudo é compreendido e numerado, no entanto, ele mesmo não é numerado ou compreendido por ninguém, como, ao mesmo tempo, "Deus é grande e muito louvável" (Magnus es, Domine, et laudabilis valde)?

Estabelece-se uma tensão entre impossibilidade e possibilidade que não terá solução no caráter restrito das potências humanas. É necessário incluir humildemente a petição na invocação. Eis a prece: "Dá-me, Senhor, saber e compreender", que permite retornar à circularidade do par: o conhecimento de Deus é um limite de partida e de chegada, que gera uma circularidade entre invocar (palavra) e conhecimento, prece e dádiva. Ora, a nosso ver, a fim de habilitar alguma invocação do verdadeiro Deus, é necessário que Deus responda o pedido. Petição e resposta que sugerem vontade e movimento da alma em direção ao objeto do desejo, isto é, comunicação entre alteridades singulares.

Ora, a petição, contudo, não resolve a circularidade do amor ao Amor. A petição apenas reconhece humildemente uma ambivalência da presença de Deus no homem, que agora podemos dizer com mais clareza tratar-se de imanência e transcendência.

Imanência e transcendência são polos de uma tensão paradoxal, dirá E. Bermon ${ }^{126}$ ao analisar o famoso enunciado das Confissões III, 6,11: “Mas tu eras mais interior do que do há de mais

126 Bermon. Le Cogito..., 2001. “La distinction entre la présence et l'invention (invenire cf. conf. X,25,26) s'aplique donc à Dieu de façon paradoxale », p. 282 
interior em mim (interior intimo meo) e mais superior do que o meu superior". ${ }^{127}$ Passemos a examinar essa tensão na sequência do texto.

Ao expor a diferença entre a verdade no interior das ficções bíblicas e a crença na falsidade das fábulas maniqueias, o escritor das Confissões pode reconhecer tanto a distância quanto presença do divino na alma, outrora, nublada e inconfessa. Podemos, agora, retomar esta breve e famosa definição de Deus, que remete a dois modos de percepção do divino pela alma ${ }^{128}: 1$ ) a presença de Deus na alma, imanência; e (2) que Deus seja além do homem, o outro transcendente dentro da alma humana. Assim, Deus é, ao mesmo tempo, a própria fundamentação da minha interioridade (semelhança e identidade) e o "interioríssimo" para além de mim (dessemelhança e diferença). Madec, reforça essa ideia ao atentar para a junção do comparativo ao superlativo como segundo termo de comparação no ablativo. Parte da análise semântica da frase e identifica a adjetivação do substantivo de comparação "interior"; exigindo o segundo termo de comparação no caso ablativo "intimo meo", mas "intimo" já é superlativo, o que por sua vez aponta para o caráter de superação e transcendência do espírito humano para Deus ${ }^{129}$.

Essa tensão constitutiva do homem em relação à Deus antecede a própria relação amorosa com todas as outras coisas, (Nondum amabam et amare amabam ). É a partir desse amor pelo Amor sempre lá, dentro da alma, que as coisas do tempo são

\footnotetext{
127 conf. III,6,11 ut autem eras interior intimo meo et superior summo meo

${ }^{128}$ Cf. Solignac In: BA 13, p. 383, n.2. Solignac BA 13, p. 383, n.2. Como Madec, Solignac aponta ao a duplo aspecto : imanência e transcendência de Deus no alma do homem. Assim, Deus é ao mesmo tempo o mais íntimo (identidade) o todo outro, mais superior (dessemelhança, alteridade) do que o homem, quando comparado o pecado humano e a santidade divina.

${ }^{129}$ cf. Madec, Goulvean. Conversion, Intériorité, Intentionnalité. in :. Petites Études Augustiniennes
} 
recuperadas pelo espírito para serem amadas como exortação (admonitio) a amar o Amor.

EXTERI ORI DADE

DI SSI MI LI TUDI NI S)
$\mathbf{E}$

DESSEMELHANÇA
( REGIO
(CONFISSÕES III ,6,11)
Em Agostinho, "região de dessemelhança" (regio dissimilitudinis ${ }^{130}$ ) é de outra ordem:

\begin{abstract}
Atingistes a minha vista enferma, brilhando com veemência sobre mim. Tremi com amor e temor. Pareceu-me estar longe de Vós numa região distante (regio dissimilitudinis), como se ouvisse a vossa voz lá do alto: "Sou o pão dos fortes; cresce e de mim te alimentarás. Não me transformarás em ti como ao alimento da tua carne, mas te transformarás em mim" $^{131}$
\end{abstract}

Visto que alma não é uma partícula de luz ou fragmento do divino, a voz de Deus deve ressoar "não do cume do monte do corpo, mas do alto de sua substância", no mais íntimo da alma e para além da alma.

Em sentido agostiniano, "alimentar-se de Deus" é um ato de reconhecimento de um estado baixo para onde a voz do alto se dirige, porque é justamente na consciência da distância (dissimilitudinis) em que a voz interior soará aos ouvidos interiores, ou melhor, em que o ouvido interior perceberá a perene voz divina afirmando a semelhança. Em Agostinho, a salvação como

\footnotetext{
130 Consultar A. Solignac. Presence à soi-même et presence à Dieu d'apres Porphyre, In: B.A 13, nota 23, p. 679; idem, p.689, nota 26, regio dissimilitudinis. 131 conf. VII,10,16 Et reverberasti infirmitatem aspectus mei radians in me vehementer, et contremui amore et horrore; et inveni longe me esse a te in regione dissimilitudinis (Evang. Lucas 15,13), tamquam audirem vocem tuam de excelso: "Cibus sum grandium: cresce et manducabis me. Nec tu me in te mutabis sicut cibum carnis tuae, sed tu mutaberis in me". Tradução de J. Oliveira Santos e A. Ambrósio de Pina, 1980.
} 
conhecimento de si não é definitivamente uma epignosis gnóstica que "transforma Deus em homem". Conhecer a si é reconhecer-se em "região de dessemelhança", isto é, Deus é a pura interioridade na alma, mas sem consubstancialidade; e a "experiência do mal sentido no mundo" não é outra coisa senão a alma pecadora.

Se Puech e H. Jonas estão corretos em suas descrições da gnose maniqueia, Agostinho é preciso no ponto essencial de afastamento. Se para o maniqueu, o projeto de salvação a partir da exterioridade tinha, aos olhos do escritor das Confissões, a pretensão de transformar Deus em homem; para Agostinho, a voz interior comandava o inverso: mudar o homem à semelhança de Deus ( $\mathrm{Nec}$ tu me in te mutabis sicut cibum carnis tuae, sed tu mutaberis in me). Em outras palavras, a interioridade deve preceder a exterioridade a fim de que, e somente assim, as coisas de fora sejam devidamente contempladas pela "potência raciocinante" (juízo) ${ }^{132}$.

A salvação a partir da interioridade reconhece que a dessemelhança é o contraponto de sua semelhança, pois não saberia ser diferente, se antes já não tivesse sido semelhante. A dessemelhança é a distância entre o amor em ato e o desejo de amar: "já gostava de amar, mas ainda não amava" ${ }^{133}$.

132 conf. VII,17,23 "e dessa forma, por degraus, dos corpos até a alma, que sente pelos corpos, e da alma até a sua força interior, a qual os sentidos anunciam as coisas exteriores, que é o limite das potências dos animais, e dali até a potência raciocinante, à qual pertence o juízo. O juízo, por sua vez, ajuíza (sumere) segundo os sentidos dos corpos, mas mesmo ele se dá conta que é mutável e por isso se eleva até o seu intelecto. .... Disso provinha o seu conhecimento a respeito do próprio Imutável, pois, caso não o conhecesse de alguma maneira (aliquo modo), não o anteporia com toda a segurança ao variável, e assim ela alcançou aquilo que é o ser, num relance (ictu) de uma visão trepidante". Agostinho recorre às Escrituras para apoiar o projeto vincadamente neoplatônico: "Pois desde a criação do mundo os atributos invisíveis de Deus, seu eterno poder e sua natureza divina, têm sido vistos claramente, sendo compreendidos por meio das coisas criadas, de forma que tais homens são indesculpáveis" Epístola aos Romanos 1,20. Tradução de J. Oliveira Santos e A. Ambrósio de Pina, 1980.

133 cf. conf. III, 1,1 
O desejo inerente à alma, naturalmente semelhantedessemelhante, dá estatuto de plena liberdade ao homem que, se quiser, peca, pois o movimento pecaminoso da alma aos corpos é o desejo de fruir (amar) no que é mutável. Mas amar os corpos é a maneira agostiniana de dizer que o espírito se submeteu ao corpo; quando deveria ter usado o corpo para amar a Deus.

Entende-se porque o caminho do peregrino à casa do pai (patria) deve passar pela reconstituição de sua história pessoal (perigrinatio), pois nas memórias que guardam a errâncias da dessemelhança, também guardam o desejo do amor (semelhança). Beierwaltes pôde, assim, afirmar algo semelhante quanto ao conceito agostiniano de felicidade em relação a regio dissimilitudinis:

A definição de Agostinho sobre a vida feliz deve ser vista, antes de tudo, em referência ao seu oposto, a vida infeliz, miserável com ela mesma, "neste mundo" (...) Em resumo, a regio dissimilitudinis ${ }^{134}$, na medida em que, e tão logo seja reconhecida como tal, de fato provoca sua própria transcendência para a similitudo ou unidade, que é também regio beatitudinis ${ }^{135}$

Pode-se afirmar que confessar os degraus da descensão torna-se também um degrau essencial da ascensão:

Ai de mim, ai de mim! Que por degraus (gradibus) desci às profundezas do inferno. Sofrimento e febre pela falta da verdade enquanto te buscava. (A ti, Deus meu, confesso: tu foste misericordioso quando eu ainda não confessava). Não buscava com o intelecto da mente, com a qual me quiseste superior aos animais, mas com o sentido da carne. ${ }^{136}$

\footnotetext{
134 cf. conf. VII,10,16

135 Beierwaltes, W. Regio Beatitudinis. Augustine's Concept of Happiness, 1980, p. 40

136 conf. III, 6,11 Vae, vae! Quibus gradibus deductus in profunda inferi, quippe laborans et aestuans inopia veri, cum te, Deus meus (tibi enim confiteor, qui me miseratus es et nondum confitentem) cum te non secundum intellectum mentis,
} 
De novo, não há obviedades. A busca por Deus segundo o "intelecto da mente", o nous de Plotino e parte superior da alma, é surpreendentemente associada ao ato confessional ${ }^{137}$. Segundo o trecho acima, o peregrino errante em terras estrangeiras desce às profundezas do inferno, pois: 1) não buscava a verdade pelo intelecto (nous) uma vez que estava preso na tentativa de fruir os corpo; 2) não confessava. Ao contrário do peregrino gnóstico, o peregrino Agostinho, segundo a identificação com a parábola bíblica, não caiu no mundo nem está aprisionado por coerção das partículas corporais de trevas. A atração para coisas corporais, sensualismo se quiser, não é de ordem corporal, pois a alma, como substância incorporal, mas mutável no tempo, é a única fonte de determinação possível do movimento ético, isso desde a criação ${ }^{138}$. Assim, a alma não está submetida ao poder do corpo, mas ela mesma deixa-se voluntariamente conduzir por ele, ou melhor, a alma posiciona-se em “região de dessemelhança” e, assim, é seduzida. ${ }^{139}$

A relação entre confissão e interioridade fica ainda mais clara no parágrafo 11 quando, através do auxílio de narrativas ficcionais, o bispo busca compreender quais teriam sido as razões de sua peregrinação juvenil.

Note-se que na estrutura do parágrafo, Agostinho expõe quatro ficções, respectivamente:

o Filho pródigo (Evangelho de Lucas 15,16)

- Voo de Medéia (Ovídio)

- Cinco antros das trevas (maniqueísmo)

quo me praestare voluisti beluis, sed secundum sensum carnis quaererem. Tradução de J. Oliveira Santos e A. Ambrósio de Pina, 1980.

${ }^{137}$ Consutar nossa análise de duab. an.

138 cf. Gn. c. man. II,12,9

${ }^{139}$ Consulte nossa análise de Sobre as Duas Almas 
- A mulher sedutora na alegoria de Salomão (Provérbios $9,17)$

As ficções repõem, não por acaso no contexto da falácia maniqueia, a discussão sobre a relação entre as palavras e a verdade, que, como vimos, depende do ponto de vista, perspectiva da qual alma parte para interpretar a letra. Faz-se a crítica à crença nas ficções maniqueia por meio da comparação com outras ficções. Tais ficções bíblicas, ainda que representem evidentemente eventos não existentes, são signos exortativos da verdade. A referência ao 'voo de Medéia' pode ser útil na medida em que há na sua falsidade algo que deleita o espírito, no entanto sua falsidade não engana, pois não gera crença ${ }^{140}$.

A ficção maniqueia é falsa e enganadora, posto que a alma do interprete não supera as palavras; ao contrário, hipostasia as percepções sensíveis resultando conceitos teológicos inaceitáveis, a saber: que Deus seja mutável, ou que a alma seja da mesma substância de Deus. Ademais, a relação entre falsidade e engano não se atém ao gênero literário, pois, no caso seguinte, as poesias ${ }^{141}$ ocupam um lugar intermediário entre a inanição das fiç̧ões maniqueias e o alimento verdadeiro das ficções bíblicas:

Pois quão melhores eram as fábulas dos gramáticos e dos poetas do que aqueles laços de engano. Porque os versos, a poesia, o voo de Medéia são bem mais úteis (utiliores) do que aquela fábula dos cincos elementos

\footnotetext{
140 conf. III, 6, 11

141 Possivelmente, Agostinho refere-se à Medeia de Ênio, tradução do original grego, que fazia parte do curriculum escolar. Ou mesmo Ovídio, Metamorph. VII 350 .
} 
(...), que não existem de maneira alguma e matam a quem neles acredita ${ }^{142}$.

Em Solilóquios 11,29, Agostinho havia desenvolvido as relações possíveis entre a verdade e ficção. Voltemos, pois, ainda que brevemente, à discussão do diálogo a fim de assentar a base da questão nas Confissões. Após as aporias que mostravam os limites da relação entre verdade e semelhança (cf. Solilóquios. II,12), o diálogo retoma a relação entre verdade e as disciplinas no parágrafo 21 e 29. Agostinho está surpreso pela Razão associar falsidade à ficção, especificamente o "voo de Medéia". Afinal, em que sentido o que absolutamente não existe, o monstro alado por exemplo, pode imitar o verdadeiro, visto que é dito verdadeiro somente o que depende e se identifica com a verdade? Trata-se de examinar qual o estatuto do falso como possibilidade de conhecimento:

R: Por acaso há alguma coisa que se diga verdade senão aquilo que por ela é verdadeiro o que há de verdadeiro? A: De modo algum. R: Acaso não se chama, com razão, verdadeiro aquilo que não é falso ${ }^{143}$

Se tudo que é verdadeiro é dito verdadeiro em razão da verdade, o falso, sendo oposto do verdadeiro, não deriva da verdade. Esse é apenas um assentimento provisório, pois é dito também que é próprio do falso manter certa semelhança com alguma coisa. Ademais, é também correto dizer que o falso afasta-se da verossimilhança, justamente porque a verossimilhança é próprio do verdadeiro. Assim, o falso é mantido numa região intermediária entre

142 conf. III,6,11 Nam versus et carmen et Medea volans utiliores certe quam quinque elementa variae fucata propter quinque antra tenebrarum, quae omnino nulla sunt et occidunt credentem.

${ }^{143}$ sol. II,XV,29 R. - Numquidnam ergo dicitur veritas, nisi qua verum est quidquid verum est? A. - Nullo modo.R. - Numquidnam recte dicitur verum, nisi quod non est falsum?. - As traduções dos Solilóquios estão cotejadas pela tradução de P. Labriolle, In: Ouvres de Saint Augustin. V. Dialogues philosophiques. Bibliothèque Augustinienne, vol V, 1948. 
semelhança e dessemelhança, pois, por um lado mantém relação com o verdadeiro por imitação; por outro, afasta-se do verdadeiro, justamente porque se afasta da verossimilhança:

R: Acaso não é falso aquilo que se assemelha a alguma coisa sem, contudo, ser aquilo a que se assemelha? A: Não vejo outra coisa a que chamar de falso. Mas costuma-se também chamar de falso aquilo que está longe da verossimelhança. R: Quem o nega? Entretanto, terá alguma imitação em relação ao verdadeiro. A: Como? ${ }^{144}$

A afirmação da Razão de que "o falso terá alguma imitação em relação ao verdadeiro" (sed tamen quod habeat ad verum nonnullam imitationem) é tão surpreendente que Agostinho propõe o caso da poesia de ficção: "Por quando se diz que Medéia voou em serpentes aladas atreladas, não há como isto imite o verdadeiro porque, por não existir, não pode imitar algo uma coisa totalmente inexistente". Em que sentido a poesia imita o verdadeiro quando o conteúdo de suas palavras não remetem a algo existente, como por exemplo, o monstro alado de Medéia? De fato, não faz sentido dizer "monstro falso", pois o monstro, que não existe, não pode imitar nada ${ }^{145}$. Logo, no caso da ficção poética, a “imitação em relação ao verdadeiro" deve estar em outro lugar:

\footnotetext{
144 sol. II, XV,29. R. - Num falsum non est quod ad similitudinem alicuius accommodatum est, neque id tamen est cuius simile apparet? A. - Nihil quidem aliud video quod libentius falsum vocem. Sed tamen solet falsum dici, etiam quod a veri similitudine longe abest.R. - Quis negat? sed tamen quod habeat ad verum nonnullam imitationem.A. - Quomodo?

${ }^{145}$ sol. II, XV,29 R. - Recte dicis; sed non attendis eam rem quae omnino nulla sit, ne falsum quidem posse dici. Si enim falsum est, est: si non est, non est falsum.A. - Non ergo dicemus illud de Medea, nescio quod monstrum, falsum esse?R. - Non utique; nam si falsum est, quomodo monstrum est?A. - Miram rem video: itane tandem cum audio: Angues ingentes alites iunctos iugo (Cicerone, De inv. 1, 19, 27)non dico falsum?R: (Tem razão. Mas não percebes que o que é totalmente inexistente tampouco se pode chamar falso? Pois se é falso existe. Se não existe, não é falso. A: Então, não sei se diremos que no relato de Medéia se trata de um monstro falso. R: Certamente não. Se é falso, como é monstro? A: É
} 
R: Certamente. Há algo que tu podes dizer ser falso. A: $\mathrm{O}$ quê? R: A sentença enunciada no próprio verso. A: Afinal, qual é a imitação que ela apresenta em relação ao verdadeiro? R: Porque ela seria enunciada do mesmo modo, ainda que Medéia realmente o tivesse feito. Portanto, uma sentença falsa, pela simples enunciação, imita sentenças verdadeiras. Se ninguém acredita nisso, ela apenas imita verdadeiras sentenças ao se expressar assim; e apenas é falsa, mas não enganadora. Mas se leva consigo credibilidade, ela imita também sentenças verdadeiras ${ }^{146}$.

A ficção poética é composta de sentenças falsas que imitam sentenças verdadeiras e, por isso, entende-se as ficções poéticas sem engano, pois é justamente por ser composta de falsas sentenças que é verdadeira ficção. Com efeito, na ficção poética, assim como em toda obra de arte, o falso e o verdadeiro se coincidem, isto é, a poesia é verdadeira enquanto falsa sentença ${ }^{147}$. Ao contrário da ficção poética, a ficção maniqueia é enganadora, porque o maniqueu não reconhece a falsidade das sentenças: “E se ninguém acredita nisso, ela apenas imita verdadeiras sentenças ao se expressar assim; apenas é falsa, mas não enganadora. Mas se ela requer a fé, então também imita sentenças verdadeiras que são cridas"148.

A forma argumentativa dos Solilóquios não deve levar o leitor a pensar que o engano maniqueu seja de ordem lógica. Em Sobre o Mestre, Agostinho deixa claro a dependência da disposição

\footnotetext{
estranho. Acaso quando ouço: "Imensas serpentes aladas por um jugo atreladas", não digo que isso é falso?)

146 sol. II, XV,29 R. - Dicis plane: est enim quod falsum esse dicas.A. - Quid, quaeso? R. - Illam scilicet sententiam quae ipso versu enuntiatur: A. - Et quam tandem habet ista imitationem veri? R. - Quia similiter enuntiaretur, etiamsi vere illud Medea fecisset. Imitatur ergo ipsa enuntiatione veras sententias falsa sententia. Quae si non creditur, eo solo imitatur veras quod ita dicitur, estque tantum falsa, non etiam fallens. Si autem fidem impetrat, imitatur etiam creditas veras

147 cf. sol. II,X,18

148 sol. II, XV,29 Quae si non creditur, eo solo imitatur veras quod ita dicitur, estque tantum falsa, non etiam fallens. Si autem fidem impetrat, imitatur etiam creditas veras.
} 
do espírito, boa ou má vontade, como elemento orientador de "consulta" à verdade ou ao engano:

No que diz respeito a todas as coisas que compreendemos, não consultamos a voz de quem fala, a qual soa por fora, mas a verdade que dentro de nós preside à própria mente, incitados talvez pelas palavras a consultá-la. Quem é consultado ensina verdadeiramente, e este é Cristo, que habita, como foi dito, no homem interior, isto é: a virtude incomutável de Deus e a sempiterna Sabedoria, que toda alma racional consulta, mas que se revela a cada um quanto é permitido pela sua própria boa ou má vontade. E se às vezes há enganos, isto não acontece por erro da verdade consultada, como não é por erro da luz externa que os olhos, volta e meia, se enganam: luz que confessamos consultar a respeito das coisas sensíveis, para que no-las mostre na proporção em que nos é permitido distingui- las $^{149}$.

O engano, portanto, deriva do auto posicionamento da alma, segundo sua boa ou má vontade em relação à verdade consultada. A verdade, a bem dizer, deve ser consultada, e ela mesma não engana. O grau de verdade compreendida (capere) depende da disposição do espírito. Nas Confissões, conforme temos demonstrado, a relação entre engano e as condições de verdades ou falsidades das ficções são o pano de fundo da falácia maniqueia ${ }^{150}$.

\footnotetext{
149 de mag. XI,38 De universis autem quae intellegimus non loquentem qui personat foris, sed intus ipsi menti praesidentem consulimus veritatem, verbis fortasse ut consulamus admoniti. Ille autem qui consulitur, docet, qui in interiore homine habitare dictus est Christus, id est incommutabilis Dei Virtus atque sempiterna Sapientia (Efésios 3,16-17): quam quidem omnis rationalis anima consulit; sed tantum cuique panditur, quantum capere propter propriam, sive malam sive bonam voluntatem potest. Et si quando fallitur, non fit vitio consultae veritatis, ut neque huius, quae foris est, lucis vitium est, quod corporei oculi saepe falluntur: quam lucem de rebus visibilibus consuli fatemur, ut eas nobis quantum cernere valemus, ostendat. Tradução de Angelo Ricci, 1973

150 Seria oportuno investigar as relações entre autoridade e verdade no contexto das ficções bíblicas, pagã e maniquéia. Por razões de extensão de nossa dissertação, não enfrentaremos aqui tal questão. Deixamos, contudo, indicado que a primeira frustração do jovem estudante como a doutrina maniqueia, em Confissões V, ocorreu no encontro com Fausto, bispo maniqueu, que se mostrou inábil em ciências.
} 
Assim como foi indicado no diálogo, que a origem do engano é de ordem interior, também o será o engano pela crença ${ }^{151}$.

Esse é obviamente o caso da crença nas ficções maniqueias, segundo o parágrafo das Confissões, que retomamos:

Porque dos versos, da poesia eu poderia transformar em prazeroso alimento, e mesmo quando recitava o Voo de Medéia não dava meu assentimento; e se ouviao declamado, não acreditava. Mas naquelas coisas, eu $\mathrm{cri}^{152}$.

Agostinho expõe a crença nas ficções maniqueias a partir de outra ficção:

Encontrei aquela mulher audaz e desprovida de prudência, que na alegoria de Salomão está sentada sobre a cadeira, fora de casa, à porta, (foribus) e diz: comei à vontade e livremente os pães escondidos, e bebei as doces águas roubadas (Provérbios 9,17). Essa [mulher] me seduziu, porque me encontrou fora, habitando no olho de minha carne, e ruminando dentro de mim (apud me) aquelas coisas que pelo olho eu tinha devorado ${ }^{153}$.

De início, é preciso perceber que combater a falácia da ficção maniqueia com outra ficção pode ser arriscado, pois alguém pode pensar que seria mais seguro combater a crença na falsidade da ficção, recusando a própria ficção. Mas Agostinho parece insistir na tese de que não se trata tanto do gênero literário, mas ao auto

${ }^{151}$ Consultar E. Bermon. La signification. p. 467; Bermon indica outras passagem onde Agostinho reafirma a relação entre verdade e disposição do espírito (vontade), i.e. vera relig. 3,3; ut. cred. 16,34.

152 conf. III,6,11 Nam versum et carmen etiam ad vera pulmenta transfero; volantem autem Medeam etsi cantabam, non asserebam, etsi cantari audiebam, non credebam: illa autem credidi. Tradução de J. Oliveira Santos e A. Ambrósio de Pina, 1980.

153 conf. III,6,11 Offendi illam mulierem audacem, inopem prudentiae, aenigma Salomonis, sedentem super sellam in foribus et dicentem: Panes occultos libenter edite et aquam dulcem furtivam bibite. Quae me seduxit, quia invenit foris habitantem in oculo carnis meae et talia ruminantem apud me, qualia per illum vorassem. Tradução de J. Oliveira Santos e A. Ambrósio de Pina, 1980. 
posicionamento da alma em relação ao texto. A própria ficção bíblica aponta para tal conjuntura. A mulher sedutora da alegoria de Salomão está sentada sobre a cadeira, fora de casa (foribus). Mas o mais importante é saber onde Agostinho está ou estava? E ele mesmo perguntava-se no início do parágrafo, identificando-se ao pródigo do evangelista Lucas. "Onde eu estava? E onde Tu estavas?". A crença é uma sedução, possibilitada por uma situação exterior ocasionada por auto posição da vontade. Agostinho assume total responsabilidade pela sedução, pois a "ruminação corporal" que mantém a alma estacionada no corpo, sem superação da exterioridade, é um ato do espírito e não uma coerção do corpo sobre o espírito ${ }^{154}$. Pois "não é o corpo corruptível que tornou a alma pecadora, mas a alma pecadora que tornou o corpo corruptível"155. Com isso, o corpo é salvaguardado de qualquer instância de mal, ao mesmo tempo que assenta sob a alma toda a questão da corrupção. Portanto, ao assumir a responsabilidade pela sedução, isto é, ao deslocar a questão do engano ou do pecado para o regime de interioridade, precisamente a alma, Agostinho adianta a questão da culpabilidade do pecado posta no livro $V$ das Confissões, sob a qual baseia-se o dogma gnóstico das duas almas. Como o próprio título do dogma alude, o problema agora passa a ser a alma. Obviamente, não

154 Consulte L. Mammì sobre a originalidade de Agostinho em relação ao sensualismo do espírito (indivíduo), no cristianismo, em resposta à tradição filosófico-grega. Segue a sugestão de Kierkegaard que vê no Eros a representação do desejo não encarnado, como desejo exterior (corpo) não individualizado e contrário ao espírito. De outro lado, o cristianismo encarna o desejo no espírito a fim de expulsá-lo. Nessa relação de negação e interiorização, o sensualismo se constitui como "determinação do espírito" ou como "espírito na carne". Consultar Lorenzo Mammì. O que Resta. cap. V O Espírito na carne (cristianismo, corpo e imagem). Companhia das Letras, 2012, p. 121. Também, do mesmo autor: Agostinho e as artes : dos diálogos filosóficos às Confissões. Livre docência, USP. São Paulo, 2009

155 civ. Dei XIV, III, apud Mammì, opera supra cit., p. 121 
uma alma isolada em torre de marfim, mas uma alma medianamente situada e espantosamente adoecida pelo pecado (miris morbis ${ }^{156}$ ).

\section{I,3 A gnose resiste: sobre as duAs almas (DISCURSO RACI ONAL)}

\section{I,3,1 VERDADE E SER}

Até aqui temos acompanhado como Agostinho analisa seu movimento à gnose maniqueia enquanto percorre sua narrativa pessoal. O bispo reconhece tanto sua semelhança à Deus quanto sua dessemelhança. Semelhança e dessemelhança que estão associadas à alma que se eleva a Deus ou rebaixa-se na tentativa de realizar-se no corpo; falácia de representações sensíveis naturalizadas em realidades que no fundo não passam de simulacro e imaginação vazia. Destarte, quando se procura pela causa do engano, Agostinho afirma que não o encontrará em outro lugar senão na própria dinâmica interna da alma.

Passa-se a examinar a própria natureza da interioridade que, embora insinuada e pressuposta, ainda não foi desenvolvida. Será a partir de $111,7,12$, no contexto da questão acerca da proveniência do mal (unde malum), que as naturezas, tanto de Deus quanto da alma, tornam-se tema principal. Vejamos como Agostinho encadeia o conceito que podemos chamar, seguindo G. Madec, de espiritualismo agostiniano157: “Eu ignorava a outra realidade, a verdadeira, e era levado a aceitar o que me parecia o penetrante

\footnotetext{
${ }^{156}$ cf. duab. an. IX, 11

157 Madec, G. Conversion, Le Spiritualisme Augustinen. In: Petites Études Augustiniennes. 1994
} 
raciocínio de estúpidos impostores, quando me faziam perguntas sobre a origem do mal"158.

A busca pelo que realmente é ou por aquilo que é verdadeiramente (vere quod est) coloca verdade e ser sobre o mesmo plano. Quando o procedimento corporalista ignora a realidade inteligível, cai em projeções antropomórficas de Deus a ponto de imaginá-lo com cabelo ou qualquer outra característica corporal humana. Todavia, se os inteligíveis existirem verdadeiramente (vere), a falsidade das projeções corporais não passam de ilusões enganadoras e, consecutivamente, a natureza de Deus em nada depende dos corpos:

Pois eu não sabia que o mal é apenas privação do bem, privação esta que chega ao nada absoluto. Mas teria podido conhecer a verdade, se meus olhos só atingiam o meu corpo e meu espírito não via mais do que fantasias (phantasmata)? Não sabia que Deus é espírito $^{159}$.

Reduzir a verdade à representação corporal, portanto, é enganar-se, uma vez que o conhecimento de Deus e da alma tornase apenas um pseudo saber de corpos que acaba por afastar o homem do verdadeiro conhecimento, a saber, que "Deus é espírito". Ainda mais, faz da mente humana criadora de fantasias fictícias ${ }^{160}$ (phantamasta) a partir das quais o mal é naturalizado; mas o mal, da perspectiva de quem conhece o criador Deus como ser espiritual, pode ser dito "mal" apenas no sentido defectível, ou seja, como privação de bem sem natureza ontológica.

\footnotetext{
158 conf. III,7,12 Nesciebam enim aliud, vere quod est, et quasi acutule movebar, ut suffragarer stultis deceptoribus, cum a me quaererent, unde malum

159 conf. III, 7,12 Quibus rerum ignarus perturbabar et recedens a veritate ire in eam mihi videbar, quia non noveram malum non esse nisi privationem boni usque ad quod omnino non est. Quod unde viderem, cuius videre usque ad corpus erat oculis et animo usque ad phantasma? Et non noveram Deum esse spiritum. III,7,12. Tradução de Maria L. J. Amarante. Alterações e grifo nossos.

${ }^{160}$ Consultar epist. VIII
} 
No livro VII das Confissões, Agostinho retoma a questão da verdade e identidade com mais detalhes:

E observei as restantes coisas abaixo de ti e vi que nem em absoluto são, nem em absoluto não são: na verdade, são, por que procedem de ti, mas não são, porque não são aquilo que tu és. Porque isto que é verdadeiramente é o que permanece imutavelmente ${ }^{161}$

Então, todas as coisas criadas não podem ser absolutamente, nem podem não ser absolutamente. O mundo é concebido sobre uma cadeia progressiva de entes com mais ou menos imutabilidade, com mais ou menos essências. Portanto, a rigor, só existe um ser que "é verdadeiramente", em absoluto, que não sofre alteração, logo não pode ser corpo: "Deus é espírito".

Tendo Deus como o Ser espiritual supremo e sumamente bom, poderá dizer que tudo o que existe é bom, porque toda a substância foi criada do nada (ex nihilo) por Deus que é o supremo bem. Assim, a pergunta "de onde vem o mal?" permanece, mas ganha nova perspectiva. Se tudo que existe é bom, pois tem essência em alguma instância, então, o mal não poderá ser substância. Resta colocar o mal num estatuto de corrupção daquilo que é, o que significa dizer que o mal é privação. Evidentemente, tal desenvolvimento eliminará a possibilidade de Deus como causa do mal. No entanto, o pecado permanece como presença desconcertante à ontologia hierarquizada. Agostinho fará a passagem da ontologia para a ética.

$E$ indaguei o que seria a iniquidade, e não encontrei que fosse uma substância, mas sim a perversidade de

${ }^{161}$ cf. conf. VII, 11, 17: Et inspexi cetera infra te, et vidi nee omnino esse nee omnino non esse: esse quidem, quoniam abs te sunt, non esse utem, quoniam id quod es non sunt. id enim vere est, quod incommutabiliter manet. 
uma vontade, que se desvia da suprema substância, de ti, que és Deus, para as coisas ínfimas, e que lança de si o que tem no seu íntimo e intumesce por fora. ${ }^{162}$

O mal passa a ser pecado (iniquitas), ou seja, trata-se de um mal moral, de modo que não se trata de investigar acerca da essência do mal, mas de onde ele vem. É um importante deslocamento, em que o problema não é mais o mal, mas eu mesmo. Agostinho, então, torna-se uma "grande questão a si mesmo"; passa a interrogar a própria alma ${ }^{163}$ em busca de respostas. Pergunta-se, afinal, o que é essa dinâmica interior da alma cujo deleite e atenção (curae) movimentam todo o ser? Fato é que a vontade livre poderá querer se afastar do supremo bem e assim o faz.

Dado que se entende o mal como privação do bem ${ }^{164}$ interior, uma perversão da vontade que, em razão de sua autonomia, é capaz de dirigir-se para o afastamento do supremo bem, resta pensar como o pecado se dá no interior da alma. Não se pensa mais o que é o mal, mas como como o homem peca e qual o alcance da absoluta indeterminação da vontade interior.

\section{I , 3,2 Pecado e culpabi li dade}

O deslocamento do mal para o interior do homem abrirá uma nova investigação, a saber, a relação entre origem do pecado ${ }^{165}$ e culpabilidade:

\footnotetext{
162 cf. conf. VII, 16, 22: et quaesivi, quid esset iniquitas, et non inveni substantiam, sed a summa substantia, te deo, detortae in ínfima voluntatis pervesitatem proicientis intima sua et tumescentis foras.

163 cf. conf. IV, 4,9 Factus eram ipse mihi magna quaestio et interrogabam animam meam

${ }^{164}$ Ver Madec, Goulven, Nihil' cathare et 'nihil' augustinien, In : Revue des Etudes Augustiniennes 1977, 92-112.

${ }^{165}$ Veremos como o conceito do pecado orginal aparecerá no final do tratado duab. an.
} 
No entanto, eu continuava em Roma a frequentar os chamados santos enganados e enganadores, e não só os seus "ouvintes"(...) mas também os chamados "eleitos". Conservava ainda a ideia de que não éramos nós que pecávamos, mas alguma outra natureza estabelecida em nós. O fato de estar sem culpa e de não dever confessar o mal após tê-lo cometido satisfazia o meu orgulho; desse modo eu não permitia que curasses minha alma que pecara contra ti preferindo desculpá-la e acusar não sei qual outra força, que estava em mim, mas que não era eu ${ }^{166}$.

Em Roma, a relação entre pecado e culpabilidade permanece como a última questão que Agostinho deve enfrentar para superar a seita gnóstico-cristã. Na verdade, essa relação é a base de uma particular polêmica no seio das doutrinas gnósticas ${ }^{167}$. Trata-se da polêmica sobre as duas almas, a respeito da qual o presbítero de Cartago dedicará todo um tratado, em 392.

Passaremos a analisar o tratado a seguir, mas antes vale dispor de alguns elementos, ainda que gerais, conforme descrito no livro $V$ das Confissões. Com isso, apresentaremos algumas considerações finais do retrato da fase maniqueísta que Agostinho deixou em sua narrativa; ao mesmo tempo apresentamos alguns traços do problema que nortearão a nossa leitura do tratado de 392.

De partida, note-se nessa retomada da questão maniqueia já não se enfatiza tanto as palavras como veículo do engano quanto se fazia no livro III. Trata-se de elucidar a relação entre pecado e culpa a partir da experiência pessoal de fracasso moral.

\footnotetext{
${ }^{166}$ conf V, 10,18 Et iungebar etiam tunc Romae falsis illis atque fallentibus sanctis: non enim tantum auditoribus eorum, (...), in cuius domo aegrotaveram et convalueram, sed eis etiam, quos electos vocant. Adhuc enim mihi videbatur non esse nos, qui peccamus, sed nescio quam aliam in nobis peccare naturam et delectabat superbiam meam extra culpam esse et, cum aliquid mali fecissem, non confiteri me fecisse, ut sanares animam meam, quoniam peccabat tibi $\underline{69}$, sed excusare me amabam et accusare nescio quid aliud, quod mecum esset et ego non essem

167 Consultar Ferwerda. Origen's and Augustine's Attitude toward the Two Souls Doctrine. In: Vigilae Christianae, 1983
} 
A confiança de Agostinho no mito dogmático maniqueu sofre um duro golpe quando o estudante encontra Fausto, o maniqueu. A frustração diante da constatação da incompetência nas disciplinas liberais $^{168}$ revela não somente a falibilidade de um indivíduo, mas principalmente expõe a fraqueza de um modelo de conhecimento (gnosis) baseado na pretensão do discurso racional que ousa naturalizar ao último nível a experiência sensível e moral do pecado $^{169}$.

Há na gnose, conforme as palavras de Cambronne, que segue as orientações de Puech e Hans Jonas, uma insistência em "explicar em toda lógica a experiência íntima do mal":

A experiência íntima do Mal dejá-lá implica uma protohistória do Mal. Porque é exatamente disso que se trata o mito dos Três Tempos. Mesmo uma leitura pouca atenta do 'Segundo Tempo' nos mostra bem que a criação do mundo não intervém senão ao termo da 'Primeira Guerra', ao curso daquilo já era operada na mistura entre as duas substâncias.

O que isso quer dizer senão que a história da humanidade somente pode ser explicada em toda lógica por uma proto-história do Mal e da Salvação que serve de modelo a uma tripla função: etiológica, arquetípica e exemplar? Não se encontraria um modo de reflexão tentador para o espírito humano em busca de racionalidade? ${ }^{170}$

\footnotetext{
168 cf. conf. V, 6,11

169 cf. conf. $V, 7,12$

170 'L'experience intime du Mal déjá-lá implique une proto-histoire du Mal. Car c'est bien de cela qu'il s'agit dans le Mythe de Trois Temps. Une lecture tant soit peu attentive du 'Deuxième Temps' nous montre bien qu'en fait la création du monde n'intervient qu'au terme de la première guerre au cours de laquelle que l'histoire de I'humanité ne peut s'expliquer en toute logique que par une protohistoire du Mal et du Salut qui lui sert de modèle, à triple fonction, étiologique, archétypale et exemplaire? Me retrouve-t-on pas là une démarche réflexive, tentante pour l'esprit humain en quête de rationalité'. Cambronne, Patrice. Augustin et l'Église : Jalons d'un itinéraire, 1989. p. 30
} 
Ainda que a crença nas ficções maniqueias estivesse abalada, Agostinho parece estar apegado a algo da doutrina que explicasse a insistência de uma experiência moral fracassada (na gnose, o mal dejá-lá), que solapa as esperanças de uma potência de bem querer, ou mais ainda, como diz Marion de querer inteiramente, potência de "querer querer".

Esse "mal dejá lá que implica uma proto história do mal" parece responder parcialmente à relação espinhosa entre pecado e culpabilidade, na medida em que reconhece uma situação não provocada individualmente, mas partilhada na tragicidade cósmica. É exatamente essa experiência fracassada da vontade que pode ser encontrada no mito gnóstico sobre as duas almas. Decret descreve a tragicidade do mal como estado de alienação iniciada na mescla de duas almas: "a alma está mergulhada numa situação que ela não provocou... O fato que ela seja marcada para esta 'alienação' não constitui contudo um pecado, contrariamente ao que pretende Agostinho"171. Mas esse estado de "entenebrement"172, diz Decret, ainda não é pecado, porque foi mais trágico do que voluntário. Em Agostinho, a origem da condição humana já é pecado, o que de fato é paradoxal, pois se, por um lado, o estado de alienação é provocado exclusivamente pela vontade individual; por outro, Agostinho parece resistir à culpabilidade de sabor voluntarista ou, como diria Ricoeur, vontade individual "sem bagagens e sem hábitos".

Como o último bastião da gnose, a doutrina sobre as duas almas, a nosso ver, marca um estado intermediário do tratamento que Agostinho dá ao pecado. O mito gnóstico sobre as duas almas

\footnotetext{
171 Decret, Aspects Du Manichéisme Dans L'Afrique Romaine, 1970, p. 339 “L'âme est plongée dans une situation qu'elle n'a pas provoqueée ... Le fait qu'elle soit marqueé pour cette «allienation» ne constitue cepandant pas un peche, contrairement à ce que prétend Augustin".

172 em-trevas-amento : alma boa englobada como por fagocitose.
} 
parece reconhecer que o homem peque por alguma potência na alma. Assim, para o hiponense a alma má, que não é ser, seria apenas símbolo da missão moral de aprender por experiência (discit experiendo ${ }^{173}$ ) fracassada (mal dejá lá ${ }^{174}$ ). O fracasso não pode ser naturalizado, mas deve ser descrito como experiência de culpa pessoal. Recusa-se o mal cósmico e natural, mas a verdade do símbolo é mantida no reconhecimento do pecado proto histórico, dejá lá (original).

De início, a doutrina das duas almas causa um curto circuito na doutrina de um mal cósmico, pois evidenciam-se incoerências internas decorrentes de internalização da vontade em conjunto com o dualismo de duas substâncias polares. Inconsistência interna que leva Puech e outros a recusarem a historicidade do dogma gnóstico. Decret, contudo, surpreende ao defender a existência da doutrina das duas almas no maniqueísmo. Para ele, haveria no mito um fenômeno legítimo de interiorização da vontade, ainda que se entenda a alma como corpórea. Consequentemente, Agostinho teria perdido a verdade contida no mito, a fim de derruir todo o corpo doutrinário do mito dogmático, uma vez que o mito sobre as duas almas indicaria que a luta cósmica da gnose teria sua realidade reproduzida na interioridade da alma. A proposta de leitura de Decret é interessante e improvável, pois parece pretender ver no maniqueísmo, anacronicamente, uma vontade cindida própria de um Agostinho do livro VIII das Confissões. Sem entrar no debate, é suficiente marcar que, tendo existido a doutrina conforme o testemunho de Agostinho em Sobre as Duas Almas, o pecado na gnose estende-se da tragicidade carnal para tragicidade anímica. Na doutrina gnóstica

\footnotetext{
173 Consultar nossa introdução, em que analisamos Gn. c. man. II,9,12 - Situação mediana da alma

${ }^{174}$ Consultar nossa introdução sobre Verdade e mito: a gnose anti-gnóstica.
} 
sobre as duas almas o pecado é experiência mundanizada de uma realidade trágica de duas almas ${ }^{175}$.

Uma alma má, "outra natureza estabelecida em nós", como já disse Agostinho em Confissões III, 7,12, que é o paralelo real e espelhado de um mal universal ${ }^{176}$. A partir desse mal físico “interiorizado", F. Decret interpreta o dogma maniqueu sobre as duas almas como a explicação mítica da gnose acerca da origem do pecado: "tendo o homem sido formado à imagem de duas Potências adversas $^{177}$, a busca pela gênese do pecado consiste em investigar essa mistura (commixtio)"178. Dessas descobertas acerca do fenômeno gnóstico-maniqueu, não demoraria muito para que se fizessem associações entre a origem do pecado na gnose e seu impacto na explicação da origem do pecado em Agostinho ${ }^{179}$, o que por sua vez aponta para, além da crítica materialista antimaniqueia, certa presença e apropriação da gnose.

\footnotetext{
175 No caso do maniqueísmo, a alma é espírito limitado e Deus é espírito de corpo infinito. cf. Decret, Aspects Du Manichéisme Dans L'Afrique Romaine, 1970, p. 326 seq.

176 cf. Decret, Aspects Du Manichéisme Dans L'Afrique Romaine, 1970, p. 326.

177 cf. de natura boni 46 (espist. fundamenti)

178 Decret, Aspects Du Manichéisme Dans L'Afrique Romaine, 1970, p.337

179 cf. Decret, opera cit., p. 339; Van Oort. Manichaeism: its sources and influences on western christianity, In: Verbum et Ecclesia 2009, p. 129; Van Oort, J., 1989, 'Augustine on sexual concupiscence and original sin', In: Studia Patristica XXII, p. 382
} 


\section{PARTE I I}




\section{Parte I I - Sobre as Duas Almas}

\section{I ,1 I NTRODUÇÃo}

Sobre as Duas Almas foi escrito entre 391 e 392, logo nos primeiros anos de seu presbiterado em Cartago ${ }^{180}$. O tratado antimaniqueu, apesar de pouco conhecido, tem sido recentemente citado por estudiosos tanto do maniqueísmo quanto em pesquisas agostinianas. Os primeiros estarão mais interessados na reconstrução do maniqueísmo, que, quanto ao presente dogma, tem em Agostinho ainda sua principal fonte. Para esses estudiosos, dos quais citamos François Decret, J. Ries, H.-C. Puech, G. Quispel, Hans Jonas e outros, é ampla e polêmica a questão de se saber se realmente houve uma doutrina das duas almas tal como Agostinho a descreve neste tratado, visto que se carece de fontes documentais que a comprovem $^{181}$. Dentre os estudos agostinianos, citamos publicações recentes de Wetzel e Babcock $^{182}$, que buscarão nesse livro um

180 cf. retr I 14. Agostinho nos informa que a obra foi escrita quando era presbítero, portanto posterior a primavera de 391 e anterior aos últimos meses de 395, quando já era bispo. Mais precisamente, pode-se pensar que seu término se deu em 392, meses antes do debate contra Fortunato e depois da produção da Utilidade da Crença (Utilitate Credendi). Assim, o tratado deverá ter sido escrito precisamente entre o verão de 391 e o verão de 392. Consultar também as introduções ao livro e aos escritos anti-maniqueus em geral: Jolivet, in Bibliotheque Augustinienne v.17; e Roland Teske in The Manichean Debate, New City Press. New York, 1990;

${ }^{181}$ Para uma discussão recente entre as provas textuais históricas da existência do dogma das duas almas na antiguidade tardia, consulte-se R. Ferwerda, Two Souls. Origen's and Augustine's Attitude toward the Two Souls Doctrine. Its Place in Greek and Christian Philosophy Vigiliae Christianae Vol. 37, No. 4 (Dec., 1983), pp. 360378; Ferwerda apoia-se em rica documentação de antigos textos para defender a existência do dogma tal como Agostinho o descreve. Opõe-se a tese de Decret, Franc,ois. Aspects Du Manichéisme Dans L'Afrique Romaine: Les Controverses De Fortunatus, Faustus, Et Felix Avec Saint Augustin. Paris: Études augustiniennes, 1970.

182 Cf. Wetzel, James. Augustine and the Limits of Virtue. Cambridge [England] ; New York, NY, USA: Cambridge University Press, 1992. e Babcock, William. Review. Images of Conversion in Augustine's Confessions by Robert J. O'Connell . Church History, Vol. 67, No. 1 (Mar., 1998), pp. 124-126. Babcock enfatiza o debate contra os maniqueus ocorrido em 391 como primeiro indício de inflexão da noção de vontade no contexto do hábito: "developments in Augustine's thinking about the will's bondage to habit (consuetudo), and therefore about the working of God's 
primeiro indício de transição entre uma primeira fase, mais otimista e voluntarista quanto à potência ética do homem, e uma segunda, baseada no reconhecimento da limitação moral (chamam de pecado involuntário $^{183}$, progredindo para a doutrina do pecado original) já consolidada nas Confissões. Na verdade, ambos partem da obra de Alflatt $^{184}$ (1974) que explora a "culpabilidade do que não é voluntário"185, principalmente nas obras agostinianas entre 391 e 393. Alflatt, no entanto, cita Sobre as Duas Almas em fase anterior ao que denomina "pecado involuntário", perante o qual Wetzel e Babcok divergem, pois percebem no tratado de 391 o primeiro indício de uma insuficiência da vontade.

Esses parecem concordar com o testemunho de Peter Brown (1967):

Agostinho passaria vorazmente de um problema ao outro: o que talvez houvesse começado como a perigosa desilusão de um perfeccionista emergiu, nas Confissões, como uma nova visão do homem, uma reavaliação de suas potencialidades, uma descoberta empolgante e profunda das verdadeiras fontes de suas motivações (...). Podemos ver essa consciência impondo-se a ele quando padre, especialmente nos

\footnotetext{
grace, that began in his works On Two Souls (391) and Against Fortunatus (392) and that represent another sharp break between his outlook at Cassiciacum and his outlook in the Confessions.". grifo nosso. Nossa dissertação deverá demonstrar esse "sharp break". Não faremos, contudo, uma análise transversal das obras no período que compreende Cassicíaco ao presbiterado de Cartago; antes, prentedemos esclarecer como as principais linhas de força que estão por trás dos conceitos são gradativamente elaboradas para enfrentar problemas emergidos do combate contra a gnose.

183 Wetzel, op. cit., p. 97 "The connection between Adam's voluntary sin and the involuntary sins of his descedants is admittedly mysterious, and it is difficult to understand how the notion of voluntary sin gains any futher clarity by virtue of its retriction to an original agente." (grifo nosso).

184 cf. Alflatt, Malcom. The Development of the Idea of Involuntary Sin in St. Augustine. Études Augustiniennes, 1974. Também: Alflatt, Malcom. Responsibility for Involuntary Sin in Saint Augustine. In: Recherches Augustiniennes. vol. 101975 ${ }^{185}$ Cf. Alflatt, op.cit., 1974, p. 116
} 
textos que escreveu contras os maniqueístas, entre 392 e $394^{186}$.

De fato, a questão da inflexão cristã em Agostinho remonta para bem antes de Brown ou Courcelle. Em 1897, conforme aponta F. Lossl $^{187}$, L. Loofs já indicava 391 como o ano em que se inicia gradativa inserção de elementos cristãos no pensamento do hiponense, remodelando sua “conversão" platônica inaugurada pelo encontro com quosdam libros platonicorum em 386. Opinião que não demorou para ser refutada já em 1908, quando Thime discordaria severamente: "Augustine's conversion to Christianity was still far from being completed [in 391]"188.

Não se trata de reviver tão antiga polêmica dos estudos agostinianos, mas sim de localizar o tratado, Sobre as Duas Almas, justamente nesses textos escritos contra os maniqueus em 391-392, a fim de chamar a atenção para a necessidade de se manejar argutamente o instrumental filosófico de sua tradição.

A nós, diante da limitação de extensão da nossa dissertação, interessa menos a evolução no quadro geral do pensamento de Agostinho do que atentar, conforme anunciamos, para a imbricação da dupla orientação do pecado: eticidade e tragicidade. Em plano mais geral, trata-se da difícil discussão filosófica acerca da relação entre imanência e transcendência no interior da filosofia agostiniana, que insiste no caráter racional do

${ }^{186}$ Brown, Peter. Santo Agostinho: uma biografia. Editora Record. Rio de Janeiro, 2008. p. 182; .

187 cf. F.LOOFS, art Augustinus, Realenzyklopaedie für protestantis che Theologieund Kirche II, Leipzig 1897, 257 ff ; apud LOSSL, Josef. The One (unum) - A guiding concept in De vera religione. In : Revue d'Etudes Augustinienne,40, 1944 , p. 81

188 W.THIMME, Augustins geistige Entwicklung in den ersten Jahren nach seiner Bekehrung 386-391, Berlin1908,254., apud LOSSL (1944) 
homem, ao mesmo tempo em que se vê necessariamente comprometida com a alteridade do divino face à finitude humana.

Talvez, a forma mais sucinta de introduzir a particular doutrina maniqueia sobre as duas almas seja evocar o próprio texto de Agostinho, o A Verdadeira Religião (390), escrito aproximadamente um ano antes que Sobre as Duas Almas, quando o autor esboçara o princípio maniqueu das duas almas, prometendo maior desenvolvimento no futuro, o que realmente se deu:

9.16. Creio, com a ajuda de Deus, que este texto, precedido pela piedade, possa servir aos bons leitores contra não somente um erro, mas contra todos os erros e opiniões falsas. Mas o texto é dirigido principalmente contra aqueles que julgam existir duas naturezas ou substâncias de princípios distintos, que lutam uma contra outra. Pelo fato de algumas coisas ofenderem, e outras deleitar querem eles que Deus seja o autor não do que os aborrece, mas somente do que lhes agrada.

$\mathrm{E}$, como não podem vencer seu hábito, prisioneiro dos laços carnais, estimam que em um corpo existam duas almas: uma de Deus, que por natureza seria como ele; outra, da raça das trevas, a qual não seria criada por Deus, que não a fez, não a produziu e não a descartou. Essa alma, porém, teria sua própria vida, sua terra, suas produções e animais. Enfim, possuiria seu reino e um princípio não-criado. Em algum momento, ela teria se rebelado contra Deus, que não tendo o que fazer e nem encontrando alguma maneira de resistir a essa hostilidade, sendo levado pela necessidade, teria enviado aqui uma alma boa e alguma partícula de sua própria substância que por amálgama e mistura segundo deliram- teria suavizado a força hostil e fabricado o mundo. 
(9.17) Por enquanto, não refutemos essas teorias, que em parte já fizemos; façamos a refutação do restante à medida em que Deus nos permitir ${ }^{189}$

\section{Agostinho está preocupado em combater as falácias}

(falsas opiniones) em geral, mas dedica especial atenção aos maniqueus, cujo dogma descreve como "o combate de substâncias de princípios contrários". Dado que dessas duas substâncias, uma causa ofensa, a outra, prazer, e sendo Deus autor apenas da substância prazerosa, resulta que a outra substância não é criada por ele, mas está misturada na sua criação desde o ataque das trevas. O mundo é fruto dessa mistura ${ }^{190}$, uma origem trágica em que Deus foi obrigado a ceder sua própria substância ao domínio das trevas.

\footnotetext{
${ }^{189}$ de vera relig. 9,16. Credo autem affuturum Deum, ut ista scriptura, praecedente pietate, legentibus bonis, non adversus unam aliquam, sed adversus omnes pravas et falsas opiniones possit valere. Contra eos tamen potissimum est instituta, qui duas naturas vel substantias singulis principiis adversus invicem rebelles esse arbitrantur. Offensi enim quibusdam rebus, et rursus quibusdam delectati, non earum quibus offenduntur, sed earum quibus delectantur, volunt esse auctorem Deum. Et cum consuetudinem suam vincere nequeunt, iam carnalibus laqueis irretitam, duas animas esse in uno corpore existimant: unam de Deo, quae naturaliter hoc sit quod ipse; alteram de gente tenebrarum, quam Deus nec genuerit, nec fecerit, nec protulerit, nec abiecerit; sed quae suam vitam, suam terram, suos fetus et animalia, suum postremo regnum habuerit, ingenitumque principium; sed quodam tempore adversus Deum rebellasse, Deum autem qui aliud quod faceret non haberet, et quomodo aliter posset hosti resistere non inveniret, necessitate oppressum misisse huc animam bonam, et quamdam particulam suae substantiae, cuius commixtione atque miscela hostem temperatum esse somniant, et mundum fabricatum. 9.17. Neque nunc opiniones eorum refellimus, quod partim iam fecimus, partim quantum Deus siverit faciemus grifo nosso.

190 Puech In Histoire des Religion II, p. 554 "O maniqueísmo, no entanto, se tomado como oposição levada ao extremo, enrijecendo essa oposição naqueles dois princípios radicalmente distintos, o Bem por um lado e o Mal pelo outro, o fará em diferente operação ou interpretação: para ele (Mani), o responsável da queda, da catástrofe que está na origem do mundo material e conseguinte infelicidade que submeteu a humanidade, é justamente o "Príncipe das Trevas", mas a organização deste mundo onde se misturam os elementos bons e elementos maus, o caráter provisório que ela representa é a obra de entidades emanadas do Deus supremo".(Le manichéisme, toutefois, s'il pousse l'opposition à l'extrême, en la durcissant en celle de deux principes radicalment distincts, I'un du Bien et l'autre du Mal, l'exploitera ou l'interpretra différemment : pou lui, le responsable de la chute, de la castratofe qui est à l'origine du monde matériel et de la suite de malheurs qu'y subit I'humanité, est bien le « Prince des Ténèbres », mais l'organization de ce monde où se mêlent éléments bons et éléments mauvais, les pis-aller qu'elle représente, est l'ouvre d'entités émanées du Dieu suprême).
} 
O dogma das duas almas, anunciado na segunda parte de nossa divisão do parágrafo, é um caso particular da teoria geral das duas substâncias contrárias. Segue coerentemente a mesma dicotomia substancial do mundo, um dualismo microcósmico ${ }^{191}$ que pretende explicar os móbiles humanos, pois o hábito carnal que escraviza os maniqueus é a causa deles terem "estimados que em um corpo existam duas almas."

Vale, sobretudo, marcar que as linhas gerais do gnosticismo estão postas com nitidez. As duas forças absolutas e eternas, uma natureza má chamada de Raça das Trevas, e outra boa, o próprio Deus, estão presentes no homem como partículas materiais da mesma natureza de suas fontes criadoras distintas entre si. Adão e Eva são frutos dessa gênese cósmica causada pelo Princípio das Trevas, filhos de entes demoníacos, criados para impedir o retorno das partículas de luzes à sua origem. Desse ponto, refere J. Kevin Coyle ${ }^{192}$, em acordo com Puech ${ }^{193}$, que o Deus da bondade passa a organizar o mundo para salvá-lo desta mistura cósmica. Constrói-se um mecanismo celestial em que a lua, o sol, e os planetas do zodíaco funcionariam como um tipo de armazém de partículas luminosas libertadas na terra a partir de rituais litúrgicos de seus adeptos.

191 As duas almas seriam um microcosmo, cópia em menor escala de toda cosmologia maniquéia. cf. De natura boni, 46

192 J. Kevin Coyle, Saint Augustine's Manichaean Legacy. Université Saint Paul, Otawa, Canada. 2002. Augustine Lecture. Augustinian Studies 34:1 (2003) p. 1-22. "To free the light from the matter with which it was now entangled, the God of goodness constructed a celestial mechanism, including the moon, the sun, and the planets that make up the zodiac. These were to serve as collector stations for the light eventually freed; they in turn would pass that light back to its true home. To forestall this, the evil principle caused a male and female demon to mate, and their union produced Adam and Eve. They were the world in miniature, since they contained in themselves both light (soul) and matter (body). The first humans, therefore, were not a creation of God, but the consequence of an evil initiative, their sole purpose being to keep as much light entrapped in the visible world as possible, chiefly by generating offspring."

${ }^{193}$ Ver nota anterior. 
Somente o divino conhecimento, gnosis revelado aos eleitos, poderia desprender as partículas de luzes aprisionadas nos corpos.

\title{
II,1,1 UM tRATAdo ENTRE A MI SÉRIA HumANA E A
} MI SERI CÓRDI A DI VI NA.

\begin{abstract}
Na verdade, já começava a querer parecer sábio, cheio do meu castigo, e não chorava, e inchava-me com a ciência, acima de toda a medida. Onde estava, pois, aquela caridade, que edifica a partir do alicerce da humildade, que é Jesus Cristo? Ou quando é que aqueles livros ma ensinariam? ${ }^{194}$
\end{abstract}

O prólogo de Sobre as Duas Almas anuncia tanto o tema de estudo quanto o modo e procedimento necessário para o desenvolvimento da obra. É importante notar que já no primeiro período do parágrafo, Agostinho dá a conhecer a situação da qual parte, pois, descreve-se como alguém já restituído, libertado dos laços dos maniqueus: "Pela ajuda da misericórdia de Deus os laços dos maniqueus foram quebrados e abandonados, e eu fui, enfim, restituído ao seio da igreja Católica. Agora, resta ao menos, considerar e chorar aquela minha miséria" ${ }^{195}$. Note-se a circularidade propositada entre passividade e atividade. A condição restituída de si é fato dado, passividade expressa pelo verbo restitutum (restituído) na voz passiva, acompanhado do agente auxiliador da "misericórdia de Deus". De outro lado, a atividade é marcada pela forma do verbo na infinitiva como segue: "E agora resta ao menos considerar e chorar aquela miséria minha". Considerar (considerare) e chorar ${ }^{196}$

\footnotetext{
${ }^{194}$ Cf. conf. VII, 20, 26: iam enim coeperam velle videri sapiens, plenus poena mea et non flebam, insuper autem inflabar scientia. ubi enim erat illa aedificans caritas a fundamento humilitatis, quod est Christus Iesus? aut quando illi libri me docerent cam?

195 “Opitulante Dei misericordia, disruptis et derelictis Manichaeorum laqueis, tandem Catholicae gremio restitutum libet considerare nunc saltem ac deplorare illam meam miseriam." duab. an. I,1

${ }^{196}$ Vertemos como chorar ao invés de lamentar para manter a força do da raiz plorare
} 
(deplorare) suas misérias de outrora, portanto, são as duas atividades mentais que dão sustentação à obra. $O$ par Dei misericordia e meam miseriam abrem e fecham, respectivamente, o primeiro parágrafo da obra e do prólogo. Tal binômio é de fato ponto norteador da obra, pois pensamos que tal conjunção inusitada não é casual, visto que indica uma dupla preocupação: 1) um modo pessoal confessional, em análise retrospectiva dos eventos históricos; e, 2) exploração da natureza metafísica da alma onde suas partes, superior e inferior, estão convocadas para a tarefa de filosofar e confessar, melhor dizendo, tarefa de confessar filosofando ou filosofar confessando. O jovem presbítero pensa que muito poderia ter sido feito para evitar tamanho erro que o assaltou das sementes da verdadeira religião plantadas nele desde a tenra idade, mas que, por razões, ou melhor, motivações que deve descobrir no decorrer da obra, não fizera outrora. Com isso, Agostinho parece desejar deslocar o interesse do seu leitor da mera curiosidade sobre a natureza da alma para um exercício espiritual confessional e interior, lugar de louvor e fruição de Deus. Perscrutar a si mesmo é ponto de partida para a possibilidade de conhecimento da verdade, enquanto que não pensar por si mesmo é recusar um projeto de autonomia individual e pretensão de que a razão discursiva (estratégia dos soberbos e loquazes cf. conf. $1 \mathrm{II}, \mathrm{vi}, 10^{197}$ ) sozinha pudesse, em recusando qualquer tipo de autoridade, levar a cabo a tarefa de purificação e ascensão a Deus. Isso posto, tal perscrutação interior revelará ao final o pecado (miséria), não como substância em si mesma, mas como ato e signo de uma condição de liberdade e fratura. A confissão será o terreno que dá ocasião e possibilidade para que as sementes da verdade sejam replantadas pela misericórdia divina. De fato, descobre-se que as sementes nunca foram extraídas, pois sempre

197 conf. III,6. 10. Itaque incidi in homines superbe delirantes, carnales nimis et loquaces, in quorum ore laquei diaboli 
estiveram ali mesmo, no ponto cego da profundeza interior. O que Ihe faltou foi a potência de perscrutação, uma vez que fora obstruída por outro tipo de visão inferior. De fato, o final do prólogo esclarece o seu início. Se na primeira frase Agostinho reconhece o papel restituidor da misericórdia de Deus (Opitulante Dei misericordia), necessária justamente porque o pecado a antecedeu (meam miseriam), será ao final do parágrafo, após o exercício considerativo e deplorativo da mente, que o Cristo é apresentado como o contraponto da miséria humana.

Em uma palavra, a questão da alma aqui não é um procedimento alheio a um tipo de autoanálise da alma ${ }^{198}$. Requer um esforço do pensamento e modelagem dos afetos. Os dois verbos considerare e deplorare como atividade da alma racional postos logo nas primeiras linhas do livro não nos parecem fortuitos; de fato, anunciam a conjunção de questões de procedimento filosófico e de natureza da alma. A investigação sobre as causas que outrora o assaltaram das sementes da fé é uma questão tanto do âmbito das capacidades dianoéticas quanto da contrição necessária ao ato confessional. Parece tratar-se de dois planos que se entrecruzam: pensamento e afeto. Não se trata tanto de prescindir um de outro, ou mesmo de sistematizar o procedimento da atividade mental - ao

198 Interioridade não é solipsismo. (ver conf. X,iii,3-4) Relacionar confissão e filosofia já indica que Agostinho está preocupado em ampliar os ecos da interioridade em outras interioridades (consciências). Cf. J. Pepin, Jean. «Le problème de la communication des consciences chez Plotin et saint Augustin», dans Revue de Métaphysique et de Morale 55, 1950, p. 128-148. Esse caminho interior de investigação deve ecoar na exterioridade comunicada. A exposição do pecado terá alguma utilidade para aquele que ouve com boa vontade e confiança, buscando ler nesse algo um signo ao seu próprio pecado, logo, a confissão deve ser entendida como um estilo literário que visa à educação e condução (docere et ducere). Em duab. an., a nosso ver, esse é o motivo pelo qual Agostinho ataca a filosofia maniqueia, ao mesmo tempo em que expõe a si mesmo como pecador. Dar, pois, publicidade aos descaminhos de outrora será útil ao leitor dessa filosofia confessional para encontrar a reta doutrina. Afastamo-nos, portanto, tanto da confusão de tomar a confissão tanto como exercício subjetivista, quanto de reduzila a mero recurso retórico cujo fim é somente ganhar a simpatia do ouvinte (opinião de Decret e Puech), como se no afã do convencimento Agostinho forjasse uma contrição confessional, a fim de convencer sua audiência. 
contrário, trata-se de identificar duas atividades igualmente imbricadas. O erro é mental, mas a alma do homem não se restringe a sua parte mais alta, a razão; e tão pouco o pecado é apresentado como um erro racional. De fato, o misterioso movimento da alma para o não-ser em afastamento do sumo ser revela que é necessário restituir o entendimento de um todo do complexo humano. A alma toda deve considerar o erro e chorar por "aquelas minhas misérias", pois a mente não apenas cometeu uma falta de cálculo racional como também se afastou da piedade, dos afetos do Deus criador; portanto, chora - não apenas porque infringiu uma regra moral, mas porque se dispersou de si enquanto distante do Ser. Ora, convocar o choro para acompanhar a atividade intelectual não nos parece um procedimento corriqueiro do sábio antigo ${ }^{199}$. Na verdade, revela que a condição de restituição da alma anunciada na primeira frase do livro dá condição para que a parte mais baixa da alma ${ }^{200}$, parte da alma mais perto do corpo e que faz o olho chorar, ganhe também dignidade de ação e participação nesse modo de fazer filosofia. Trata-se de uma dupla atividade da alma, regida pelas partes que lhe são próprias, e orientadas segundo cada natureza da coisa à qual dirige. A parte mais alta, para os inteligíveis; a outra para os corpos: ambas convidadas para a atividade do mesmo espírito que conhece a si confessando.

Dada a unidade da alma, a confissão é uma atividade singular e introspectiva, o que não the confere solipsismo confessional, pois diante do pecado a alma ganha o ofício de aprender por experiência, visto que confessar é, em outras palavras,

\footnotetext{
199 Possivelmente, Agostinho é original aqui. Ver Joseph Ratzinger, Le concept augustinienne de 'confessio'. In: Caron, Maxence, et al. Saint Augustin. Cerf, 2009. 200 A noção das partes da alma (superior e inferior) será ponto recorrente no tratado. Será exposto mais adiante como Agostinho poderia ter emprestado os termos de Plotino como resposta ao procedimento gnóstico de hipostasiamento da vida moral.
} 
tomar consciência "da distância entre inteligíveis e sensíveis", discernindo ${ }^{201}$, em cada ato de decisão, a distância hierárquica dos inteligíveis em relação às coisas no tempo e no espaço. O reconhecimento das próprias misérias (meam miseriam), como vimos no Genesis contra os maniqueus. $11,9,12$, é uma ciência proporcionada por um aprendizado da "experiência" - claro que tomamos o termo "experiência" com a devida distância da filosofia contemporânea, mas nosso autor não esconde que a experiência é a situação de onde a alma parte e "aprende" (discit). Posta em região intermediária, entre corpos e inteligíveis ${ }^{202}$, a alma aprende pela experiência para depor contra si mesma; e na medida em que, ao buscar sua natureza pelas evidências inteligíveis e imediatas, revelará ao final as misérias pessoais e a distância do semelhante. Em uma palavra, o pecado é meam miseriam.

O proêmio agostiniano tem o caráter de sintetizar o tratado, o que nos ajudará a interpretá-lo, ao passo que também adianta o conteúdo que agora se faz necessário demonstrar em seu movimento e estrutura.

\section{1,2 A ALMA COMO PRIMEIRA CONSI DERAÇÃo OU PRI MEIRO DESLOCAMENTO I NTERIOR (PRI US CONSI DERATUS)}

Primeiramente, é necessário estabelecer a importância da reflexão acerca da alma, a fim de realizar uma dupla recusa que: 1) que a alma divina seja da mesma substância de Deus; 2) que a alma má, sendo vivente, exista e provenha da fonte de vida, Deus.

\footnotetext{
${ }^{201}$ cf. Gn. c. man. II,9,12

202 Et cum hoc eius peccatum poena fuerit consecuta, experiendo discit quid intersit inter bonum quod deseruit, et malum in quod cecidit ( $E$ no momento deste pecado a pena que segue é que a alma deve aprender por experiência qual a diferença entre o bem que abandonou e o mal em que caiu). Gn. c. man. II,9,12.
} 
No debate público contra Fortunato, ocorrido poucos dias após o tratado de 392, Agostinho deixa claro a importância estratégica de iniciar o debate contra a doutrina maniqueia pela questão da alma:

A: Sobre estas almas que, segundo vocês, passam da morte à vida por intermédio de Cristo, qual é a causa delas terem precipitado na morte? F: Primeiro, negue se não há nada fora de Deus. A: Ao invés disso, se você não se importar, responda qual é a causa dessas almas terem sido lançadas à morte? F: Ao contrário, diga você primeiro, caso não se importe, se algo existe fora de Deus ou se tudo está em Deus? ${ }^{203}$

É possível perceber que os polemistas disputam pela pauta da discussão: por um lado, Agostinho possui uma ordem bem definida para combater a doutrina maniqueia, pois insiste que a investigação deve iniciar-se pela alma; por outro, Fortunato insiste em iniciar pela questão acerca da origem do mundo. Assim, as primeiras linhas do debate são marcadas por uma questão de ordem de pauta. Agostinho se esforça para iniciar a discussão pela psicologia; Fortunato, pela cosmogonia. De fato, veremos como o movimento de interiorização das naturezas é fundamental para a argumentação do hiponense, pois, somente após o reconhecimento de sua própria natureza, a alma pode avaliar por autoanálise o procedimento valorativo que constituíram as falácias e as falsas doutrinas por onde peregrinara.

${ }^{203}$ Contra Fortunatum I,4 AUGUSTINUS dixit: Has animas, quas de morte ad vitam per Christum venire fatemini, quae causa praecipitavit in mortem? FORTUNATUS dixit: Hinc iam dignare prosequi et contraire, si nihil praeter Deum. 5. AUGUSTINUS dixit: Imo tu dignare respondere id quod interrogaris, has animas quae causa morti dederit. FORTUNATUS dixit: Imo tu dignare dicere, utrum aliquid sit praeter Deum, an omnia in Deo sint. 
E. Gilson sintetiza bem a estratégia do hiponense: "Augustin n'a cesse de codifier les résultats de son expérience personelle"204. Assim, em Sobre as Duas Almas, a atividade de chorar pelas misérias pessoais é um caminho da interioridade e revela a exclusividade da postura imprópria da alma. Agostinho, então, passa a analisar os descaminhos de outrora em busca do entendimento das questões que o envolviam e o enlaçavam. Nosso autor faz uso da imagem das sementes plantadas na profundeza da alma:

Pois havia muitas coisas que eu devia ter feito para evitar que as sementes da verdadeiríssima religião, implantadas salvificamente (salubriter insita) em mim desde minha infância, tivessem tão facilmente e em tão poucos dias sido escavadas (efossa) e extraídas da minha alma pelo erro e fraude de homens falsos e falaciosos. ${ }^{205}$

A imagem visa traduzir o que aconteceu no mais profundo da alma (intus), pois ali, por causa de suas imposturas, as sementes foram extraídas, mas não pela força alheia a si mesma, pelo contrário por concessão interior. A mente não se fiou na piedade e na dependência do Deus, nem se dedicou com sobriedade e diligência, e, conseqüentemente, deixou que Ihe extraíssem da profundeza da alma as preciosas centelhas da verdade. Ainda que os maniqueus vindo de fora tenham lhe apresentado a falsa doutrina das duas almas, foi, ao final, ela mesma que se deixou levar. Tal assalto causou uma condição humana adoecida e aprisionada. O vocábulo latino "salubriter", que traduzimos como salvificamente ${ }^{206}$, é na verdade imagem de sanidade que se opõe, no caso, à ausência da sanidade, a doença. Com efeito, a alma foi assaltada e as sementes da verdade

\footnotetext{
${ }^{204}$ E. Gilson. Introduction à l'étude de saint Augustin, 1949, p. 31

205 duab. an. I,1. Multa enim erant, quae facere debui, ne tam facile ac diebus paucis, religionis verissimae semina mihi a pueritia salubriter insita, errore vel fraude falsorum fallaciumve hominum effossa ex animo pellerentur

206 Seguindo Jourjom (BA) e Roland Teske, mas Luis Pio (BAC) traduz como saudavelmente.
} 
Ihe foram extraídas como que escavadas (efossa) do interior do solo da alma. Extraída a capacidade de considerar as distinções necessárias quanto à hierarquia dos seres, sua natureza e força, Agostinho confessa ter se afastado por nove anos dos afetos do seu criador.

O engano que lhe subtraiu as sementes da verdade instauradas na alma parece ter uma origem primeira que pode ser considerada um erro fundador:

Pois, se primeiramente eu tivesse sobriamente e diligentemente considerado comigo mesmo, com mente piedosa e suplicante em Deus, aqueles dois gêneros de alma, aos quais os maniqueus atribuíram naturezas individuais e próprias, desejando que uma fosse da própria substância de Deus e a outra nem sequer estivesse relacionada a Deus como criador... ${ }^{207}$

É importante notar que Agostinho conduz toda a gravidade da questão maniquéia para o erro acerca da concepção de alma. O erro é ainda mais grave quando, por encadeamentos, acaba por determinar conclusões quanto à natureza da substância divina. Em mor. (388) Agostinho igualmente anunciava o programa de investigação necessário para o enfretamento da questão maniquéia: “Perguntemo-nos, pois, o que é superior ao homem? Encontra-se difícil sabê-lo se primeiramente não for considerado (prius considerato) a questão sobre o que é o homem em si mesmo"208. Se Agostinho busca pela verdade que transcende o próprio homem, a investigação deve iniciar pela consideração de si mesmo. De maneira

\footnotetext{
${ }^{207}$ duab. an. I,1 Nam primo animarum illa duo genera, quibus ita singulas naturas propriasque tribuerunt, ut alterum de ipsa Dei esse substantia, alterius vero Deum nec conditorem quidem velint accipi, si mecum sobrie diligenterque considerassem, mente in Deum supplici et pia...

208 cf. mor. 4. 6. Quaeramus igitur quid sit homine melius. Quod profecto invenire difficile est, nisi prius considerato atque discusso quid sit ipse homo
} 
análoga, a falsidade acerca do que é superior ao homem deve ser exposta segundo a análise de si mesmo.

O alcance da análise da falácia acerca dos "genêros de almas" dá testemunho do quanto a questão é importante a ponto de ser mesmo um pilar de todo sistema maniqueu. Note-se como, de início, a doutrina "d'aqueles dois gêneros de alma", segundo o texto supra citado, conduz à duas questões centrais: primeiro, sendo um dos 'gêneros' de alma da mesma substância de Deus, o próprio do humano e do divino estão assim confundidos e acabam por conduzir o homem ao estado de soberba por se pensar como o próprio Deus. Segundo, que exista uma alma que não seja criada por Deus, resolveria o problema da fonte do mal e do pecado, no entanto, como consequência inaceitável, seria necessário pressupor uma fonte coeterna ao próprio Deus, que fosse a origem de tal genêro de alma. Estas questões serão retomadas adiante; por hora, basta salientar a estratégia programática para o enfrentamento da gnose.

Desde o início, o estudo reflexivo (mecum) da natureza da alma é ponto de partida para a análise de erros que, se tivessem sido devidamente considerados, derruiria desde então toda a doutrina metafísica maniqueia ${ }^{209}$. Resta, pois, seguir a investigação sobre a possibilidade de conhecimento do que é alma, porque, afinal, almejase a exposição da falácia sobre o ser da alma.

\section{I,1,3 Entre A OPI NI Ão de doutí SSI MOS E A di aléticA}

Há duas observações introdutórias no tratado que nortearão nossa leitura: a primeira reconhece que o tema de alma e vida é questão disputada entre filósofos doutíssimos (et multum serenae

${ }^{209}$ cf. conf. V,14,24-25 
disputationis inter doctissimos indigens ${ }^{210}$ ); a outra diz que "de momento, a investigação confessional (conqueri) se cala acerca do corpo para lamentar sobre a alma" (Sed de corpore interim taceo: de anima conqueror ${ }^{211}$ ).

Sobre a opinião dos doutos, Agostinho recusa o debate técnico da filosofia e declara suspender a opinião para de um campo neutro, sem tomar partido de um ou outro (sine partium). Resta o exercício da razão que, como já foi dito, analisa os exemplos e contraexemplos pela dialética. É possível, então, excluir do tratado qualquer referência à metafísica platônica e se concentrar apenas nos movimentos argumentativos das definições? É preciso dizer que sim, e tentaremos dar atenção devida à força persuasiva dos argumentos. No entanto, visto que Agostinho se identifica com aquela escola cuja doutrina apreende os particulares pela participação à fonte, estamos igualmente justificados em nos esforçarmos a identificar o manejo (dialético) dos elementos neoplatônicos.

Em Confissões VII, Agostinho revela que a passagem do corporalismo maniqueu à interioridade de substância incorporal contou com a ajuda de alguns livros dos platônicos (libri platonicorum) $)^{212}$. Foi pela leitura desses livros que Agostinho adquiriu recurso especulativo para enfrentar o maniqueísmo e conduzir-se à interioridade:

Entrei no mais íntimo de mim, guiado por ti, e consegui, porque te fizeste meu auxílio. Entrei e vi com o olhar da minha alma, seja ele qual for, acima do mesmo olhar da minha alma, acima da minha mente, uma luz imutável, não esta vulgar e visível a toda a carne, nem era uma maior como que do mesmo

\footnotetext{
${ }^{210}$ duab. an. 11,2

${ }^{211}$ duab. an. 111,3

212 conf. VII, 9, 13.
} 
gênero, como se ela brilhasse muito e muito mais claramente e ocupasse tudo com a sua grandeza. ${ }^{213}$

É possível não transpor o testemunho das Confissões ao tratado de 392, em que pese a busca contínua de diferenciação da realidade espiritual à corporal? Cremos que não. I gualmente, Jolivet avalia o tratado quanto ao seu conteúdo e estratégia:

Esse é o tratado Sobre as Duas Almas: (...) será reconhecido pela força persuasiva com a qual santo Agostinho demonstra a existência e o primado do espiritual. ${ }^{214}$

Mas vale relembrar: nossa intenção não é realizar um trabalho genético e doxográfico. Interessa-nos o neoplatonismo apenas na medida em que esclarece o movimento dialético do pensamento do hiponense. Por outro lado, é preciso não menosprezar os antecedentes da tradição filosófica que por vezes aparecem no tratado. Parece ser esse o erro de Babcock:

Agostinho poderia agora argumentar sem usar a noção platônica do papel da mente na reta ordem do ser ou sem utilizar a hierarquia platônica de força e virtude na escala gradativa do ser. Ele poderia argumentar não apenas na linguagem de uma elite intelectual e cultural, mas também em uma linguagem de exemplo e contraexemplo. ${ }^{215}$

213 conf. VII, 10, 16: intravi in intima mea, duce te, et potui, quoniam factus es adiutor meus. intravi et vidi qualicumque óculo animae meae supra eundem oculum animae meae, supra mentem meam, lucem incommutabilem: non hanc vulgarem et conspicuam omni carni, nee quase ex eodem genere grandior erat, tamquam si ista multo multoque clarius claresceret totumque occuparet magnitudine.

214 "Tel este le traite Des deux âmes. (....) on sera saisi par la force persuaive avec laquelle saint Augustin démontre I' existence et la primauté du spirituel » Jolivet In: BA 17, p. 48

215 Babcock, William. Augustine on Sin and Moral Agency, In: The Journal of Religious Ethics, Vol. 16, No. 1 (Spring, 1988), pp. 28-55.

Sobre a presença da filosofia no tratado, Babcock afirma: "The shape of this new position can be discerned, at least in outline form, in Augustine's treatise On Two Souls Against the Manichees, written shortly after his ordination to the priesthood in Hippo Regius in 391 and visibly an attempt, it seems to me, to carry the 
Agostinho, de fato, não parece ter como público uma "elite cultural" formada na doutrina dos doutíssimos filósofos. Tão pouco dirige-se aos neófitos cristãos que, segundo Puech, teriam sido facilmente manipulados pelas distorções más intencionadas do novo líder da igreja de Cartago. É mais provável que o tratado tenha em vista os próprios maniqueus. ${ }^{216}$ No fechamento do tratado, Agostinho indica que os destinatários são aqueles que, junto com ele, aprendiam o dogma da seita, ou seja, seus amigos maniqueus de juventude:

\begin{abstract}
Atentai para essas questões, queridos: conheço bem o engenho de vocês. Se concedem a mim a mente e razão que qualquer homem tem, essas questões serão muito mais certas de aquelas que nós pensávamos estar aprendendo [naquela seita]..$^{217}$
\end{abstract}

Nada há de manipulável ou ingênuo nesses maniqueus, ao contrário, Agostinho com frequência ressalta o engenho dos amigos de juventude, cuja capacidade discursivo-dialética tanto tinha atraído o jovem retor sedento por sabedoria e glória. Então, como convencêlos no terreno da dialética, que tanto estimam? Certamente, não por argumentos ingênuos.

Em outro sentido, F. Decret defende que Agostinho teria conhecido o dogma das duas almas, mas intencionalmente distorcido

argument against Manichaeanism beyond the realm of philosophic discourse and into the less lettered arena of the Christian congregation (see duab. an. 10.13)". grifo nosso.

Há duas declarações problemáticas aqui: a primeira refere que duab. an., diferentemente do lib. arb., 'está além da realidade da discussão filosófica'; a segunda, destina o texto aos 'iletrados' cristãos das congregações eclesiais. Que o tratado não se destine às disputas filosóficas parece bem claro e anunciado pelo bispo de Cartago, mas que o destinatário do tratado seja um público iletrado das congregações eclesiais, já não há base textual.

${ }^{216}$ Cf. Roland Teske, Augustine, Saint, The Manichean Debate., 2006, p. 111.

217 duab. an. XV,24. Attendite ista, quaeso, carissimi: vestra ingenia bene novi. Si mihi nunc vos qualiscumque hominis mentem rationemque conceditis, multo certiora sunt, quam quae ibi vel videbamur discere. 
seu conteúdo, que se torna incoerente somente quando deslocado para outro campo teórico:

\begin{abstract}
Note-se que, sob aparências rigorosamente lógicas, a alternativa que Agostinho sustenta a fim de provar as contradições internas da posição maniqueia denota na realidade uma argumentação enganosa, apoiando sobre uma petição de princípio. (..) Este argumento pode sem dúvida ter tido valor aos olhos dos não maniqueus, mas, sobre o terreno da polêmica propriamente dita, ele fecha-se em suas próprias definições e pretende obrigar o adversário a admiti-las como base. ${ }^{218}$
\end{abstract}

Decret faz um esforço admirável de reconstruir a polêmica das duas almas, que, segundo ele, pode ser reconstituída se considerarmos a suposta má vontade do polemista adversário à gnose. Evidentemente, parte de uma leitura de suspeita que não nos cabe aqui refutar. Mas a crítica do estudioso da gnose corrobora nossa leitura nos seguintes aspectos: 1) Agostinho, de fato, segue um plano argumentativo "rigorosamente lógico"; 2) Opera pela razão com distinções e definições (dialética); 3) Insere conceitos estrangeiros à doutrina maniqueia (metafísica neoplatônica) .

Por tais características, podemos entender melhor a declarada estratégia de "se calar acerca dos corpos para lamentar acerca da alma" (Sed de corpore interim taceo, de anima conqueror $^{219}$ ). Com efeito, "calar-se acerca dos corpos" é um procedimento da dialética, conforme a definição da disciplina na Doutrina Cristã: a dialética discorre sobre "os conhecimentos relativos

\footnotetext{
218 "On remarquera là que, sous des apparences rigourreusement logiques, l'alternative que pose Augustin afin de prouver les contradictions internes de la position manichéene dénote em réalite une arrgumentationspécieuse reposando ser une pétidtion de principe. ... [sobre pecado e penitência] Ce raisonnnement peut sans doute avoir valeur aux yeux de non Manicheénes, mais, ser le terrain de la polémique propremente dite, c'est s'enfermer ser ses prpores 'definitions'et prétendre obliger l'adversaire à les admettre comme base de départ'" Decret, François. Aspects Du Manichéisme Dans L'Afrique Romaine, 1970, p. 337-8

${ }^{219}$ Cf. duab. an. III,3
} 
não aos sentidos do corpo, mas à razão da alma, onde domina a disciplina do raciocínio disputativo e da matemática (disputationis et numeri)"220. Em Sobre a Ordem 11,13,38, Agostinho classifica a dialética como a "disciplina das disciplinas" responsável pelas "definições, divisões e sínteses" dos enunciados que se formam a partir dos vocábulos que a gramática associou às coisas ${ }^{221}$. Não é uma disciplina como as outras; ela, na verdade, antecede e possibilita as demais. Assim, a dialética opera com definições e distinções que fornecem a "certeza do saber", pois nela "a razão se mostra o que ela mesma é" e assim "defende-se das falsidades". Os Solilóquios também testemunham a dialética como a disciplina das disciplinas, pela qual se operam as distinções e definições do raciocínio independentemente dos $\operatorname{corpos}^{222}$.

Em Sobre as Duas Almas a "razão busca a certeza do saber mostrando o que ela mesma é"; associa-se, sobretudo, à verdade imperecível, à verdade verdadeira (vera veritas ${ }^{223}$ ), que não morre e está na alma:

De momento, me calo acerca do corpo; passo a investigar confessionalmente (conqueror) a alma: seu movimento espontâneo e vital, sua atividade, sua vida e sua imortalidade. Confesso, enfim, que, pela minha

\footnotetext{
220 Doctr chr. 11,31,48 Restant ea quae non ad corporis sensus, sed ad rationem animi pertinent, ubi disciplina regnat disputationis et numeri.

${ }^{221}$ De Ordine $11,12,35$

222 Mammì, L. Agostinho e as Artes: “Em Solilóquios II, xi, 21, a questão é colocada explicitamente: se o que caracteriza uma disciplina é o fato dela ser baseada num sistema de definições, distinções e raciocínio (o esquema tradicional dos manuais de artes), a dialética, que ensina a definir, distinguir, é superintendente a todos as outras disciplinas. Por outro lado, por ser ela mesma baseada no mesmo sistema, é ela mesma uma disciplina; mas é uma disciplina cuja verdade depende dela mesma (per ipsam disciplina vera est)", p.21.

${ }^{223}$ cf. sol. II,11,21.
} 
miséria, tenha crido que algo tivesse esses atributos sem a bondade de Deus. ${ }^{224}$

O verbo "conqueri", que literalmente pode ser traduzido por "lamentar", é evidentemente mais do que lamento, no sentido de uma mera emoção. O objeto do lamento é a teoria acerca da alma: "seu movimento espontâneo e vital, sua atividade, sua vida e sua imortalidade". Assim, lamentar esses atributos da alma é investigar a verdade sobre a alma, de modo que nos permitamos uma tradução mais livre de "conqueror" por "investigação confessional".

O que se investiga não é a ação do corpo, mas o movimento da alma que se enganou. $O$ tratado tem o interesse principal de exibir a razão no momento do engano: "[na dialética] a razão ela mesma exibe-se e revela sua própria natureza, seus desejos e suas potências" (Solilóquios $11,13,38$ ). Por isso que se pode dizer que 0 principal objeto de análise não é bem a falsa doutrina, mas o pensamento do ex-maniqueu, que não reconheceu a doutrina maniqueia como simulacro do verdadeiro.

A estratégia não poderá ser outra senão "exibir" a razão que fez a passagem enganadora dos sensíveis aos inteligíveis. Ou dito de outro modo, Agostinho deve confessar o momento em que sua alma erra na tarefa de "aprender por experiência a diferença entre sensíveis e inteligíveis"225. Com efeito, exibe-se a alma no seu pior momento, no engano. Por aí, entende-se porque Agostinho avisa logo nas primeiras linhas do tratado que não se tratava de falar da beleza dos corpos, nem da participação do belo.

\footnotetext{
${ }^{224}$ duab. an. III,3 Sed de corpore interim taceo: de anima conqueror, de spontaneo et vivido motu, de actu, de vita, de immortalitate: denique conqueror, quod aliquam rem ista omnia sine Dei bonitate habere posse miserrimus credidi -

${ }^{225}$ Gn. c. man. II, 9,12 . supra cit.
} 
Em Sobre as Duas Almas, os elementos mobilizados em "exemplos e contraexemplos" são indícios do pensamento em movimento, da dialética em operação, de onde Jolivet ressalta o gênio da "força persuasiva" do bispo, ao demonstrar a "existência e primado do espiritual"226. Acrescentamos, ainda, que tal demonstração só foi possível devido à mobilização dos dados internalizados das representações sensíveis em comparação aos inteligíveis, que por sua vez, sabe-se pelo testemunho das Confissões, sucedeu a "ajuda daqueles livros platônicos".

\section{II,2 VIDA E ALMA}

\section{I ,2,1 VI DA E DERI VAÇÃo}

O alcance da análise da vida em relação à alma não é questão menor. Almeja-se encontrar a "fonte e princípio de vida" ( vitae fontem principiumque ${ }^{227}$ ), ao passo que se estabelece de início um princípio único de derivação, isto é, a vida como tal não pode ter múltiplas procedências. Agostinho lamenta que não tivera esse princípio de partida: "se naquela época tivesse satisfatoriamente aparecido a mim que não há vida que não pertença, e pelo fato mesmo que é vida e à medida que é de fato vida (ominino vita est) ${ }^{228}$, à suprema fonte e princípio de vida"229. E logo em seguida declara que a vida dos particulares deriva por participação da Vida: "sobre a própria vida e sobre a participação da vida" (de ipsa vita et de participatione vitae) 230231 .

\footnotetext{
${ }^{226}$ cf. Jolivet In: BA 17, p. 48.

227 cf. duab. an. 1,1

228 ou "vida em geral/absoluto", mas o contexto indica o sentido enfático. É também a opção de Pio Luis: "precisamente porque é vida" (BAC).

${ }^{229}$ duab. an. I,1. fortasse mihi satagenti apparuisset, nullam esse qualemlibet vitam, quae non eo ipso quo vita est, et in quantum omnino vita est, ad summum vitae fontem principiumque pertineat.

${ }^{230}$ cf. duab. an. 11,2 .
} 
Esse vocabulário é reconhecidamente platônico e Agostinho dá o endereço da discussão (disputationis inter doctissimos indigens).

Por esta razão, essas almas, que os maniqueus chamam de más, ou carecem de vida ou vivem. Se carecem de vida, não são almas, nem podem querer e não querer, apetecer ou fugir. Se elas vivem, para poder ser almas e agir tal qual eles opinam, não poderiam de modo algum viver senão pela vida ${ }^{232}$.

O que importa enfatizar logo no início do tratado é o esforço argumentativo de associar vida e alma como elementos imbricados, por onde é possível pensar a derivação da vida na exata medida do compartilhamento entre a fonte de toda a vida em particular:

Naquele tempo meu pensamento era incapaz de portar e sustentar a questão sobre a vida em si mesma e sobre a participação da vida. Porque esta é certamente uma importante questão e que requer muita discussão atenciosa entre pessoas doutíssimas. ${ }^{233}$

Mas dizer que a vida da alma deriva da Vida, que é fonte da vida em geral, não basta, porque a gnose também afirma que alma boa deriva da Vida que não pertence ao mundo, mas está no mundo pela tragédia da queda. Segundo H. Jonas: “Ao nome da Vida grande, primeira, estrangeira, vinda do mundo de luzes, a sublime que permanece acima de todas as obras: é o início clássico das composições mandeístas; o 'estrangeiro' é o atributo constante do

\footnotetext{
${ }^{231}$ Sobre a relação entre alma e vida E. Gilson interpreta Agostinho com expressões que o leitor de filosofia moderna não deixará de familiarizar-se: "a alma apreendese como substância irredutível à extensão... Mas a alma, ao mesmo tempo que apreende-se como vida fonte de vida [do corpo], a alma se aprende como inseparável certeza que tem de si mesma" E. Gilson, Introdução ao Estudo de Santo Agostinho. 2007, p. 117.

232 duab. an.l,1 Quapropter illas animas, quae a Manichaeis vocantur malae, aut carere vita, et animas non esse, neque quidquam velle seu nolle, appetere vel fugere; aut si viverent, ut et animae esse possent, et aliquid tale agere, quale illi opinantur, nullo modo eas nisi vita vivere.

233 cf duab an.Il.2 Quod si tempore illo quaestionem de ipsa vita et de participatione vitae mea cogitatio ferre ac sustinere non posset; quae profecto magna est, et multum serenae disputationis inter doctissimos indigens.
} 
nome 'vida', porque a vida, por essência, é estrangeira a este mundo"234. Então, qual a natureza da vida? Até aqui, sabe-se que o próprio da alma é a vida e que não se trata de um atributo contingente, pois, retirada da vida a alma não pode sequer ser algo. Resta investigar a natureza da vida/alma.

\section{II,2,2 ARgUMENTO deCI SI VO: SUBSTÂNCI A I NCORPORAL}

Em Confissões V, Agostinho desenvolve a noção de substância espiritual como pedra-de-toque de toda a falsidade maniqueia:

Foi então que comecei a empenhar todas as forças do espírito na busca de um argumento decisivo para demonstrar a falsidade dos maniqueus: se me fosse possível conceber uma substancia espiritual, todos os obstáculos teriam sido superados e afastados do meu espírito. Mas não podia. ${ }^{235}$

Para afastar da alma a falsidade, basta "entender o que a coisa é". Ou nas palavras de Bermon: entender "infalibilidade das representações inteligíveis" ${ }^{236}$ :

Quem entende outra coisa diferente do que a coisa é, engana-se; e todo aquele que se engana não entende o que se engana. Quem, pois, entente outra coisa do que

\footnotetext{
234 "Au nom de la Vie grande, première, étrangère, venue du monde des lumières, la sublime qui se tien au-dessus de toutes ouvres": c'est le début classique des compositions mandéenes; 'étranger' est l'attirbut consta du nom 'vie', car la vie, par essence, est étrangere à ce monde". Jonas, Hans. La religion gnostique. Le message du Dieu Étranger et les débuts du christianisme. 1978, p. 72.

${ }^{235}$ conf. V, 14,25 Tum vero fortiter intendi animum, si quo modo possem certis aliquibus documentis (argumento decisivo) Manichaeos convincere falsitatis. Quod si possem spiritalem substantiam cogitare, statim machinamenta illa omnia solverentur et abicerentur ex animo meo: sed non poteram. Tradução Maria L. Amarante.

${ }^{236}$ Bermon, Emmanuel. La Signification Et L'enseignement: Texte Latin, Traduction Française Et Commentaire Du De Magistro De Saint Augustin. Paris: Librairie philosophique J. Vrin, 2007. p. 469.
} 
a coisa é, não entende essa coisa. Portanto, não se pode entender uma coisa senão como ela é, do mesmo modo que não é entender nada quando se entende o que não é. ${ }^{237}$

O verbo "entender" (intellegere) é preciso e remete a parte intelectiva da alma, que é responsável por "compreender" substâncias inteligíveis. Então, para pensar a indubitável natureza da alma e da vida, deve-se pensar se, primeiramente, é possível que alma entenda a si mesma e, consecutivamente, questionar se seria possível conhecer a alma má.

Insere-se aqui o argumento conhecido como cogito agostiniano $^{238}$, que, no contexto da polêmica maniqueia, visa estabelecer a substância incorporal da alma:

Pois, se eu tivesse interrogado a mim mesmo e tivesse invocado a Deus sobre o que é viver, não poderia ter respondido, ainda que escape aos sentidos corporais e seja absolutamente incorporal? ${ }^{239}$

Nada é trivial aqui. Será útil explorar o caráter eclético do cogito agostiniano ${ }^{240}$.

\footnotetext{
${ }^{237}$ div. qu 32. Quisquis ullam rem aliter quam ea res est intellegit, fallitur; et omnis qui fallitur, id in quo fallitur non intellegit. Quisquis igitur ullam rem aliter quam est intellegit, non eam intellegit. Non ergo potest quidquam intellegi nisi ut est. Nos autem aliquid ita ut est intellegimus, velut hoc ipsum nihil intellegi, quod non ita ut est intellegitur. Consultar também Gen. ad lit XII,25,52 cf. Bermon. La signification..., p. 469.

238 cf. Charles Taylor. Sources of the self: : the making of the modern identity, 1989:: "Augustine was the inventor of the argument we know as the cogito, because Augustine was the first to make the first-person standpoint fundamental to our search for truth" p. 113.

${ }^{239}$ duab. II,2 Num enim quid sit vivere, quamque secretum ab omni corporis sensu, quamque omnino incorporeum, si me ipsum invocato Deo interrogarem, respondere non possim?

${ }^{240}$ A expressão "cogito" guarda tanto aproximações quanto profundas distâncias do cogito cartesiano. Sobre o tema, consulte-se Bermon, Emmanuel. Le Cogito Dans La Pensée De Saint Augustin. Paris: Vrin, 2001. ; Wayne Hankey, Between and Beyond Augustine and Descartes: More than a Source of the Self; Augustinian Studies 32: I 2001; Moacyr Novaes, Eternidade, interioridade sem sujeito. Analítica vol 9 (1). 2005 ; Marion, Jean-Luc. Au Lieu De Soi: L'approche De Saint Augustin,
} 
2008. pp.89-148, 225-229; Blondel, Maurice. Le quinzième centenaire de la mort de saint Augustin. Revue de métaphysique et de morale ano: 1930 vol.: 37 .

Etienne Gilson, Le rôle de lá penseé médiévale dans la formation du système cartésien, Paris 1930, cap. 'Le cogito e la tradition augutinienne', é especialmente esclarecedor ao comparar Descartes e Agostinho pelas passagens da Il e Méditation, t. IX com o De Trinitate, X. Gilson demonstra a estratégia comum da imediação do puro pensamento que pensa a si em contraste com a necessária mediação discursiva do pensamento quanto aos corpos. Assim, não compartilha da opinião que Agostinho estivesse se 'aventurando' (referência a Pascal) quando fez uso do argumento do cogito: : "Et nous sommes également loin d'avoir affaire à un 'mot dit par saint Augustin à l'aventure, puisque, comme celui de Descartes, tout son raisonnement s'appuie sur l'opposition entre la conscience immédiate que la pensée a d'être pensée et l'absence de toute conscience immédiate qu'elle ait d'être un corps ou rien de ce qui appartient au corps". p.198 A fim de afastar qualquer casualidade do cogito no pensamento de Agostinho, Gilson elenca cinco retomadas do argumento no pensamento do bispo, a fim de recusar a opinião de Pascal de que o argumento não tivesse peso conceitual importante: "A cinq reprises, saint Augustin est revenu sur son argument, le perfectionnant et le complétant sans cesse: ce n'est pas l'attitude d'un homme qui n'attache pas d'importance à ce qu'il dit" p. 194. Seguem-se as referências que Gilson reporta: 1) Solilóquios, 2) Contra Acadêmicos, 3) Cidade de Deus, 4) Trindade, 5) Livre Arbítrio. Vale dizer que não encontramos em nossa pesquisa bibliográfica uma análise que reputasse o cogito em duab. an. como conceito importante no quadro geral da argumentação do livro; como de fato o consideramos.

Nossa posição quanto ao cogito partilha da mesma esteira de Gilson, isto é, ambos pensadores, Agostinho e Descartes, tomam o cogito com inferências argumentativa e estruturas metafísicas bastante semelhantes; apesar da notória distância entre eles; principalmente no tocante ao projeto epistêmico de fundação matemática para física mecanista (p. 194). No entanto, como refere Gilson, ambos exploram o caráter intuitivo e imediato do argumento, conferindo irredutibilidade da existência ao pensamento que se pensa imediatamente, sem que para isso se dependa dos sensíveis. O que parece mesmo marcar a distância não é, pois, a via metafísica que compartilham, mas o alcance que cada um conferiu ao cogito em seu pensamento: o ponto de chegada certamente não será o mesmo em ambos os filósofos, visto que Descartes insere o cogito como método que visa generalizar e unificar as ciências como explicação matemática da totalidade do real. Contudo, Gilson parece delimitar muito bem as semelhanças metafísicas dos pensadores. O ilustre historiador chega mesmo a dizer: «II n'y a guère que deux grandes voies ouvertes à la spéculation métaphysique: celle de Platon et celle d'Aristotle (...) En abandonnant l'empirisme thomiste, il se fermait la métaphysique thomiste; pourtant, il lui fallait une métaphysique, et même, ainsi qu'on l'a vu, une métaphysique de la distinction de l'âme et du corps ; celle de saint Augustin était là, toute prête à l'accueillir ». p.199 seq. Assim, Gilson identifica que se abria para Descartes apenas dois caminhos de especulação metafísica: uma, a que ele chama de "metafísica do inteligível" (procedimento a priori, passagem das ideias às coisas); e outra, a "metafísica do concreto" (procedimento a posteriori, passagem das coisas aos conceitos). No início do sec. XVII, a escolha pela primeira levaria inevitalmente ao encontro com o bispo de hipona: «Et puisqu'il a décidé d'aller de la pensée a la chose, il ne peut pas définir sa pensée autrement que par le contenu qu'elle exhibe à l'intuition qui l'appréhende ». p.200;

Recentemente, seguindo E. Gilson, Brachtendorf, The Reception of Augustine in Modern Philosophy. In: A Companion to Augustine, 2012, reconhece tanto as semelhanças quanto as distâncias do cogito em ambos pensadores. Apoiado em Trin. X refere que Agostinho e Descartes partem da 'compreensão de si' sem que 


\section{AnTECEDENTE 1: Trí ADE SER-VI DA-I NTELECTO}

A tríade ser-vida-intelecção, cujos elementos constituem a base do conhecimento imediato de si, faz parte de uma tradição filosófica que teria chegado a Agostinho por Plotino. Hadot indica que Plotino, por sua vez, teria recebido a tríade de duas tradições. A primeira remontaria ao Sofista, 248e, em que Platão faz uso da tríade para combater as teorias imobilistas do puro ser, "ser em si" (einai): "sendo conhecido pelo conhecimento, na medida em que for conhecido se movimentará em virtude de sua própria passividade, o que não poderia dar-se, conforme dissemos, com o que está em repouso"241. A fim de defender a tese da "vitalidade do ser contra o idealismo"242, Platão reconhece que, para ser conhecido, o ser deve partir do movimento, associando assim conhecimento e ser em movimento, vivo portanto. O embate de Plotino é de outra ordem. É contra o materialismo estoico que Plotino relaciona ser e vida, conforme a formulação na Enéadas V, 4[7],2: “a vida não é um cadáver, porque há vida e inteligência". Em outra passagem, Plotino associa ser, vida e intelecção com o caráter substancial incorporal do ente perfeito: “Uma vez que o ente é perfeitamente, não precisa de nada para conservar-se e para ser, mas ele é a causa de que as demais coisas, as que parecem ser, pareçam ser. Com efeito, se tais coisas são ditas corretamente, é necessário que o ente seja em vida e

para tal se dependa das representações sensíveis, logo uma intuição do espírito. Cite-se: "Both men believe that, from the self-certainty of the thinking I, its immateriality can be proved. In each case the basic notion is that, while the mind comprehends itself immediately through itself alone (...). When the mind comprehends itself directly through itself, they claim, its knowledge is indubitable". Semelhantemente ao que pretendemos demonstrar em duab. an: chamamos de cogito a certeza imediata que a alma tem de si mesma quando se sabe viva,,, por parte do intelecto que compreende a vida sem passar pelos sentidos dos corpos.

${ }^{241}$ Platão, O Sofista 248e. Tradução de Carlos Alberto Nunes, UFB 1980.

242 Hadot, P. Le Sources de Plotin, 1957, p. 108. 
em vida perfeita" 243 . A perfectibilidade do ente incorporal garante sua impassibilidade diante dos corpos. O corpo, então, não afeta o ente incorporal, mas é ele mesmo efeito do ente de vida perfeita. Stephen Mackenna esclarece, ao comentar o tratado 26, Sobre a impassibilidade dos incorporais, que é importante para Plotino, no interior da discussão da apatheia estóica, "que a alma deva ser vista como totalmente livre de ser afetada ou modificada pelas influências corporais" 244 . Com efeito, a tríade do Sofista serve aqui para concluir que "o ser não é nem corpo, nem substrato de corpo"245.

Aristóteles é outra tradição que chegaria a Plotino. Na Metafísica 1072b 27, a interpretação do Sofista 248e é acrescida da vida que já não é identificada ao ser, mas à intelecção: “a vida seria como aquela que dorme (se não pensasse)"246. Conclui Hadot acerca das duas tradições da tríade: "quando Plotino se inspirava no Sofista, a vida aparecia como o ato do ser. Agora, sob a influência de Aristóteles, ela identifica-se à intelecção, ela torna-se o ato da inteligência" ${ }^{247}$. Com efeito, a visada plotiniana da vida sofre dupla influência que comporá a tríade: "se o ser é uma vida, como quer Platão, o pensamento é também uma vida, como quer Aristóteles"248. Ao tentar identificar na primeira intelecção tanto o ser de substância incorporal quanto o pensamento funde-se em unidade "ser-vidaintelecção" que, por sua vez, será tomada como elementos constituintes da questão do conhecimento de si, como veremos, em Enéadas V,3[49], em que conhecer é conhecer a si como "primeira

\footnotetext{
243 Plotino. Enéadas III,6[26],10-32.

244 "that the soul should be seen as entirely free from being affected or modified by external (bodily) influences.". Stephen Mackenna, The Enneads. 3d ed. London: Faber and Faber, 1962, localização virtual 5777:

245 Plotino. Enéadas III,6[26],32.

${ }^{246}$ Aristótoles, Metáfisica 1072b 27; apud Hadot. idem. P. 112.

${ }^{247}$ Hadot, idem, p. 113.

${ }^{248}$ Hadot, idem, p. 113.
} 
substância que está em ato"249; um “inteligível animado", vivo $\left(z o e^{250}\right)$, que se conhece na imediata identidade entre o pensamento, o ato do pensamento e alma intelectiva que pensa a si mesma.

\section{ANTECEDENTE 2: RepREsentAÇÃo CATALÉPTI CA UNI VERSAL}

É preciso fazer a passagem pelos modos possíveis de captação das coisas, antes mesmo de encontrar a primazia da evidência intelectual que se apresenta indubitavelmente ao conhecimento como intuição do pensamento. Dada a situação mediana da alma, no meio das coisas, há dois modos de internalização das naturezas. A primeira constatação é: "tudo de que se diz ter ciência (scire) e conhecer (nosse) nós o compreendemos (comprehendere) ou pelos sentidos do corpo ou pela inteligência"251. Importa reconhecer que a distinção entre scire e nosse não é casual. Há um sentido preciso pelo qual Agostinho refere aos modos de recolhimento e internalização das naturezas na alma. Consulte-se o trecho da Trindade:

Agora, sobre aquela parte da razão concernente à ciência (scientia), isto é, ao conhecimento das coisas temporais e mutáveis, necessárias para o desempenho das atividades dessa vida... Sem dúvida, o sentido do corpo sente as coisas corporais, enquanto que a razão concernente à sabedoria intelige verdadeiramente as coisas espirituais e imutáveis. ${ }^{252}$.

\footnotetext{
249 Plotino, Enéadas V,3[49],5, 33-37.

250 Há uma distinção entre bio e zoe. Puech, Entretiens Hardt V, 1960, p. 154.: "bios é uma vida da existência, histórica e contingente, ao passo que zoe exprime 'a vida realizada e estabilizada em sua plenitude, o desabrochar da liberdade e totalidade do ente.'" apud Baracat, p. 151.

${ }^{251}$ cf duab. an. II,2 omne quod scire et nosse dicimur, aut sensu corporis, aut intelligentia nos habere comprehensum.

252 Trin. 12. 17. Nunc de illa parte rationis ad quam pertinet scientia, id est, cognitio rerum temporalium atque mutabilium navandis vitae huius actionibus necessaria,
} 
A primeira via de internalização refere-se à percepção dos sensíveis pelo termo "ter ciência" (scire), enquanto que a segunda via faz a compreensão do inteligível para "conhecer" (nosse) verdades imutáveis e espirituais. Desde já, evidencia-se a posição fronteiriça da alma entre sensíveis e inteligíveis, visto que é própria da capacidade anímica a dupla percepção de substâncias que podem ser tanto mutáveis quanto imutáveis.

A via da ciência maneja os dados captados por intermédio dos sentidos do corpo, notadamente a visão, audição, odor, paladar e toque. Mas o corpo, pelo fato mesmo que é mais mutável, é inferior à inteligência, pois o que é captado pela inteligência é superior em imutabilidade; justamente porque a parte mais excelente da alma é chamada mente e inteligência, e disso não se pode duvidar. Assim, o critério valorativo das coisas internalizadas segue a própria via de captação. Se "compreendidas" pela inteligência, tem mais imutabilidade do que aquelas coisas "recebidas" pelos sentidos.

Note-se que Agostinho não desqualifica a veracidade da ciência captada pelos sentidos do corpo (scire), mas percebe a diferença qualitativa entre elas. A ciência (scientia) por via sensível não poderá dar por si mesma critério de verdade de mesma qualidade que a via inteligível dará ${ }^{253}$. A crítica das naturezas corporais deve ser entendida no seu contexto. Mais do que

susceptam considerationem, quantum Dominus adiuvat peragamus.(...) Sensu quippe corporis corporalia sentiuntur; aeterna vero et incommutabilia spiritalia ratione sapientiae intelleguntur.

${ }^{253}$ cf. Gn. litt. XII,11,21.. Pepin defende a identificação intellegibilis e intellectual em Agostinho por influência de Plotino e Porfírio a partir de números textos do gn. litt postos em paralelo com o Enéadas 5,3. Consultar PEPIN, J. Une curieuse déclaration idéaliste du De Genesi ad Litteram de saint Augustin, et ses origines plotiniennes: remarques sur une citation paulinienne des Confessions de saint Augustin. Paris: In: Revue de d'histoire et de philosophie religieuses, vol. 34, 1954. Sobre a infabilidade da visão intelecutal diante da visão corporal, consultar nota de Agaesse e Solignac, Le trois genres de visions In: Augustin. Ouvres de Saint Augustin. La genèse au sens littéral. De genesi ad litteram.p.578. 
desqualificar o sensível, pretende-se, na interlocução contra a gnose corporalista, evidenciar a natureza da alma como distinta das coisas extensas. A alma é, assim, posta em região intermediária na ordem de naturezas e tem a incrível capacidade de, no plano ético, movimentar-se em direção a um ou a outro. Deve assim "julgar" os valores de natureza das coisas recebidas, ordenando cada substância segundo sua propriedade ("peso e medida"). Desse modo, ratifica-se - papel da alma que, sendo mutável no tempo, é a única das naturezas criadas capaz de fazer um recolhimento tanto de sensíveis quanto inteligíveis ${ }^{254}$.

A percepção desses dados está, desde o início, relacionada a uma potência moral e ativa. O homem deve receber, julgar e valorar movimentando-se em direção a elas. Tal atividade é a condição de partida estabelecida na criação ${ }^{255}$. Desse plano de absoluta liberdade, o homem tem em suas mãos a possibilidade de apropriação de si, ou de alienar-se por dispersão. De fato, ontologia e ética aparecem como campos imbricados na filosofia do hiponense. Não é fortuito, pois, que o filósofo narre suas errâncias com espanto e arrependimento; como peregrino em terras gnósticas, por onde, durante nove anos, perambulou ${ }^{256}$ como aprendiz e professor. Em suas palavras: "seduzido e sedutor, enganado e enganador (falsi atque fallentes)"257. A falácia maniqueia que traduziu o não ser em ser, elevando a imagem (phantasmata) à natureza, foi mais que engano da razão, foi uma sedução do espírito.

\footnotetext{
${ }^{254}$ cf. epist. 140.

255 cf. Gn. c. man. $11,9,12$

256 cf. conf. I, 1,1 "aufero".

257 cf. conf. IV 1 , 1 Per idem tempus annorum novem, ab undevicesimo anno aetatis meae usque ad duodetricesimum, seducebamur et seducebamus falsi atque fallentes in variis cupiditatibus et palam per doctrinas, quas liberales vocant, occulte autem falso nomine religionis.
} 
Visitemos brevemente o contexto filosófico da relação entre verdade ou falsidade com o termo comprehensum, a fim de verificar como Agostinho se apropria da tradição para combater a falácia maniqueia.

\section{COMPRENHENSUM. I NTERNALI ZAÇÃO DE NATUREZAS}

O termo é reconhecidamente proveniente da filosofia estoica, que chega a Agostinho, possivelmente, por meio de Cícero: “[Zenão] não atribuía credibilidade a todas as impressões, mas apenas àquelas que trouxessem consigo a manifestação própria dos objetos percebidos; essa impressão, que é percebida por si mesma, a chamaremos de compreensível”258.

Cite-se outro testemunho de Cícero que expõe a definição do termo segundo a filosofia do Pórtico. Em Sobre os fins dos bens e do mal III, o romano afirma pela voz de Catão:

As cognições das coisas, por sua vez, que nos seja lícito chamar compreensões, ou percepções ou, se essas palavras não agradam ou são pouco inteligíveis, catalépseis; elas, portanto, julgamos que devem ser admitidas por si próprias, porque possuem algo em si que abraça, por assim dizer, e guarda consigo a verdade ${ }^{259}$.

\footnotetext{
258 Visis non omnibus adiungebat fidem sed is solum quae propriam quandam haberent declarationem earum rerum quae viderentur; id autem visum cum ipsum per se cerneretur, comprehensibile. Cícero, Academica I,11, 41. Trad.. Lorenzo Mammì In: handout de aula, 2013, grifo nosso. Sobre a teoria o critério de verdade na "representação compreensiva", consulte-se também Carlos Lévy. Cicero academicus recherches sur les Académiques et sur la philosophie cicéronienne.,,, 1992, pp. 223 et seq.

${ }^{259}$ Rerum autem cognitiones, quas vel comprehensiones vel perceptiones vel, si haec verba aut minus placent aut minus intelleguntur, ката $\lambda \dot{\psi} \psi \varepsilon ı \varsigma$ appellemus licet, eas igitur ipsas propter se adsciscendas arbitramur, quod habeant quiddam in se quasi complexum et continens veritatem). Cicero, De finibus malorum et bonorum, III; trad. LIMA, S.C., UNICAMP, 2009, p. 426.
} 
Cícero escolhe "comprehensiones aut percepciones" para traduzir o termo grego catalépseis. Aqui, tomaremos o termo "compreensão", visto que é o termo utilizado por Agostinho no trecho que analisamos. Ademais, o termo compreensão em nosso vernáculo conota o assentimento intelectual, o que não estaria longe da doutrina do pórtico, visto que "quem percebe algo, assente imediatamente" (Cicero. Academica II, XII,38). Catalepsis, é, pois uma etapa do conhecimento que dá o testemunho fiel da verdade que se impõe à força da razão. Na cognição estoica, o "abraço cataléptico" segue a percepção do dado sensorial e é anterior ao teste feito pela razão. Liga-se ao assentimento, à phantasía, que é a representação.

A filosofia do Pórtico lança os fundamentos da epistemologia de uma doutrina que não permite a separação entre percepção e verdade, diante do que Brehier afirmará, acerca do estoicismo, que “a verdade e certeza estão na percepção" ${ }^{260}$. Em uma palavra, o conhecimento parte da empeiria das coisas para abraçar a verdade imediatamente assentida por dignidade própria e sem intermediação. Refere R. Bolzani:

Por tudo isso, para o estoicismo, a representação apreensiva é critério de verdade, o cânon que permite discernir verdadeiro e falso, apreensão do real e sua ausência. Pois o que permite distingui-la como tal, sua evidência, vem com a própria representação. O intelecto apenas reconhece essa evidência, ao dar-lhe assentimento. As representações apreensivas trazem em

260 cf. Brehier, Emile. La théorie de la connaissance consiste précisément à faire rentrer dans le sensible le domaine de la certitude et de la science que Platon en avait soigneusement écarté. La vérité et la certitude sont dans les perceptions les plus communes, et elles n'exigent aucune qualité qui dépasse celles qui appartiennent à tout homme, même aux plus ignorants; la science, il est vrai, n'appartient qu'au sage; mais elle ne sort pas pour cela du sensible, et elle reste attachée à ces perceptions communes dont elle n'est que la systématisation. Histoire de la philosophie I. L'Antique et le Moyen âge. Librairie Félix Alcan, Paris: 1928 , p. 300 
si a marca distintiva de sua verdade (cf. Academica I.§41). Portanto, é 'verdadeira e tal que não poderia tornar-se falsa' (Sextus. Adversus Mathematicos VII, 152). ${ }^{261}$

Evitando desenvolver a questão em detalhes, tracemos as linhas gerais do estudo de E. Bermon ${ }^{262}$, que tenta demonstrar como Agostinho teria se apropriado da "representação compreensiva" (phantasia kataleptiké) dando-Ihe outro sentido. Para o estudioso, Agostinho apropria-se do termo, que no dogmatismo materialista estoico sustentava o testemunho da verdade indubitável do objeto, a fim de dar ao cogito estatuto de primeiro conhecimento seguro. Mas será necessário passar pelo argumento cético para deslocar o conceito estoico de phantasia kataleptike para a concepção de "suspensão" (epoche) da nova academia, aceitando momentaneamente a acatalepsia universal; ou seja, a impossibilidade de assentir aos dados dos sentidos como critério suficiente de verdade $^{263}$. Agostinho aceita a crítica cética contra o critério de verdade da filosofia do Pórtico ${ }^{264}$, mas afasta-se em seguida do ceticismo neoacadêmico quando, para buscar a verdade, recupera a "representação compreensiva" em outra região, a saber, o intelectual ou interior.

\footnotetext{
${ }^{261}$ Bolzani Filho, R. Acadêmicos versus pirrônicos. In: sképsis, ano iv, no.7, 2011, p.20. 262 Bermon, Emmanuel. Le Cogito Dans La Pensée De Saint Augustin. cap. IV. Paris: Vrin, 2001.

${ }^{263}$ Cf. Cicero, Luculus, 13, 41 Consultar C. Lévy. Cicero academicus, 1992, p. 234.

264 cf. div. qua. $9 \mathrm{Si}$ igitur sunt imagines sensibilium falsae, quae discerni ipsis sensibus nequeunt, et nihil percipi potest nisi quod a falso discernitur, non est constitutum iudicium veritatis in sensibus. Quamobrem saluberrime admonemur averti ab hoc mundo, qui profecto corporeus est et sensibilis, et ad Deum, id est, veritatem quae intellectu et interiore mente capitur, quae semper manet et eiusdem modi est, quae non habet imaginem falsi, a qua discerni non possit, tota alacritate converti. (Logo, se são imagens falsas de coisas sensíveis que não podem ser discernidas pelos próprios sentidos, e se não pode ser percebido nada senão o que é discernido do falso, não há critério de verdade que reside/se encontra/ (constitutum) nas coisas sensíveis. Por consequência, salutarmente, somos exortados a que nos afastemos deste mundo, que certamente é corpóreo e sensível, até Deus, isto é, somos exortados a convertermos com todo ardor para a verdade que é capitada pela mente interior e pelo intelecto, que sempre permanece e deste mesmo modo é que não possui imagem falsa que não possa ser discernida)
} 
Destarte, o caminho está traçado para defesa do cogito como conhecimento seguro e imediato por catalépsis; agora, restritivo ao inteligível ${ }^{265}$.

\section{ANTECEDENTE 3: I NTUI ÇÃo I MEDI ATA}

Plotino, em Enéadas V,3[49],9, enfrenta a questão do conhecimento reflexivo da alma em oposição às contestações céticas à possibilidade de conhecimento reflexivo ${ }^{266}$. Em suma, a questão cética que dá ocasião ao tratado 49 pergunta se é possível que o conhecimento racional seja reflexivo, visto que uma parte sempre conhece outra parte, ou seja, uma relação entre sujeito do conhecimento e objeto conhecido. Plotino reconhece que realmente não é possível o conhecimento de si se dê pela razão discursiva de ordem reflexiva (caps. 1 e 5).

Evidentemente, estamos resumindo bastante a discussão do tratado, mas importa marcar que a alma conhece a si somente quando se conhece imediatamente. Isso só é possível no modo de conhecimento da intelecção, portanto, pela parte superior da alma que nunca caiu do Intelecto.

265 cf. De Gen. ad litt. XII,14,29; consulte-se Solignac e Agaesse em, BA 52, p. 578.

${ }^{266}$ cf Enéadas $\mathrm{V}, 3,5$ Pero, ¿ve ella una parte de sí misma con otra de sus partes? Si así fuese, habría, entonces, una cosa que ve y otra que es vista, lo cual no acredita, precisamente, que se vea a sí misma. Mas, ¿cómo podría afirmarse esto si ella es un todo de partes semejantes, en el que la parte que ve no difiere en modo alguno de la parte que es vista? Por lo que, si ve una parte de sí misma que es idéntica a ella, se ve también a sí misma; pues no hay diferencia alguna entre la parte que ve y la parte que es vista. O lo que es lo mismo, esa división carece de sentido. Pero, entonces, ¿cómo dividirla? Porque es claro que la división no podrá hacerse al azar. ¿Y quién podrá hacerla? ¿La realizará, acaso, el sujeto que contempla o bien el objeto que es contemplado? Pero, ¿cómo podría reconocerse ese sujeto en el objeto que es contemplado si él está contemplando como tal sujeto? Porque, evidentemente, el acto de contemplar no se da en modo alguno en el objeto contemplado, que, si se conoce a sí mismo, se conocerá como tal objeto contemplado pero no como sujeto que contempla. Tradução Ed. Gredos, 1998. 
A alma deve proceder pelo raciocínio a fim de considerar por si mesma o que é o Intelecto; pois o Intelecto vê-se a si mesmo sem necessidade de raciocínio, posto que sempre está presente a si mesma. E quanto a nós, vemos o Intelecto quando nos voltamos para ele, porque, de fato, a nossa alma encontra-se dividida em várias vidas ${ }^{267}$.

Essa parte da alma, pela íntima relação que mantém com a segunda hipóstase, pode acessar as verdades por intuição imediata; quer dizer, sem mediação dos sentidos ou da razão discursiva. Há um elo essencial que se mantém desde 0 Uno até as hipóstases subsequentes que são o Intelecto e a Alma; que, por sua vez, informam e organizam, pelos logoi producentes, formas e imagens na coisa sensível ${ }^{268}$. Tal permanência na processão (proodos) garante tanto a identidade quanto a diferença do engendrado pela diversidade das formas (species) doadas num elo de participação ${ }^{269}$. Consequentemente, a Alma, inferior à Inteligência, é continente da própria Inteligência, que a engendrou e lhe é fonte.

A condição da alma humana trilhar o conhecimento de si por via intelectiva é somente possível porque a Inteligência a engendrou por processão (proodos), desde o Uno. O Uno, por sua vez, não se estilhaça no produzido, visto que de tal engendramento produtivo opera ininterruptamente o princípio de "permanência" do engendrador no engendrado ${ }^{270}$. A questão é esclarecida pela analogia contida na relação entre o sol e os raios de luz que dele derivam. Assim como a luz depende do sol, a alma depende da fonte da qual

\footnotetext{
267 Plotino, Eneadas $\mathrm{V}, 3,9 \mathrm{El}$ alma tiene que proceder por razonamiento para considerar por sí misma lo que es la Inteligencia; en tanto la Inteligencia se ve a sí misma sin necesidad del razonamiento, puesto que siempre está presente a sí misma. En cuanto a nosotros, la vemos verdaderamente cuando nos volvemos hacia ella, porque nuestra vida se halla dividida y constituye en realidad varias vidas. Tradução Ed. Gredos.

268 cf. Enéadas $V, 1,3$.

269 cf. Enéadas V,2,2.

270 cf. Enéadas I,7,1 Assim, o Uno permanece e procede para o mundo até que tudo retorne a ele.
} 
procedeu, a saber, o Intelecto. Então, sendo a alma engendrada pelo intelecto, essa pode, pelo intelecto contido nela, conhecer como o intelecto conhece, ou seja, sem partes e presente a si mesmo.

\begin{abstract}
Mas as coisas estavam aí antes de toda a divisão e o sujeito as possui desde o momento que as contempla. Sendo assim, convém que a contemplação seja idêntica ao sujeito contemplado e, igualmente, que a inteligência e o inteligível sejam o mesmo, porque se não fossem o mesmo não haveria de modo algum a verdade e o que crê possuir somente possuiria uma impressão, que é algo diferente dos seres e não constitui certamente a verdade. ${ }^{271}$
\end{abstract}

Dado que tudo é antes de qualquer divisão e que o Intelecto contém em si todas as coisas, a contemplação é idêntica ao sujeito contemplado, do que se pode afirmar que o intelecto e o inteligível são os mesmos. Esta identidade entre sujeito do conhecimento e objeto conhecido visa garantir a verdade (refuta-se o ceticismo) na identidade entre verdade e ser, pois em caso contrário, tudo que teríamos apenas seria uma impressão, relações de representações entre dois seres. Nesse campo de representações, Plotino reconhece que o cético sempre vence, pois, não há como contornar a distância entre o que a coisa é e a sua representação na mente:

Pois, em efeito, a verdade não deve ser o conhecimento de algo distinto, mas dever ser precisamente isso que diz. Assim, a inteligência, inteligível e ser constituem uma e mesma coisa, isto é, o primeiro ser, e ainda a

\footnotetext{
${ }^{271}$ Eneadas V, 3,5 Pero las cosas estaban ahí antes que toda división y el sujeto las posee desde el momento que las contempla. Siendo esto así, conviene que la contemplación sea idéntica al objeto contemplado, e, igualmente, que sean lo mismo la Inteligencia y lo inteligible. Porque, si no fuesen lo mismo, no habría en modo alguno verdad y el que cree poseer los seres no poseería otra cosa que una impronta, que es algo diferente a los seres y no constituye ciertamente la verdad.. Tradução Ed. Gredos, 1998.
} 
primeira inteligência que possui os seres, ou melhor ainda, a inteligência que é idêntica aos seres. ${ }^{272}$

Tendo chegado à conclusão de que verdade e ser identificam-se no modo da intelecção, Plotino retoma em $\mathrm{V}, 3,9$ a relação entre verdade e racionalidade (discurso e análise): “a alma tem que proceder por raciocínio para considerar o que é a Inteligência". Então a alma chega ao intelecto pela razão discursiva, o que parece indicar que, para Plotino, a racionalidade é efeito da intuição, isto é, um modo de elevação que ainda não é verdade, mas possibilita a alma cognitiva passar ao modo intelectivo. Isso quer dizer que a alma, no modo da racionalidade, ainda não está presente a si mesma, mas pelo exercício racional desdobra o intelecto dentro dela mesma. Então, a alma une-se ao Intelecto, sempre presente a si mesmo, cujo conhecimento é “identidade entre inteligência e ser"273.

$$
* * *
$$

Agostinho, em Sobre as Duas Almas, capítulos II, III e X, insiste na cisão entre verdade e representação sensível. Diz que, quando maniqueu, era perfeitamente possível que a alma considerasse, como primeiro saber, o conhecimento de si como ser

\footnotetext{
272 Eneadas V,3,5 Pues, en efecto, la verdad no debe ser el conocimiento de algo distinto, sino que lo que dice, eso precisamente debe ser. Así, Inteligencia, inteligible y ser constituyen una y la misma cosa, esto es, el primer ser, y aun la primera inteligencia que posee los seres, o mejor todavía, la inteligencia que es idéntica a los seres. Tradução Ed. Gredos, 1998.

273 A primeira parte do parágrafo 9 parece propor algo como sublimação do corpo, pois a verdade do Intelecto não depende de nada inferior a ele. Mas, evidentemente, Plotino não defende um tipo de ascese mística, fruto de uma ruptura entre sensação e intelecção; ao contrário, deixa claro nas últimas linhas do parágrafo a legitimidade do modo de ascensão a partir do desdobramento (continuidade) das formas no ato e na potência da sensação.

Eneadas $\mathrm{V}, 3,9 \mathrm{Y}$ si no puede partir de ella, que tome la sensación plenamente desplegada en sus formas; esto es, tanto la sensación en sí misma con sus potencias como la sensación en acto manifiesta en las formas. Si lo desea, que descienda, incluso, a la potencia generadora y a las cosas que esta potencia produce; luego, que ascienda desde las últimas formas a las que también son últimas pero en sentido inverso, mejor dicho, a las formas primeras.
} 
vivente; isso por via exclusiva da parte superior da alma, chamada de mens ou intelligentia ${ }^{274}$. Parece afirmar que o conhecimento imediato de si, no modo triádico de ser-vida-intelecto, não é um procedimento da razão discursiva ou de qualquer mediação por verossimilhança; mas um conhecimento imediato dado na identidade do inteligível ao intelecto, no próprio ato da intelecção.

Destarte, assim com Plotino aceita a crítica cética contra o conceito de verdade como representação, também Agostinho faz a crítica da representação sensível, deslocando o conhecimento verdadeiro da sensação para a intelecção. Ao final, teremos maior segurança em decompor o enunciado que, a nosso ver, é a pedra fundamental de Sobre as Duas Almas 11,2: "tudo o que nós dizemos que conhecemos e que temos ciência, compreendemo-lo ou pelo sentido do corpo ou pela inteligência" (omne quod scire et nosse dicimur, aut sensu corporis, aut intelligentia nos habere comprehensum).

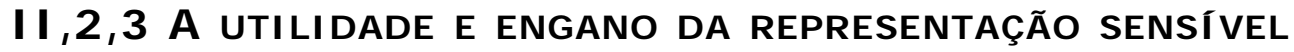
(ET BONI INSTRUUNT, ET MALI FALLUNT)

As imagens dos corpos recolhidas no espírito servem tanto aos bons, quanto aos maus ${ }^{275}$. Evidentemente, os maniqueus estão

\footnotetext{
274 Pepin expõe a filiação entre o tratado 49 e Gn. Litt. XII, 10,21 «Enfin, la connaissance de soi est totalitaire. D'une part, l'intelligence se connaît tout entière, ce qui exclut qu'elle soit composée de parties dont l'une connaîtrait les autres, mais ne pourrait connaître ni le tout, ni elle-même. .. D'outre part, elle est tout entière à se connaître, ce qui exclut qu'elle soit composée d'une partie connaissante et d'une partie connue.. De sorte qu'il n'y a pas de différance dans l'intelligence entre le connaissant e le connu, ni entre l'acte de connaissance et son object ». PEPIN, J. Une curieuse déclaration idéaliste du "De Genesi ad Litteram" de saint Augustin, et ses origines plotiniennes:: remarques sur une citation paulinienne des "Confessions" de saint Augustin. In: Revue de d'histoire et de philosophie religieuses, 1954, p.393.

275 Gn litt. XII,14,29 Tamen et per corporalem visionem, et per imagines corporalium quae demonstrantur in spiritu, et boni instruunt, et mali fallunt.
} 
incluídos no segundo grupo, pois, à diferença dos homens bons, não reconhecem que a criatura é semelhante ao Semelhante, justamente porque contém em si "os vestígios" do criador ${ }^{276}$. Contra os maniqueus, Agostinho retoma o tema da semelhança dos sensíveis (similitudo), mas para explorar a dupla possibilidade de uso das coisas semelhantes: os homens bons reconhecem a distância dos semelhantes ao criador; os maus enganam-se por ver ilusoriamente (illusio) o semelhante idêntico à sua origem (i.e: que o sol que é visto com os olhos do corpo seja o próprio Deus).

\section{Em Sobre Genesis em Sentido Literal XII,14,29, as} representações sensíveis (imagens ou fantasiae) são internalizadas por meio dos sentidos e apresentados como imagens à alma:

Aplique-se a inteligência procurando o que elas [as imagens corporais nos corpos] significam ou o que ensinam em termos de utilidade. Se encontrar, chegará ao seu fruto, e, se não encontrar, permaneça no seu juízo evitando que por alguma perniciosa temeridade deslize para um erro fatal ${ }^{277}$.

Se a alma exerce sua função mais excelente, compreende essas imagens encontrando utilidade ascensional; caso contrário, as mesmas imagens, que são autênticas imagens de corpos, servem ao engano, pois são re-imaginadas em signos vazios, produzindo uma ilusão, um "erro mortal" (errorem exitiabilem).

276 cf. Gn ad litt. lib imperf. XVI,57. Consultar E. Gilson, Introdução ao estudo de Santo Agostinho, 2007, p. 399. Afirma que «Imagem e Semelhança » é uma resignificação da teoria da representação das Ideias: o mundo criado em que vivemos é semelhante à Semelhanca (o Verbo semelhante e igual ao pai) Toda coisa criada é semelhante por partipação ao Semelhante e assim, o Verbo informa seus vestígios na criatura. Sobre a a passagem da imagem plotiniana para a "imagem igual" em Agostinho, consulte-se Koch, Isabelle. Imagene plotinienne, image augustinienne. In: Philosophiques, vol. 25, 1998.

${ }^{277} \mathrm{Gn}$. ad litt. XII,14,29. Sed adhibetur intellectus, quaerens quid illa significent vel utile doceant; et aut inveniens ad fructum suum pervenit, aut non inveniens in disceptatione se tenet, ne aliqua perniciosa temeritate prolabatur in exitiabilem errorem. Tradução de Augustino Belmonte, com alterações. 
Mais à frente, em Comentário literal de Gênesis XII,25,52, Agostinho esclarece que o procedimento enganoso ocorre a partir da alma que, pela ausência de inteligência, "aprova as coisas que são semelhantes no lugar daquelas com os quais são semelhantes":

A alma engana-se pela semelhança das coisas [corporais]; e não pelo vício delas mas pela suposição da alma que, faltando a inteligência (intelligentia deficens), aprova as coisas que são semelhantes no lugar daquelas com o qual são semelhantes. ${ }^{278}$

Em poucas palavras, Agostinho descreve o engano como uma dinâmica da percepção (visão corporal e visão intelectual). Na visão corporal, todas as coisas mantém grau de semelhança com a verdade, justamente, porque elas imitam a fonte de sua essência. $O$ intelecto deve reconhecer essa diferença entre a coisa derivada e a sua fonte para "aprovar" somente aquilo pelo qual algo é semelhante. Deve ser esclarecido que a coisa semelhante a algo não deve ser reprovada em razão de algum erro inerente a ela (vitio); ao contrário, ela é o que deveria ser, um verossimilhante. Resta que a passagem da verossimilhança dos corpos para o engano seja resultado da "deficiência do intelecto" em reconhecer a distância do semelhante à sua origem.

Quando o intelecto entende algo (intelligit) é porque a coisa é verdadeira; e se não for, não há entendimento algum, portanto, o engano do intelecto nada mais é do que uma ilusão: "uma coisa é errar no que se vê; outra, é errar porque não se vê"279. O fato percebido como "perniciosa temeridade" é recuperado aqui no campo

${ }^{278} \mathrm{Gn}$ ad litt. XII,25,52 Illuditur autem anima similitudinibus rerum, non earum vitio, sed opinionis suae, cum approbat quae similia sunt pro iis quibus similia sunt, ab intellegentia deficiens. A tradução da BAC ver similia por "imagens": "toma por imágenes auténticas las que son semejanzas de imágenes".

$279 \mathrm{Gn}$. ad. litt XII,25,52 At vero in illis intellectualibus visis non fallitur: aut enim intellegit, et verum est; aut si verum non est, non intellegit: unde aliud est in his errare quae videt, aliud ideo errare quia non vide. 
da ontologia: a figura de uma doença ganha um estatuto de ser: "privação do intelecto" (deficiens intellectus). Assim, entender o engano será sempre uma tentativa fracassada, pois não se entende o vazio ontológico do defectus.

Lembre-se que em Sobre as Duas Almas o problema de partida é aquele em que o presbítero se confessa: “Pois, se eu tivesse interrogado a mim mesmo e tivesse invocado a Deus sobre o que é viver..."280. A tarefa da alma em discernir sensíveis de inteligíveis fora obscurecida aos olhos intelectuais de Agostinho, pois, antes mesmo do entendimento da vida a priori, atentou-se às representações da vida moral, isto é, ao pecado. O erro denunciado por Agostinho na própria narrativa foi o fato de ter tomado as representações das atividades morais como dados de conhecimento espiritual da vida, isto é, elevaram-se os dados percebidos pelos "olhos carnais" (oculorum sensui) ao nível superior, aos "percebíveis pela inteligência da mente" (intelligentiam mentis perciperemos). O erro de outrora estivera fundado na atenção que se deu à extensão da alma pecadora, em suas representações sensíveis das atividades morais, em detrimento da imediata e primeira percepção interior do intelecto (mens); parte superior pelo que, indubitavelmente, a alma sabe que vive. Agostinho lamenta:

Pois eu devia ter prestado atenção não à vida apagada da alma pecadora, mas somente ao fato de que ela vive. Mas se eu pudesse ter percebido isso somente pela inteligência, eu penso que poderia ter me dado conta de que qualquer alma deveria ser preferível à luz que nós percebemos por estes mesmos olhos ${ }^{281}$

\footnotetext{
${ }^{280}$ Consultar nossa seção $1 \mathrm{I}, 2,1$

281 duab. an. II,2 Quare non ego quanto decoloratius vivat peccatrix anima, sed illud ipsum tantum quod vivat attenderem. Quod si percipere nisi intellegendo non possem, credo veniret in mentem, tanto esse quamlibet animam luci, quam per hos sentimus, oculos, praeferendam, quanto intelligentiam ipsis oculis praeferremus.
} 
Em meio ao engano e à insegurança das imagens dos corpos como critério de verdade, Agostinho encontra uma compreensão irredutível. Do mesmo modo, em A Verdadeira Religião, o cogito é evocado logo após a problematização das ilusões das imagens (phantasmata): “Onde isso é visto [a existência da verdade a partir do ato de duvidar], ali existe uma luz sem espaço local ou temporal; e sem nenhuma semelhança com os 'fantasmas' (phantasmata)"282. Percebe-se que a imaginação, dada pelos sentidos, não pode servir de critério de verdade, justamente porque é caraterístico do sensível estar associado ao falso (cf. argumentação acadêmica descrita em c. Acad. 11,5,12).

II,2,4 A vida é compreendida pelo Intelecto. A alma É UMA SUBSTÂNCI A I NCORPORAL ( COGITO)

No contexto do combate contra a gnose corporalista, o cogito agostiniano serve para identificar a alma como saber e ser de substância incorporal. A alma, assim, conhece-se como ser vivo e pensante (ser-vida-intelecto) de modo imediato, por via inteligível. Recolhe na sua tradição filosófica (tríade ser-vida-intelecto, representação compreensiva e intuição de verdade e ser) os elementos conceituais necessários para elaborar um argumento eclético e de grande engenho, que hoje chamamos de cogito agostiniano.

De início, importa observar que não há ingenuidades nem obviedades no corporalismo maniqueu. Tanto que Agostinho confessa: "naquela época [período de nove anos como auditor

282 vera relig. $X X X I X, 73$ Ubi videntur haec, ibi est lumen sine spatio locorum et temporum, et sine ullo spatiorum talium phantasmate. 
maniqueu], meu pensamento não era capaz de carregar e sustentar a questão da própria vida (ipsa vita)"283. Assim, o caminho a descoberta da substância incorporal é árdua. Há um peso que gerou o obscurecimento de um conhecimento evidente que necessita ser exposto. Acompanhemos o desenvolvimento do tratado sem esquecermos a pergunta de fundo: de onde viria a alma má?

A resposta não vem de outro lugar senão da própria alma: “Pois, se eu tivesse interrogado a mim mesmo e tivesse invocado a Deus sobre o que é viver, não poderia ter respondido, ainda que se escape aos sentidos corporais e seja absolutamente incorporal?"284. A alma interrogar-se sobre a vida é ela mesma interrogar-se sobre sua própria natureza: "tudo o que nós dizemos que conhecemos e que temos ciência, compreendemo-lo ou pelo sentido do corpo ou pela inteligência" ${ }^{285}$. A alma deve então perguntar-se sobre a origem de si mesma e o faz a partir da investigação do modo de captação do elemento que the é inerente: a vida. Em seguida, deve-se investigar por qual dos dois modos de recolhimento a alma conhece a si mesma? Ao que Agostinho responde: "Nenhuma vida e, por essa razão, nenhuma alma pode ser percebida por algum sentido do corpo, mas somente pelo intelecto" ${ }^{286}$. Com efeito, para ter ciência da alma, é necessário perceber a vida. Mas para saber com segurança que alma é, é necessário que a alma, boa ou aquela supostamente má, seja compreendida pelo intelecto. Note-se a imbricação dos elementos da tríade ser-vida-intelecto manejados interiormente, em autoanálise, a fim de buscar o primeiro conhecimento seguro de existência. O famoso cogito agostiniano, no contexto antimaniqueu,

${ }^{283}$ duab. an. II,2 Quod si tempore illo questionem de ipsa vita et de participatione viatae mea cogitatio ferre ac sustinere non posset".

284 idem.

285 duab. an 11,2 omne quod scire et nosse dicimur, aut sensu corporis, aut intelligentia nos habere comprehensum.

${ }^{286}$ Quamobrem cum omnis vita, et ob hoc omnis anima nullo corporis sensu, sed solo intellectu percipi queat. duab. an. II,2. 
não combate o ceticismo, mas o corporalismo. Nasce, portanto, do desenvolvimento dos elementos da tríade neoplatônimica ser, vida e intelecto. Aqui, "primeiro conhecimento" não significa fundação metafísica do saber, pois a alma conhece a si imediatamente participada da Vida, que necessariamente a antecede ${ }^{287}$. Disso resulta, pois, duas demarcações importantes que emergem do cogito no contexto do combate contra a gnose corporalista: 1) a alma é de natureza incorporal; 2) alma que é incorporal e sabe que vive deriva da vida em si (ipsa uita), pois a vida é percebida dentro de si e para além da alma racional, ou seja, no intelecto divino que contém a fonte de toda a vida ${ }^{288}$.

Nenhuma vida e, por essa razão, nenhuma alma pode ser percebida (percipi) por algum sentido do corpo, mas somente pelo intelecto. Assim, é absurdo e de suma demência que os próprios maniqueus afirmem que seja necessário atribuir ao bom e verdadeiro Deus coisas como o sol, a lua e todos os luminares que são percebidas pelos nossos olhos mortais. É absurdo, também, privar e recusar que Deus seja o criador de tudo o que nós percebemos. E não somente com a alma, mas com o que há de mais sublime nela, a mente e inteligência pelos quais capitamos a vida, sob qualquer forma que a conceba. ${ }^{289}$

\footnotetext{
287 cf. De beata vita II,

288 Consultar Horn, C. La vie chez Plotin In: Penser la vie. Contributions de la philosophie. Coloques interationaux. Etude de Lettres 3-4. 2008. Org. par Michel Herren et Igenborg Shussler. "La vie au niveau métaphysique réside dans l'intellect divin (nous) qui est activité de penser sous la forme de la « réflexivité » (noésis noéseos) et comme telle vie pure (Aristotle) ». Resulta que somente a parte divina da alma pode acessar tal pensamento auto-contemplativo (noésis noésos), visto que a alma inferior caída na multiplicidade da vida orgânica permanece alienada da vida em si. Consultar nossa nota anterior acerca do tratado 49 de Plotino.

${ }^{289}$ duab. an. II,2 Quamobrem cum omnis vita, et ob hoc omnis anima nullo corporis sensu, sed solo intellectu percipi queat; sol autem iste atque luna omnisque lux quae mortalibus his oculis cernitur, ab ipsis quoque Manichaeis vero et bono Deo tribuenda esse dicatur: summam esse dementiam id praedicare pertinere ad Deum, quod per corpus intuemur; quod vero non solum animo, sed ipsa sublimitate animi, mente scilicet atque intelligentia caperemus, id est, vitam, qualiscumque illa diceretur, tamen vitam, eodem Deo auctore privandam et viduandam putare. Num enim quid sit vivere, quamque secretum ab omni corporis sensu, quamque omnino incorporeum, si me ipsum invocato Deo interrogarem, respondere non possim?
} 
Agostinho dá um passo decisivo contra a doutrina maniqueia. Insiste em argumentos que demonstram a progressão falaciosa em que os maniqueus incidiram quando passaram dos sensíveis aos "espirituais" 290 . O argumento que demonstra a natureza inteligível é a priori ${ }^{291}$, pois a vida somente pode ser captada pela mente ou intelecto, parte mais alta da alma racional ${ }^{292}$, logo, a vida é de natureza incorporal. O argumento por "absurdo" visa derruir a falsa atribuição de existência ao que não pode ser (mal) e não pode viver. É logicamente inaceitável que a vida compreendida pelo intelecto não seja verdadeira, pois é evidência imediata da “compreensão cataléptica intelectual" (visum intellectualis) ${ }^{293}$, como pensamento sem qualquer "mistura" com os sensíveis ${ }^{294}$. A alma que sabe que vive (tríade: ser-vida-intelecção) em nada dependeu dos sentidos para saber-se viva, pois o pensamento de si é uma atividade

290 "espiritual" no gnosticismo maniqueu deve ser entendido como espírito de substância corporal.

291 cf. E. Gilson (2006), op.cit.,p. 99-100. Quanto a concepção de vida e alma, Gilson afirma: "o método adotado por Agostinho é essencialmente a priori. Todas as provas da distinção da alma e do corpo repousam neste princípios: as coisas nas quais o pensamento reconhece necessariamente propriedades essenciais distintas são também necessariamente distintas. Logo, será suficiente definir a alma e o corpo para saber se suas essências se confundem. Ora, por definição o corpo é uma coisa extensa por natureza (cf. Gen litt. VII,21,27), (...). Logo, a alma não é um corpo".

292 Brian Stock refere que Agostinho escreve o cogito como argumento de uma certeza irrefutável contra o probabilismo neoacadêmico em De Trinitate. A despeito das incertezas das existência temporal, a prova da existência (intelligo me esse) é um ato do intelecto em oposição aos sentidos. Nesse sentido, Stock concede que Agostinho tenha antecipado a Descartes (p. 261), embora o autor também reconheça as diferenças (p. 334 sq.). Stock, B. Augustine the reader: : meditation, self-knowledge, and the ethics of interpretation, 1998. Seguindo interpretação semelhante, consulte-se MENN, S. Descartes and Augustine. Cambridge: Cambridge University Press, 1998, p. 100 sq.

${ }^{293}$ Consultar nosso ítem "Antecedente 2..."

294 cf. Gilson, Etienne. Études Sur Le Role De La Pensée Médiévale Dans La Formation Du Système Cartésien. Paris: J. Vrin, 1930. Chapitre II, Le cogito et la tradition augustienne: «saint Augustin, comme Descartes, s'appuie sur la certitude immédiate de la pensée pour en déduire la spiritualité de l'âme: Dans les deux doctrines, c'est par un acte de la pensée pure que l'âme se saisit comme existante; pour savoir ce qu'elle est, il lui suffira d'écarter d'elle même toutes les connaissances qu'elle acquiert du dehors au moyen sen» pp. 195-196. grifo nosso. 
exclusiva da inteligência ou espírito (mens) que se conhece intuitivamente e imediatamente ${ }^{295}$.

Agora, é possível interpretar o cogito, quando evocado no combate contra a gnose, como a recusa a um tipo de representação cataléptica sensível, ainda que não se trate de combater o dogmatismo estoico, evidentemente. A ferramenta funciona para o dogmatismo corporalista-gnóstico, pois, ao recusar o "abraço" da verdade sensível, afasta-se da naturalização das imagens ilusórias

295 Nesse sentido, o conceito de uma 'intuição sensível' no interior da tríade apresentada, tomada em chave ontológico-contemporânea que desfaça os aspectos próprios da anterioridade da alma frente aos sensíveis ${ }^{295}$ parece-nos carecer de base textual tanto de Plotino quanto de Agostinho. Veja por exemplo a afirmação de John Milbank: "Para Agostinho, nossa certeza de nosso ser,vida e intelecção é uma certeza intencional aberta para essas coisas, que são tomadas enquanto realidades inerentemente transcedentais, 'excedendo' sua instanciação em nós. Assim, nenhuma res cogitans, fechada nela mesma, é aqui estabelecida". Concordamos em parte. É verdade que a tríade ser-vida-intelecção adquire algum sentido 'intencional' em Agostinho, principalmente quando a vida é ampliada pela vontade (vide nossa seção « cogito ampliado »). E de fato, não existe em Agostinho uma res cogitans no sentido moderno de um dualismo fundador da ciência. No entanto, Milbank, como bem aponta Hankey In: Augustinian Studies 32: I (2001), p. 73-74295, "esquece" de mencionar a ênfase na natureza inteligível que Agostinho concede à alma, bem como o caráter de auto-reflexibilidade imediata da mens ou intellectus. Há portanto uma transcendência irremediável, pois em Agostinho o outro não se funde no Outro nem é consituído da mesma substância, ainda que imanência e transcendência, como vimos, permaneçam como polos paradoxais de uma tensão no interior intimo meo. Em outras palavras, mantê-se, pela exigência da criação ex nihilo, a absoluta transcendência da critura e Criador e outro criado tem dependência ontológica do Ser, sem que haja partilha de essência, ou como Agostinho sempre afirma contra os maniqueus: a alma humana não provém de outra fonte criadora senão de Deus; não é da mesma natureza que a divina. Destarte, no quadro da discussão da tríade ser-vida-intelecto, é improvável que o textos de Agostinho que aqui analisamos (duab. an. II,III e $X$; vera relig. XXXIX,72-73; Gn Litt ) nos autorize a encontrar alguma indistinção temporal ('exceeding instantiation') de compreensão entre inteligível e sensível. Em acorde, consulte-se Pepin (Une curieuse déclaration idéaliste... p. 382. Pepin expõe a filiação do texto agostiniano: «Telles sont ces deux doctrines - description de la connaissance intelectuelle, traité de la connaissance e soi. La parenté dans l'allure générale, la multiplicité des recontres de détail interdisent de douter qu'Augustin les ait emprutées aux Ennéades » idem, p.393), que demonstra o 'caráter mediado do conhecimento sensível' em oposição ao caráter de infabilidade e imediaticidade do conhecimento inteligível à partir da análise comparada entre Plotino e Agostinho, respectivamente Enéadas 5,3,5 e Gn. litt XII,11,22 $(23,29)(24,51)^{295}$. Pepin defende de maneira bastante convincente a presença de duas doutrinas: 0 conhecimento intelectual e o conhecimento de si e conclui que o conhecimento de si é uma modalidade do ato do intelecto. 
(phantasmata) pela fixação de um princípio de partida: a alma de substância incorporal, que compreende-se inteligivelmente, organiza a ciência das coisas sensíveis internamente em justa posição, segundo a medida de cada um.

As imagens e os inteligíveis são recuperados na alma por meio de uma estratégia de autoanálise que presentifica a história de errâncias: momento em que a razão inverteu o valor devido a cada ser. Em suma, a estratégia do polemista contra os maniqueus consiste em desautorizar a suficiência da marca distintiva da verdade na representação sensível. Essa, por sua vez, deverá ser retomada positivamente no gênero que lhe convém. A imagem das coisas sensíveis pode conduzir o espírito em dupla orientação: servem tanto para ascensão das coisas criadas até a origem criadora quanto para, em sentido contrário, gerar uma descensão enganosa.

\section{II,3 DI SCERNINDO AS NATUREZAS.}

\section{I,3,1 A deFI NI ÇÃo de HOMEM (QUID HOMO).}

Vimos que Agostinho estabelece a alma como primeiro saber e ponto de partida de sua investigação acerca da possibilidade da existência da alma má. Resta discernir as naturezas que a alma conhece, analisando-as e valorando-as conforme os modos de percepção da alma, que, lembre-se, são dois: ou pelo intelecto ou pelo sentido corporal.

A fim de esclarecermos essa dupla via perceptiva da alma humana, tomemos dois textos em que Agostinho define o homem:

Estamos de acordo com a afirmação de que somos um composto de corpo e alma. Mas na verdade, a questão é outra: qual das duas substâncias que mencionei é a 
que constitui propriamente o homem? O homem são os dois, ou é o corpo só, ou a alma só? ${ }^{296}$

Em Sobre os Costumes da Igreja Católica e dos Maniqueus ${ }^{297}$, busca-se saber "o que é propriamente o homem" (quid sit ipse homo). Dizer que é um composto de corpo e alma parece um postulado aceito entre todos que consideram a questão. Mas a questão mais difícil é a de saber se dentre as duas substâncias existiria uma que fosse a que define propriamente. A resposta será postulada nos seguintes termos: "O corpo e a alma são duas coisas e uma sem a outra não compõe o homem. O homem não é o corpo sem alma, que o anima, nem é a alma sem o corpo para quem dá a vida. O homem é um composto entre corpo e alma". Insiste-se na imbricação das duas substâncias. Mas em outro texto, alma e corpo são substâncias com qualificações diferentes: "mas se tu queres ter a definição de alma, motivo pelo qual tu me indagas o que ela é; isso será fácil de responder: a alma, pois, me parece ser uma substância dotada de razão e apta para reinar (regere) o corpo"298.

Importa reconhecer desses dois textos dois postulados acerca da relação entre alma e corpo: primeiro - o homem é, por definição, um composto de alma e corpo, e enquanto tal, não pode ser separado de nenhuma dessas substâncias sem que ele mesmo não seja. E segundo - "a alma é apta para reger o corpo", o que

\footnotetext{
296 mor. I,4,6. inter me atque illos cum quibus nunc agitur hoc conveniat, ex anima et corpore nos esse compositos, quid est ipse homo utrumque horum quae nominavi, an corpus tantummodo an tantummodo anima. - grifo nosso.

297 Consultar R. Markus - Men: soul and body In: Armstrong, A. H. The Cambridge History of Later Greek and Early Medieval Philosophy,1967; e Gilson, Étienne. Introdução ao estudo de Santo Agostinho., 2007, pp. 96-99; Sciacca, M.F. El compuesto humano en la filosofia de San Agustín. In: Ciencia y Fe. San Miguel, Argentina, 1954.

${ }^{298}$ quan. an XIII ,22. Si autem definiri tibi animum vis, et ideo quaeris quid sit animus; facile respondeo. Nam mihi videtur esse substantia quaedam rationis particeps, regendo corpori accommodata
} 
garante qualidades distintas acerca da subordinação que uma substância deve à outra.

E. Gilson refere que Agostinho possivelmente herda do platonismo a definição de homem como "sendo nada diferente do que a alma"299. A ênfase na primazia da alma em relação ao corpo é, assim, herança do platonismo, do que não se segue que o corpo seja tomado como prisão da alma, pois insiste na unidade do homem como composto de duas substâncias: corpo e alma ${ }^{300}$.Paga-se, no entanto, o preço da indeterminação de se insistir na unidade de uma só natureza composta por duas naturezas distintas, corpo e alma. A indeterminação, contra toda a dificuldade, é mantida no interior da teoria agostiniana:

E apesar disso [composto alma e corpo], pode suceder que uma das duas coisas seja o homem e assim se chame. Então, o que é o homem a quem chamamos? (...) É difícil dar um juízo decisivo a questão e, se fosse fácil a razão, não o faria sem larga discussão. Por outro lado, não há necessidade alguma de alargar a discussão. Pois se designa por 'homem' ou a união de corpo e alma ou somente a alma. O soberano bem homem não é o soberano bem do corpo, senão que o soberano bem do homem é soberano bem dos dois, corpo e alma, ou somente da alma, isto que é a excelência do homem. ${ }^{301}$

299 Gilson, Étienne. Introdução ao estudo de Santo Agostinho, 2007, p.98. cf. Platão, Alcibíades 130c: "o homem se descobre como sendo nada diferente da alma".

300 M. F. Sciacca dará ênfase na definição de homem como unidade de substâncias. Parece dicordar de Gilson (vide nota seguinte) quando esse indica indeterminação na antropologia agostiniana. Sciacca tenta anuançar o termo 'substancia' sugerindo traduzir o termo por 'elemento'. Ainda que nos pareça acertada a interpretação geral de que Agostinho proponha a unidade antropológica, ainda assim nos parece que a unidade entre substâncias esteja no horizonte não resolvido do bispo, o que nos inclina a entender que Agostinho conceda certo campo de indeterminação a sua antropologia. cf. Sciacca, El compuesto humano en la filosofia de San Agustín, 1954.

${ }^{301}$ mor. 4.6 fieri tamen potest ut unum horum et habeatur homo et vocetur.Quid ergo hominem dicimus? (...) Difficile est istam controversiam diiudicare, aut si ratione facile, oratione longum est; quem laborem ac moram suscipere ac subire 
A indeterminação é percebida e reconhecida, contudo não se retrocede $\mathrm{e}^{302}$; ao contrário, mantém a dificuldade, afirmando peremptoriamente a unidade do composto. Não é tema nosso examinar profundamente as causas dessa indeterminação no interior do pensamento de Agostinho. Apenas, revisamos a questão a fim de posicionarmos a alma como regente dos sentidos corporais e, consequentemente, receptora das imagens corporais, bem como apta para acessar conteúdos inteligíveis provindos da mente divina. Tal inderteminação é, pois, indicativo do postulado essencial do tratado: a alma está situada em região intermediária no quadro ontológico das criaturas.

\section{II ,3,2 Percepção dos Corpos.}

Agostinho pode agora repor a questão da natureza dos corpos, a fim de compreendê-las interiormente, por "participação" na seguinte cadeia causal:

Eu deveria ter duvidado que alguma alma viesse dele? Mas nem mesmo um homem tão ignorante quanto jovem, como de fato eu era, teria alguma dúvida que tanto a alma quanto qualquer corpo viesse dele. Assim seria se eu tivesse pensado com piedade e com cuidado sobre o que é a forma e o que é o ser formado (forma et formatum); o que é a beleza $\left(\right.$ species $^{303}$ )e o que é

non opus est. Sive enim utrumque sive corpus solum sive anima sola nomen hominis teneat, non est hominis optimum quod optimum est corporis, sed quod aut corpori simul et animae aut soli animae optimum est, id est hominis optimum.

302 Sobre a questão, consulte-se cf. Gilson, op.cit.(2006) pp. 98 seq. e pp. 212220, As indeterminações agostinianas (distinção entre emanção plotiniana e criação ex nihilo cristã).

${ }^{303}$ Cf. J. Pegnon, In: Augustine, Saint. Fuvres De Saint Augustin. Paris: Desclée de Brouwer, 1936, vol. 8, pp. 486-488. Para Pegnon, forma e specie se movem sobre o mesmo campo metafísico, no entanto não são idênticos. Specie refere-se mais aos aspectos exteriores das coisas, portanto traduzido por 'beleza'. 
um ser revestido de beleza e, finalmente, qual dessas coisas é a causa da outra. ${ }^{304}$

Percebe-se que o termo "participação" visa menos desenvolver uma teoria das formas do que ressaltar os lugares próprios de cada coisa no quadro das naturezas ordenadas segundo sua dependência do criador, fonte de toda forma e beleza. Na cosmologia agostiniana, portanto, as formas intelectuais têm apenas primazia sobre as sensíveis, mas de maneira alguma prescindem delas; ao contrário, as coisas sensíveis recebem a forma, portanto são informadas de certa perfeição, enquanto que a forma mesma permanece imutável ${ }^{305}$.

Evidencia-se, desde as primeiras linhas do tratado, o conceito da "participação" como relação de dependência do ser ao criador. No entanto, mantendo o princípio de alteridade do criador ao criado, Agostinho traz o conceito de participação bem cerrado ao princípio de sustentação e permanência de todas as coisas pela derivação e contínua manutenção do princípio criador na criatura.

Em outro texto esclarecedor, a Verdadeira Religião (391), Agostinho expõe, frente à questão da defectibilidade do ser criado a partir do nada (ex nihilo), as condições de possibilidades das coisas criadas manterem sua essência e forma ${ }^{306}$.

\footnotetext{
304 duab. anim. 2.3: egone tandem, quod ab eo esset quaecumque anima, dubitarem? Ego vero non modo de anima, sed de quovis etiam corpore, quin ab ipso esset, nihil omnino, ne tum quidem, homo scilicet illius imperitiae atque illius aetatis ambigerem, si forma quid esset quidve formatum, quid species et quid indutum specie, deinde quid horum cui causa esset, pie cauteque cogitarem.

305 Sobre a fortuna platônica em Agostinho e depois de Agostinho, consulte-se Cadernos de Trabalho CEPAME 1993 (II) 1. Des ideis. Question XLVI In div. qu.

306 Agostinho não defende um engendramento (próodos) do Uno ao ser como desdobramento substancial como, por exemplo, poderia ser encontrado em Plotino, nem recai num dualismo de dois mundos, onde a realidade inteligível supralunar é mantida autonomamente separada de sua cópia e simulacro. É importante notar que Agostinho se concentra na relação de subordinação, pela qual a condição de existência do ser criado depende da conservação que Deus confere à criatura.
} 


\title{
I I ,3,3 DefeCti BI LI DADE E CONSERVAÇÃO dOS SERES
}

\begin{abstract}
Mas o que tu dizes para mim: Por que as coisas desfalecem (deficiunt)? Por que são mutáveis? [Respondo:] Porque não são o sumo ser. E por quê? Porque elas são inferiores, e isto é fato. E quem as fez? Aquele que é o sumo ser. E quem é este? É Deus, imutável Trindade, que pela sabedoria fez todas as coisas e as conserva com suma bondade. Para quê ele as fez? Para que fossem. E qualquer que seja isto é bom, porque o sumo bem é sumo ser. A partir do quê as fez? A partir do nada. Porque tudo o que é, possui necessariamente beleza (species), e ainda que seja um minúsculo bem, sempre será um bem e de Deus será. Porque a suma beleza é o sumo bem, as menores belezas é o menor bem. Assim todo o bem ou é Deus ou provém dele. Portanto as mínimas espécies provêm de Deus. E aquilo que se diz da beleza, igualmente da forma pode ser dito. Não é por acaso, em efeito, que no louvar se use tanto o termo speciosissimum quanto formosissimum. Portanto, de onde Deus criou todas as coisas não há nem beleza, nem forma, porque nada é do que é nada. $E$, o que em comparação com o perfeito é chamado de informe tem alguma forma, ainda que exígua e incompleta e não é nada; e por isso, enquanto é, não é senão a partir de Deus. ${ }^{307}$
\end{abstract}

A questão que nos importa na análise de Sobre as Duas Almas é notar como Agostinho não faz a crítica dos sensíveis por

\footnotetext{
${ }^{307}$ Vera relig. XVIII,35 Sed dicis mihi: Quare deficiunt? Quia mutabilia sunt. Quare mutabilia sunt? Quia non summe sunt. Quare non summe sunt? Quia inferiora sunt eo a quo facta sunt. Quis ea fecit? Qui summe est. Quis hic est? Deus incommutabilis Trinitas, quoniam et per summam Sapientiam ea fecit, et summa benignitate conservat. Cur ea fecit? Ut essent. Ipsum enim quantumcumque esse, bonum est; quia summum bonum est summe esse. Unde fecit? Ex nihilo. Quoniam quidquid est, quantulacumque specie sit necesse est; ita etsi minimum bonum, tamen bonum erit, et ex Deo erit. Nam quoniam summa species summum bonum est, minima species minimum bonum est. Omne autem bonum, aut Deus, aut ex Deo. Ergo ex Deo est etiam minima species. Sane quod de specie, hoc etiam de forma dici potest. Neque enim frustra tam speciosissimum, quam etiam formosissimum in laude ponitur. Id igitur est, unde fecit Deus omnia, quod nullam speciem habet, nullamque formam; quod nihil est aliud quam nihil. Nam illud quod in comparatione perfectorum informe dicitur, si habet aliquid formae, quamvis exiguum, quamvis inchoatum, nondum est nihil, ac per hoc id quoque in quantum est, non est nisi ex Deo.
} 
mera desqualificação de capacidade deles em conter em si (in re) beleza e forma.

A preocupação recairá sobre o estado de dependência ontológica (species et forma) que as coisas criadas tributam ao seu princípio criador absolutamente simples ${ }^{308}$. “É Deus, imutável Trindade, que pela sabedoria fez todas as coisas e as conserva com suma bondade". Com efeito, importantes alcances são possibilitados pela "conservação" divina. A coisa é diferente do nada, pois é algo na medida em que depende do sumo ser. A mutabilidade que parte (ex) do nada (nihilo) mantém alguma forma, porque é conservada na propriedade de ser defectível; e fora dessa dependência ontológica, a coisa perde sua legitimidade de ser (essência), porque já não seria ser conservada. Portanto, as coisas organizadas em beleza e forma são mantidas (conservare) pelo que lhe é superior. $E$ ainda que as coisas sejam exíguas e defectíveis, elas mantêm alguma forma (habet aliquid formae, quamvis exiguum) e não pode ser nada.

É necessário que o pensamento transcenda as representações sensíveis, pois, para além da beleza e dos objetos formados, existirá o sumo ser. Não se trata tanto de buscar a ideia paralela e autônoma, situada no supra lugar, mas de buscar nas formas temporais os vestígios do Ser criador. Agostinho explora mais a dependência (por conservação) que todas as coisas criadas mantêm com o Uno-Deus, pois, o sumo ser garante por si mesmo que o Uno esteja presente no inferior criado, sem que ele mesmo seja diminuído de seu ser e sem que ele seja confundido com as menores criaturas que dele dependem.

\footnotetext{
${ }^{308}$ Sobre o manejo de elementos neoplatônicos no livro, consulte-se J. Lossl. The One (unum) - A guiding concept in De vera religione. In: Revue d'Etudes Augustinienne, 40, 1944. O estudioso defende a influência porfiriana em vera relig. À diferença de Plotino para quem o unum estaria "além do ser e do nada", Porfírio apresenta alternativa de um unum unificador (conserva-mantém) dos seres criados. p. 92.
} 


\section{II,3,4 A VIDA dOS PEQUENOS É SUPERIOR AOS CORPOS DOS} ASTROS.

Então, perguntaria o maniqueu: como compreender a ordem hierárquica da vida a partir dos organismos ínfimos, e até repugnantes como a vida das moscas? Afinal, o senso comum concordaria que nos insetos não há beleza alguma. Não seria evidente que a vida da mosca vale menos que astros grandiosos como o Sol e a Lua? Ao passo que Agostinho responderia sem titubear: não, ao contrário, a evidência mostra que a vida da mosca é mais excelente do que o Sol! O exemplo limite do inseto, que na escala dos viventes é ínfimo e, ainda assim, é mais excelente do que o maior ser na escala dos inorgânicos, serve para evidenciar a radicalidade da escala essencial proposta por Agostinho. De fato, a vida da mosca manifesta a atividade da alma sobre o corpo. Os corpos celestes como sol e a lua, venerados pelos maniqueus como bens máximos, continentes das luzes liberadas dos corpos pelas almas dos maniqueus "eleitos", são bens inferiores se comparados às almas de pequenos insetos como as moscas. A pequenez do inseto contrasta com a magnitude espacial dos corpos celestes, e, no entanto, a evidência da superioridade da vida inteligível comanda que a alma da mosca seja considerada muito mais sublime que o sol.

Não se trata mais, evidentemente, de uma alma pensante (animus) que pensa imediatamente a vida, enquanto primeiro conhecimento. Então, como se dá a percepção da vida em outros seres para permitir Agostinho afirmar algo aparentemente contrário ao senso comum (que o inseto seja preferível ao sol)? Dar-se-á graças à participação das criaturas à perfeição do Criador e à capacidade da alma humana perceber a beleza das coisas sensíveis. $O$ homem pode perceber formas e belezas inerentes aos seres 
orgânicos, pois é natureza da atividade da alma que a vida seja comunicada ao corpo dos seres viventes, pelos "seus movimentos espontâneos e vividos, pelas suas atividades, seu caráter vivo e imortal" (duab. an. III, 3,, de anima conqueror, de spontaneo et vivido motu, de actu, de vita, de immortalitate). A compreensão da vida orgânica procede em dois momentos 309 lógicos, não necessariamente cronológicos: primeiro, pelo conhecimento necessário e imediato da vida pura enquanto ser pensante, pelo qual compreende que participa da Vida; segundo, mediante ${ }^{310}$ a percepção sensorial da vida orgânica a partir das atividades de seres viventes:

Pois, pergunta-se: o que faz esses membros tão exíguos crescerem? O que leva um corpo ínfimo para aqui e ali conforme seu apetite natural? O que move seus pés ritmicamente quando está correndo? O que regula e faz vibrar suas asas quando está voando? ${ }^{311}$

Assim, o homem pode inferir por analogia 312 ao seu conhecimento intuitivo de vida, pensamento e existência, que exista vida comunicada aos corpos de outros seres, pois percebe características de sua própria vida nos movimentos dos outros viventes. Em A Verdadeira Religião, Agostinho enfatiza a beleza da atividade da vida orgânica dos insetos, que manifesta em maior grau

\footnotetext{
${ }^{309}$ S. Menn, seguindo Gilson (vide nota anterior), relaciona Agostinho e Descartes à mesma esteira metafísica de Platão. Assim, os fenômenos sensíveis são o passivo da atividade conceitual do intelecto, isto é, passagem do conceito à coisa sensível. Cite-se: "soul's reflection on itself is the necessary point of departure for coming to a... purely intellectual understanding of the realities underlying sensible phenomena". MENN, S. Descartes and Augustine. Cambridge: Cambridge University Press, 1998, p.112.

310 Sobre o caráter mediado do conhecimento sensível, cuja imagem do objeto é representação acataléptica, consulte Pepin: "II resort de cet examen que, pour Plotin comme pour Augustin, la connaissance sensible est une connaissance mediate" Pepin, Une curieuse.,p. 383; bem como Bermon, Le cogito., cap. IV.

${ }^{311}$ duab. an. IV,4 Quaeritur enim, quid illa membra tam exigua vegetet, quid huc atque illuc pro naturali appetitu tantillum corpusculum ducat, quid currentis pedes in numerum moveat, quid volantis pennulas moderetur ac vibret.

312 cf. Trin. VIII, 6,9. ex nostro credimus quem non novimus. Sobre o 'argumento de analogia' em Agostinho e sua fortuna, consulte-se Mathews, G. Augustine on Reasoning from One's Own Case. In: Medieval Philosophy and Theology. 1988.
} 
a unidade criadora quando comparada aos seres inorgânicos. De fato, o corpo simétrico e proporcional já aponta para unidade criadora; no entanto, as atividades biológicas, que animam os corpos desses pequeninos e são causas dos movimentos corporais motivados pelo apetite natural por conservação, serão ainda mais belas quando comparadas a um simples corpo. Então, a Vida inteligível é manifesta nos corpos vivificados por derivação; e os homens, compostos de alma e corpo, podem perceber com os seus órgãos sensíveis oculares, a beleza específica dos pequenos corpos animados dos organismos vivos. Os organismos ínfimos, como insetos, mantêm suas atividades em razão da participação da unidade criadora, que é a Vida:

É preciso reconhecer que é preferível encontrar um homem a chorar, a um insetozinho a se alegrar. E contudo, eu posso fazer longo elogio ao inseto se considero o brilho de suas cores, a figura roliça do seu corpo, as proporções dos membros dianteiros, médios e traseiros, que mantêm toda uma exigência de unidade permitida a esse humilde grau de ser. Nele, não há parte alguma que não tenha em face outra correspondente, na mesma dimensão. E o que dizer da vida que anima esse pequenino corpo? E o modo como se movimenta em cadência? Como procura o que the convém, ultrapassando ou evitando os obstáculos, quanto pode. Tudo subordina a seu único instinto de conservação. Recorda ele a suma unidade criadora de todas as obras de natureza, muito mais do que um ser inorgânico. E digo isso de um insetozinho que de certa forma possui vida só em pequena escala ${ }^{313}$

313 vera relig. XLI,77 Necesse est autem fateamur meliorem esse hominem plorantem, quam laetantem vermiculum: et tamen vermiculi laudem sine ullo mendacio copiose possum dicere, considerans nitorem coloris, figuram teretem corporis, priora cum mediis, media cum posterioribus congruentia, et unitatis appetentiam pro suae naturae humilitate servantia; nihil ex una parte formatum, quod non ex altera parili dimensione respondeat. Quid iam de anima ipsa dicam vegetante modulum corporis sui, quomodo eum numerose moveat, quomodo appetat convenientia, quomodo vincat aut caveat obsistentia quantum potest, et ad unum sensum incolumitatis referens omnia, unitatem illam conditricem naturarum 
Pode-se afirmar, novamente em concordância com os que "pensam com seriedade a questão" ${ }^{314}$, que as almas das moscas são superiores aos grandes corpos luminosos como o sol e a lua, fato mesmo inconcebível aos maniqueus, que veneram tais astros por serem receptáculos de luz e bondade.

Destarte, a reabilitação dos corpos pela percepção da beleza inerente à proporção é útil para insistir na cadeia hierárquica dos seres, cujas vidas concretas são derivadas da Vida; e não o contrário, que é justamente o modo equivocado das doutrinas corporalistas. Assim, de maneira breve, mas seguramente decisiva, Agostinho opõe o modo de valoração corporalista das coisas sensíveis à noção de participação dos inteligíveis ${ }^{315}$. A rápida referência à participação dos corpos nas formas divinas ${ }^{316}$ serve para indicar, por comparação, o caráter superior dos bens não sensíveis, mais especificamente, a superioridade da alma inteligível sobre os corpos celestes que os maniqueus reputam dignos de veneração.

Adiante, a valoração positiva das naturezas corporais será retomada para enfatizar que o pecado não é jurisdição de natureza, e sim da livre vontade. Por ora, a ênfase do tratado repousa, pois, declaradamente, apenas sobre um dos elementos do composto, a alma. Por conseguinte, as representações sensíveis corporais são evocadas para mostrar seu caráter inferior, face à necessidade, quanto à alma, de buscar pela sua essência de verdade evidente e clara.

omnium, multo evidentius quam corpore insinuet? Loquor de vermiculo animante qualicumque. Tradução. Ed. Paulus, 2002.

${ }^{314}$ Referência aos doutos filósofos.

315 cf. mor. IV. Ver nota anterior.

316 cf. Bouton-Touboulic, Anne-Isabelle. L'ordre Caché: La Notion D'ordre Chez Saint Augustin. 2004. p. 115-117, nota 62. 


\section{II ,3,5 OS Ví CI OS DA ALMA SÃo SUPERI ORES À LUZ SENSÍ VEL}

Em Livre Arbítrio II,19,50, Agostinho classifica os bens em três graus: grandes, medianos e inferiores. E por todos eles, Deus deve ser louvado, pois mesmo o mínimo bem, ainda que corporal e sem utilidade para a vida humana, é feitura dele. As virtudes estão contidas entre aqueles que são grandes bens e, por isso, não podem ser mal utilizados. Em Sobre as Duas Almas $\mathrm{V}$, o problema é discernir o oposto da virtude, isto é, o vício. Qual o lugar ontológico do vício?

Dado que injustiça, intemperança e os demais vícios da alma não são percebidos pelos sentidos, mas apenas pelo intelecto, e apesar desses bens serem detestáveis e condenáveis, segue que, por serem inteligíveis, eles superam essa luz [sensível], ainda que seja algo digno de louvor no seu próprio gênero. ${ }^{317}$

Se a virtude está mais perto do Ser, e pode ser compreendida sem os sensíveis, poderia o vício ser compreendido pelo mesmo modo? Aparentemente, a injustiça é contada como um bem inteligível, ainda que não se diga, infere-se que seja em grau menor de bem do que virtude, mas ainda um bem que deve ser devidamente classificada; cada qual "em seu gênero" (in suo genere). Os vícios da alma, sendo bem, podem diminuir a essência da virtude?

As respostas seguem a distinção entre o louvor $e$ excelência, pois é certo que a injustiça, como vício, é digna de reprovação, enquanto o sol, como ser corporal, é digno de louvor no seu próprio gênero. Mas, então, obriga-se a aceitar que "nem tudo o que nós louvamos deva ser preferido a tudo que condenamos", visto que o sol que nós louvamos, enquanto gênero de coisas sensíveis,

\footnotetext{
317 duab. an. V,5 cum iniustitia et intemperantia caeteraque animi vitia non sentiantur, sed intellegantur; quomodo fiat ut etiam ista, quae detestamur et damnanda censemus, tamen quoniam intellegibilia sunt, anteire hanc lucem queant, cum in suo genere ista laudanda sit.
} 
não pode ser preferível ao vício que é percebido pelo intelecto. É uma questão de definição de gênero: “cada realidade deve ser considerada em seu próprio gênero" (In suo enim genere quidque considerandum est. duab. an. V,5).

No entanto, a despeito de ser preferida ao sol, a alma viciosa deve ser condenada pela justiça divina, pois ela não é superior pelo fato de ser viciosa, mas pelo fato que vive e é alma, e disso não se pode duvidar. Destarte, Agostinho afirma: "nós devemos considerar cada coisa em seu próprio gênero". Por exemplo, pode-se louvar o bom sapateiro em detrimento do mal advogado, no entanto preferimos muito mais o advogado como gênero intelectualmente superior ao artesão, isso, sem prejuízo do devido louvor dado ao artesão que cumpre bem o seu papel no gênero que lhe convém. $A$ intenção é, pois, salvaguardar a superioridade da alma independentemente dela ser continente de vícios. A alma, mesmo aquela viciada, continua sendo inteligível e não decai do seu gênero, ainda que continente de injustiça e intemperança, por exemplo, não perde sua natureza.

Torna-se inevitável, no entanto, que se pense o vício em si mesmo; aliás, Agostinho reconhece a seriedade da questão, assumindo que algum estudioso maniqueu, cauto e vigilante, adjetivos generosos diga-se, pudesse propor tal questão. Como pode ser que o vício, percebido pelo intelecto, tenha Deus como criador? Assim, Deus seria o próprio autor dos vícios? Agostinho confessa que a construção do conceito "é difícil e árdua para discernir" (difficile esse ad dignoscendum atque arduum confiterer) e lamenta que, quando auditor maniqueu, não tivesse tido a capacidade de desenvolver a questão que, uma vez não resolvida, conduziu-o necessariamente ao erro de considerar o sensível superior ao inteligível. Tal inversão na cadeia hierárquica de naturezas levaria ao 
cabo que o Deus fosse o próprio o autor dos vícios. É sobre exatamente essa teodiceia que se funda o maniqueísmo, cuja solução, sabe-se, supõe um dualismo de substâncias agônicas e antagônicas.

\section{I ,3,6 I RREDUTI BI LI DADE DO SER PELO SEU OPOSTO.}

Então, em que medida, esse vício desqualifica a alma na ordem hierárquica do ser? Agostinho propõe que a questão seja tomada por uma estratégia que parta das evidências sensíveis: da ciência dos sensíveis ao conhecimento inteligível. Justifica-se: apesar de que o conhecimento sensível não seja o mais seguro, ainda assim, pela complexidade do problema, o conhecimento sensível é útil pelo caráter mais familiar: após ter encontrado algum princípio possivelmente verdadeiro entre os exemplos da sensibilidade, segue a aplicação aos inteligíveis, e mostrando-se coerente, a verdade anteriormente insegura torna-se fortalecida pela garantia da imutabilidade dos inteligíveis.

O enfrentamento da questão se inicia pela possibilidade de nomear como coisas sensíveis não somente o que se dá aos sentidos, como também as coisas que não se dão, por exemplo, as trevas para os olhos e o silêncio para os ouvidos; e, aplicando para as coisas inteligíveis, a ignorância para os olhos da mente. A fim de recusar que tais privações sejam referidas a Deus, passa-se simplesmente a comparar pela positividade do ser e não pela negação do ser, pois está suficientemente demonstrado que, por exemplo, o ouro seja inferior à sabedoria, mas não há absolutamente nenhuma diferença entre as suas respectivas privações, isto é, entre o não-ouro e a nãosabedoria (ignorância); ademais, ainda que se conceda nomear o não-ouro como sensível e a ignorância por inteligível, isso pouco 
importa, pois é suficiente que se estabeleça que não haja possibilidade de qualquer comparação entre privações, logo, não será possível estabelecer alguma hierarquia. Assim, ainda que se conceda chamar as trevas de coisa sensível, em nada abalará o estabelecimento da superioridade da alma se comparada aos astros, mesmo que essa seja continente de vícios.

\begin{abstract}
Mas eu poderia ter dissolvido toda a questão por uma fácil divisão, e imediatamente poderia ter aprovado com boa atenção: que pela lei divina as substâncias inteligíveis verdadeiras são preferíveis as substâncias sensíveis, e não a privação dessas substâncias (substantiarum defectus). E a despeito [da privação], deveria ter chamado essas de inteligíveis e aquelas de sensíveis ${ }^{318}$.
\end{abstract}

Obviamente, mesmo que o não-ouro e a não-virtude sejam equivalentes, não se conclui daí que se deva valorar mais o ouro do que a virtude. É evidente que a privação da virtude é moralmente mais grave que a privação do ouro, mas o que se comparou nesta constatação não foram as negações; na verdade, comparou-se, por assim dizer, as substâncias positivas, que simplesmente são. Assim como as trevas, como privação da luz corpórea, não destituem a natureza da luz sensível; muito menos, os vícios, como privação da virtude, podem usurpar a natureza inteligível da alma, posto que a alma é irredutível ao erro e ao vício. Irredutibilidade garantida pelo conhecimento evidente da alma que se sabe inteligível e viva por participação. Agostinho pode, então, confessar que outrora caíra na sedução gnóstica, porque se ateve à comparação do que era

\footnotetext{
318 duab. an. VI,7 sed totam quaestionem facili divisione dissolverem, statimque approbarem bene attendentibus, substantias intellegibiles sensibilibus substantiis divina et incorrupta veritatis lege praeponi, non earum substantiarum defectus; quamvis hos intellegibiles, illos sensibiles appellare vellemus.
} 
"percebido por privação" (per defectum perciperentur) ${ }^{319}$; maneira agostiniana de dizer que tomou o não-ser pelo ser.

Diz que se tivesse comparado o conhecimento das coisas percebidas pelos sentidos à própria inteligência, de maneira alguma se poderia aceitar que algum gênero de alma não pudesse ser incluído entre as coisas inteligíveis, pois:

As almas não são, senão enquanto vivem. Ainda que sejam consideradas viciosas pelo fato de que estão privadas (defectus), e são viciosas porque estão privadas da virtude, elas seriam almas não pelo fato de uma deficiência (defectus), mas porque vivem. ${ }^{320}$

Concluindo, o não-ser (ou os vícios) é tomado pelos gnósticos como dado de determinação em detrimento do reto juízo que compara as coisas que simplesmente são, e participam do ser para continuar sendo. É necessário que se entenda, e nos parece que Agostinho o descobre de maneira dolorosa ${ }^{321}$, que certa "sensação da ausência" (per defectum perciperentur) de coisas que os sentidos ou a inteligência possuem fundamenta-se em nada menos do que no reconhecimento da essência da coisa, e não no contrário da essência, que nada é:

\footnotetext{
${ }^{319}$ duab. an. VI,8 Non usque adeo, quaeso, caecitas mentis suppliciaque augeantur animorum, ut haec homines non intellegant. Sed quoquo modo illorum error aut pertinacia sese haberet, his ego fretus armatusque rationibus, credo cum ad eos rem ita consideratam perspectamque detulissem, et cum his placide contulissem, vererer ne mihi quisquam eorum alicuius momenti esse videretur, si aut intellectum, aut ea quae intellectu non per defectum perciperentur, sensui conaretur praeferre, aut saltem comparare corporeo, vel his rebus quae ad eumdem sensum cognoscendae similiter pertinerent.

320 duab. an. VI,8 Siquidem animae non alio essent, nisi quo viverent. Licet enim per defectum intellegerentur vitiosae, quia virtutis egestate vitiosae; non tamen per defectum animae, quia vivendo animae.

321 cf. duab. an. VI,6 Recurrerem in me, prosternerer Deo, alte ingemiscerem, quaerens ne me in medio spatio, quo certis rationibus promovissem, haberere pateretur; - [naquela época] teria me recolhido em mim mesmo, teria prostradome diante de Deus, teria gemido profundamente, pedindo que não tivesse que sofrer no meio do caminho, de onde já havia avançado a argumentos certos.
} 
Assim estabelecido, como este homem [maniqueu] ou qualquer outro ousaria me contestar que as almas, ainda que as quisessem más, estivessem contadas entre os inteligíveis pelo fato mesmo que são almas e não são conhecidas por meio de uma privação (defectus)? Com efeito elas não seriam almas senão porque vivem. Certamente, é pela privação que são entendidas viciosas, porque é pela falta da virtude que são viciosas; mas não são almas por uma privação, porque é pela vida que elas são almas. ${ }^{322}$

E ainda que se supusesse a existência de uma alma má, essa seria contada necessariamente entre os inteligíveis, visto que o único fator de determinação da alma é a vida compreendida pelo intelecto. Assim, não há nenhum fator alheio à vida capaz de diminuir seu valor ontológico.

De fato, Agostinho, pode retomar a questão geral da natureza da alma a partir dos fundamentos postos nos primeiros capítulos do tratado para afirmar que a certeza de se saber um ser vivente pela via da parte da alma mais excelente, o intelecto, garante que a alma seja alma, não porque tal alma careça de virtude e seja viciosa, mas somente na medida em que se sabe como vivente (cogito) e participante da Vida ${ }^{323}$. Trata-se de um argumento de irredutibilidade do ser recorrente no pensamento do hiponense. A fim de esclarecer a força do argumento no pensamento de Agostinho, tomemos o Sobre a Imortalidade da Alma (387) para melhor esclarecer as condições de pensar um "contrário à verdade" (At si

\footnotetext{
322 duab. an. VI,8 Quo constituto, quando ille mihi vel quisquam negare auderet, animas quantum vellet malas, tamen quoniam animae essent, intellegibilium rerum numero contineri, neque illas per defectum intellegi? Siquidem animae non alio essent, nisi quo viverent. Licet enim per defectum intellegerentur vitiosae, quia virtutis egestate vitiosae; non tamen per defectum animae, quia vivendo animae.

( Nec fieri potest ut vitae praesentia sit causa deficiendi; cum tanto quidque deficiat, quanto deseritur a vita) E não pode ser seja pela presença da vida que elas são privadas, porque somente é privada na medida em que a vida a abandona.

323 cf. duab. an. II,2 questionem de ipsa vita et de participacione vitae mea cogitatio.
} 
veritati contrarium ita quaeramus. I mm. an. XII,19) como verificação da irredutibilidade da natureza inteligível:

\begin{abstract}
Busquemos um contrário à verdade, não enquanto é verdade, senão enquanto é o supremo e máximo ser, se bem que algo é na medida em que é verdade. Com efeito, chamamos de verdade isto pelo qual todas as coisas são verdadeiras em seu ser e na medida em que são verdadeiras. Mas não evitarei um argumento que o demonstra de maneiras mais evidente. Se nenhuma essência, na medida em que é essência, tem um contrário, muito menos tem um contrário àquela primeira essência que se chama Verdade, enquanto é a Essência. A premissa é verdadeira: em efeito, uma essência é essência porque é; e nesse sentido, nada há contrário ao ser senão não ser, logo nada é contrário à essência. De nenhum modo, pois, algo é que seja contrário à substância, que é o ser máximo e originário. ${ }^{324}$
\end{abstract}

Intenta-se, igualmente, demonstrar a total impossibilidade de se determinar a essência da alma por si mesma ou mesmo pelo contrário de sua determinação essencial. Parte-se de uma estratégia bem próxima ao que está sendo desenvolvida em Sobre As Duas Almas, com a diferença que ali se enfatiza a essência da verdade dependente da fonte originária, o Ser supremo. Assim, a evidência primeira de se saber vivo por via a priori dos sentidos, mediante a parte superior da alma, chamada de inteligência ou mente, depende da participação que a proposição verdadeira possui da verdade, isto é, do quanto aquilo que é verdadeiro depende do "máximo e supremo

\footnotetext{
${ }^{324}$ De immortalitate animaie XII, 19 At si veritati contrarium ita quaeramus, non in quantum veritas est, sed in quantum summe maximeque est, quamquam in tantum est idipsum in quantum est veritas; siquidem veritatem eam dicimus qua vera sunt omnia in quantumcumque sunt, in tantum autem sunt in quantum vera sunt; tamen nullo modo id defugerim, quod mihi evidentius suffragatur. Nam si nulla essentia in quantum essentia est, aliquid habet contrarium, multo minus habet contrarium prima illa essentia, quae dicitur veritas, in quantum essentia est. Primum autem verum est. Omnis enim essentia non ob aliud essentia est, nisi quia est. Esse autem non habet contrarium, nisi non esse: unde nihil est essentiae contrarium. Nullo modo igitur res ulla esse potest contraria illi substantiae, quae maxime ac primitus est.
} 
ser". Logo, a certeza do "eu sei que vivo" e, por conseguinte, a determinação da alma como substância inteligível é inerente ao grau de participação ontológica da "primeira essência-verdade", da qual participa. A premissa na qual se fundamenta a possibilidade do verdadeiro se baseia no que segue: "em efeito, uma essência é essência porque é", princípio de onde se conclui que "nesse sentido, nada há contrário ao ser senão o não-ser, logo nada é contrário à essência".

De fato, em Solilóquios II, XII,23, no contexto dos argumentos em favor da imortalidade da alma, Agostinho já enfrentara a questão da possibilidade da redução da essência pelo seu contrário. Ali, com a ajuda de "grandes filósofos", propõe a superação do alcance da verdade por semelhança (similitudine), visando estabelecer que a essência, por definição e necessidade, não admite o não-ser; em outras palavras, a determinação do ser não admite a sua negação. Logo, qualquer que seja a negação do ser, em nada se diminui a determinação do ser, isto é, a essência propriamente dita. Mas Agostinho vai além do princípio dialético platônico que, em suma, visa afirmar que a essência da vida não admite a negação, isto é, a morte ${ }^{325}$. Ele acrescenta: o pensamento que sabe que vive como primeira intuição descobre como ser participado da Vida verdadeira e suprema. Gilson analisa o trecho de Sobre a Imortalidade da Alma XII, 19:

\footnotetext{
325 cf. Plotino, Enéadas 4.7.9. Segundo, Horn, o termo "participação da vida" origina-se sob influência que Plotino teria recebido do texto platônico no Fédon 103c-107b. Platão defende que 'a alma deve ser ela mesma fonte da vida' - ali, alma tem vida no mesmo sentido que o fogo tem calor - acidente substancial. (teoria dos contrários). Horn, Christoph. Aspects of biology in Plotinus. Published to Oxford Scholarship Online: 2012, p. 11. Também, Gilson, op. cit., p. 116, refere que Agostinho se apropria da doutrina platônica, mas altera para adequar ao cristianismo (identificação da vida com Deus): "A tese platônica, que funda a substância da alma sob a indestrutibilidade da verdade sobre a qual ela se ergue, recebe disso uma significação inteiramente nova e vê abrirem-se diante de si possibilidades que Platão não teria suspeitado".
} 
Apoiada na experiência do 'eu penso', a certeza da imortalidade deixa de ser a conclusão de uma fórmula dialética pra tornar-se 0 ato pelo qual a vida se apreende como inseparável do pensamento no qual ela se aprende. Mas Agostinho ultrapassa também esse estágio: “como o 'eu penso' se apoiaria na Verdade suprema, finalmente, ele apoia a imortalidade da alma na necessidade de Deus. ${ }^{326}$

Ora, Deus é o ser em si mesmo e de nada participa, pois, caso contrário, não seria supremo, do que se segue necessariamente que a alma não possui o ser em si:

\begin{abstract}
A alma recebe dela seu ser: não pode receber de outra parte o que ela não possui por si mesma, senão de algo superior a si mesma; logo não há coisa alguma que retire da alma o ser, pois nenhuma outra coisa é contrária à verdade que outorga esse ser. Logo, a alma nunca deixa de ser. Mas obtém a sabedoria por conversão ao princípio de seu ser, e pode perdê-la por aversão, já que conversão e aversão se opõem. Mas, aquilo que recebe daquilo a que nada é contrário, não pode lhe ser retirado por causa alguma. Portanto, a alma não pode morrer. ${ }^{327}$
\end{abstract}

Assim, a alma, para ser determinada, deve receber seu ser e depende de uma fonte "originária e máxima", cujo princípio não admite contrário. Finalmente, a irredutibilidade do ser da alma, da natureza inteligível da alma, é garantida pelo princípio primeiro que estabiliza todas as essências participadas na essência suprema da qual depende. A alma que sabe que vive como primeira intuição do intelecto não é em si mesma; na verdade, é nesse Outro em que está apoiada sua essência. Trata-se da determinação participada do ser

\footnotetext{
${ }^{326}$ E. Gilson, Introduçao..., p. 116 Consultar Marion p. 95 cf. nota anterior - supra cit.

${ }^{327}$ De immortalitate animae XII, 19 Ex qua si habet animus idipsum quod est (non enim aliunde hoc habere potest, qui ex se non habet, nisi ab illa re quae illo ipso est animo praestantior), nulla res est qua id amittat, quia nulla res ei rei est contraria qua id habet; et propterea esse non desinit. Sapientiam vero, quia conversione habet ad id ex quo est, aversione illam potest amittere. Conversioni namque aversio contraria est. Illud vero quod ex eo habet cui nulla res est contraria, non est unde possit amittere. Non igitur potest interire.
} 
particular no Ser sem determinação e sem participação, cujo princípio não admite qualquer diminuição em sua essência, de modo que a alma, sendo partícipe do supremo Ser, enquanto substância inteligível e distinta do corpo, guarda absoluta impossibilidade de ser diminuída em essência em razão de qualquer contrário: não perde vida, não morre, justamente porque participa da essência da Vida.

Em Sobre as Duas Almas, o vício, contrário da virtude, em nada diminui o ser da alma, que continua sendo essencialmente verdadeira criatura. Não há vício que possa desqualificar o valor ontológico da alma na ordem hierárquica do ser, visto que o vício é meramente a virtude em grau diminuído. Insiste-se, a única determinação da alma é a vida, e participação da Vida, isto é, Deus: "Agora, voltemos nossas considerações para as virtudes, cujas luzes inteligíveis resplandecem a alma, segundo dizemos com pleno acordo da razão. Porquanto, chama-se vício aquela ausência de luz da virtude que não destrói a alma; apenas a obscurece" ${ }^{328}$.

\section{II,4 - Ontologia e ética. Alcance de duas defini ções}

\section{I ,4,1 A NATUREZA DA ALMA E A VI DA MORAL}

A primeira parte do tratado conduziu a polêmica para o domínio da interioridade, para dentro da alma. Fez a crítica do procedimento exteriorizante da gnose, discernindo as naturezas percebidas pela alma e conduzindo a questão para a existência e primado do espiritual ao corporal. Pelo cogito, chegou-se a conclusão indubitável de que a alma é uma substância incorporal que recolhe e conhece as criaturas ao seu redor, organizando-as segundo a

\footnotetext{
328 duab. an. VI, 6 Referamus nunc considerationem ad virtutem, cuius intellegibili luce splendere animum convenientissime dicimus. Porro ab hac luce virtutis defectus quidam non perimens animam, sed obscurans, vitium vocatur
} 
capacidade dialética de reconhecer a justa posição valorativa de cada ser.

Dito assim, dá a impressão de que o embate contra o maniqueu está resolvido, afinal, se toda a questão maniqueia fosse reduzida a ontologia, o problema já se resolveria na descoberta da substância incorporal. Mas Agostinho parece apenas ter preparado o terreno para o argumento decisivo contra a doutrina gnóstica das duas almas, o que indica que a questão maniqueia é mais ampla do que ontologia. De fato, há um dilema humano em torno da gnose que a ontologia platônica, aparentemente, não resolve satisfatoriamente, a saber, o pecado.

A crítica do procedimento maniqueu, no entanto, passa pela tradição platônica ${ }^{329}$, cuja teoria da alma permite manejar o movimento da alma em sentido interior. É possível pensar as relações internas das partes da alma, pois a interioridade habilita falar em "partes da alma", na medida em que the é útil para a compreensão das atividades da alma. Evidentemente, o termo "parte da alma", na teoria platônica, não tem nenhum sentido espacial ou temporal, visto que não se trata de partes substanciais. As partes da alma, como se verá, é uma distinção de ofício em Agostinho, ou seja, é a maneira de compreender a dinâmica interna que a alma mantém tanto com o corpo quanto com o intelecto. Com efeito, se guardados os resultados da primeira parte do tratado, facilmente se verificará que a "parte inferior" não pode ser uma substância separada da "parte superior".

A noção de pecado, no entanto, surge como novidade conceitual importante, pois, alheia ao neoplatonismo, ela reconduz a

\footnotetext{
${ }^{329}$ Consultar H. D. Saffrey. La théurgie chez les néoplatoniciens, In: Recherches sur le Néoplatonisme après Plotin. París, 1990, p. 168; Luc Brisson. Orphée, Pythagore et Platon. Le mythe qui établit cette lignée, In: Metaphysic und Religion. Leipzig, 2002, p. 423.
} 
problemática do mal para a relação das partes internas da alma incorporal. De fato, somente no final do tratado, Agostinho demonstra a relação confusa das partes da alma, conduzindo a definição de pecado como um movimento de imitação perversa: quando o superior imita o inferior.

Identificamos essa imitação como indício da natureza intelectual cindida, afastando-se de Plotino, para quem a alma superior partilhava da natureza divina (Intelecto perfeito). E como prólogo já indicava no tratamento do binômio miséria e misericórdia, ao final do tratado, Agostinho aprofunda a noção de pecado. Com efeito, o último movimento problematiza a questão da liberdade, pois o avanço conceitual importante que interiorizava a vontade como livre de qualquer determinação (nullo cogente) não será suficiente para responder satisfatoriamente o que o maniqueísmo fazia sem maiores problemas: uma contra vontade "misturada" à vontade. Agostinho reconhece um novo problema que nasce da dificuldade do hábito (consuetudo) herdado de pecar.

Trata-se do pecado como miséria, de origem misteriosa, que vem de dentro (interior) da alma e "milita contra si mesma". Trata-se de "um involuntário no seio do voluntário"330; uma dificuldade constatada no fato da experiência pessoal, que permitirá Alflat nomeá-la de "pecado involuntário"331, ou como J.L Marion refere: "tragédia da impossibilidade de querer querer"332. Talvez, o melhor termo é de Agostinho mesmo: pecado como "monstruosidade" 333 .

\footnotetext{
330 Ricoeur, P. O "pecado original": estudo de significação, In O conflito das interpretações. Ensaios de hermenêutica. Porto: Res Editora, 1989. p. 281.

${ }^{331}$ Consultar nossa introdução, II.1

332 J. L. Marion. Au Lieu de Soi. L'approche de saint Augustin. 2008, p. 235

333 cf. conf. VIII, 9,21
} 


\section{I ,4,2 PeCADo e UNI DADE DA ALMA}

Sabe-se que os vícios podem no máximo obscurecer a luminosidade da alma inteligível, afastando-a da sabedoria, mas a irredutibilidade da essência da alma é necessariamente salvaguardada, pois uma coisa é viver e outra coisa é o vício. Ou como dirá em seguida: "uma coisa é viver e, outra coisa, pecar" (aliud esse vivere, aliud peccare) ${ }^{334}$.

Para o maniqueu, vida e pecado estão misturados (commixtionis). Mais ainda, a vida, assim como a luz, está aprisionada no reino de trevas em razão de que a vida da alma fora tragicamente englobada pela matéria das Trevas na origem do pecado. No momento em que as trevas invadem a luz, a alma boa é envolvida pela alma má, formando um homem com dois gêneros de almas contrárias: uma, de vontade boa; a outra, de vontade pecaminosa.

Agostinho, ao lado do maniqueu e à diferença de Plotino, aceita que tanto o pecado como a vida possam ser encontrados no interior do homem, mas de maneira completamente distinta da gnose:

E nós poderíamos ver facilmente, depois de ter implorado pelo auxílio de Deus, que uma coisa é viver e outra coisa é pecar: ainda que uma vida de pecado, se comparada com uma vida justa, possa ser chamada de morte $(1 \mathrm{Tm} \mathrm{5,6)}$, uma e outra coisa [vida e pecado] podem ser encontrados no mesmo homem, que será, ao mesmo tempo, vivente e pecador. Mas, sendo vivo procede de Deus, e sendo pecador, não procede de Deus. ${ }^{335}$

\footnotetext{
334 duab. an. VII,9.

${ }^{335}$ duab. an. VII,9 Nam et nos fortasse implorato in auxilium Deo facile videre possemus, aliud esse vivere, aliud peccare: et quanquam vita in peccatis in comparatione iustae vitae mors appellata sit; utrumque tamen in homine uno posse
} 
É necessário precisar que o homem é ao mesmo tempo vivente e pecador. E para garantir que a vida de pecado não naturalize outra substância na alma, Agostinho traz os termos "justiça" e "pecado" para o mesmo plano conceitual da vida. A vida é simultaneamente justa e pecadora ${ }^{336}$. Evidentemente, que Agostinho neutraliza a substância do pecado, pois, o pecado, a rigor, não existe: é um dado vazio que, na linguagem cifrada do mito pode ser chamado de monstro ${ }^{337}$.

Resulta, pois, que "vida de pecado" é diferente de "pecado" e dizer que uma "coisa é vida e outra coisa é pecado" é dizer que uma coisa é inteligível, enquanto que a outra coisa é movimento da vontade para o não ser e, por isso, não é substância. O pecado como movimento da vontade contrário à justiça divina permite salvaguardar a unidade da alma e, ao mesmo tempo, não se furtar a incluir em sua doutrina essa absurdidade chamada de pecado.

Definir o homem como vivente, simultaneamente justo e pecador, não é questão menor, ainda mais quando se sabe que a vida de que se fala não é a vida apetitiva ou a vida sensível, mas a vida compreendida pelo intelecto, ou seja, é a própria alma intelectiva que é, ao mesmo tempo, vivente e pecadora. Adiante, ficará mais claro como essa simultaneidade requer um manejo conceitual que coloca o bispo para além da gnose e do platonismo. É suficiente por hora enfatizar que, por um lado, recusa-se que o pecado naturalize um outro em mim, uma alma má; por outro, ao conceder a presença do

inveniri, ut simul sit vivus atque peccator: sed quod vivus, ex Deo; quod peccator, non ex Deo. grifo nosso.

${ }^{336}$ A fórmula "simul iustus et peccator" terá grande fortuna no protestantismo luterano. Consultar McCue, James F. Simul iustus et peccator in Augustine, Aquinas, and Luther: Toward Putting the Debate. In Context J Am Acad Relig 1980 ${ }^{337}$ Em conf. VIII, Agostinho faz memoráveis as linhas que descreve a tormenta interior provocada pelo "monstro" da vontade. 
pecado na vida intelectiva, cria-se uma cisão na parte superior da alma que a tradição platônica dificilmente aceitaria.

Ainda que pecado e vida criem uma tensão no interior da vida humana, não se permite prescindir da unidade do homem ${ }^{338}$. E quando os textos bíblicos aparentemente disserem o contrário, necessitarão ser interpretados à luz dessas evidências alcançadas pela razão. A irredutibilidade da qualidade inteligível da alma, derivada da suma vida, possibilita eliminar a interpretação bíblica gnóstico-dualista como, por exemplo, em João 8, 47: "Quem é de Deus, ouve as palavras de Deus. Por isso, vós não ouvis porque não sois de Deus" ${ }^{339}$.

Ou ainda, na passagem do prólogo do Evangelho de J oão:

De que modo seriam verdadeiras as palavras do apóstolo no memorável prólogo do Evangelho: ‘Ele veio aos seus, e os seus não o receberam' (Ev. João 1,11 )? Pois como eram seus, se os seus não o receberam; ou como não eram seus por não tê-los recebido? A única

\footnotetext{
338 Sobre o tema da unidade da alma frente o dualismo psicológico maniqueu, consulte-se Ferraz, Marin. De La Psychologie De Saint Augustin. Deuxieme edition. Paris: Ernest Thorin, 1869. pp. 80-86 “Agostinho não se limita a estabelecer a simplicidade da alma. Ele demonstrou, ademais, de modo claro e peremptório, a absoluta indissolubilidade da unidade.", p. 80. Ferraz enfatiza a unidade da alma frente à diversidade do pecado na Trindade: "Se existe apenas uma alma para nossos pecados diversos... as faculdades (memória inteligência e vontade) não são três vidas mas uma única vida, não são três almas, mas uma única e mesma alma.". Para Ferraz, Agostinho retoma os tipos de alma em Aristóteles, vegetativa, sensitiva e racional, não para atribuir três almas diferentes, mas como propriedades que estão presentes, ao mesmo tempo, em uma única alma. Assim, Ferraz acerta quando relaciona as partes da alma com a dinâmica interior de ofício: "A alma humana é a seus olhos una por essência, ela é somente multipla por suas funções - in essentia simplex, in officiis multiplex - 'e a alma que rege o corpo animado não é distinta da alma que pensa', hoc corpus inspirata anima regit, eademque rationalis ( cf. De Trin. III,2,8)". Destarte, apesar do longo tempo que separa duab. an do De trin. não nos parece que Agostinho tenha alterado significantemente seu pensamento quanto as partes da alma. Agostinho mantém a distinção de ofício, tomando sempre o cuidado de dizer que 'as duas almas são a mesma alma'.

339 Vulgata: qui est ex Deo verba Dei audit propterea vos non auditis quia ex Deo non estis". Evidentemente, os maniqueus interpretavam o "vós não sois de Deus" como referente a alma má.
} 
maneira de entender isso sem contradição é que os homens pecadores, pelo fato de serem homens, pertencem a Deus; e por serem pecadores, pertencem ao diabo. Assim, quem diz: 'os seus não o receberam' considera a parte da natureza; aquele que diz: 'não eram de Deus' considera a vontade. O evangelista recomendava as obras de Deus ${ }^{340}$ e Cristo reprovava os pecados dos homens. ${ }^{341}$

O enunciado, "os seus não o receberam", deve ser interpretado sem dualismo, ou seja, o vocábulo "seus" deve significar as criaturas quanto à natureza, no entanto, quando o Cristo também diz que "vós não sois de Deus", trata-se do "mesmo homem", mas não mais quanto à "natureza" (irredutível como vimos). Permite-se dizer "algo não ser de Deus" somente nos modos da vontade, pois quanto à "vontade", Cristo de fato reprova o pecado.

Assim, Agostinho desloca o dualismo natural da gnose para a relação entre pecado do homem e justiça de Deus. O que a justiça de Deus rejeita não é uma natureza, mas um movimento da vontade, que é um não-ser chamado pecado. O pertencimento recolhido pelos pronomes possesivos presentes nessas passagens bíblicas expressa uma ambivalência de origem, pois quanto à natureza, somos homens originados por Deus; quanto à vontade pecaminosa, não. Disso, não se habilitará a divisão da alma em duas substâncias; no entanto, resulta necessário voltar para a noção de vontade para assegurar a absoluta unidade da natureza humana, mesmo diante do pecado.

Diante da presença de alma e vida no mesmo homem, fazse necessário compreender a vontade como aquilo que precede e

\footnotetext{
${ }^{340}$ ou seja, a natureza criada.

341 duab. an. VII,9 quomodo vera esset vox illa Apostoli, in ipso Evangelii memorabili principio, qua dictum est: In sua propria venit, et sui eum non receperunt. Unde sui, si non receperunt: aut unde ideo non sui, quia non receperunt: nisi quia homines peccatores, eo quod sunt homines, ad Deum; eo vero quod peccatores, ad diabolum pertinent? Hic ergo partem naturae tenuit qui ait: Sui eum non receperunt; ille vero voluntatis, qui ait: Non estis ex Deo. Evangelista enim Dei opera commendabat, Christus hominum peccata coercebat.
} 
possibilita o pecado: “certamente, o pecado não está em nenhum outro lugar senão na vontade" (nusquam scilicet nisi in voluntatem esse peccatum. duab. ab. X,12).

\section{I,4,3 COGI TO AMPLI ADO: SER, VIVER-QUERER, PENSAR.}

Lembre-se: o cogito é o argumento de existência que conjuga ser-vida-intelecção, sendo a vida compreendida pela parte superior da alma, a inteligência ou mente, logo alma como a priori dos sentidos: pensamento puro imediato e intuitivo ${ }^{342}$.

Nesse momento do tratado, o argumento é retomado ${ }^{343}$, pois o cogito que se utilizou para a primeira intuição inteligível ${ }^{344}$ agora é aplicado à relação entre pecado e a unidade da natureza da alma, o que necessariamente passará pela vontade:

É suficiente saber que eu vivo, saber que eu quero viver. E se o gênero humano concorda com isso, nossa vontade é tão conhecida quanto a nossa vida. E quando nós afirmamos saber essas coisas, não é preciso temer que alguém nos prove estarmos errados, pois, ninguém

342 cf. Gilson, Etienne. Études Sur Le Role De La Pensée Médiévale Dans La Formation Du Système Cartésien. Paris: J. Vrin, 1930. Chapitre II, Le cogito et la tradition augustienne: «saint Augustin, comme Descartes, s'appuie sur la certitude immédiate de la pensée pour en déduire la spiritualité de l'âme: Dans les deux doctrines, c'est par un acte de la pensée pure que l'âme se saisit comme existante; pour savoir ce qu'elle est, il lui suffira d'écarter d'elle même toutes les connaissances qu'elle acquiert du dehors au moyen sen»pp. 195-196. Consultar também nossa seção II,2, especialmente II,2,4.

343 cf. Ayres, Lewis. Augustine and the Trinity. Cambridge, UK; New York: Cambridge University Press, 2010. p. 135. Ayres reconhece que a triade ser-viverpensar assume diferentes funções. Ex. nos Solilóquios e no Contra Academicos o argumento serve ao contexto cético, enquanto que nas obras anti-maniquéias (ex. Duas almas e Livre arbítrio I) ele assume a função de revelar a unidade da vontade e intelecto do homem.

${ }^{344} \mathrm{cf}$. duab. an. 11,2 . 
pode estar errado acerca dessas coisas, a não ser que ele não viva e nada queira ${ }^{345}$.

Por "nossa vontade é tão conhecida quanto a nossa vida", Agostinho posiciona a noção de vontade necessariamente na inerência da vida, de modo que a tríade melhor se formula assim: ser, vida-vontade, intelecção. Percebe-se uma ampliação da própria noção de vida, pois, se por um lado a evidência da vida como ser inteligível garantiu-lhe a distinção do corpo, agora, o ser-que-sabeque-vive tem vontade. Agostinho dá um passo de alcance considerável, pois na primeira formulação da tríade neoplatônica o objetivo era estabelecer de partida a natureza incorporal da alma, e, portanto, possível receptora dos inteligíveis. Na retomada da tríade, além de substância incorporal, a alma é um ser intencional, pois será propriedade inequívoca da alma mover-se para as coisas ao seu redor (aliquid): "a vontade é conhecidíssima para nós: porque eu não saberia que quero, senão soubesse o que é a vontade nela mesma" 346 .

O cogito ampliado à vida volitiva, por assim dizer, assume aqui a função de desenhar uma natureza da alma que possibilita o aprendizado, por experiência, da distinção de "qualquer coisa" que exista, seja sensível ou inteligível ${ }^{347}$. Com isso, o pecado, como

345 duab. an. X,13 Liceat mihi me scire vivere, liceat mihi scire me velle vivere: in quae si consentit genus humanum, tam nobis cognita est voluntas nostra, quam vita. Neque cum istam scientiam profitemur, metuendum est ne nos quisquam falli posse convincat: hoc ipsum enim falli nemo potest, si aut non vivat, aut nihil velit.

${ }^{346}$ duab. an X.14. Non igitur nisi voluntate peccatur. Nobis autem voluntas nostra notissima est: neque enim scirem me velle, si quid sit voluntas ipsa nescirem. Definitur itaque isto modo: Voluntas est animi motus, cogente nullo, ad aliquid vel non amittendum, vel adipiscendum.

${ }^{347}$ cf. De Genesi contra manichaeos XII, 24. Consultar nossa introdução.

Lignum autem vitae plantatum in medio paradisi, sapientiam illam significat, qua oportet ut intellegat anima, in meditullio quodam rerum se esse ordinatam, ut quamvis subiectam sibi habeat omnem naturam corpoream, supra se tamen esse intellegat naturam Dei: et neque in dexteram declinet, sibi arrogando quod non est; neque ad sinistram, per neglegentiam contemnendo quod est: et hoc est lignum vitae plantatum in medio paradisi. De Genesi contra Manichaeos II,9,12. 
movimento da vontade, é a própria condição de existência do homem. Lembremos da condição humana exposta no comentário exegético ao Gênesis: “E no momento deste pecado (superbia) a pena que segue é que a alma deve aprender por experiência qual a diferença entre o bem que abandonou e o mal em que caiu" ${ }^{348}$. Ainda que caída, a alma permanece responsável por aprender o caminho de volta. Quer dizer que a vida orientada às coisas faz parte do caminho de retorno. E "aprender por experiência" só é possível quando a vontade cumpre o papel de ligação entre a alma e as coisas sensíveis ou inteligíveis (aliquid).

É possível que a necessidade de considerar a experiência do pecado exija a reformulação da tríade metafísica do "ser em si"349 aplicada à alma humana, de modo que a vontade seja inserida na tríade, não em substituição de algum elemento, mas como ampliação do segundo elemento, a vida. Tal inserção da vontade na tríade servida-intelecção tributa originalidade de Agostinho e, como se sabe, grandes alcances decorrerão no percurso da história da filosofia ${ }^{350}$.

A respeito da tríade, cuja vida se subsume na vontade, Du Roy a entende como um "novo cogito trinitário" referindo-se as Confissões XIII,11,12: “Quisera que os homens cogitassem dentro deles mesmos (in se ipsis) estas três coisas (...) E falo destas três:

348 "Et cum hoc eius peccatum poena fuerit consecuta, experiendo discit quid intersit inter bonum quod deseruit, et malum in quod cecidit" De Genesi contra Manichaeos II,9,12.

${ }^{349}$ Vide nossa descrição acerca da tríade ser-vida-intelecção em II,2

350 Hannah Arendt refere a Agostinho como o primeiro pensador da história da filosofia que elabora uma teoria da vontade. Cita o bispo nas Confissões, livro VIII, 8: "querer e poder não são o mesmo" para trazer a questão dessa íntima relação entre desejo e ação. Ou seja, mesmo estando a vontade em nosso poder, ou que a vontade esteja em lugar privilegiado nas faculdades humanas, tal vontade não é suficiente para poder fazer. Então, a lei racional está submetida à vontade, ao contrário do que se poderia pensar de um ser racional governado pela razão. Arendt afirma que é a vontade que move o espírito "o espírito não se move até que queira ser movido". Arendt, Hannah.A vida do espírito. Rio de Janeiro : Civilização Brasileira, 2009, p.350 ss 
ser, saber, querer (esse, nosse, velle). Pois sou, sei e quero: sou, querendo e sabendo e sei que sou e quero; quero ser e saber"351. Este "novo cogito" não se trataria mais do eu sou, eu vivo, eu penso, mas eu sou, eu penso e eu quero. Du Roy o entende como alteração do primeiro cogito (ser-viver-pensar), portanto, um remanescente do primeiro, fazendo-o coincidir com as três dimensões ontológicas da criatura. Para o estudioso, o "novo cogito" presente em Sobre as Duas Almas seria a preparação do "cogito trinitário" como “transposição da metafísica trinitária" ao plano da alma humana presente em obras posteriores. Cite-se: "esta transposição da metafísica trinitária ao plano das criaturas espirituais, nas obras anteriores às Confissões (i.e. contra Fortunatum), preparava diretamente o cogito trinitário" ${ }^{352}$. Neste trabalho, não será possível avançar sobre as obras posteriores de Agostinho para melhor compreender a tese de certa evolução de transposição trinitária no âmbito de criaturas. No entanto, ao analisar a tríade apenas no contexto aplicado ao combate ao maniqueísmo, a inserção da vontade como dimensão inerente a pura vida serve mais para elaborar um cogito ampliado que possibilita definir o pecado, do que um cogito novo análogo à Trindade.

Diante da exigência de considerar o pecado como fato da vida humana, Agostinho amplia a noção puramente metafísica, a priori, para uma dimensão de vida volitiva que permite caracterizar a alma como uma natureza essencialmente dinâmica e orientada à

${ }^{351}$ conf. XII,11,12 Vellem, ut haec tria cogitarent homines in se ipsis. Longe aliud sunt ista tria quam illa Trinitas, sed dico, ubi se exerceant et probent et sentiant, quam longe sunt. Dico autem haec tria: esse, nosse, velle. Sum enim et scio et volo: sum sciens et volens et scio esse me et velle et volo esse et scire.

352 'cette transposition de la métaphysique trinitaire au plan des créatures spirituelles, dans des ouvres certairnemeint antérieures aux Confessions (Contra Faustum, par exemple), préparait directemente le cogito trinitaire"Du Roy, op.cit., p. 432. 
relação ${ }^{353}$. É, pois, mais que uma reminiscência da tríade das pessoas divinas; na verdade, trata-se de pensar a liberdade como condição de partida da existência humana. Semelhantemente, Lossl comenta sobre o "argumento de autoconsciência" em A Verdadeira Religião (391):

Portanto, o argumento de auto consciência não é tanto um argumento epistemológico ou ontológico, mas está centrado no centro teológico-espiritual que tenta guiar a alma da absurdidade do pecado em direção a sua origem, no Uno, por via de uma lógica de conversão. ${ }^{354}$

Bem nota Lossl que a "lógica de conversão" ao Uno parte da "absurdidade do pecado". Ao que nos parece, a segunda parte dessa declaração tenta recolocar o "argumento de autoconsciência" em esfera ampliada a que referimos. Isso permite que o mistério do pecado, tomado como movimento ao não ser, seja ponto de passagem para atingir a completude inteligível do Uno (esse). A consciência de si como pecador prepara a conversão no terreno "spiritual theological".

353 Consultar Madec, G. Interiorité, intentionnalité. In: Petites Études Augustiniennes. Paris: Institut d'études augustiniennes, 1994. O autor propõe uma abordagem mais restrita da intencionalidade agostiniana pelo estudo semântico do texto conf. III,6,11 "Tu autem eras interior intimo meo et superior summo meo". Aponta a adjetivação do substantivo interius exigindo o segundo termo de comparação no caso ablativo. Com isso, o estudioso defende que o superlativo de comparação com o segundo termo no ablativo marca o aspecto de ultrapassagem (dépassement) do espírito humano na sua relação com Deus. A metáfora, pois, significa a tensão constitutiva do espírito humano (imanência) e o movimento de transcedência (Deus). Madec sugere que o cogito do $\S 72$ do vera relig. tem de fato aproximações possíveis com o ad esse de Husserl- quando compreendido como ultrapassamento de si. De fato, o cogito é um movimento à Deus, portanto, um movimento de transcedência à partir da imanência do espírito humano.

354 "The argument of self consciousness (vera relig. XXXIX.72. sq), is therefore not so much an epistemological or an ontological argument but lies in the centre of the spiritual theological which tries to guide these backing soul back from the absurdity of sin towards its origins in the One through a logic of conversion". LOSSL, Josef. The One (unum) - A guiding concept in De vera religione. In: Revue d'Etudes Augustinienne,40, 1944, p. 101. 
Sobrepõe-se, assim, a região espiritual ou moral à discussão do "argumento" que na modernidade serviu ao campo exclusivo da fortuna epistemológica, deslocando o cogito para a fundação da ciência, à guisa da admoestação à conversão da alma da nulidade do pecado para a completude da unidade de Deus. Do mesmo modo, a análise do tratado antimaniqueu de 392, portanto escrito quase em concomitância com a Verdadeira Religião, parece dar bases textuais razoáveis para confirmar a análise de Loss| ${ }^{355}$.

Resta caracterizar esses movimentos internos da alma, notadamente pela definição de pecado e vontade, a fim de explorar por via dedutiva os motivos profundos que cativaram o espírito do jovem retor.

\section{II ,4,4 Defi NI ÇÃo de Vontade}

Agostinho define a vontade como "um movimento da alma, isento de qualquer coação, tanto para não perder (non amittendo) quanto para alcançar qualquer coisa" ${ }^{356}$.

Pormenorizando os elementos da definição:

\footnotetext{
355 No entanto, questionamos se, na primeira metade de sua declaração, ao dizer que o argumento "is not so much" epistemológico ou ontológico, não estaria Lossl caindo na tentação de interpretar Agostinho ao gosto de um ontologismo contemporâneo, afã mesmo de afastamento do idealismo moderno? Cf. GILSON, E., The Future of Augustinian Metaphysics: "The two most dangerous temptations imperiling the integrity of its essence is Cartesian idealism and modern ontologism » p. 85. Note-se, Lossl não menciona o termo 'cogito' nenhuma vez! Consulte nossa nota em I.2.3; Quanto a nós, manteremos a indeterminação da conjunção aporética entre ontologia e moral (ou 'spiritual theological' como refere Lossl)

${ }^{356}$ duab. an X.14. Non igitur nisi voluntate peccatur. Nobis autem voluntas nostra notissima est: neque enim scirem me velle, si quid sit voluntas ipsa nescirem. Definitur itaque isto modo: Voluntas est animi motus, cogente nullo, ad aliquid vel non amittendum, vel adipiscendum
} 
(1) A vontade é motus animae, um movimento da alma, que é inerente à vida inteligível. Por conseguinte, a vontade partilha da própria substância incorporal da alma.

(2) É sem coação, nullo cogente. A alma possui autonomia de movimento. Ela move a si mesma e move o corpo, ou seja, é capaz de movimentar-se ativamente em direção às coisas e, fora dela mesma, nada determina seu movimento.

(3) A vontade é a única responsável pelo apego às coisas, ou seja, em possuindo algo determinado, não o perde (non amittendo). E, em não o possuindo, quer e busca possuílo (adipiscendum).

(4) Do que precede, resulta que sendo a vontade de natureza inteligível e responsável pelo movimento da alma, que rege o corpo, ela é o que dá estatuto moral de liberdade em poder afirmar ou negar sua vocação ontológica. Isto é, em situação intermediária entre sensíveis e inteligíveis (aliquid), pode ou se arrogar mais do que é, desejando ser da mesma substância divina, ou pode, por outro lado, se perder na fruição dos corpos.

A indeterminação da vontade, definida por sua condição de "movimento sem coação" (voluntas est motus animi cogente nullo. duab. an. $X, 14)$ é levada às últimas consequências das ações humanas. No limite, a vontade poderá negar a sua própria natureza, apesar de nunca perdê-la, afastando-se da suma convenientia ${ }^{357}$ da criação ao Criador. Nada, nem mesmo a percepção da natureza ordenada em beleza, proporção e racionalidade, poderá garantir o 
movimento humano à vida virtuosa. É uma ideia de liberdade associada à vontade tão penetrante que, possivelmente, não teria tido precedentes.

Entende-se porque Hannah Arendt $^{358}$ refere a Agostinho como o primeiro pensador da história da filosofia que elabora uma teoria da vontade. O hiponense romperia a ordem racional da filosofia greco-romana cuja lei racional submetia a vontade, pois, em sentido contrário, ele insistiria que, unicamente, a vontade tem a potência de mover todo o espírito: "o espírito não se move até que queira ser movido"359. Para Arendt, a vontade é uma faculdade diretora do saber e do perceber, pois é a única faculdade humana que não seria pensada em categorias causais. A vontade é a diretora da tríade: ser, querer e conhecer, pois não é possível dizer "não" para uma verdade revelada em termos racionais; nem é possível dizer "não" aos apetites intrínsecos a natureza humana, pois eles se dão automaticamente, sem que se escolha. Mas é somente na vontade que se teria o poder de dizer "não".

É importante marcar essa possibilidade da vontade de "dizer não" mais do que poder dizer sim, pois isso permite que a alma recuse o que é naturalmente harmônico (convenientia) ${ }^{360}$, em conformidade com a natureza (kata physin). Em suma, é sempre possível que a alma escolha pecar, a despeito de todo canto naturalmente harmonioso ou de toda beleza dos corpos ou, ainda, a despeito de qualquer contemplação imediata dos inteligíveis. Enfim, absolutamente nada pode determinar a vontade.

O leitor deve ter percebido o sabor estoico da discussão. Visitemos brevemente uma passagem de Sobre os fins dos bens e

\footnotetext{
${ }^{358}$ ARENDT, Hannah. A vida do espírito, 2009, p. 350.

359 idem, idem.

${ }^{360}$ de vera relig. $X L I, 77$.
} 
dos males III, em que Cícero testemunha os principais princípios da noção estoica acerca dos móbiles humanos, que, necessariamente, devem seguir o fluxo da razão/natureza. No diálogo, Cícero faz Catão eleger a filosofia do Pórtico como a única que soube dar a devida ênfase no princípio de que somente é bom o que é honroso, isto é, o belo moral, de modo que a virtude seja bem somente na medida em que concorde com a natureza ${ }^{361}$ : "De fato, caso não se tenha firme que só é bom o que for honroso, de modo algum pode-se provar que a vida feliz é produzida pela virtude; e, se assim for, não sei por que se deve dar atenção à filosofia". ${ }^{362}$

Sabe-se que, para filosofia do Pórtico, os fins de todos os bens e males convergem para a virtude, de modo que a filosofia estoica passa a fundamentar o télos racional desde os primeiros movimentos dos seres animais. Parte-se, pois, da análise dos primeiros movimentos de todos os seres, justificando no movimento inicial de todos os animais recém-nascidos uma tendência (hormé) à autopreservação e, consequentemente, o afastamento do que lhe é prejudicial:

"Pensam aqueles, cujo sistema eu aprovo", disse ele, "que o ser animado, assim que nasce (pois é daqui que se deve partir), torna-se caro a si próprio e se recomenda a si próprio com vistas a sua conservação e à de seu estado e a amar aquelas coisas que concorram à conservação desse estado". ${ }^{363}$

O ponto de partida para a hormé de autopreservação é o conceito de oikeiosis dos seres animados, que Cícero traduzia para o

\footnotetext{
${ }^{361}$ Cícero vai trazer nuances importantes da relação que o antigo estoicismo faz da virtude e natureza, como veremos adiante.

${ }^{362}$ Cícero, De Finibus III ,11; trad. LIMA, S.C., UNICAMP, 2009

363 Cícero, De finibus bonorum et malorum.,III,V,16. Tradução de Lima, S. C.. Oradores e filósofos no De finibus de Cícero. Tese de doutorado Ano de Obtenção: UNICAMP. 2009. Todas as citações do De Finibus serão de autoria de Limas,S.
} 
latim por conciliatio ou recommendatio. ${ }^{364}$ Trata-se de um processo, um movimento gradual por meio do qual a natureza do ser animado torna-o próprio a si mesmo. Primeiro, nos animais em geral, e, posteriormente no animal racional (conhecimento e ética). Qualquer animal que nasce, quer racional ou não, busca a conservação de si e segue o que lhe é próprio e característico (okeiosis). O homem racional escolherá necessariamente a virtude, segundo a orientação da razão.

A concórdia (oikeiosis), agora, exige o exercício da razão para a permanência da primeira inclinação. Cícero mantém o termo grego homologia, o que nos sugere ser relevante a decomposição do termo grego, que indica a função da inteligência do homem que deve viver em acordo com a razão ${ }^{365}$. A natureza específica do homem, animal racional, concilia a razão reflexiva e não mais a razão espontânea. A razão reflexiva deve seguir $o$ movimento de conformidade à natureza e ver a ordenação de suas ações, valorando ainda mais aquilo que já amara no período pré-racional, por catalepses. A reunião da conciliação do primeiro movimento e razão refletida é o que permite ao homem ver, ou verificar, se suas ações estão ordenadas segundo a natureza já percebidas no princípio. Portanto, a definição de dever nasce da importância de permanecer na razão, ou de se manter constante com o acordo instintivo proposto pela natureza desde a fase do recém-nascido.

\footnotetext{
364 Sobre a tradução do termo grego oikeiosis para o latim, conciliatio e recommendatio, consulte-se. Levy, Carlos, Cicero Academicus, p.386-387. Comenta sobre as razões da tradução do latim quando pareceria mais fácil simplesmente traduzir o equivalente à analogia grega como domesticus ou proprius. Levy sugere que a tradução ciceroniana é marcada pela influência da vida política romana que permeia todo o pensamento do autor. Assim, o primeiro termo, conciliatio é um termo tomado da retórica romana - o retor deve conciliar, promover o acordo e unidade da sua audiência. O segundo termo, recommendatio, sugere Levy, é uma metáfora do escritor que recomenda positivamente a recepção da carta.

365 A.A. Long, Carneades and the Stoic Telos.In: Phronesis, Vol. 12, No. 1 (1967), p. 61.
} 
Refere Cícero, por meio da voz de Catão: “...em seguida, ela é contínua, por fim, ela é constante e está em consenso com a natureza. É nessa escolha que, por primeiro, começa a estar contido e a ser entendido o que seja aquilo que pode, verdadeiramente, ser chamado de bem"366. O dever baseia-se em manter constante o que já estava estabelecido no primeiro movimento da percepção. A vida em conformidade com a natureza deve ser uma vida de deveres, ou seja, de ordenação das escolhas segundo o cálculo da razão e a disciplina do dever ${ }^{367}$.

Quando examinamos esse ambiente filosófico, cuja influência ainda se fazia notar nos círculos intelectuais da antiguidade $\operatorname{tardia}^{368}$, entende-se porque $\mathrm{H}$. Arendt tributa a Agostinho o título de primeiro filósofo da vontade. Certamente, afasta-se da concepção estoica de "vida de deveres", segundo a razão, cujo movimento voluntário da alma estava necessariamente rendido à força da natureza.

Atento as possíveis transformações do conceito de vontade em Agostinho, J. Wetzel nota um ponto de inflexão em Sobre as Duas Almas quando comparado ao Livre Arbítrio I. Separado por aproximadamente 4 anos, o diálogo da juventude teria sido escrito ainda sob forte influência da teoria moral estoica. Desse ponto de vista, como vimos, viver segundo a natureza (kata physin) é viver

\footnotetext{
${ }^{366}$ De fininbus... III,20. trad. LIMA, S.C., UNICAMP, 2009. Grifo nosso.

367 cf. Brehier, Emile. La théorie de la connaissance consiste précisément à faire rentrer dans le sensible le domaine de la certitude et de la science que Platon en avait soigneusement écarté. La vérité et la certitude sont dans les perceptions les plus communes, et elles n'exigent aucune qualité qui dépasse celles qui appartiennent à tout homme, même aux plus ignorants; la science, il est vrai, n'appartient qu'au sage; mais elle ne sort pas pour cela du sensible, et elle reste attachée à ces perceptions communes dont elle n'est que la systématisation. Histoire de la philosophie I. L'Antique et le Moyen âge. p. 300

368 Consultar O'Connell, Robert J. De libero arbitrio I: Stoicism Revisited. In: Augustinian Studies, vol 58 (1970); Wetzel, James. Augustine and the Limits of Virtue. 1992
} 
segundo a observação da ordem natural e racional. Para Wetzel, o conceito de vontade no diálogo ainda não teria se desvinculado das tintas da filosofia do Pórtico ${ }^{369}$, de modo que a livre vontade seria relativizada pela virtude que segue necessariamente a observação das coisas sensíveis naturais, prenhes de ordem. Assim, vontade e ordem da natureza seriam tomadas em unidade quase indistinta, de onde a capacidade cognitiva superior do homem seria plenamente capaz de perceber a ordem natural dos bens, ordenando e motivando a própria vontade ${ }^{370}$.

Vejamos um excerto do diálogo que conduz as conclusões do estudioso:

Ag: Portanto, se por nossa boa vontade amamos e abraçamos essa mesma boa vontade, preferindo-a a todas as outras coisas, cuja conservação não depende de nosso querer, a conseqüência será, como nos indica a razão, que nossa alma esteja dotada de todas aquelas virtudes cuja posse constitui precisamente a vida conforme a retidão e a honestidade. De onde se segue esta conclusão: todo aquele que quer viver conforme a retidão e a honestidade, se quiser pôr esse bem acima de todos os bens passageiros da vida, realiza conquista tão grande, com tanta facilidade que, para ela, o querer e o possuir serão um só e mesmo ato. ${ }^{371}$

\footnotetext{
369 “No Livre Arbitrio, Agostinho nos situa na ordem criada, cujos bens nos motivam em conformidade com a respectiva posição na cadeia de valores objetivos. Isso o leva a problemas, porque a motivação parece estar sob a determinação objetiva da ordem dos bens. Uma vez que tenhamos visto o mundo corretamente, nós nos encontramos sendo movidos e via apropriada, e nada restaria à volição fazer". idem, p. 93

370 cf. Wetzel, James. Augustine and the Limits of Virtue. Cambridge, 1992. "The source of Augustine's difficulty is his tendency to oppose the voluntary and the natural, making volition into a power to abstain from natural movement. When this power is not exercised, and we consent to natural movement, voluntary movement becomes indistinguishable from natural movement. In his discussion of virtue in book I of De Libero arbitrio his distinction between natural and voluntary movement is so underdeveloped that he cannot speak of us as acting in nature without implying that our actions are determined by natural forces of attraction". p.93.

371 lib. arb.(387) 1,13,29. Aug. - Hanc igitur voluntatem, si bona itidem voluntate diligamus atque amplectamur, rebusque omnibus quas retinere non quia volumus
} 
O pecado, dessa perspectiva, estaria circunscrito numa falha cognitiva da percepção da ordem hierárquica, portanto, um ponto cego da percepção ${ }^{372}$. Em sentido contrário, isto é, sob a análise racional dos bens, a vontade necessariamente seguiria a concórdia virtuosa da vida de retidão e de honestidade. Mas em Sobre as Duas Almas, segundo Wetzel, a vontade separa-se definitivamente da natureza. A marcação da liberdade é acentuada pelo não constrangimento da vontade. A percepção da ordem da natureza como pulsão de virtude não seria questão no tratado, justamente porque a vontade não depende dela para pecar ou deixar de pecar.

Evidentemente, o estudioso interpreta o termo "natureza" no sentido estoico de uma concórdia (oikeiosis/conciliatio) da ordem natural/racional dos sensíveis. Afirma que "as linhas de desenvolvimento vão contra o Livre Arbítrio, ainda que se chegue ao mesmo lugar":

Em Sobre as Duas Almas, [Agostinho] fala da vontade como se fosse capaz de motivar a nós mesmos independentemente do que nós percebemos ser de valor. (...) Volições são tão pouco determinadas pela ordem do mundo que elas cessam de ser motivadas em qualquer via inteligível. Agostinho flerta uma vez mais com a forma de volição como absoluto automovimento. E, a esse respeito, as linhas opostas dos dois trabalhos o colocam no mesmo lugar. ${ }^{373}$

possumus, anteponamus; consequenter illae virtutes, ut ratio docuit, animum nostrum incolent, quas habere idipsum est recte honesteque vivere. Ex quo conficitur ut quisquis recte honesteque vult vivere, si id se velle prae fugacibus bonis velit, assequatur tantam rem tanta facilitate, ut nihil aliud ei quam ipsum velle sit habere quod voluit. Tradução de Nair de Assis de Oliveira: ed. Paulus. 2011. grifo nosso.

372 Wetzel defende uma ruptura radical do conceito da voluntas entre livro I (388) e livro III (396). Esta ruptura, hiato entre o livro I e III, reorienta a investigação para as obras antimaniquéias entre 390-92, das quais afirma Peter Brown, Augustine of Hippo, 1967: "Augustine came to appreciate the sheer difficulty of achieving and ideal life", p. 148.

373 cf. Wetzel, Augustine and the Limits of Virtue., 1992, p. 93. 
De fato, parece correto, então, quando Wetzel afirma que as duas linhas de argumentação deixam Agostinho no "mesmo lugar", isto é, no afastamento da concepção maniqueia de uma origem natural do pecado. Wetzel, contudo, defende haver mais do que conjunção; de fato, busca enfatizar a evolução do conceito, a fim de marcar o ponto de ruptura da influência do estoicismo.

Para marcar o tom da livre vontade sem constrangimento (nullo cogente), o estudioso analisa o seguinte excerto do tratado: “Mas se essas almas [pecadoras] são boas, o que é a justiça? Se são más, o são por natureza ou pela vontade? Mas essas almas não podem de modo algum serem más por natureza" 374 e afirma "a fonte da dificuldade de Agostinho é sua tendência em opor o voluntário do natural, transformando a volição em um poder de abster do movimento natural" ${ }^{375}$.

Antes de assentir a análise do estudioso, é preciso notar que há duas maneiras de interpretar o termo "natureza". A primeira recupera o teor de um conceito de natureza em necessário acordo com a Razão, no sentido estoico. A segunda sugere meramente a natureza substancial, ou seja, a preocupação com a essência ou existência de algo. Wetzel sobrepõe as duas interpretações, o que, porventura, causará problemas.

É preciso, contudo, confirmar a avaliação de que o tratado de 392 representa um momento de transição entre o diálogo de 388 e as Confissões de 400. A cisão da vontade, notavelmente descrita no livro VIII das Confissões, deve passar pela radical internalização e indeterminação da vontade, tese forte de Sobre as Duas Almas. De fato, é importante que a cisão da vontade suceda um momento

\footnotetext{
374 duab. an XII, 17.

${ }^{375}$ Wetzel, op. cit., p. 93.
} 
voluntarista e interior dos móbiles humanos, pois a cisão não é um erro de cálculo da razão ou uma ignorância da ordem natural, mas uma deficiência da vontade em "querer querer". Mas isso Agostinho só pode descobrir devido ao enfretamento conceitual que rodeia a questão do pecado.

Dado que "não se peca senão pela vontade" (non igitur nisi voluntate peccatur. duab. an. X,12), e tendo sido exposto que a livre vontade é inerente à vida e à alma, resta examinar os alcances da definição no interior da doutrina maniqueia. Os argumentos que seguirão terão as definições de vontade e pecado como base da crítica ao dogma das duas almas.

Agostinho direciona sua crítica à origem da alma má, o que, consequentemente, fornecerá importante contribuição para a compreensão do pensamento de Agostinho acerca da falibilidade humana.

\section{I ,4,5 Defi NI ÇÃo de PECADo e A SUA ORI GeM}

\section{CF. DUAB. AN. XI,15 SS}

Agostinho propõe a seguinte definição: "pecado é a vontade de reter ou obter o que a justiça proíbe, da qual se é livre para se abster"376. Inteligentemente, faz a definição parecer demasiadamente óbvia e universal. Diz que é justamente isso que comumente "cantam os pastores, poetas, sábios, ou mesmo mercadores incultos" ${ }^{377}$. Mas nada é óbvio no arguto polemista. O escritor, retor e dialético, rompe com a gnose maniqueísta por um instrumental conceitual que, como

\footnotetext{
376 duab. an. XI,15 Ergo peccatum est voluntas retinendi vel consequendi quod iustitia vetat, et unde liberum est abstinere.

${ }^{377} \mathrm{cf}$. duab. an. XI, 15.
} 
vimos, não se encontrava nos manuais de filosofia moral de seu tempo. Ao dizer que os poetas e pastores cantam a justiça, Agostinho define o pecado pela recuperação da definição de vontade, que aqui aparece como ação de reter e obter - paralelos dos verbos da vontade que é livre para apegar-se ou possuir algo (amittendum aut adispicendum aliquid) -, acrescentada da justiça divina impressa universalmente em todos os homens, em todos os tempos, segundo o testemunho de seus poemas e cânticos. Pecar é voluntariamente recusar (dizer não!) o que a justiça divina veta. Dizer não a lei natural é opor-se a agir segunda a ordem da razão e mediante a parte intelectiva da alma; dizer não à razão dos cosmos e à evidência inteligível, o que seguramente representa importante afastamento da tradição da antiguidade clássica.

Desses dois conceitos, vontade e pecado, que são dados à mente de modo intuitivo e evidente, mas nada óbvio, resulta o ataque definitivo contra o dogma maniqueu.

\begin{abstract}
Agora, vejamos como essas coisas nos ajudarão. E é tão importante que toda a questão se encontre resolvida, que chego ao ponto de nada mais desejar. Com efeito, se alguém consultar as coisas secretas da sua consciência e ali ler a lei de Deus gravada na natureza, no interior da alma, onde essas leis são mais certas e precisas, ele deverá conceder que essas duas definições, de vontade e de pecado, são verdadeiras e deve condenar sem a menor hesitação toda a heresia dos maniqueus a partir de muito poucas e breves definições, no entanto invencíveis e definitivas. ${ }^{378}$
\end{abstract}

378 duab. an. 12.16. Age nunc, videamus quid nos haec adiuvarent. Plurimum omnino, ut nihil amplius desiderarem: totam quippe causam finirent. Nam quisquis secreta conscientiae suae legesque divinas penitus naturae inditas, apud animum intus, ubi expressiores certioresque sunt, consulens, has duas definitiones voluntatis atque peccati veras esse concedit, totam Manichaeorum haeresim paucissimis et brevissimis, sed plane invictissimis ratiunculis sine ulla cunctatione condemnat. 
Revisemos rapidamente a cosmologia maniqueia. Basicamente, apoia-se na cosmogonia que mescla duas naturezas contrárias $^{379}$ provindas uma do reino das Trevas e outra do Reino das Luzes. Tal "mistura" (commixtio) ao nível cósmico manteria certa correspondência com o mundo menor: a alma a qual os estudiosos da religião maniqueia denominam de "microcosmo"380, isto é, um pequeno mundo que imita o macrocosmo ${ }^{381}$ composto de uma mistura de Reinos antagônicos. Mistura de luzes e trevas que se mantêm ligadas sem contudo se fundirem, visto que ambas as almas preservam suas identidades substanciais inalteradas. $O$ homem estaria, assim, destinado a viver tanto num grande cosmos misturado quanto numa "interioridade corporalista" igualmente misturada, um microcosmo psíquico composto de trevas e luzes. Agostinho, então, aponta a incoerência desse microcosmo dualista, pois para a alma denominada substancialmente má se mesclar a alma boa, seria necessário que houvesse alguma vontade ${ }^{382}$ antes mesmo dessa

${ }^{379}$ cf. Ries, J.: “There was a first time, the initium, the time of the total separation of thetwo kingdoms, Light-Darkness. Following a struggle of Darkness against Light, a cosmogonic movement resulted in the mingling of the two substances. This is the mediumor middle time, the present universe". New Catholic Encyclopedia. Vol. 9. 2nd ed. Detroit: Gale, 2003. p106-115.

380 duab. an. XII,16 et ideo illud summum bonum, hoc vero summum malum esse praedicant: atque ista duo genera fuisse aliquando discreta, nunc esse commixta.

381 Sobre 'microcosmo' no gnosticismo, consulte-se Alfaric, P. L'evolution intelectuelle de Saint Augustin: "L'homme était destiné à concentrer et à perpétuer ici-bas le mélange de la Lumière et des Ténèbres. Aussi, résume-t-il, en sa personne l'ensemble de l'univers. II est un petit monde dans le grand. Comme le macrocosme, il associe deux natures contraires. Son corps procède du Démon tandis que son esprit vient de Dieu seul. Plus précisément, il possède deux âmes dont l'une est bonne, l'autre mauvaise par essence (...). Elle se trouve longuement développée dans le traité chinois de Chavannes et Pellio qui est en grande partie consacré à montrer que le microcosme est une imitation du macrocosme (Journ. Asiat., p. 523-527) » p. 117. grifo nosso.

${ }^{382}$ Cf. nossa análise da definição de vontade: Pormenorizando os elementos da definição: (1)A vontade é motus anime, um movimento da alma. Como vimos a vontade é inerente a vida inteligível, que é a própria alma de natureza substancial. Por conseguinte, a vontade partilha da própria substância incorporal da alma. (2) É sem coação, nullo cogente. A alma possui autonomia de movimento; é capaz de movimentar-se ativamente em direção as coisas. Fora dela mesma, nada determina seu movimento. (3) A vontade é a única responsável pelo apego às coisas, ou seja, em possuindo algo determinado, não o deixa escapar (non amittendo). $E$, em não o 
mistura original ter ocorrido, pois a vontade, como visto, é o princípio de movimento da alma.

Mas para o maniqueu, assim como temos nos testemunho de Fortunato, a mistura entre trevas e luz ocorre antes da vontade, o que cria uma noção de "pecado por constrangimento":

[Fortunato responde à Agostinho] A alma é constrangida (cogatur) a pecar pela natureza contrária (contraria natura). Você deseja que o pecado não tenha outra raiz senão unicamente no mal que se encontra em nós, embora seja fato (constet) que o Mal reine no universo inteiro, sem falar mesmo de nossos corpos (...). Mas a concupiscência do Mal não provém de nossos corpos: ela tira sua origem principal dessa natureza contrária da qual falei e que se encontra no mundo inteiro. ${ }^{383}$

Tal estado de alienação involuntária resulta na distinção radical entre origem da "contaminação" (coinquinatio) e o ato de pecado. Nesse caso, ou seja, em ter ocorrido uma mistura sem vontade, a natureza contrária corromperia a natureza boa por simples contato, assim como o fogo destrói o que toca, mas então, a natureza boa, que em última instância é o próprio Deus, seria uma vítima, passiva e inferior a essa natureza má, o que Agostinho evidentemente recusa.

$\mathrm{Na}$ origem do pecado, segundo o maniqueísmo, a alma é lançada no mundo e nesse momento não há livre arbítrio, o que

\footnotetext{
possuindo, quer e vai buscar possuí-lo (adipiscendum). (4) Sendo a vontade de natureza inteligível e responsável pelo movimento da alma, que rege o corpo, ela é o que dá estatuto moral de liberdade e constituição de si, pois em situação intermediária entre sensíveis e inteligíveis (aliquid), pode afirmar sua vocação original de discernir os valores essenciais de cada ser que a rodeia.

383 Augustinus, FORTUNATUS dixit: Hoc nos dicimus, quod a contraria natura anima cogatur delinquere: cui non vis esse radicem, nisi hoc tantum, quod in nobis malum versatur; cum constet exceptis nostris corporibus mala in omni mundo versari. (...) cum quando non est cupiditas mali ex nostris corporibus, ex principali illa contraria natura versatur in toto mundo. Acta contra Fortunatum Manichaeum , F. Decret and J. van Oort (eds.); traduction: F. Decret Brepols 2004:
} 
delimita a entrada do pecado no momento da queda da alma de luz no mundo corporal e, por isso, o pecado é identificado ao mundo. A origem do pecado, então, é o momento de lançamento de uma situação humana de mistura entre corpo e espírito a partir da queda da alma, provocada pela vontade cósmica das trevas em possuir as luzes, portanto, sem responsabilidade individual ${ }^{384}$.

Tentando explorar as contradições da metafísica gnóstica, Agostinho argumenta que, mesmo que se considere que a alma má tenha uma vontade, conforme definição "movimento da alma isento de coação", o que, então, explicaria o movimento do puro mal em direção ao puro bem? Afinal, o desejo de algo pressupõe algum conhecimento do desejado, de modo que se torna contraditório que o mal, antes mesmo da mistura original, contivesse algum bem nele mesmo ${ }^{385}$.

$E$, assim, eles afirmam que o primeiro é sumo bem, mas o último é sumo mal. Ademais, afirmam que em algum momento estes dois gêneros tinham sido separados, mas agora estão misturados (commixta). Eu não tinha ouvido acerca da origem e da causa daquela mistura, no entanto, já poderia perguntar naquele momento se aquele gênero mal de alma tinha qualquer vontade antes de ser misturado ao gênero de almas boas. $^{386}$

384 Decret Aspects Du Manichéisme Dans L'Afrique Romaine 2004, p.66: “II n'est nullelment question de libre arbitre: le monde matériel est péché et ce péché est connaturel à la chair. L'âme est plongée dans une situation qu'elle n'a pas provoqueée: elle, qui tire son origine de Dieu, ex aduentia dei parte (retr. 1,14,1) se trouve placée entre les adversaires. ». grifo nosso.

$385 \mathrm{cf}$. duab. an. XI 16. A vontade de corromper o bem pressuporia a presença de algum conhecimento de bem anterior a qualquer mistura, ao que Agostinho acusa de absurdo.

386 duab. an.XII,16 et ideo illud summum bonum, hoc vero summum malum esse praedicant: atque ista duo genera fuisse aliquando discreta, nunc esse commixta. Genus quidem commixtionis huius et causam nondum audieram: sed tamen iam quaerere poteram, utrum illud malum genus animarum, antequam bono misceretur, habuisset aliquam voluntatem. 
O esforço de reflexão se concentra na origem do pecado, pois, dado que não se peca senão pela vontade, qual teria sido a causa do pecado original? Qual a causa desse estado de mistura? Há dois caminhos possíveis para a gnose. Ou a causa da mistura foi um evento trágico de um pecado sem vontade, ou a vontade das trevas avançou sobre as luzes. Agostinho recusa a primeira, mostrando a impossibilidade lógica de pecar por constrangimento alheio, conforme as definições que foram aceitas anteriormente. $\mathrm{Na}$ segunda, relativiza-se, por assim dizer, a maldade do mal, pois não haveria nada de mais justo do que desejar o bem.

A reflexão acerca da origem do pecado levanta a questão da justiça divina e a danação do pecado. Não por acaso, o parágrafo 17 do tratado é dedicado a problematização do primeiro pecado sem vontade e com danação.

Portanto, para estabelecer que estas [almas más] não sejam em nada dignas de louvor - o que de fato me via obrigado a julgar pelos argumentos maniqueus -, eu questionaria se Deus condena (damnet) algumas almas ou nenhuma. Se nenhuma, não existe justiça com base no mérito como também não há nenhuma providência; e o mundo é governado mais pelo acaso do que pela razão: mais precisamente, não há governo porque não se pode confiar o governo ao acaso. ${ }^{387}$

Se a alma má existisse, como harmonizar estas duas noções: providência divina e justa punição de pecados? Todos devem concordar que Deus condena justamente algumas almas, pois de outra forma o governo se daria por mero acaso e não por providência. A condenação justa requer que a culpabilidade se

\footnotetext{
387 duab. an XII,17 Postremo, ut nihil horum laudandorum habeant illae animae, quae illorum rationibus habere coguntur, quaererem utrum aliquas an nullas animas Deus damnet. Si nullas, nullum meritorum iudicium est, nulla providentia et casu potius quam ratione mundus administratur, vel potius non administratur: non enim administratio casibus danda est.
} 
fundamente no movimento contrário à justiça. Tal movimento só é culpável se houver a livre vontade, pois seria injusto condenar alguma ação praticada sob uma coação de qualquer natureza. Logo, pecado e vontade, elementos circunscritos na alma, precedem a condenação:

Todos reconhecem que a condenação da alma má é justa e que injusto seria a condenação daquelas que não pecam. Admite-se, então, que aquelas almas que pecam são más. Ora, as almas das quais falam os maniqueus, conforme demonstrou a razão, não pecam. Por conseguinte, esta espécie estrangeira de alma má, apresentada pelos maniqueus, não existe. ${ }^{388}$

O silogismo visa o desmonte da doutrina gnóstica das duas almas pelas demonstrações de suas incoerências internas. Apoiada sobre as definições intuitivas de vontade e pecado anteriormente elaboradas, segue-se a demonstração da impossibilidade lógica da existência da natureza má a partir de termos comuns aos polemistas $^{389}$. Em suma, o argumento explora a incoerência interna: a alma má, em existindo, seria a única passível de condenação, pois peca quando se movimenta pela livre vontade em direção ao que a justiça divina proíbe. Mas, como demonstrado, a alma má, antes da mistura, não poderia ter voluntariamente se movimentado ao bem, pois nada há de mais justo do que querer o bem. Resulta que a alma má não pode existir (nullum est) sem negar as verdades intuitivas.

Note-se como os ingredientes do que viria a ser a doutrina do pecado original já estão todos aqui: eticidade, tragicidade, danação e penitência/arrependimento. O combate contra a polêmica das duas almas exigiu que o filósofo remontasse a história do pecado.

\footnotetext{
388 duab. an. XII, 17 At omnes fatentur, et malas animas iuste, et eas quae non peccaverunt, iniuste damnari: fatentur igitur eas malas esse quae peccant. Illae autem, sicut ratio docuit, non peccant. Animarum ergo malarum genus nescio quod extraneum, quod a Manichaeis inducitur, nullum est.

${ }^{389}$ cf. mor.1.2.3; c. ep. Man.5.3.4.
} 
E em busca de sua origem, percebendo que a doutrina gnóstica recusa que a origem do pecado seja um ato da vontade, Agostinho é levado a deslocar conceitos que inicialmente serviram-lhe para combater a naturalização corporalista da alma para o campo especulativo da gnose, cuja questão do pecado era associada a um evento "proto-histórico" que teria "misturado" substâncias de bem e mal antes mesmo da vontade individual.

O pecado como movimento da alma "para reter ou possuir o que a justiça proíbe" ganha dimensão universal. Mas em que medida Agostinho também recusaria o conceito gnóstico que preceituava um estado de mistura entre trevas e luz? Em outras palavras, como o primeiro pecado teria originado uma condição humana em que o pecado se ampliaria de um conceito voluntarista e jurídico para uma noção de pecado cuja origem remontasse a uma vontade compartilhada de um mal misteriosamente dejá-lá; em todos nós, portanto, supra individual?

A resposta esboça-se na parte final do tratado. Tendo negado a existência da alma má a partir de conceitos intuitivos e inequívocos, resta pensar, pelo instrumental neoplatônico, os novos problemas que são carregados por aceitar a agenda gnóstica. Tratase de pensar a possibilidade da alma intelectiva pecar. 


\section{I ,5 UNI DADE E FALI BI LI DADE DA ALMA}

A partir da teoria neoplatônica sobre a natureza da alma ${ }^{390}$, segue-se a reposição das definições da vontade e do pecado, a fim de combater o dualismo corporalista da gnose maniqueia no seu próprio campo conceitual. Com efeito, utiliza-se "partes da alma", segundo a tradição platônica, ${ }^{391}$ para colocar dificuldades ao maniqueísmo, o que dá a Agostinho oportunidade para importantes alterações da teoria recebida. O problema já foi de algum modo anunciado no decorrer de nossa exposição, mas sem pormenorizar o conflito que se criaria no interior da teoria neoplatônica sobre a alma, quando pensada a partir da vontade sem determinação acrescida da presença misteriosa do pecado.

Anuncia-se um tema tipicamente agostiniano, a cisão da vontade. Veremos a seguir um caso particular em que Agostinho lida diretamente com tal questão e será possível perceber o alcance dessa alteração quando no final do tratado o polemista retoma o binômio do prólogo, miséria e misericórdia. De fato, é esperado que o binômio retorne quando após descoberta da vontade sem constrangimento no interior do homem, também descobre-se uma presença perturbadora; ou melhor, uma doença espantosa (miris morbis) a que chamamos de pecado. Para compreender como o pecado se dá no interior dessa única alma, questiona-se: como explicar a capacidade do duplo assentimento em uma única alma?

\footnotetext{
${ }^{390}$ Consultar Ferwerda, R. Two Souls. Origen's and Augustine's Attitude toward the Two Souls Doctrine. Its Place in Greek and Christian, In: Philosophy Vigiliae Christianae Vol. 37, No. 4 1983. O estudioso refere-se a Enéadas II,9,5, em que Plotino, ao combater a gnose, considera a segunda alma como alma inferior ( $p$. 366). Também, cf. H. D. Saffrey. La théurgie chez les néoplatoniciens, In: Recherches sur le Néoplatonisme après Plotin. París, 1990, p. 168; Luc Brisson. Orphée, Pythagore et Platon. Le mythe qui établit cette lignée, In: Metaphysic und Religion. Leipzig, 2002, p. 423.

391 Possivelmente, Plotino segue Platão, que concedia a alma como indivisa nela mesma, mas dividida no corpo (como imagem e reflexão de si cf. Platão, Timeu 35 a). Consultar Fewerda, idem, idem.
} 
E se eu tivesse ensinado ou mesmo aprendido acerca do erro e delírio daqueles dois gêneros de almas, que razão poderia restar que considerasse os maniqueus [dignos] de serem ouvidos ou consultados sobre qualquer coisa? Ou eu deveria ter aprendido que a existência dos dois gêneros de almas resulta do fato de que, quando nós deliberamos, nosso assentimento se volta ora para o lado bom, ora para o mal? ${ }^{392}$

Segue-se a exposição do argumento enganoso da seita que hoje poderíamos chamar de "falácia causal non sequitur", ou seja, dado uma proposição em modus ponens ${ }^{393}$, o consequente não segue necessariamente seu antecedente, pois falta-lhe a consistência da relação causal. Poderíamos descrever pela seguinte notação:

- Se nós deliberamos e assentimos para o bem ou para o mal, existe uma alma boa e outra má em nós.

Isto é, nada garante que (non sequitur) a única possibilidade de explicar a dupla orientação do assentimento seja necessariamente a existência de duas almas. O que se segue necessariamente do pecado é a constatação da dupla orientação da vontade que, por sua vez, será signo (signum) de unidade do homem como composto de alma e corpo. É necessário fixar bem os fundamentos dos avanços alcançados pelo tratado. A deliberação para as coisas ditas más nada mais é do que movimento da vontade contrário à justiça divina. Ora, o pecado, sendo movimento e não natureza, é apenas mais um signo da unicidade humana, que é integral, única, não dicotomizada:

392 duab. an XIII,19 At si de duobus istis generibus animarum delirare illos et errare docuissem, aut certe ipse didicissem, quid remanere poterat, cur mihi iam de ulla re audiendi vel consulendi viderentur? An ut discerem hinc ostendi animarum duo esse genera, quod in deliberando nunc in malam partem, nunc in bonam nutat assensio?

${ }^{393}$ Se $\mathrm{P}$, então Q; $\mathrm{P}$, então Q. 
Por que isso [duplo assentimento] não seria mais sinal (signum) de uma alma única (unius animae) que, pela livre vontade, pode mover-se para este ou outro lado e voltar dessa ou daquela direção? Então, quando isso ocorre comigo, eu sinto que sou único, que considero ambos os lados e elijo um deles; embora, geralmente, um lado é prazeroso e outro adequado; e, colocados no meio entre eles, nós flutuamos. ${ }^{394}$

É importante notar que Agostinho não nega o antecedente da proposição, ou seja, não recusa que "quando deliberamos, assentimos para o bem ou para o mal ${ }^{395 ، .}$. Reconhece que a unidade do composto humano vive entre o prazeroso e o adequado (decet), criando um estado natural de "flutuação", pois a posição do homem "é no meio dessas coisas" (in médio quorum posit ${ }^{396}$ ). O mal, então, é desnaturalizado, pois torna-se apenas uma possibilidade da vontade.

Nada mais "natural", então, que carne e espírito conjuguem o ato de assentimento em flutuação: "Não se admira [dessa flutuação], pois que, sendo constituídos de tal forma, sejamos influenciados tanto pelo prazer, por via corporal (per voluptate carnem), quanto pela retidão, por via espiritual (per spiritum honestate) ${ }^{397}$. Esta "posição intermediária" da alma tem um sentido forte de constituição (esse constitutum) humana, pois a mistura entre substâncias polares é ressignificada como unidade do composto corpo e alma ${ }^{398}$; condicionante da dupla orientação do espírito.

\footnotetext{
394 duab.an. XIII,19 Cur non magis hoc signum est unius animae, quae libera illa voluntate huc et huc ferri, hinc atque hinc referri potest? Nam mihi cum accidit, unum me esse sentio utrumque considerantem, alterutrum eligentem: sed plerumque illud libet, hoc decet, quorum nos in medio positi fluctuamus.

${ }^{395}$ Evidentemente, há um jogo retórico em assumir o termo "mal" sem natureza.

${ }^{396}$ cf. Gn. C. man. II,9,12 . Consultar nossa introdução.

397 duab.an. XIII, 19 Nec mirum: ita enim nunc constituti sumus, ut et per carnem voluptate affici, et per spiritum honestate possimus.

${ }^{398}$ Consultar nossa análise de mor. I, 4,6 2.
} 
Em seguida, Agostinho recupera os termos, reconhecidamente platônicos, que deixara momentaneamente em suspensão (sescedat paulisper ${ }^{399}$ ). Os termos “inteligíveis" e "sensíveis" são retomados para esclarecer que, no âmbito indubitável (cataléptico) da unidade da alma inteligível, a dupla orientação do espírito se dá quando naturezas inferiores e superiores ou também conhecidas como sensíveis e inteligíveis são apresentadas (affectum) ao espírito.

Avança-se numa distinção de plano conceitual importante: "inferiores" e "superiores" já não são sobrepostos a bem e mal. Inferior não é sinônimo de mal, pois das coisa baixas não se retira a dignidade, pois é dito que se trata de "dois gêneros de coisas boas" (duo genera bonarum rerum) no interior de uma mesma natureza inteligível. Uma mesma alma, portanto, possui partes diversas (unam animam...ex diversis partibus); precisamente, duas partes polares: "inferior e superior"; ou ainda, conforme indicado no início do tratado, parte "inteligível/sensível" ou "interior/exterior":

Pois seria muito melhor e mais fácil entender que se trata de dois gêneros de coisas boas, nenhum deles alheio a Deus, seu criador, e que uma única alma está afetada $^{400}$ pelas diversas partes (unam animam ex diversis afficere partibus), inferior e superior, o que pode corretamente ser dito exterior e interior. Estes são os dois gêneros do qual a pouco tratamos pelos nomes de sensíveis e inteligíveis, aos quais chamamos mais prontamente e familiarmente de carnais e espirituais. ${ }^{401}$

\footnotetext{
399 duab. an. X, 13 Secedat paulisper illa intellegibilium sensibiliumque distinctio (seja suspensa momentaneamente aquela distinção entre inteligíveis e sensíveis).

400 R. Teske traduz "aninam afficere" por "to be influenced". Preferimos o verbo afetar, pois conota a alteração da alma por percepção, segundo os modos de compreensão das coisas. Teske, 2006, p. 131

${ }^{401}$ duab. an. XIII,19 Possumus enim melius et multo expeditius intellegere duo genera bonarum rerum, quorum tamen neutrum ab auctore Deo sit alienum, unam animam ex diversis afficere partibus, inferiore ac superiore, vel quod recte ita dici
} 
O vocabulário retirado da tradição filosófica permite expressar o "exterior" como um gênero distinto do "interior" sem naturalizar as partes da alma. Assim, da existência de dois gêneros de coisas boas em "uma mesma natureza", Agostinho pode elevar a alma ao estatuto de interioridade ao mesmo tempo em que a situa na fronteira da exterioridade e, assim, reponder a questão da comunicação com os corpos como atividade volitiva essencial da alma ${ }^{402}$, garantindo o primado do inteligível sobre as representações sensíveis, bem como a dignidade dessa última como "gênero de coisa boa".

Destarte, a parte da alma que se liga ao exterior é um gênero, mas sem substância, o que pode soar de início um tanto curioso. A fim de entender melhor esse quadro da natureza da alma em Agostinho e não cair em um dualismo ingênuo ${ }^{403}$, tomemos, ainda que brevemente, alguns antecedentes da discussão neoplatônica.

\section{II,5,1 DOIS GÊNEROS DE COISAS BOAS, INFERIOR E SUPERIOR, NA MESMA ALMA}

Propomos uma breve revisão da teoria sobre a alma em Plotino, a fim de verificar as dificuldades que Agostinho teria ao inserir o pecado como um dos elementos basilares de sua doutrina.

potest, exteriore atque interiore. Ista sunt duo genera, quae sensibilium et intellegibilium nomine paulo ante tractavimus, quae carnalia et spiritalia libentius et familiarius nos vocamus.

402 cf. Gn. c. man. $11,9,12$

403 De fato, nas Retratações, Agostinho retoma o tratado duab. an. para se defender de tal acusação e reponde a questão expressamente nos termos da doutrina do pecado original. 
Possivelmente, emprestam-se os termos da metafísica platônica ${ }^{404}$ em esforço de compreensão da relação entre terceira hipóstase e o corpo. Vejamos um excerto em que Plotino interpreta a alegoria da caverna de Platão:

Assim é dito com razão que a alma se encontra em uma tumba e em uma caverna. Mas, apesar disso, retorna para o alto, convertendo-se ao ato do intelecto (...), e pela memória contempla de uma nova maneira a essência das coisas. Porque temos que convir que as almas têm necessariamente uma dupla vida (amphibioi): pois, por um lado, vivem em parte a vida inteligível; por outro, vivem também em parte a vida deste mundo. ${ }^{405}$

Para Plotino, portanto, as almas humanas vivem simultaneamente no mundo sensível e no mundo inteligível, existindo por necessidade uma parte da alma caída em contato com os sensíveis e outra não caída em contato com os inteligíveis. ${ }^{406} \mathrm{~A}$ vida assume, assim, além do aspecto metafísico, uma concepção orgânica ${ }^{407}$, isto é, mantém necessariamente uma natureza "anfíbia" (dupla vida): por um lado, a vida está necessariamente contida no Intelecto, a priori dos sentidos corporais; por outro, pela parte

404 Agostinho teria tido contato com as Enéadas (tratados 4.2, 4.3 e 7.7) cf. O'DALY, Gerard J. P. Augustine's Philosophy of Mind, 1987. pp. 10-13.

${ }^{405}$ Enéadas IV,8[6]4. Que el alma se halla en una tumba y en una caverna, pero que, vuelta hacia el pensamiento, se libera ya de esos lazos y emprende la marcha hacia arriba cuando parte de la reminiscencia para llegar a contemplar los seres.... Por lo que hemos de convenir que las almas tienen necesariamente una doble vida ('amphibioi'): pues, por un lado, viven en parte la vida inteligible, y por otro viven también en parte la vida de este mundo. Plotino. Enéadas: libros III y IV. Gredos. 1985. Tradução em português seguiu-se de alterações pelo cotejo com a tradução inglesa de Stephen MacKenna. The Enneads, 1992. grifo nosso.

406 cf. Horn,2008. Le concept de vie chez Plotin. «Cette partie demeure toujours dans la réalité intelligible. Ainsi, sommes-nous arrivés à la conception de différentes niveaux ou degrés d'existence humaine »p. 108.

J ohn Dillon corrobora ao referir que em Enéadas IV 8, “In Enn. IV 8 Plotinus makes clear that, though such a fall may be a misfortune for the individual soul, the process was necessary for the completion of the universe, and is thus ultimately a good thing. Also, the World-Soul, and the highest part of the individual soul, cannot be said to descend in the strong sense". Plotinus at Work on Platonism. In: Greece \& Rome, Second Series, Vol. 39, No. 2 (Oct., 1992), pp. 189-204. p. 200.

407 cf. Horn, C., op. cit., p. 97 ss. Consultar Enéadas III,8[30],8 
inferior da alma, a vida da alma mantém a comunicação com os corpos. No entanto, as duas partes permanecem como parte de uma única hipóstase, a alma, mantendo no interior da terceira hipóstase certo grau de ambivalência ${ }^{408}$.

De fato, dessa aporia plotiniana, Jâmblico poderá dizer não ser possível verificar se Plotino sustenta, a diferença de Numénio, uma teoria da alma em que sua parte superior permaneça indistinta dos deuses e do Intelecto:

E eles localizam mesmo na alma individual o mundo inteligível, e os deuses e demônios, e o Bem, e todas as coisas superiores a ele.(...). A doutrina oposta a essa, entretanto, separa a Alma na medida em que ela tanto sucede quanto segue o Intelecto, representando um nível distinto do ser, e o aspecto disto que é dotado com intelecto é explicado como ser conectado com o intelecto, certamente, mas também como subsistindo independentemente nele próprio ${ }^{409}$

\footnotetext{
408 Sobre o tema da alma em Plotino, consultar Lavaud, Laurent, "La diánoia médiatrice entre le sensible et I'intelligible". In: Études platoniciennes III: L'âme amphibie - Études sur l'âme selon Plotin. 2006, pp. 29-55

409 Jâmblico, em De Anima 1,6-7: traduzido de John F. Finamore, and John M Dillon. Iamblichus De Anima. Leiden; Boston, MA: Brill, 2002. Jâmblico problematiza o otimismo de Plotino, para quem a alma intelectiva não teria se apartado do Intelecto divino. Passagem semelhante poderá ser encontrada em De Mysteris II,11,16-56. L. Brisson traduz e interpreta a passagem nos seguintes termos: "Jamblique réfute la thèse de Plotin suivant laquelle une partie supérieure de l'âme demeure dans les intelligibles. Pour Jamblique, l'âme s'unit complètement au corps: c'est la position aristotélicienne, qui entraîne une autre: le salut de l'âme doit nécessairement venir d'ailleurs, et notamment de la théurgie comme il l'explique dans ces lignes: Ce n'est pas par la pensée que les théurges s'unissent aux dieux, sinon qu'est-ce qui empêcherait ceux qui pratiquent la philosophie théorique d'obtenir l'union théurgique avec les dieux? En vérité, il n'en est pas ainsi, mais c'est l'accomplissement religieux des actions ineffables et qui dépassent toute notre intellection, et le pouvoir des symboles inexprimables et compris seulement des dieux, qui procurent l'union théurgique. C'est pourquoi ce n'est pas par l'opération de l'intellect que nous accomplissons ces actions, sinon elles seraient d'ordre intellectif et vendraient de nous La vérité ne peut être atteinte qu'au terme d'une révélation que dispensent les dieux eux-mêmes qui apportent ainsi un remède à la faiblesse humaine" Luc Brisson. Orphée, Pythagore et Platon. Le mythe qui établit cette lignée, en Metaphysic und Religion. Leipzig, 2002, p. 422-423. Na mesma linha de intrepretação, consulte-se também H. D. Saffrey. La théurgie chez
} 
Jâmblico critica a teoria de que alguma parte da alma pudesse manter alguma íntima relação com o Intelecto ao ponto dela mesma não se distinguir da própria substância divina. Em tal doutrina, a parte superior da alma, não caída, manteria contato permanente com a hipóstase superior, o Intelecto, enquanto que a parte inferior permaneceria atada aos sentidos ${ }^{410}$. Com isso, Jâmblico pretende manter a independência da alma como substância "distinta" do divino ${ }^{411}$. Para esse, não se admite que a alma individual contenha em si os inteligíveis, visto que, sendo a parte superior da alma ligada ao Intelecto, "a alma não difere em nenhum modo do intelecto e dos deuses, e nem da classe superior de ser, pelo menos em respeito a esta substância em geral". (Jâmblico, De Anima I,6).

Postula-se, assim, que a alma subsista distinta dos seres divinos superiores, situando-a definitivamente em termo mediano, o que "separa a alma de todas as classes superiores de ser, e aponta como a definição particular de sua essência: no modo que é o termo mediano dos seres divisíveis e indivisíveis, corpóreo e incorpóreo" ${ }^{412}$

les néoplatoniciens, In: Recherches sur le Néoplatonisme après Plotin. París, 1990, p. 168.

${ }^{410}$ Ver também Jâmblico, Tim. Fr. 87.

411 cf Dillon e Finamore. Iamblichus De Anima, p.89: "The position which he criticizes involves making no essential distinction between the soul and the levels of being superior to it - in particular the various levels of the intellectual real - nor yet between various types of soul". Consultar também Carlos Steel in Encyclopedia of Philosophy, verbete "neoplatonism" pp. 546-557. Sobre a distinção entre o intelecto e a parte superior da alma em Jâmblico, Carlos Steel afirma: "Within the intelligible realm, he further distinguishes the purely intelligible from the intellectual level. And whereas Porphyry, following Plotinus, identified the supreme part of the soul with the intellect, Iamblichus insists that the soul is a separate ontological entity, intermediate between the intelligible and the sensible and therefore lower than intellect. Situated between the soul and the intellectual gods, the classes of demons, angels, and heroes have an important mediating function. All this announces a tendency that will become dominant in the later development of the school". grifo nosso.

412 Jâmblico, De Anima I,7. grifo nosso. W. Hankey comenta que Jâmblico, em oposição à noção de conhecimento de si imediato proposto na filosofia tanto de Plotino quanto de Agostinho, inaugura um sistema de mediação entre a alma, os sensíveis e as ideias divinas: "more and more the Latins thought in terms of a system of total mediation. They [filosofia medieval] agreed with lamblichus that the 
Nosso objetivo em resgatar esses antecedentes neoplatônicos, obviamente, não visa resolver qualquer polêmica no interior do neoplatonismo. Nosso intuito é apenas partir de um solo comum com o qual Agostinho estaria familiarizado, apropriando o vocabulário e transformando o conteúdo metafísico platônico segundo seu interesse. O que nos importa nessa breve referência às partes da alma é notar como tal divisão no interior da unidade da terceira hipóstase nos afasta de certas leituras que pressupõem um neoplatonismo tout court em Agostinho. Mais do que resolver as ambivalências, trata-se de perceber o esforço de incluir a falibilidade humana no modelo da conversão plotiniana.

\section{II,5,2 APROPRIAÇÃo dAS “PARTES DA ALMA" POR} Agosti Nho.

De fato, parece muito plausível que Agostinho tenha em mente a metafísica plotiniana quando insere esta divisão "relativa" da

immediate access of the Augustinian and Plotinian soul to the divine ideas did not provide an adequate account of human experience... Placed, as humans are, at the middle, and not being able to return immediately, if we are to return to the absolute source at all, we must tum in relation to the whole, including the material. " HANKEY, Wayne. Between and Beyond Augustine and Descartes: More than a Source of the Self; In: Augustinian Studies 32: I (2001), p. 86. O autor identifica a parte superior da alma como "local" da imediação e intuição do cogito; no entanto, Agostinho, à diferença de Plotino, reconhece, pela própria experiência humana, a clivagem no interior da parte superior da alma como fundo de possibilidade para desenvolver sua noção volitiva de pecado. Assim, a noção de pecado parece ser a lenta adequação da experiência, pela força do hábito, que Agostinho identifica como a condição do homem criado em situação intermediária e cuja queda ocasionou a situação de falibilidade da da alma, pois o pecado original vai intensificar a noção de um hábito dado para além da individualidade. Dessa dificuldade, o pensamento de Agostinho torna-se necessariamente cristológico, no sentido exato da mediação, mas em duplo sentido: a) pela iluminação do intelecto; b) pelo verbo encarnado contemplado na história. De fato, no sentido primeiro, o cogito é imediato ao intelecto, no entanto a participação do antecedente, a Verdade, é a própria garantia da intuição verdadeira (representação cataléptica inteligível). O cogito agostiniano, desde seu ponto de partida, é um argumento dependente, alter-nomo por excelência, cuja identidade necessariamente está definida alhures de si. Nesse sentido é um cogito fraturado, logo, carente de mediação, visto o hábito dessa vida impossibilita o retorno à plena unidade com Deus. 
alma no contexto do quadro conceitual da vontade e do pecado - dizse "relativa", porque esta divisão entre partes superior e inferior presente em Plotino, e adotada por Agostinho, não contraria o que, com muito esforço, ambos os pensadores se esforçam a construir, a saber, a unidade da alma inteligível que por natureza permanece indivisa-. Aporeticamente, contudo, a alma é ao mesmo tempo una e dividida. É una em natureza, e múltipla no ofício da comunicação com as substâncias ${ }^{413}$.

Mas a aporia não se dá ingenuamente. A crítica de Jâmblico à Plotino pode nos ajudar a entender a discussão neoplatônica da natural divindade da alma, bem como a posição agostiniana quanto a falibilidade humana; isto é, a possibilidade de uma mesma alma inteligível pecar e sofrer ${ }^{414}$. Eis a questão que se coloca a partir de Plotino, Enéadas 1,1[53],10: se a alma superior permanece intimamente vinculada ao Intelecto, haveria possibilidade para pensar o vício como um movimento engendrado no interior da alma racional?

\begin{abstract}
Mas, se nós somos a alma e nós experimentamos essas afecções, a elas estaria experimentando a alma e, por sua vez, ele fará o que fazemos. Ora, dissemos que o composto também é nosso, principalmente quando ainda não estamos separados: pois nós dizemos experimentar aquilo que experimenta nosso corpo. Portanto, o 'nós' é um duplo: um que inclui a besta e outro que já está acima disso; e a besta vivificada é o corpo. Mas o homem verdadeiro é outro, é o que está purificado das afecções e é possuidor das virtudes da intelecção, que certamente se assentam na própria
\end{abstract}

\footnotetext{
413 Conforme Ferraz observa em conf.VII,10 Agostinho reconhece dois gêneros de coisas, em graus distintos, ambos derivados de Deus, sendo um a parte superior, e outro a parte inferior de nossa alma, (cf. conf. VII, 10). « L'âme humaine, -il le dit en propres termes et avec une précision peu commune, - l'âme humaine est à ses yeux une par son essence; elle n'est multiple que par ses fonctions, - in essentia simplex, in offlciis multiplex, - et l'âme qui régit le corps n'est pas distincte de l'âme qui pense » Ferraz, De la psicologie de Saint Augustin. p. 84 ( cf. De Trin. III,2,8; X, 11; conf. X,7).

414 cf. Armstrong, Arthur Hilary Augustine and christian platonism. In Villanova University. Lecture 1966.
} 
alma que está se separando, separando-se e separada mesmo estando aqui; pois quando ela se afasta completamente, a que é iluminada por ela sai acompanhando-a. Entretanto, as virtudes que não se originam da sabedoria, mas de hábitos e exercícios, são do composto; dele, pois são os vícios, porque invejas, ciúmes e piedade também o são. $E$ as amizades, de quem são? Algumas, dele, outras, do homem interior. ${ }^{415}$

Já vimos, a alma possui uma dupla vida (alma anfíbia): sensitiva e intelectiva, o que é retomado nesse trecho quando Plotino diz que “o 'nós' é um duplo". Importa, agora, chamar a atenção para a associação entre a origem da virtude e do vício com a teoria das partes da alma. Diz que as virtudes se originam de dois modos: da intelecção e do hábito. Quanto à virtude da intelecção, a alma faz o caminho do afastamento gradativo dos corpos; enquanto que a virtude do hábito, as que não se originam na sabedoria, dependem do composto, alma e corpo. Os vícios também são da ordem do composto, alma e corpo, e o são na medida em que alma não se afasta do corpo.

Coerentemente com os preceitos platônicos do Primeiro Alcibíades acerca do homem, Plotino entende esse homem viciado, não purificado, como um não-homem, ou um não "homem verdadeiro"416. Trata-se de um “outro" homem que não fez a

415 Plotino, Enéadas I,1[53],10 In: BARACAT, J osé Carlos, Júnior. Plotino, Enéadas I,II e III; Porfírio, Vida de Plotino. Introdução, tradução e notas. UNICAMP, 2006.

416 Sobre a "complexidade" da antropologia plotiniana, consulte-se J. Pepin (Idées grecs... pp. 95-101). O autor busca a fortuna da antropologia do Primeiro Alcibiades (130 a-c) de Platão. Em primeiro momento, a complexidade da antropologia plotiniana - composto de corpo e alma, partes da alma em superior e inferior, verdadeiro homem, homem eterno e engendrado, homem lá de cima e aqui de baixo- parece se distanciar da ideia central do Primeiro Alcibíades, visto que "o homem todo inteiro é definido pela sua alma" (p.79), ou nas próprias palavras de Platão: "Conhecer-se a si mesmo é o fim do homem, que consiste em conhecerse a si mesmo enquanto alma" (...) "O homem é a alma" (Alcib. 130c-132b). Pepin conclui que a complexidade da antropologia de Plotino não faz senão enriquecer “infiniment l'anthropologie de I. ${ }^{\text {er }}$ Alcibiades, ces différentes traits montrent que c'es d'elle qui'l part". p.100. 
separação do que é comum às bestas. Portanto, o que em nós comete vício está alienado da intelecção, que é pura e diz respeito à parte inferior da alma, pelo que respondemos a questão anterior negativamente. Para Plotino, alma superior não peca, justamente, porque permanece como parte não caída, unida ao Intelecto.

Mas, se a opinião e o raciocínio são da alma, como ela é impecável? Pois falaz é a opinião e muitos males são praticados por causa dela. Os males são praticados quando somos vencidos pelo pior em nós - pois nós somos multiplicidade - seja pelo desejo, seja pela raiva, seja por imagem do mal; porém o chamado raciocínio sobre coisas falsas é uma imaginação que não aguardou o juízo da parte raciocinante, mas praticamos o mal obedecendo às partes inferiores, assim como no caso da sensação, onde, antes de julgar com a parte raciocinante, acontece à sensação comum ver coisas falsas. $E$ o intelecto ou tocou ou não, de modo que é impecável. ${ }^{417}$

${ }^{417}$ Plotino. Enéadas I,1[53],9. Tradução Baracat J r., J. C. grifo nosso. Sobre o tema da alma em Plotino, consultar Lavaud, Laurent, "La diánoia médiatrice entre le sensible et l'intelligible". In: Études platoniciennes III: L'âme amphibie - Études sur l'âme selon Plotin. 2006, pp. 29-55; especialmente o cap. V. La question du jugement faux (cf. Enn. I, 1 (53), 9). Somos gratos ao prof. Carlos Eduardo pela aula ministrada na FFLCH-DF-USP, que nos indicou o texto de Plotino em análise comparativa ao div. qu., questão 46, De ideis, em que Agostinho afirma que somente a parte superior da alma, a inteligível que é "santa e pura", poderá ver as "razões na mente divina": Sed anima rationalis inter eas res, quae sunt a Deo conditae, omnia superat et Deo proxima est, quando pura est; eique in quantum caritate cohaeserit, in tantum ab eo lumine illo intellegibili perfusa quodammodo et illustrata cernit non per corporeos oculos, sed per ipsius sui principale quo excellit, id est, per intellegentiam suam, istas rationes, quarum visione fit beatissima. (Mas a alma racional, dentre as coisas que foram criadas por Deus, supera a todas e é a que está mais perto de Deus, quando é pura. E tanto quanto a ele adere pela caridade, banhada, por assim dizer, e iluminada por aquela luz inteligível, enxerga as razões em cuja visão encontrará a felicidade suprema, não pelos olhos do corpo, mas por aquele seu olho principal no qual se sobressai, isto é, por sua inteligência. Tradução de Moacy Novaes, In: Discurso, vol. 40, 2010, p. 380). A qualificação da alma como "santa e pura", a nosso ver, não deve ser interpretada como despreendimento total das coisas sensíveis, pois em linhas anteriores Agostinho diz que toda a criatura está contida no seu "genêro segundo certa natureza" (omnia quae sunt, id est, quaecumque in suo genere propria quadam natura continentur ut sint). Então a ordem da criação atesta a racionalidade do criador, que contém as ideias ou formas ou espécies. Resta investigar a "prática do mal", que, segundo a passagem de Plotino citada, não se imputa ao intelecto responsabilidade. Em div. qu. 46, Agostinho não trata da falsidade diretamente - que consiste em tomar 
A alma intelectiva (nous) não peca, pois, sendo a parte mais alta da alma, não é responsável pelo pecado, por conseguinte, a falta tem origem na complexidade interna do composto humano "anfíbio", cuja potência inferior não pode escapar à multiplicidade da vida orgânica. A "prática do mal", ou o erro moral, ocorre quando a parte superior da alma não é exercitada em ato ${ }^{418}$, isto é, a parte inferior movimenta a alma sem esperar o juízo raciocinante do intelecto. Há, pois, uma passividade e inculpabilidade da alma intelectiva que no caso do erro não chega a ser acionada.

O homem pratica o mal na medida em que se deixa confiscar a razão pela sua parte inferior. Segundo Touillard, analisando as Enéadas 1,1,9, a falta é um “desconhecimento do melhor de nós mesmos por nós mesmos" ${ }^{419}$; logo, uma alienação de si, como ser racional, que não está cindido senão que adormecido. 0 melhor de nós mesmos permanece não caído e a ele não é aberta a possibilidade de pecar. É preciso dizer que a teoria moral de Plotino é um campo fértil de estudo e que, atualmente, levanta várias disputas entre especialistas. Evidentemente, não pretendemos nos alongar. Apenas, partilhamos ao menos duas opiniões.

Jesus Igal:

A teoria do pecado aqui proposta dista muito de ser satisfatória (cf. a crítica de Proclo, In: Timaeum DIEHL, III, pág. 334), sobretudo se se tem em conta que, segundo Plotino, o arbítrio reside na inteligência e na alma racional (VI,8,3-6). Resulta, pois, que,

\footnotetext{
"imaginações" como verdadeiras-, mas a referência moral da alma "pura e santa" indica que o hiponense não salvaguarda o intelecto do pecado, como erro que se daria num estado de dormência da alma intelectiva.

418 id, idem "E possível ter o inteligível em nós e não tê-lo a mão". Jesus Igal comenta que o inteligível está sempre em ato primeiro, pois o intelecto "ele mesmo é ato". Mas há um "segundo ato", que pode não ser exercido. Porfírio. Vida de Plotino, Enéadas I-II: 1982, p. 197.

419 cf. Trouillard. L'impeccabilité de l'esprit, selon Plotin. In: Revue de I'histoire des religions, tome $143 \mathrm{n}^{\circ} 1,1953$. pp. 19-29.
} 
paradoxalmente, onde há arbítrio, não há pecado e onde há pecado, não há arbítrio. Ademais, propriamente, a mesma alma "passional" (=imagem da alma) é uma forma impassível $(1 \mathrm{II}, 5,4)$. Então, como pode pecar e como pode sofrer castigo? ${ }^{420}$

Em acordo, refere Armstrong que a alma para Plotino:

É na sua verdadeira natureza, essencial natureza divina, ainda que em degrau subordinado. Natureza divina no sentido que exclui qualquer alteração fundamental, ou qualquer queda real, corrupção, pecado ou perda de sua verdadeira natureza, e consequentemente qualquer necessidade ou possibilidade de redenção. ${ }^{421}$

Este breve balanço da questão é suficiente para retornarmos para a análise de Sobre as Duas Almas, pois podemos agora perceber com clareza que Agostinho, desde o início, faz uso do vocabulário platônico acerca da alma para adequar o útil instrumental filosófico ao seu interesse, mas altera-o substancialmente. O hiponense deve se afastar de qualquer concepção de alma superior não caída, mantida naturalmente divina, e, consecutivamente, excluída da responsabilidade do pecado e da necessidade de redenção.

Agostinho parece compreender que a inserção do pecado no seio da alma intelectiva causará problemas. Mas afirma, a despeito das dificuldades, "sente-se único" (unam me sentio), isto é, apesar

\footnotetext{
${ }^{420}$ a teoría del pecado aquí propuesta dista mucho de ser satisfactoria, sobre todo si se tiene en cuenta que, según Plotino, el albedrío reside en la inteligencia y en el alma racional (VI 8, 3-6). Resulta, pues, que, paradójicamente, donde hay albedrío, no hay pecado, y donde hay pecado, no hay albedrío. Además, propiamente, la misma alma «pasional» (= la imagen del alma) es una forma impasible (III 6, 4, 30-52). Entonces, ¿cómo puede pecar y cómo puede sufrir castigo? id, p. 200. Consultar também Trouillard. L'impeccabilité de l'esprit, selon Plotin. In: Revue de I'histoire des religions, tome $143 \mathrm{n}^{\circ} 1,1953$. pp. 19-29.

${ }^{421}$ It is in its true.. essential nature divine, though in a subordinate degree, in a sense which excludes any fundamental change, any real fall, corruption, sin or loss of its true nature, and therefore any need or possibility of redemption. Armstrong, Arthur Hilary Augustine and christian platonism, In: Villanova University. Lecture 1966, p.3.
} 
da inclusão do pecado no âmbito da alma superior, compreende-se como única alma de única vontade. Tal conjunção dará ocasião para apresentar as questões acerca do homem de um modo nada platônico, ou seja, redefine o dinamismo das partes internas da alma, com vista a não esconder o caráter falível do gênero humano, adoecido em sua parte mais excelente, a alma superior intelectiva. Isso em distinção da tradição platônica que conferia as almas puras e inteligíveis, conforme testemunha Armstrong, "qualidade de imutabilidade e impecabilidade" ${ }^{422}$.

\section{I,5,3 Pecado: hábito ( CONSUetudo) e I Mi taÇão.}

Se, anteriormente, Agostinho colocava entre aspas a metafísica platônica, a fim de estabelecer, pela intuição do cogito, a unidade da alma como vida volitiva, ao final do tratado, recoloca a alma racional volitiva no contexto da distinção moral entre inteligíveis e sensíveis, interior e exterior ${ }^{423}$. Nesse quadro da ordem hierárquica das naturezas dos bens, a alma superior é influenciada por esta vida temporal, reconhecendo certo limite da capacidade volitiva da alma racional em se manter na contemplação das coisas espirituais. Agostinho reconhece um fato (factum est nobis) que demanda investigação:

É fato que se tornou difícil se abster das coisas carnais (factum est nobis a carnalibus difficile abstinere), apesar de que nosso verdadeiro pão é espiritual; e é pelo labor que nós agora comemos nosso pão. E não

\footnotetext{
${ }^{422}$ idem, p. 6 "Plotinus,as we have seen, gives his divine souls the qualities of immutability and impecability".

${ }^{423} \mathrm{cf}$. duab. an. XII,19 "o inferior e o superior ou, o que talvez possa ser melhor expresso, o exterior e o interior. Esses são os dois gêneros a que nós, há pouco, nos referíamos sob o nome de coisas sensíveis e inteligíveis, aos quais estamos mais acostumados a chamar de coisas carnais e espirituais".
} 
sem punição pelo pecado de transgressão pelo qual nos tornamos de imortais, mortais. ${ }^{424}$

Possivelmente ${ }^{425}$, testemunha-se a fase embrionária da noção do "pecado original", o qual Agostinho não deixará de enfatizar nas Retratações:

As almas não podem de modo algum ser más por natureza (cf. duab an. XVII). Se sou perguntado de que modo compreendo o que o apóstolo diz: "Somos por natureza filhos da ira como os demais" (Paulo, Efésios II,3); respondemos que ao falar de natureza quis que entendessem natureza dita em modo próprio, na qual somos criados sem vício. E, aquela natureza assim chamada por causa de sua origem é uma origem contida de vício, que é contra a natureza. ${ }^{426}$

Contra a oposição pelagiana à doutrina do pecado original, Agostinho distingue dois modos de significar "natureza": o primeiro refere ao modo próprio da substância criada, cuja essência não reputa vício algum. Logo, por essa primeira significação do termo, "natureza pecaminosa" é uma expressão contraditória, visto que o "pecado é um ato da vontade e não da natureza" (cf. duab. an XVII);

${ }^{424}$ duab. an. XIII,19. Sed factum est nobis difficile a carnalibus abstinere, cum panis verissimus noster spiritalis sit. Cum labore namque nunc edimus panem. Neque enim nullo in supplicio sumus peccato transgressionis mortales ex immortalibus facti.

425 "Augustine's thinking about the will's bondage to habit (consuetudo), and therefore about the working of God's grace, began in his works On Two Souls (391) and Against Fortunatus (392) and that represent another sharp break between his outlook at Cassiciacum and his outlook in the Confessions" William S. Babcock Church History 1998

(ver J. Wetzel wetzel, p. 97 "The connection between Adam's voluntary sin and the involuntary sins of his descendants is admittedly mysterious, and its is difficult to understand how the notion of voluntary sin gains any further clarity by virtue of its restriction to an original agent").

${ }^{426} \mathrm{cf}$. Retr. XV,6. Itemque in eo quod dixi: Natura esse malae animae nullo modo queunt (duab. an. XVII), si quaeritur quomodo accipiamus quod ait Apostolus: Fuimus et nos natura filii irae, sicut et ceteri; respondemus naturam in his verbis meis me intellegi voluisse illam, quae proprie natura dicitur, in qua sine vitio creati sumus. Nam ista propter originem natura appellatur, quae origo utique habet vitium, quod est contra naturam.

O Agostinho maduro deixará mais claro a relação entre servidão e liberdade, pelo desenvolvimento da noção de graça, precisamente nos tratados apologéticos contra Pelágio. 
segundo, o filosófo esclarece que pecamos pela natureza quanto à origem (referência ao pecado adâmico), isto é, somos, na origem, viciados por natureza por meio da soberba que todos partilhamos no primeiro homem. Assim, quanto a origem "chamamos de natureza o que é uma contra-natureza".

Após certo otimismo da potência da vontade em alcançar a vida virtuosa, o bispo passa a enfrentar a experiência negativa de poder cumprir a conversio ad Deum e adversio ad mundum, reconhecendo que o projeto ascensional pela percepção da ordem natural é uma "tarefa árdua e dificílima" (cf. duab. an. párag. 10 e 19). Não por acaso alguns estudiosos tem apontado ${ }^{427}$ que os primeiros anos do presbiterado de Agostinho foram marcados por reflexões acerca do limite do ideal antigo de "sabedoria virtuosa".

Essa dificuldade tem alcances profundos no pensamento do hiponense, de modo que, como já temos referido desde nossa introdução, Agostinho, no tratamento contra a gnose maniqueia, não se limita à crítica ontológica, como se essa fosse separada da própria experiência moral para a qual é comissionado a viver ${ }^{428}$. Esse aspecto da filosofia agostiniana permite, como vimos, Ricoeur referir o bispo como o elaborador de um conceito gnóstico anti-gnóstico, uma vez que os maniqueus não tinham nenhum otimismo quanto ao alcance da virtude pela capacidade raciocinante. Note-se como Agostinho bem descreve a angústia maniqueia quando faz Fortunato falar:

Agostinho: Segundo a vossa fé, eu poderia dizer: "Quem fez? O quê foi cometido? Estive contigo, fui íntegro, nenhuma mancha me contaminou; tu me enviaste aqui, tu tens sofrido necessidade, tu cuidaste de teus reinos quando estava a ponto de sobrevir uma grande ruina e devastação. Se tu conheces a

427 Consultar nossa introdução.

${ }^{428}$ cf. Gn c. man. II,9,12. 
necessidade pela a qual sou oprimido, e já não posso respirar, a que não posso oferecer resistência, por que me acusas como se tivesse pecado ${ }^{429}$.

O hiponense não está insensível à angústia gnóstica. O “ar que falta ao maniqueu" é também o ar que lhe falta. $O$ desafio, então, é retomar a angústia sobre outro modelo teórico. Em Sobre as Duas Almas XIX, podemos verificar como Agostinho faz essa passagem. O hábito (consuetudo) ${ }^{430}$ não é apenas uma prática difícil de se livrar pelo fato de que muito se fez aquilo. O hábito é ação contrária à justiça divina inserida na cisão da alma intelectiva, isto é, é o nome provisório do que haveria de ser conceitualizado com mais detalhes na polêmica contra Pelágio, isto é, pecado original: condição de milícia no interior da natureza da alma - uma contra-natureza portanto.

Mas fato é que se tornou para nós difícil de abster das coisas carnais, apesar de que nosso verdadeiro pão seja espiritual. Agora, nós comemos o pão através de

\footnotetext{
${ }^{429}$ Fort. 21 qui possum dicere secundum fidem vestram: Quid feci? quid commisi? Apud te fui, integer fui, nulla labe contaminatus fui: tu me huc misisti, tu necessitatem passus es, tu cavisti regnis tuis, cum magna eis labes et vastitas immineret. Cum ergo noveris necessitatem qua hic oppressus sum, qua respirare non potui, cui resistere non potui; quid me accusas quasi peccantem?

${ }^{430}$ A nosso ver, Agostinho utiliza "consuetudo" em duab. an no mesmo sentido que usaria em conf. VII,17,23 et mirabar quod iam te amabam, non pro te phantasma, et non stabam frui deo meo, sed rapiebar ad te decore tuo moxque diripiebar abs te pondere meo, et ruebam in ista cum gemitu; et pondus hoc consuetudo carnalis. - e eu admirava que agora eu te amava, não a tua imagem em teu lugar. Mas eu não permanecia na fruição do meu Deus: elevado com ímpeto a tua beleza, logo precipitava de ti atraído pelo meu peso... esse peso eram os meus hábitos carnais. Atente-se ao fato de que Agostinho ganha consciência de sua distância (regio dissimilitudinis) a Deus, na medida em que contempla parcialmente a beleza divina. o hábito carnal que aliena o homem da verdadeira beleza é tão mais incompreensível quanto mais se frui de Deus: "The mystery of his descent is compounded by the oddness of his place of departure. Within himself he has encountered God's light and begun to intuit a connection between love and knowledge, but he does not see from God's perspective, not at first and, I would add, never fully. He situates his point of view in a regio dissimilitudinis-a region of unlikeness, or what I prefer to translate, less literally, as a place of exile. (Confessions 7. 10.16: Et inveni longe me esse a te in regione dissimilitudinis.)" James Wetzel. The question of consuetudo carnalis in Confessions 7.17.23. In: Augustinian Studies 2000, p. 166.
} 
duro trabalho e, não sem suplício, nos tornamos pelo pecado de imortais, mortais. Por isso que, embora nos esforcemos para o melhor, nosso hábito estabelecido pela carne e pelo nosso pecado começa de algum modo a militar contra nós e a nos criar dificuldades. Por isso que alguns estultos supõem, pela sua obtusíssima superstição, que exista um outro gênero de alma que não provém de Deus ${ }^{431}$.

A recusa do "pão espiritual" e a pena na forma de "duro trabalho" fazem evidentemente referência à narrativa da queda segundo o Gênesis. Apesar de sermos criados para alimentarmos facilmente das coisas espirituais, após a queda, "comemos o pão [espiritual]" com muito esforço e trabalho, pois constatamos em nós uma mortalidade herdada que se traduz num “hábito estabelecido em nós pela carne e pelo pecado, que de algum modo milita contra nós e nos dificulta" o alcance do pão espiritual. (consuetudo facta cum carne et peccata nostra quodam modo militare contra nos, et difficultatem nobis).

O deslocamento argumentativo deve ser sublinhado: já não se fala de pecado como definição. Agora, pecado é história e imagem bíblica. O pecado é uma dificuldade da experiência "factual" que demanda conceito (factum est nobis.), isto é, o pecado é ele mesmo um in-conhecível ${ }^{432}$, que cria a necessidade de reflexão, e permite a alegorização do texto bíblico. Busca-se a descrição de estado em que a alma milita contra a própria natureza, tornando-se "de imortal; mortal", em sentido espiritual. Parece inevitável reconhecer que o esforço da alma superior para as coisas superiores e melhores não é

\footnotetext{
${ }^{431}$ duab. an. XIII,19 Sed factum est nobis difficile a carnalibus abstinere, cum panis verissimus noster spiritalis sit. Cum labore namque nunc edimus panem. Neque enim nullo in supplicio sumus peccato transgressionis mortales ex immortalibus facti. I deo contingit ut cum ad meliora conantibus nobis, consuetudo facta cum carne et peccata nostra quodam modo militare contra nos, et difficultatem nobis facere coeperint, nonnulli stulti aliud genus animarum quod non sit ex Deo superstitione obtusissima suspicentur.

${ }^{432}$ Se nos permite o neologismo.
} 
suficiente para superar a prisão do "hábito" (consuetudo) pelo que o homem permanece voluntariamente como que escravo à carne, mas o voluntário nullo cogente é acrescido de uma herança de uma tendência que põe “o involuntário no seio do voluntário"433. Instaurase, assim, na interioridade mais sublime uma milícia do espírito contra o espírito; e não da carne contra o espírito ${ }^{434}$ : “De alguma forma, o nosso hábito milita contra nós" (peccata nostra quodam modo militare contra nos) ${ }^{435}$.

A milícia do espírito contra o espírito, portanto, expõe algo de errado na relação de ofício entre seus "dois gêneros de alma". Resta considerar, então, as atividades próprias a cada gênero no "interior" dessa "unidade diversa" a que chamamos alma:

E, finalmente, é possível que elas não sejam totalmente más, mas em seu gênero, embora inferior, exerça o que lhe é próprio, sem pecado: mas se estas almas superiores, para as quais a mais alta justiça, que governa as coisas, concedeu a mais excelente atividade, quiserem seguir e imitar as almas inferiores, elas, então, se tornam más pelo pecado; não porque elas imitam almas más, mas porque as almas superiores imitam mal. ${ }^{436}$

A alma inferior deve agir segundo o que lhe é próprio, isto é, segundo suas próprias obras (opus proprium). Com efeito, é próprio e natural que alma inferior mova-se em direção aos corpos,

433 Ricoeur, P. O "pecado original": estudo de significação, In O conflito das interpretações. Ensaios de hermenêutica. Porto: Res Editora, 1989. p. 281.

434 cf. duab. an. XIII. 20. Quanquam etiam si eis concedatur inferiore alio genere animarum nos illici ad turpia, non inde conficiunt aut illas natura malas esse. "E ainda, mesmo se concedesse a eles que nós somos seduzidos aos atos vergonhosos pelo gênero inferior de alma, eles não concluem disso que estas almas inferiores são más".

435 cf. duab. an. XIII,19.

${ }^{436}$ duab. an. XIII,20 deinde, ut omnino malae non sint, sed in suo genere, quamvis inferiore, opus proprium sine ullo peccato exerceant: istae autem superiores quibus actionem longe praestantiorem rerum moderatrix iustitia summa tribuerit, si illas inferiores sequi et imitari voluerint, peccando fiunt malae, non quia malas, sed quia male imitantur. 
sendo garantido o livre acesso aos sensíveis sem prejuízo moral. No entanto, o pecado ocorre quando a alma superior, recusando seu justo lugar na escala hierárquica dos seres, imita as atividades próprias da alma inferior.

Pode gerar estranhamento que Agostinho anuncie no final desse excerto que as almas tornem-se más por "imitar mal as almas inferiores" (sed quia male imitantur), pois estaria implícito que haveria algum modo bom de imitar almas más. E estaremos, então, tentados a traduzir por algo assim: "mas se [as almas superiores] quiserem seguir e imitar as [almas] inferiores, elas, então, tornam-se más pecando; não porque imitam almas más, mas porque a imitação é má [das almas inferiores]". Mas, se assim, o que seriam essas almas inferiores? Não se introduz de novo, aqui, uma duplicidade da alma? De fato, em ambas tentativas fracassamos em "consertar" o hiponense.

Há, pois, uma sutileza difícil de traduzir. Evidentemente, em tomando a forma mais literal, alguém pode inferir que exista um modo bom de imitar a alma inferior, pois a imitação "verdadeira" é somente aquela em que algo inferior imita a superior. Por outro lado, se abandonarmos a adjetivação da alma e admitirmos que Agostinho refira-se com os adjetivos "superior" e "inferior" mais aos dados recolhidos na alma do que explicitamente ao substantivo "alma", nos arriscamos menos, pois estaria completamente afastadada qualquer possibilidade de partição efetiva da alma. Mas, então, não nos arriscamos de novo a perder a distinção essencial do tratado que visa atribuir atividade e responsabilidade à parte intelectiva da alma?

Pensamos que Agostinho está jogando com as palavras, pois se diz "alma inferior", vocabulário comum de gnósticos e neoplatônicos, é para precisamente referir-se ao conteúdo sensível da alma ou mesmo a sua potência sensorial orietanda aos corpos - 
então "conteúdo inferior da alma" traduz melhor do que "alma inferior"-. Ora, o texto não dá forte indícios gramaticais de que Agostinho qualifique o conteúdo da alma ao invés da alma mesma, o que nos leva adjetivar o substantivo "alma", de modo que preferimos a tradução mais literal que adjetiva a "alma". Portanto, o que teria levado Agostinho a manter a espantosa fórmula gramatical dizendo que "a alma superior torna-se má pecando quando imita mal"?

A nosso ver, o retor filósofo pretende marcar a mirabolante capacidade mimética da alma intelectiva imitar o que the é inferior, pois imitar nesse contexto é querer possuir o objeto do desejo e não há alma sem intencionalidade a qualquer coisa, seja sensível ou inteligível, carne ou espírito. Lembre-se de que a vontade é inerente à vida, elemento da tríade intuitiva do espírito que é, vive/quer e sabe. Então "imitar mal" significa pecar pela atividade volitiva da parte intelectiva da alma, que não está adormecida, mas ativa. Se nós hoje estranhamos a fórmula literal, quanto mais os "doutíssimos" platônicos. Destarte, Agostinho afasta-se definitivamente tanto da noção de alma impotente e fraca, que não é capaz de resistir ao ataque das trevas ("entrevasamento" cf. maniqueísmo), quanto daquela noção de alma intelectiva não acionada (cf. Plotino, alma superior presente mas não em ato).

\section{I,5,4 AdMI RÁVEL TENSÃo entre ASCENSÃo de HÁBIto.}

O belo parágrafo 23 das Confissões VII é um exemplo da tensão espantosa (et mirabar...), que Agostinho mantém entre a elevação possível dos sensíveis aos inteligíveis por via contemplativa e a constatação de um impedimento, um hábito, uma fraqueza interior que impede a "fixação do olhar" contemplativo sobre a 
“ordem criada" ${ }^{437}$. Em razão da imbricação temática que queremos demonstrar, comentamos o parágrafo na íntegra:

\begin{abstract}
E admirava-me (et mirabar) por já te amar a ti, não a um fantasma em vez de ti, e não persistia em fruir do meu Deus, mas era arrebatado (rapiebar) para ti, pela tua beleza, e logo a seguir era arrancado de ti, pelo meu peso (diripiebar abs te pondere meo), e caía nestas coisas, gemendo; e esse peso era o hábito carnal (consuetudo carnalis) ${ }^{438}$.
\end{abstract}

Repare que, logo nas primeiras linhas, Agostinho chama atenção para algo espantoso (et mirabar). Por um lado, ele era arrebatado (rapiebar) pela contemplação da beleza divina; por outro (moxque), era arrastado (diripiebar) pelo peso do hábito carnal (consuetudo canalis). Situação surpreendente, porque a condição humana de ascensão à Deus aparece tensionada entre possibilidades contraditórias.

De fato, pelo fluxo do livro VII ${ }^{439}$, esperava-se que a alma, pela sua capacidade raciocinante, pudesse por si elevar-se a Deus a partir do julgamento da cadeia hierárquica dos seres. Chegaria à existência de Deus, à contemplação da beleza divina, passando pela beleza dos corpos, visto que a criação está ordenada em qualidade de ser e pode ser percebida pela alma quando essa internaliza tantos dados sensíveis quanto inteligíveis. O próprio Deus poderia ser "recuperado" na alma pela memória; não apenas para ser conhecido por ela, mas para que a própria alma se unisse (cohaererem) com a

437 Consultar J. Wetzel. The question of consuetudo carnalis in Confessions VII, 23. In : Augustinian Studies 31. 2000.

438 conf. VII, 17,23 Et mirabar, quod iam te amabam, non pro te phantasma, et non stabam frui Deo meo, sed rapiebar ad te decore tuo moxque diripiebar abs te pondere meo et ruebam in ista cum gemitu; et pondus hoc consuetudo carnalis. Tradução de Arnaldo do Espírito Santo. Imprensa Nacional - Casa da Moeda, 2001. Todas as citações do parágrafo 23 seguirão essa tradução.

${ }^{439}$ Consultar também o livro II do lib. arb. 
fonte da qual é semelhança e dessa síntese entre inteligíveis e sensíveis, a alma se elevasse:

Mas comigo estava a lembrança de ti, e não duvidava de forma alguma de que existe um ser a que me pudesse unir, mas eu ainda não era capaz de me unir (neque ullo modo dubitabam esse cui cohaererem, sed nondum me esse qui cohaererem), porque o corpo, que é corruptível, torna a alma pesada, e a morada terrena oprime a mente que pensa muitas coisas, e estava certíssimo de que as tuas coisas invisíveis, bem como a virtude sempiterna e a tua divindade, se contemplam e compreendem (intelecta conspicuntur), desde a criação do mundo, por meio das coisas que foram criadas. Procurando por que motivo aprovava eu a beleza dos corpos, quer celestes, quer terrestres, e porque estava eu pronto a emitir um juízo correto a respeito das coisas mutáveis e a dizer: Isto deve ser assim, aquilo não deve ser assim, buscando, pois, o motivo por que julgava, quando assim julgava, tinha descoberto a imutável e verdadeira eternidade da verdade, acima da minha mente mutável. E assim, gradualmente (in gradatin), desde os corpos até à alma, que sente através do corpo, e da alma até à sua força interior, à qual o sentir do corpo anuncia as coisas exteriores, tanto quanto é possível aos animais irracionais, e daqui passando de novo à capacidade raciocinante, à qual compete julgar o que é apreendido pelos sentidos do corpo; a qual, descobrindo-se também mutável em mim, elevou-se até à sua inteligência e desviou o pensamento do hábito (consuetudo), subtraindo-se às multidões antagônicas dos fantasmas, para que descobrisse com que luz era aspergida quando clamava, sem nenhuma hesitação, que o imutável deve antepor-se ao mutável, o motivo pelo qual conhecia o próprio imutável - porque, se não o conhecesse de algum modo, de nenhum modo o anteporia, com certeza absoluta, ao mutável - e chegou àquilo que é, num relance de vista trepidante ${ }^{440}$.

\footnotetext{
440 conf. VII, 17,23 Sed mecum erat memoria tui, neque ullo modo dubitabam esse, cui cohaererem, sed nondum me esse, qui cohaererem, quoniam corpus, quod corrumpitur, aggravat animam et deprimit terrena inhabitatio sensum multa cogitantem, eramque certissimus, quod invisibilia tua a constitutione mundi per ea, quae facta sunt, intellecta conspiciuntur, sempiterna quoque virtus et divinitas tua. Quaerens enim, unde approbarem pulchritudinem corporum sive caelestium sive terrestrium et quid mihi praesto esset integre de mutabilibus iudicanti et dicenti: "Hoc ita esse debet, illud non ita", hoc ergo quaerens, unde iudicarem, cum ita
} 
Muito se pode apreender desse rico excerto. Para nosso interesse, apenas apontamos a tensão entre capacidade ascensional do espírito e o hábito (consuetudo). Agostinho enfatiza que já não há dúvida acerca da imutabilidade incorporal do ser divino, o que, no quadro geral do livro VII, representa um grande avanço, pois no prólogo não se duvidava da intangibilidade e imutabilidade divina, no entanto, a natureza incorporal de Deus permanecia obscurecida pelo problema do mal.

Após a descoberta da interioridade (cf. Confissões VII, 11,17), Agostinho afirma "não duvidar" de que existisse o ser incorporal do qual tudo era e tudo derivava. Estava "certíssimo" de que o divino pudesse ser compreendido infinito em outro sentido, ou seja, um infinito incorporal compreendido pela alma intelectiva, cuja visão não se dá pelos sentidos - “descansei um pouco de mim e a minha loucura adormeceu; e despertei em ti, e vi-te infinito de outra maneira, e essa visão não era tirada da carne" ${ }^{441}$ - e que, por sua vez, pode ajuizar corretamente os valores dos sensíveis. A elevação até a sua inteligência desviaria 0 pensamento do hábito (consuetudo), afastando a falácia das fantasias (phantasmata). Tudo estava então, segundo a razão e inteligência, coerentemente ajustado para a unidade da alma com o criador.

\footnotetext{
iudicarem, inveneram incommutabilem et veram veritatis aeternitatem supra mentem meam commutabilem. Atque ita gradatim a corporibus ad sentientem per corpus animam atque inde ad eius interiorem vim, cui sensus corporis exteriora nuntiaret, et quousque possunt bestiae, atque inde rursus ad ratiocinantem potentiam, ad quam refertur iudicandum, quod sumitur a sensibus corporis; quae se quoque in me comperiens mutabilem erexit se ad intellegentiam suam et abduxit cogitationem a consuetudine, subtrahens se contradicentibus turbis phantasmatum, ut inveniret quo lumine aspergeretur, cum sine ulla dubitatione clamaret incommutabile praeferendum esse mutabili, unde nosset ipsum incommutabile (quod nisi aliquo modo nosset, nullo modo illud mutabili certa praeponeret) et pervenit ad id, quod est in ictu trepidantis aspectus

441 conf. VII, 14,20 cessavi de me paululum, et consopita est insania mea et evigilavi in te et vidi te infinitum aliter, et visus iste non a carne trahebatur
} 
No entanto, o hiponense reconhece a distância ou dessemelhança, quando diz: "mas eu ainda não era capaz de me unir" (neque ullo modo dubitabam esse cui cohaererem, sed nondum me esse qui cohaererem). A conjunção adversativa "mas" não pode ser menosprezada, pois ela é a razão do espanto (et mirabar) que abrira o parágrafo. Percebe-se claramente a tensão entre o exercício necessário da razão e o limite de alcance da verdade. Mais admirável ainda é o fato de que não é o corpo que dá o limite da alma intelectiva, pois o espírito não está no corpo como a alma está na tumba. Ao contrário, a capacidade raciocinante da alma é o bem mais próximo de Deus, no entanto, esse compreende-se “mutável no tempo" e diferente do Eterno.

O limite da alma intelectiva em alcançar a Deus tem dois fatores: primeiro, o princípio de alteridade pelo qual a natureza divina transcende todo homem explica a própria criação do livre arbítrio como bem: "O que é feito, não pode ser igual ao que o fez (...). Mas é melhor que o homem seja bom pela vontade do que pela necessidade" ${ }^{442}$. Portanto, foi necessário dar ao homem o livre arbítrio. Nesse momento, já não se fala de um mal naturalizado, e, apesar do texto nomear o "peso da alma" como "hábito carnal", não se trata da famosa dicotomia entre alma e corpo, mas de uma "região de diferença" (regio dissimilitudinis cf. Confissões. VII, $10,16^{443}$ ), estabelecida desde a criação e agravada pela criatura quando pela vontade se deixa seduzir pelo mal uso do livre arbítrio $^{444}$. Segundo, a alma intelectiva, capacidade raciocinante do homem, pela força do "hábito" e "fraqueza" da vontade, é incapaz de

442 div. qu. 2 Omne quod fit, ei a quo fit par esse non potest. Alioquin iustitia, quae sua cuique tribuere debet, de rebus auferatur necesse est. Hominem ergo Deus cum fecit, quamquam optimum fecerit, non tamen id fecit quod erat ipse. Melior autem homo est qui voluntate quam qui necessitate bonus est. Voluntas igitur libera danda homini fuit. Com alteração nossa.

${ }^{443}$ cf. nosso seção I,2,4 .

${ }^{444}$ cf. div. qu. 2 ; conf. $111,6,11$. 
"fixar o olhar" sobre a ordem criada, desafiando o próprio projeto ascensional por contemplação.

Então, contemplei e compreendi as tuas coisas invisíveis por meio daquelas coisas que foram feitas, mas não consegui fixar o olhar e, repelido de novo pela minha fraqueza, entregue uma vez mais aos meus hábitos, não levava comigo senão uma lembrança de quem ama, como quem deseja alimentos bem cheirosos que ainda não podia comer. ${ }^{445}$

O reconhecimento dessa fraqueza interna faz Agostinho aprofundar o sentido da primeira frase do parágrafo, quando animado pelas descobertas platônicas dizia ter se afastado das ilusões maniqueias e com confiança admirava-se do amor que tinha a Deus (et mirabar quod iam te amabam). Agora, após o "teste" do projeto ascensional, retoma a palavra "amor" em outro sentido, pois diz: "não levava comigo senão uma lembrança amorosa" (mecum ferebam nisi amantem memoriam). Evidentemente, o filósofo não cai em ingênua contradição; faz do amor a Deus um conceito circular, cuja presença e ausência se revezam em mútua indicação. Deus está, paradoxalmente, presente e ausente, imanente e transcendente.

Eis a circularidade entre "ascensão" e "diferença" que pretendemos ressaltar do texto. Quanto mais alto sobe na compreensão da ordem, mais diferente (baixo em regio dissimilitudinis) se constata. A contemplação da ordem criada (ex ordine) faz a descoberta da alma intelectiva capaz de compreender o divino e organizar as representações sensíveis. Mas, a alma descobre-se ela também mutável no tempo, e, misteriosamente precipitada no "hábito carnal" (cosuetudo carnalis). Por isso, a

445 conf. VII, 17,23 Tunc vero invisibilia tua per ea quae facta sunt intellecta conspexi, sed aciem figere non evalui et repercussa infirmitate redditus solitis non mecum ferebam nisi amantem memoriam et quasi olefacta desiderantem, quae comedere nondum possem. 
contemplação da beleza divina é apenas parcial: "um cheiro" que não se atualiza em alimento senão no modo próprio da confissão.

Destarte, o conhecimento de Deus requer que se adentre nas complexidades da natureza da alma, que apreende o divino e as coisas sensíveis por uma circularidade de ascensão e descensão (confessada). A insatisfação é tanto psicológica-confessional, quanto especulativa-racional. Poderia pensar que na medida em que a fé e razão avançam, tanto maior seria a paz. No entanto, admiravelmente, não é assim a trajetória agostiniana ${ }^{446}$.

\title{
Conclusão - Arrependi mento e Confissão.
}

Agostinho pode, nas linhas finais de Sobre as Duas Almas, relacionar arrependimento-culpabilidade no âmbito da interioridade de uma única alma que peca:

\begin{abstract}
Alguém pode dizer que não peca, mas nenhum bárbaro ousará dizer que, em pecando, não seja necessário se arrepender. Sendo assim, pergunto de qual daqueles dois gêneros de almas pertence o arrependimento do pecado? Eu sei que não pertence àquele gênero que não pode fazer o mal nem àquele que não pode fazer o bem. Portanto, para usar as palavras dos maniqueus, se a alma das trevas se arrependesse do pecado, essa alma não seria da substância do sumo mal. Se, por outro lado, a alma das luzes se arrependesse, ela não seria da substância do sumo bem. ${ }^{447}$
\end{abstract}

\footnotetext{
${ }^{446}$ O'Donnel bem percebe que o tormento de Agostinho se intensifica a medida que seu conhecimento avança. O'Donnel, J. Augustine. 1985, p. 71.

${ }^{447}$ duab. an. XIV, 22 Potest aliquis dicere, non se peccare: non autem sibi esse, si peccaverit, poenitendum, nulla barbaries dicere audebit. Quae cum ita sint, quaero ex duobus illis generibus animarum, cuius sit poenitere peccati? Scio quidem neque illius esse posse, qui male facere, neque illius qui bene facere non potest: quare, ut eorum verbis utar, si animam tenebrarum peccati poenitet, non est de substantia summi mali; si animam lucis, non est de substantia summi boni.
} 
A questão não parece ser mais a possibilidade de alguém pecar, mas, tendo pecado, investiga-se se o arrependimento (poenitentia) é necessariamente um bem. Agostinho visa expor a última incoerência interna da doutrina maniqueia, pois, se, para eles, a alma má é a única responsável pelo pecado, então ela somente deve arrepender-se; no entanto, se o arrependimento é um bem, não poderia provir da alma má. O contrário é também absurdo: se alma boa é a única capaz de praticar o bem do arrependimento, quando se arrependeria se ela não é a responsável pelo pecado?

Pois este sentimento de arrependimento, que é muito útil, supõe que haja o testemunho de que aquele que se arrepende pudesse tanto fazer o mal quanto fazer o bem. ${ }^{448}$

Dado que o pecado faz parte da vida (vontade), o arrependimento é o seu contraponto "útil"; mas não há condição de arrependimento na exterioridade e no constrangimento. A atividade, seja qual for, é prerrogativa irredutível da interioridade humana, cuja vontade garante movimento e liberdade. A culpabilidade é, pois, a consequência necessária da liberdade da vontade, cujo campo de deliberação é o infinito ${ }^{449}$ de responsabilidade individual.

\footnotetext{
448 duab. an. XIV, 22 Poenitendi enim affectus ille qui prodest, et male fecisse poenitentem, et bene facere potuisse testatur.

${ }^{449}$ Ricoeur, analisando os princípios de liberdade, recorre a Hegel para indicar que a passagem do pensamento grego para o cristianismo é a primeira passagem em direção à noção de liberdade subjetiva, conforme o temos em nossa modernidade. Para Hegel, a liberdade é concretizada apenas a partir do despertar do sujeito e é o "limite infinito da particularidade do sujeito" cf. seu Princípio da Filosofia do Direito, parág. 273. Diz Ricoeur: "la liberté doit être conçue comme infinie pour devenir subjective, au sens fort du mot; Hegel souligne sans cesse cette conjonction entre réflexion et infini. Or, cette infinitude est inconnue d'Aristote. Pour lui, le pouvoir de choisir n'est effectif que dans un champ limité de délibération au milieu de situations finies; la délibération porte sur les moyens plutôt que sur les fins; la vertu elle-même, en tant que milieu entre deux extrêmes, définit les règles de l'action finie. Une révolution s'est donc produite, qui a inversé la relation entre l'infini et le fini. Ce premier renversement, dit Hegel dans La Philosophie du droit, marque le tournant du monde grec au monde chrétien: «Le droit de la particularité à se trouver satisfaite, ou, ce qui est la même chose, le droit de la liberté subjective, constitue le point critique et central de la différence entre l'Antiquité et
} 
Desde então, entende-se a denúncia que Agostinho faz de um arrependimento sem interioridade. E abre-se um campo novo de encontro de si na dimensão do arrependimento, pois parece que o ponto de partida para se conhecer - na medida em que se conhecer é conhecer a sua alma - é o próprio desconhecimento de si. Com efeito, o arrependimento só é possível na interioridade cindida, recusando a causalidade de qualquer natureza, a pretensão da razão em encadear, discernir e juntar os dados. Destarte, desde o início, o cogito agostiniano nasce cindido, incapaz de ordenar a si mesmo segundo a percepção e recomendação (oikeiosis) da ordem natural.

Essa intuição do intelecto é o caminho inicial para a compreensão de si, mas não é suficiente como ponto de fundação como se fosse uma substância imóvel que atualiza o conhecimento. Ao contrário, para Agostinho, a alma é um fundamento frágil do conhecimento, pois nem está imóvel nem está adormecida: está cindida. Essa característica da alma retira totalmente a natureza do pecado e coloca uma dificuldade intransponível, a saber, que a própria causa do pecado seja ela mesma sem natureza, de modo que a vontade de pecar seria um nada substancial, um monstro.

Ainda que vontade seja recolocada como elemento inerente à vida, dado que resgata a natureza ontológica do movimento da

les Temps modernes. Ce droit, dans son infinité, est exprimé dans le christianisme et y devient le principe universel réel d'une nouvelle forme du monde. ». Désormais, à la métaphysique de l'action finie succède la métaphysique du désir de Dieu. Ce tournant peut être reconnu chez saint Augustin, pour qui la voluntas se révèle, dans sa grandeur terrible, dans l'expérience du mal et du péché; la liberté a le pouvoir de nier l'être, de « décliner » et de « défaillir », de se « détourner » de Dieu, de se «tourner vers » la créature; ce pouvoir redoutable - ce « pouvoirpécher » - est la marque de l'infini sur la liberté. Peut-être n'y a-t-il eu volonté et liberté dans la philosophie occidentale qu'après que la pensée eut été confrontée avec ce qu'Augustin appelle le « mode défectif » de la volonté. Ce serait une première manière d'expliquer a contrario l'absence du concept de liberté - et même de volonté - chez Aristote, s'il est vrai que cette absence est celle de la subjectivité et que la subjectivité moderne commence avec la méditation augustinienne sur la puissance de défection de la volonté libre. Paul Ricoeur, « LIBERTÉ », Encyclopædia Universalis [en ligne], consulté le 23 mars 2014. 
alma, permanece inconclusa a pretensão de conhecer a natureza da origem do pecado. O pecado original é um mistério e o arrependimento, visto assim, é o que resta fazer, pois, ainda que não se saiba a causa do pecado (o que é o pecado), percebe-se em si o movimento pecaminoso por afastamento do sumo ser.

\section{A CONFISSÃo}

Como resultado do exercício da razão que se percebe cindida em seus modos de ascensão, Agostinho é desafiado a tratar da falácia não como problema de ordem puramente intelectual, cuja capacidade raciocinante consiga por completo o afastamento do "hábito do pensamento"; mas deve de outra maneira buscar um tipo de expressão em que a cisão do conteúdo filosófico transpareça no modo linguístico. Evidentemente, não pretendemos analisar como o estilo confessional se ajusta aos avanços filosóficos; basta indicar que em Sobre as Duas Almas, diante da atenção que dá a angústia maniqueia, Agostinho inicia um estilo que, ainda incipiente, se mostra coerentemente alinhado com as novas preocupações filosóficas.

Tomemos a narração de dois eventos pessoais do tratado de 392, em referência ao período em que Agostinho fora auditor do maniqueísmo. Diz, primeiro, que os afetos quase familiares de amigos maniqueus o envolviam como num colo de sinuosa bondade. Em seguida, identifica a motivação profunda que provinha das vitórias contra cristãos imperitos ${ }^{450}$, alimentando o ímpeto juvenil no ardor das disputas; e ao lograr vitórias na condição de auditor maniqueu, renovava-se o amor fraterno entre eles. Agostinho

450 cf. duab. an. IX,11; quorum est unum familiaritas, nescio quomodo repens quadam imagine bonitatis, tamquam sinuosum aliquod vinculum multipliciter collo involutum. Alterum quod quaedam noxia victoria pene mihi semper in disputationibus proveniebat disserenti cum christianis imperitis. 
descreve aqui o ciclo vicioso do pecado. Os afetos fraternos que mantinham com os maniqueus eram alimentados pelas vitórias doutrinárias (assentimento ao verdadeiro), que por sua vez renova o amor fraternal. De fato, o desejo de ser amado no tempo precedeu o assentimento à verdade, lançando-o em um ciclo de falsidade. Essa circularidade viciada somente pode ser quebrada quando a "espantosa doença" (miris morbis) da alma encontrar cura na misericórdia divina, conforme se anunciava nas primeiras letras do proêmio (opitulante Dei misericordia). Há, pois, um esforço de ruptura que se demanda que Agostinho lamenta deveras não ter realizado quando auditor da seita. Note-se, Agostinho julgava a doutrina maniqueia como verdade, não porque tinha ciência da verdade, mas porque desejava que fosse verdade (non quia sciebam, sed quia optabam verum esse). Assim, o início da investigação acerca dessa condição humana inscrita num ciclo temporal pecaminoso se dá pela evidência da vontade precedente à compreensão da verdade ${ }^{451}$. Nesse sentido, refere J.L. Marion: "O tempo, como o fluxo em que se desvanece a liberdade e a consciência se dissipa, não aparece de início na análise conceitual da estrita filosofia, mas no diagnóstico consternador do pecado e da impotência que paralisam a vontade" ${ }^{452}$.

Trata-se de descrever os atos, buscando não tanto "o que é" (conceito) o pecado, mas "como" o pecado dilacerou a boa unidade diversa da alma. A descrição dos pecados não busca a explicação das causas da vontade corrompida, mas visa aprofundar o conhecimento de si como reconhecimento de limitude. Assim, como se anunciava o projeto das Confissões no livro I,1, as palavras da confissões foram

\footnotetext{
${ }^{451} \mathrm{cf}$. duab. an. X.12 Quibus concessis colligerem, nusquam scilicet nisi in voluntate esse peccatum.

${ }^{452}$ Le temps, comme le flux où s'evanouit la liberté et s'englutit la conscience, n'apparaît pas d'abord dans l'analyse conceptuelle de la stricte philosophie, mais dans le diagnostic atterrant du péché et de l'impuissance où il fige la volonté'. J. L. Marion, Augustin : Au lieu de soi. p. 274.
} 
doadas ao confessante para que este as reenvie ao doador tanto em forma de confissão da miséria quanto de louvação à Misericórdia; em outras palavras, tempo e Eternidade estão, desde o início da confissão, imbricados um ao outro em comprometimento de alcançar o desdobramento do conhecimento da alma e de Deus. Nas Confissões, a palavra final do movimento ascensional da alma ao criador não se dará pela pura contemplação de si, conversão por identidade. A estratégia é negativa, pela diferença do espanto: pela consternação produzida pela abertura de si aos seus olhos espirituais, trazendo à tona não a unidade, mas a diferença irredutível entre confessante e Deus. O encontro da unidade da alma com o criador unificador se dará nessa dupla face: diferença-identidade, isto é, a tomada de consciência da diferença de si consigo é condição da unidade possível de si com Ele e, consequentemente, reunião de si consigo.

Paradoxalmente, anseia-se pela transcendência e retorno ao Eterno Uno a partir da retomada de uma história individual errante; pois pecar nada mais é do que afastar-se do Eterno, vertendo-se desordenadamente no tempo em dilaceramento de unidade. $O$ arrependimento reconhece o pecado com fins de transcendência, pois, como foi dito: "que o pecado esteja diante Deus é precisamente o que ele tem de positivo" ${ }^{453}$. Destarte, do reconhecimento de limitude e do desejo de transcendência, nasce a possibilidade de, "pelo amor do teu amor" (amore amoris tui), ser reconjuntado da dispersão fragmentadora à unidade do puro Uno:

Quero recordar as minhas torpezas passadas, as corrupções de minha alma, não porque as ame, ao contrário, para te amar, ó meu Deus. É por amor do teu amor que retorno ao passado, percorrendo os

${ }^{453}$ Heidegger, M. Estudios sobre a Mística Medieval. Fondo de Cultura Economica. 1997. p. 121. 
antigos caminhos dos meus graves erros. A recordação é amarga, mas espero sentir tua doçura, doçura que não engana, feliz e segura, e quero recompor minha unidade depois dos dilaceramentos interiores que sofri quando me perdi em tantas bagatelas, ao afastar-me de tua Unidade. ${ }^{454}$

${ }^{454}$ conf. II,1. Recordari volo transactas foeditates meas et carnales corruptiones animae meae, non quod eas amem, sed ut amem te, Deus meus. Amore amoris tui facio istuc, recolens vias meas nequissimas in amaritudine recogitationis meae, ut tu dulcescas mihi, dulcedo non fallax, dulcedo felix et secura, et colligens me a dispersione, in qua frustatim discissus sum, dum ab uno te aversus in multa evanui. - Cotejo da tradução de Patrice Cambronne, Saint Augustin, Ouvres I. Éditions Gallimard, 1998. 


\section{REFERÊNCI AS BI BLIOGRÁFI CAS}

AGOSTINHO, Comentário aos Genesis. Tradução de Agustinho Belmonte. Coleção Patrística 21. São Paulo: Paulus 2005

AGOSTINHO, Confissões. Tradução de Arnaldo do Espírito Santo. Lisboa : Imprensa Nacional - Casa da Moeda, 2001

AGOSTINHO, Confissões. Tradução de J. Oliveira Santos e A. Ambrósio de Pina. Ed. Abril Cultural, São Paulo. 1980

AGOSTINHO, Confissões. Tradução de Maria Luiza Marante. Ed. Paulus, São Paulo. 2002

AGOSTINHO. Diálogo sobre a felicidade. (Edição bilingue). Trad. M. S. Carvalho. Lisboa: Edições 70, 1988

AGOSTINHO. Diálogo sobre a ordem. Trad. Silva, P. O. Lisboa, Imprensa Nacional/Casa da Moeda, 2000.

AgOSTINHO. O livre-arbítrio. Trad. Oliveira, N. A. Col. Patrística, São Paulo, Paulus, 1994.

AGOSTINHO. A doutrina cristã. Trad. Oliveira, N. A. Col. Patrística, 17. São Paulo: Paulus, 2002.

AGOSTINHO. A Trindade. Trad. Belmonte, A. Col. Patrística, 7. São Paulo: Paulus. 2005

AGOSTINHO. A verdadeira religião. Trad. Oliveira, N. A. São Paulo, Paulinas, 1987.

AGOSTINHO. A vida feliz. Trad. Oliveira, N. A. Col. Patrística, 11. São Paulo: Paulus, 1998.

AGOSTINHO. Contra acadêmicos, A ordem, A Grandeza da alma, O mestre. Trad. Agustinho Belmonte. São Paulo, Paulus, 2008 
AGOSTINHO. De Magistro. Col. Os Pensadores. São Paulo: Abril Cultural, 1972.

AGUSTIN, Obras de San Agustin: Del Génesis contra los Maniqueos. Del Génesis incompleto. Del Génesis a la letra. Biblioteca de Autores Cristianos -BAC. Tomo XV. Tradução: Fr. Balbino Martín. Madrid: La Editorial Católica, 1957

ALFARIC, Prosper. L'évolution intellectuelle de Saint Augustin. Paris: Ed. Nourry, 1918.

ALFLATT, Malcom. Responsibility for Involuntary Sin in Saint Augustine, In: Recherches augustiniennes, vol. 101975.

ALFLATT, Malcom. The Development of the Idea of Involuntary Sin in St. Augustine, In: Revue des études augustiniennes, Études Augustiniennes, 1974.

ARENDT, H. A. A vida do espírito: o pensar, o querer, o julgar. Rio de Janeiro : Civilização Brasileira, 2009.

ARENDT, H. A. Condição humana. Trad. Raposo, R. São Paulo: EDUSP, 2007.

ARENDT, H. A. O conceito de amor em Santo Agostinho. Trad. Dinis, A. P. Lisboa: Instituto Piaget, 1997

ARMSTRONG, A.H. Plotinus, A Volume of Selections in a New English Translation.. Allen and Unwin, 1953.

ARMSTRONG,Arthur Hilary Augustine and christian platonism, In: Villanova University. Lecture 1966.

AUERBACH, Erich. Ensaios de literatura ocidental. São Paulo: Editora 34, 2007.

AUGUSTIN, Saint. Les Confessions. Dialogues Philosophiques. Bibliothèque de la Pléiade, 1998 
AUGUSTIN. Confessions. Trad. P. Labriolle. Paris, Les Belles Lettres, 1990.

AUGUSTIN. Ouvres de Saint Augustin. La genèse au sens littéral. Institut d'études augustiniennes. BA 48-49. Brepols. Paris: 2011

AUGUSTIN. Ouvres de Saint Augustin. Les Confessions. Institut d'études augustiniennes. BA 13-14. Brepols. Paris: 1998

AUGUSTIN. Ouvres de Saint Augustin. Sur la genèse contre les manichéens. Institut d'études augustiniennes.BA 50 Brepols. Paris: 2004

AUGUSTIN. Soliloques. Traduction, introduction et notes: P. Labriolle, In: Ouvres de Saint Augustin. V. Dialogues philosophiques. Bibliothèque Augustinienne, vol V, 1948

AUGUSTINUS, Acta contra Fortunatum Manichaeum , F. Decret and J. van Oort (eds.) ; traduction : F. Decret Brepols 2004

AYOUB, C. N. A. Iluminação trinitária em Santo Agostinho. São Paulo: Paulus, 2011.

AYRES, Lewis. Augustine and the Trinity. Cambridge, UK ; New York: Cambridge University Press, 2010

BABCOCK, W. Augustine on Sin and Moral Agency. The J ournal of Religious Ethics, Vol. 16, No. 1 (Spring, 1988).

BABCOCK, W. Review. Images of Conversion in Augustine's Confessions by Robert J. O'Connell . Church History, Vol. 67, No. 1 (Mar., 1998), pp. 124126.

BAGUETTE, Ch. 'Une période stoïcienne dans l'evolution de la pensée de saint Augustin'. Le stoïcisme dans la formation de Saint Augustin. 1968

BARACAT, J osé Carlos, Júnior. Plotino, Sobre a Natureza, a Contemplação e o Uno (III. 8 [30]): introdução, tradução e comentário. 1. ed. Campinas: Editora da Universidade Estadual de Campinas, 2008 
BARACAT, J osé Carlos, Júnior. Plotino, Eneadas I,II e III ; Porfírio, Vida de Plotino. Introdução, tradução e notas. tese de doutorado. UNICAMP, 2006

BARROS, A. R. "O estoicismo moral de Cícero: virtudes e deveres para homens comuns". Phrónesis, Vol. 8, N. 2 Julho, 2006.

BEIERWALTES, Werner. Regio Beatitudinis. Augustine's Concept of Happiness. In : The Saint Augustine Lecture, 1980

BERMON, Emmanuel. La Signification Et L'enseignement: Texte Latin, Traduction Française Et Commentaire Du De Magistro De Saint Augustin. Paris: Librairie philosophique J. Vrin, 2007. p. 469.

BERMON, Emmanuel. Le Cogito Dans La Pensée De Saint Augustin. Paris: Vrin, 2001.

BOCHET, Isabelle. Augustin Dans La Pensée De Paul Ricoeur. Paris: Editions Facultés jésuites de Paris, 2004

BONNARDIÈRE, Anne-Marie. Saint Augustin et la Biblia. Paris: Beauchesne, 1986.

BOURKE, Vernon Joseph. Augustine's View of Reality. Villanova University Press, 1964

BOUTON-TOUBOULIC, Anne-Isabelle. L'ordre Caché: La Notion D'ordre Chez Saint Augustin. Paris: Institut d'études augustiniennes, 2004.

BOYER, Charles. Christianisme et néoplatonisme dans la formation de Saint Augustin. Roma: Officium Libri Catholici, 1953.

BOYER, Charles. L'Idée de vérité dans la philosophie de saint. Augustin. Thèse pour le doctorat ès lettres, présentée à la Faculté des lettres de I'Université de Paris. 1930

BRACHTENDORF, J. "Cicero and Augustine on the Passions". Revue des Études Augustiniennes, 43 (1997), p. 289-308. 
BRACHTENDORF, Johanes. Confissões de Santo Agostinho. São Paulo: Loyola, 2008

BRACHTENDORF, Johannes. "The Decline of Dialectic in Augustine's Early Dialogues". In: Studia Patristica XXXVIII, 2001

BRACHTENDORF, Johannes. The goodness of creation and the reality of Evil: Suffering as a problem in Augustine's Theodicy, In: Augustinian Studies 31: 1 (2000).

BRACHTENDORF, Johannes. The Reception of Augustine in Modern Philosophy. In: A Companion to Augustine (ed M. Vessey), Wiley-Blackwell, Oxford, UK. 2012

BREHIER, Émile. Histoire de la philosophie I. L'Antique et le Moyen âge. Librairie Félix Alcan, Paris: 1928.

BRISSON, Luc. Orphée, Pythagore et Platon. Le mythe qui établit cette lignée, In: Metaphysic und Religion. Leipzig, 2002

BROWN, Peter. Santo Agostinho: uma biografia. Editora Record. Rio de Janeiro, 2008

BRUZZONE, Andres. Hermêutica e subjetividade, de Agostinho e Hipona a Paul Ricoeur : Três estudos sobre o si, a memória e a identidade dissertação de mestrado. USP. São Paulo, 2012

BYERS, Sarah Catherine. Perception, Sensibility, and Moral Motivation in Augustine: A Stoic-platonic Synthesis. Cambridge [England] ; New York: Cambridge University Press, 2013.

CAMBRONNE, Patrice. Augustin et l'Église : Jalons d'un itinéraire Notes de lecture (Confessions, III-IV, 10). In: Vita Latina, $\mathrm{N}^{\circ} 115,1989$. pp. 22-36.

CICERO, M.T. The Academic Questions, Treatisde De Finibus and Tusculans Disputations of M.T. Cicero. London: Bell \& Daldy, Yorke Street, Covent Garde. 1872 
COURCELLE, Pierre Paul. Recherches Sur Les Confessions De Saint Augustin. Paris: E. de Boccard, 1950

COYLE, J.K. Saint Augustine's Manichaean Legacy, 2002 St. Augustine Lecture, In: Augustinian Studies 34: 1 (2003)

CRISTOFOLETTI, Fabricio Klain, A noção de eloqüência no De doctrina christiana de Agostinho de Hipona. Dissetação de mestrado, USP. São Paulo, 2010

DECRET, François. Aspects Du Manichéisme Dans L'Afrique Romaine: Les Controverses De Fortunatus, Faustus, Et Felix Avec Saint Augustin. Paris: Études augustiniennes, 1970.

DESCARTES, Discurso do método. Tradução de J. Guinsburg e Bento Prado Júnior. In: Obras incompletas. Coleção Os Pensadores. São Paulo: Abril Cultural, 1973.

DESCARTES, Meditações. Tradução de J. Guinsburg e Bento Prado Júnior. In: Obras incompletas. Coleção Os Pensadores. São Paulo: Abril Cultural, 1973.

DESCARTES, Fuvres. Org. Charles Adams \& Paul Tannery. 11 vols. Paris: Librarie Philosophique J. Vrin, 1971

DILLON, John. Plotinus at Work on Platonism. Greece \& Rome, Second Series, Vol. 39, No. 2 (Oct., 1992)

DOUCET, Dominique. Être-Vie-Pensée in Augustin, l'experiénce du Verbe. Paris: Librairie Philosophique J. Vrin, 2004.

DOUCET, Dominique. Recherche de Dieu, Incarnation et philosophie: Sol I,1,2-6. In : Revue des Études Augustiniennes 36 (1990).

DU ROY, Olivier. L'intelligence de la foi en la Trinité selon Saint Augustln: genèse de sa théologie trinitaire jusqu'en 391. Paris: Institut d“Études Augustiniennes, 1966. 
DU ROY, Olivier. La situation médiane de l'âme pp. 476-478 . In. L'Intelligence De La Foi En La Trinité Selon Saint Augustin. Paris: Études augustiniennes, 1966

DU ROY, Olivier. Note a "L"intelligence de la foi en la Trinité selon Saint Augustl n: genèse de sa théologie trinitaire jusqu“en 391". In: Révue des Études Augustiniennes 13 (1967).

DUBREUCQ, E. Augustin et le scepticisme académicien. Recherches de Science Religieuse 86. 1998.

FERRARI, Leo. The Convertions of Saint Augustine. Villanova University Press, 1986.

FERRAZ, Marin. De La Psychologie De Saint Augustin. Deuxieme edition. Paris: Ernest Thorin, 1869

FERWERDA, R. Two Souls. Origen's and Augustine's Attitude toward the Two Souls Doctrine. Its Place in Greek and Christian, In: Philosophy Vigiliae Christianae Vol. 37, No. 41983

FINAERT, J oseph. L'évolution littéraire de Saint Augustin. Paris: Les Belles Lettres, 1939

FITZGERALD, Allan., and John C Cavadini. Augustine Through the Ages: An Encyclopedia. Grand Rapids, Mich.: W.B. Eerdmans, 1999

FLETEREN, Frederick. Augustine's Rejection of the Fall of the Soul, In: Augustinian Studies 4 (1973).

FLOREZ, Ramiro. Las dos dimensiones del hombre augustiniano. Madrid: Ediciones Religión y Cultura, 1958.

GIANNOTTI, J. A. Lições de filosofia primeira - São Paulo : Companhia das Letras, 2011

GILSON, E., "The Future of Augustinian Metaphysics," In: A Gilson Reader . Garden City, N. Y.: Doubleday Image, 1957 
GILSON, Étienne. Introdução ao estudo de Santo Agostinho. São Paulo: Discurso Editorial-Paulus, 2006

GILSON, Etienne. Le cogito e la tradition augutinienne, In : Le rôle de lá penseé médiévale dans la formation du système cartésien, Paris 1930

GILSON, Etienne. O Espírito da Filosofia Medieval. Martins Fontes, 2006.

GOLDSCHMIDT, V. Exégèse et axiomatique chez saint Augustin. In Écrit, tome 1, Études de Philosophie Ancienne. Paris: Librairie Philosophique J. Vrin, 1984

GUÉROULT, Martial. Descartes selon l'ordre des raisons. Paris : Aubier, 1968.

GUITTON, J. Le temps et l'éternité chez Plotin et Saint Augustin. Paris: Boivin, 1933

HADOT, P. Etre, vie, pensée chez Plotin et avant Plotinin : Le Sources de Plotin, 1957

HADOT, P. La notion d'infini chez saint Augustin, Philosophie (26), p. 5972. Paris, 1990

HADOT, P. O que é a Filosofia Antiga?. Rio de Janeiro: Loyola, 1999

HADOT, Pierre. Plotin ou la simplicité du regard. Études Augustiniennes. Paris 1973

HANKEY, Wayne. Between and Beyond Augustine and Descartes: More than a Source of the Self; In: Augustinian Studies 32: I (2001)

HANKEY, Wayne. Stephen Menn's Cartesian Augustine: Metaphysical and Ahistorically Modern. In: Animus 3, 1998.

HEIDEGGER, M. Estudios sobre a Mística Medieval. Fondo de Cultura Economica. Mexico: 1997.

HEIDEGGER, Question III et IV, Paris : Galimmard. 1990 
HENRY, Michel. C'est Moi La Vérité: Pour Une Philosophie Du Christianisme. Paris: Editions du Seuil, 1996.

HEßBRÜGGEN-WALTER, S. “Augustine's Critique of Dialectic: Between Ambrose and the Arians," in: Augustine and the Disciplines: From Cassiciacum to Confessions, ed. K. Pollmann and M. Vessey. Oxford: Oxford University Press, 2005.

HORN, C. La vie chez Plotin. In: Penser la vie. Contributions de la philosophie. Coloques interationaux. Etude de Lettres 3-4. 2008. Org. par Michel Herren et Igenborg Shussler

HORN, Christoph. Aspects of biology in Plotinus. Published to Oxford Scholarship Online: 2012

HUSSERL, E. Idéias para uma fenomenologia pura e para uma filosofia fenomenológica : introdução geral à fenomenologia pura. Trad. M. Suzuki -Aparecida : I déias \& Letras, 2006

IAMBLICHUS, De Anima I,6-7. John F. Finamore, and John M Dillon. . Leiden; Boston, MA: Brill, 2002

INWOOD, Ethics and Human Action in Early Stoicism, Oxford: Clarendon, 1985

JOLIVET,R. notes In : Ouvres de Saint Augustin. Six traités anti-manichéens Bibliothéque Augustinienne. BA 17. Desclée de Brouwer. 1961

JONAS, Hans, La religion gnostique. Le message du Dieu Étranger et les débuts du christianisme. Paris. Flammarion. 1978

KAHN, Charles H. Discovering the will: from Aristote to Augustine, In: DILLON, J.M. (ed.), The question of "Eclecticism": Studies in Later Greek Philosophy. Bercheley: University of California Press, 1996.

KING, Peter. Augustine's encounter with neoplatonism. The Modern Schoolman Volume 82, Issue 3, March 2005 
KOTZÉ, Annemaré. Augustine's Confessions: Communicative Purpose and Audience. Leiden ; Boston: Brill, 2004.

LAURENT, Jérôme. "Peccatum nihil est". Remarques sur la concpetion augustinienne du péché comme néant. In: Cahiers Philosophiques n. 122, 2010

LAVIGNE, Jean-François. Husserl Et La Naissance De La Phénoménologie, 1900-1913: Des Recherches Logiques Aux Ideen : La Genáese De L'idéalisme Transcendantal Phénoménologique. 1re éd. Paris: Presses universitaires de France, 2005.

LE BLOND, Jean Marie. Les Conversions De Saint Augustin. Paris: Aubier, 1950

LÉVY, C. Cicero Academicus - Recherches sur les Académiques et sur la philosophie cicéronienne. Paris: École Française de Rome, 1992

LÉVY, Carlos. Cicero academicus recherches sur les Académiques et sur la philosophie cicéronienne. Roma : École Française de RomeCollection de l'École Française de Rome, 1992.

LIENHARD, E. Augustine. Prebyster Factus Sum. Collectanea Augustiniana. Edited J oseph T. Lienhard, E. Muller, R. Teske. Marqueette University, 1990

Lienhard, J.T. “Augustine on Dialectic: Defender and Defensive" StPat 33 1997

LIENHARDT, J.T. Augustine on Dialectic: Defender and Defensive . In Studia Patristica XXXIII, 1997

LIMA, S.C. Oradores e filósofos no De finibus de Cícero. Tese de doutorado Ano de Obtenção: UNICAMP. 2009.

LONG, A. A. Problems in Stoicism. London: The Athlone Press, 1996.

LONG, A. A. Epictetus: A Stoic and Socratic Guide to Life. Oxford : New York: Clarendon Press, 2002 
LOSSL, Josef. The One (unum) - A guiding concept in De vera religione. In : Revue d'Etudes Augustinienne,40, 1944

MADEC, G. Augustin et le néoplatonisme, In: Revue de I'Institut catholique de Paris, 19 , 1986.

MADEC, G. L'Hortensius de Cicéron dans les livres XIII-XIV du "De Trinitate". In : Revue des études augustiniennes (Paris) vol. 15, 1969

MADEC, G. Platonisme et christianisme. Analyse du livre VII des Confessions. In: Caron, Maxence, et al. Saint Augustin. Cerf, 2009.

MADEC, Goulvean. Conversion, Intériorité, Intentionnalité. In : Petites Études Augustiniennes. Paris: Institut d'études augustiniennes, 1994.

MADEC, Goulvean. Conversion, Le Spiritualisme Augustinen. In :. Petites Études Augustiniennes. Paris: Institut d'études augustiniennes, 1994.

MADEC, Goulvean. De Libero Arbitrio, théodicée, In: Saint Augustin et la Philosophie: notes critiques. Paris: Institut d“Études Augustiniennes, 1996.

MADEC, Goulvean. Introductión aux "Révisions" et à la lecture des oeuvres de saint Augustin. Paris: Institut d“Études Augustiniennes, 1996.

MADEC, Goulvean. La Patrie et la Voie. Le Christ dans la vie et la pensée de saint Augustin. Paris: Desclée de Brouwer, 1989.

MADEC, Goulvean. Le néoplatonisme dans la conversion d'Augustin. Etat d'une question centenaire (depuis Harnack et Boissier, 1888), In: MAYER, Cornelius Petrus. Internationales Symposium über den Stand der Augustinus-Forschung. Würzburg: Augustinus-Verlag, 1989.

MADEC, Goulvean. Mens, imago Dei, In: Saint Augustin et la Philosophie: notes critiques. Paris: Institut d'Etudes Augustiniennes, 1996.

MADEC, Goulvean. Notes sur l'intelligence augustinienne de la foi, In: Révue des Études Augustiniennes 17 (1971). 
MADEC, Goulvean. Notes: Augustin, disciple et adversaire de Porphyre, In: Révue des Études Augustiniennes 10 (1964).

MADEC, Goulvean. Une lecture de Confessions VII,ix,13-xxi,27: notes critiques à propôs d'une thèse de R. J. O'Connell, In: Révue des Études Augustiniennes 16 (1970).

MAMMì, Lorenzo. Agostinho e as artes : dos diálogos filosóficos às Confissões. Livre docência, USP. São Paulo, 2009

MAMMì, Lorenzo. Canticum Novum. Música sem palavras e palavras sem som no pensamento de Santo Agostinho. In: Estudos Avançados 14 (38), 2000.

MAMMì, Lorenzo. O que Resta. São Paulo: Companhia das Letras, 2012

MAMMì, Lorenzo. Santo Agostinho, o tempo e a música. Tese de Doutorado, USP. São Paulo, 1998

MAMMI, Lorenzo. Stillae Temporis: interpretação de uma passagem das Confissões, XI, 2. In: Palacios, Pelayo Moreno (Org) Tempo e razão: 1600 anos das Confissões de Agostinho. São Paulo: Edições Loyola, 2002

MARION, Jean-Luc. Sur l'ontologie grise de Descartes : science cartésienne et savoir aristotelicien dans les regulae; ouvrage publié avec le concours du Centre National de la Recherche Scientifique -- Paris : J. Vrin, 1975.

MARION, Jean-Luc. Au Lieu De Soi: L'approche De Saint Augustin. 1re éd. Paris: Presses universitaires de France, 2008

MARKUS, R. A. «Imago» and «similitudo» in Augustine. In: Revue des Études Augustiniennes 10 (1964).

MARKUS, R. A. Men: soul and body In: Armstrong, A. H. The Cambridge History of Later Greek and Early Medieval Philosophy. London: Cambridge U.P., 1967 
MARKUS, R. A. Conversion and Disenchantment In: Augustine's Spiritual Career. [Villanova, Pa.]: Villanova University Press, 1989.

MARQUES, Maria Janaina Brenga. O livre-arbítrio em Agostinho. Tese de doutorado, USP. São Paulo, 2012

MATHEWS, G. Augustine on Reasoning from One's Own Case. In: Medieval Philosophy and Theology. pp. 115-128, 1988.

MATHEWS, G. Augustine on Reasoning from One's Own Case. In: Medieval Philosophy and Theology. 1988

MATHEWS, G. Augustine on Reasoning from One's Own Case. In: Medieval Philosophy and Theology, Volume 7, 2 (September 1998)

MATTHEWS, Gareth B. Thought's Ego in Augustine and Descartes. Cornell University Press. 1992.

MECONI, David Vincent. St. Augustine's early theory of Participation, In: Augustinian Studies 27:2 (1996).

MENEZES, A, A história do discurso sobre as paixões nas Tusculanas de Cícero. In: Cadernos Espinosanos XXIV, 2011

MENN, S. Descartes and Augustine. Cambridge: Cambridge University Press, 1998

MENNEL, S. Augustine's "I": The "Knowing Subject" and the Self. In: J ournal of Early Christian Studies, Volume 2, Number 3, Fall 1994.

MILBANK, J ohn. "Intensities" In: Modern Theology 15.4 (1999)

MOHRMANN, Christine. Saint Augustin écrivain, In: Études sur le latin des Chrétiens, tomo II. Roma: Edizioni di Storia e Litteratura, 1961.

MOMMSEN, TH. "St. Augustine and the Christian Idea of Progress", J ournal of the History of Ideas XII (1951), In: DONNELLY, D. F. The City of God A Collection of Critical Essays. New York: PETER LANG, 1995 
NOVAES, Moacyr . Vontade e contravontade, In: NOVAES, A., org., O avesso da liberdade. São Paulo, Companhia das Letras, 2002; p. 59-76.

NOVAES, Moacyr. A razão em exercício: estudos sobre a filosofia de Agostinho. São Paulo: Paulus/Discurso Editorial, 2009.

NOVAES, Moacyr. Eternindade, interioridade sem sujeito. In: Analítica , Rio de Janeiro. vol 9 (1). 2005

NOVAES, Moacyr. Interioridade e inspeção do espírito na filosofia agostiniana. In: Analytica, Rio de Janeiro, v. 7, n. 1, 2003.

NUMÉNIUS, Fragments 44. Paris : Les Belles Lettres, 1973

O'BRIEN, Denis. Pondus meum amor meus (conf. XIII,9.10): saint Augustin et J amblique, In: Studia Patristica 16 (1985).

O'CONNELL, Robert J. Augustine's exegetical use of Ecclesiasticus 10,9-14, In: VAN FLETEREN, Frederick. Augustine, biblical exegete. New York: Peter Lang, 2004.

O'CONNELL, Robert J. St. Augustine's Confessions: the Odyssey of soul. New York: Fordham University Press, 1989

O'CONNOR, William Riordan. The uti/frui distinction in Augustine"s Ethics, In: Augustinian Sudies 14 (1983).

O'DALY, G. Augustine's City of God: a reader's guide. Oxford: Oxford University Press, 1999.

O'DALY, Gerard J. P. Augustine's Philosophy of Mind. Berkeley: University of California Press, 1987.

O'DALY, Gerard J. P. Platonism Pagan and Christian: Studies in Plotinus and Augustine. Aldershot: Ashgate, 2001.

O’DONNELL, James Joseph. Augustine. Boston: Twayne Publishers, 1985. 
O'MEARA, John Joseph. The Young Augustine: The Growth of St. Augustine's Mind Up to His Conversion. London, New York: Longmans, Green, 1954.

O'CONNELL, Robert J. De libero arbitrio I: Stoicism Revisited. In : Augustinian Studies, vol 58 (1970)

OORT, J.V Otto, 1989, 'Augustine on sexual concupiscence and original sin', In: Studia Patristica XXII, Leuven, Peeters, 382-386

OORT, J.V Otto WERMELINGER, and Gregor WURST. Org. Augustine and Manichaeism in the Latin West: Proceedings of the Fribourg-Utrecht International Symposium of the International Association of Manichaean Studies (IAMS). Leiden ; Boston: Brill, 2001

OORT, Van. Augustine and manichaeism: new discoveries, new perspectives, In: Verbum et Ecclesia, 27(2). 2006

OORT, Van. Manichaeism: its sources and influences on western christianity, In: Verbum et Ecclesia 30(2). 2009

PAFFENROTH, Kim, \& KENNEDY, Robert Peter. A Reader's Companion to Augustine's Confessions. Louisville, Ky:: Westminster John Knox Press, 2003.

PALACIOS, Pelayo Moreno. O estamento da verdade no contra academicos de Agostinho - tese de doutorado. USP. São Paulo, 2006.

PEGNON, J. In: Augustine, Saint. Fuvres De Saint Augustin. Paris: Desclée de Brouwer, 1936

PEPIN, J. Une curieuse déclaration idéaliste du "De Genesi ad Litteram" de saint Augustin, et ses origines plotiniennes : remarques sur une citation paulinienne des "Confessions" de saint Augustin. Paris : In: Revue de d'histoire et de philosophie religieuses, vol. 34, 1954.

PEPIN, Jean. «Le problème de la communication des consciences chez Plotin et saint Augustin», In: Revue de Métaphysique et de Morale 55, 1950 
PEPIN, Jean. Idées Grecques Sur L'homme Et Sur Dieu. Paris: les Belles lettres, 1971.

PETREMENT, S. Le dualisme chez platon, les gnostiques et les manicheens - Paris : Puf, 1947

PLATÃO, O Sofista. Tradução de Carlos Alberto Nunes, UFB 1980.

PLATÃO. Fédon. tradução de Maria T. S. de Azevedo. Brasília: Editora Universidade de Brasília. São Paulo. Imprensa Oficial do Estado, 2000

PLOTINO. Enéadas: libros III y IV. Madrid: Editorial Gredos. 1985

PLOTINO. Enéadas: libros V y VI. Madrid: Editorial Gredos. 1998

PLOTINUS.,. The Enneads. Stephen Mackenna, and B. S Page 3d ed. London: Faber and Faber, 1962.

PLOTINUS.,Ennéades. Emile Bréhier Paris: Société d'édition "Les Belles Lettres", 1956.

PORFÍRIO. Vida de Plotino, Enéadas: libros I y II. Introducciones, traducionnes y notas de Jesús I gal. Madrid: Editorial Gredos. 1982

PUECH, H-,C. Histoire des Religions. vol II. Paris. Gallimard, 2004.

PUECH, H-C. Plotin e le gnostiques : Le Sources de Plotin, 1957

RICOEUR, Paul. Finitude et culpabilité. V.1 (l'homme faillible). V.2 (la symbolique du mal). Paris: Aubier, 1960

RICOEUR, Paul. O "pecado original": estudo de significação, In O conflito das interpretações. Ensaios de hermenêutica. Porto: Res Editora, 1989

RICOEUR, Paul. O mal: um desafio à Filosofia e à Teologia. Campinas: Papirus, 1988.

RICOEUR, Paul. Tempo e narrativa. Campinas: Papirus, 1997. 
RICOEUR, Paul. Le Conflit Des Interprétations: Essais D'herméneutique. Paris: Éditions du Seuil, 1969.

RICOEUR,Paul. Étude sur les « Méditations Cartésiennes » de Husserl, In: Revue Philosophique de Louvain. 1954 Volume 52 Numéro 33

RIES, J. Manichaeism. In: New Catholic Encyclopedia. Vol.. 2nd ed. Detroit: Gale, 2003. p106-115

RIES, J.Introduction Aux Études Manichéennes. [Louvain]: Publications universitaires de Louvain, 1957.

RIGBY, Paul . Original sin. In: Augustine"s "Confessions". Ottawa: University of Ottawa Press, 1987.

RIGBY, Paul. Crítica a la interpretación de Paul Ricoeur sobre la doctrina agustiniana del pecado original, In: Augustinus 31 (1986).

SAFFREY, H. D.. La théurgie chez les néoplatoniciens, In : Recherches sur le Néoplatonisme après Plotin. París, 1990

SAGE, Athanase. Le péché originel dans la pensée de saint Augustin, de 412 à 430, In: Révue des Études Augustinennes 14 (1968).

SAGE, Athanase. Péché originel. Naissance d'um dogme, In: Révue des Études Augustinennes 13 (1967).

SCIBONA, C.G. The doctrine of the soul in manichaeism. In: Oort, J. van, and Jacob Albert van den Berg. 'In Search of Truth': Augustine, Manichaeism and Other Gnosticism : Studies for Johannes Van Oort At Sixty. Leiden ; Boston: Brill, 2011.

SILVA FILHO, L. M. A definição de populus n'A cidade de Deus de Agostinho: uma controvérsia com Da república de Cícero. Dissertação de Mestrado em Filosofia, São Paulo, USP, 2008

SILVA FILHO, L.M. Desnaturalização da política n'A cidade de Deus, de Agostinho Tese de Doutorado, USP. São Paulo, 2012 
SILVA, Franklin Leopoldo, Descartes : a metafísica da modernidade. São Paulo : Moderna, 1996

SILVA, Franklin Leopoldo. Tempo e Experiência. In: Revista USP, num. 81, São Paulo março/maio 2009

SOLIGNAC, Aimé . Augustin et la science médicale, In: Bibliothèque Augustinienne 48 .1972.

SOLIGNAC, Aimé. Réminiscenses plotiniennes et porphyriennes dans le début du "De Ordine" de saint Augustin, In: Archives de Philosophie 20 (1957).

SOMERS, Hermann. Image de Dieu. Les sources de l'exégèse augustinienne, In: Revue des Études Augustiniennes 7 (1961).

SORABJI, R. Emotion and Peace of Mind. From Stoic Agitation to Christian Temptation. Oxford \& New York: Oxford University Press, 2002

STEEL, Carlos. ‘Neoplatonism', In: Gale's Encyclopedia of Philosophy. 2005

STOCK, B. Augustine the reader: meditation, self-knowledge, and the ethics of interpretation. Cambridge, Mass: Harvard University Press, 1998

STROUMSA, GG and FREDRIKSEN,P. The Two Souls and Divided Will. In: Jacob Taubes Minerva Center for Religious Anthropology., Albert I Baumgarten, Jan Assmann, and Gedaliahu A. G Stroumsa. Self, Soul, and Body in Religious Experience. Leiden ; Boston: Brill, 1998.

TAYLOR, C. Sources of the self : the making of the modern identity. Cambridge, Mass: Harvard University Press, 1989

TESKE, Roland J. St. Augustine's view of the original human condition in “De Genesi contra Manichaeos”. In: Augustinian Studies 22 (1991).

TESKE, Roland J. To Know God and the Soul: Essays On the Thought of Saint Augustine. Washington, D.C.: Catholic University of America Press, 2008 
TESKE, Roland. Augustine, Saint,. The Manichean Debate. Hyde Park, N.Y.: New City Press, 2006.

TESKE, Roland. Augustine's theory of the soul. In: The Cambridge Companion to Augustine. Cambridge: Cambridge University Press, 2006

THOMPSON, Samantha. Augustine on sufering and order: punishment in context. Universityof Toronto, 2010

THOMPSON, Samantha. What goodness is: order as imitation of unity in Augustine. In: The Review of Methaphysics 65, March 2012.

THONNARD, François-Joseph . La notion de concupiscence en philosophie augustinienne, In: Recherches Augustiniennes 3 (1965)

THONNARD, François-Joseph . La notion de liberté en philosophie augustinienne, In: Revue des Études Augustiniennes 16 (1970).

THONNARD, François-Joseph. La notion de nature chez S. Augustin, in: Revue des Etudes Augustiennes 11, 1965.

TORCHIA, N.J. The significance of ordo-ordem in Augustine's Moral Theory, In: Augustine. Prebyster Factus Sum. Collectanea Augustiniana. Edited J oseph T. Lienhard, E. Muller, R. Teske. Marqueette University, 1990.

TREGO, Kristell. L'âme ete la vonlonté chez saint Augustin. In: Caron, Maxence, et al. Saint Augustin. Cerf, 2009.

TROUILLARD, Jean. L'impeccabilité de l'esprit, selon Plotin. In: Revue de I'histoire des religions, tome $143 \mathrm{n}^{\circ} 1$, 1953. pp. 19-29.

VAN FLETEREN, Frederick. Augustine's ascent of the soul in Book VII of the Confessions: a reconsideration, In: Augustinian Studies 5 (1974).

VAN FLETEREN, Frederick. Augustine's evolving exegesis of Romans 7:2223 in its Pauline context, In: Augustinian Studies 32: 1 (2001).

VANNIER, Marie-Anne. "Creatio", "Conversio", "Formatio" chez s. Augustin. Fribourg: Éditions Universitaires, 1997. 
VARGAS, Walterson José. Soberba e humildade em Agostinho de Hipona. Tese de doutorado. São Paulo: USP, 2011.

VERBEKE, Gerard. Augustin et le stoïcisme, In: Recherches Augustiniennes 1 (1958).

VOELKE, A-J. L'idée de volonté dans le stoïcisme. Paris: PUF, 1973.

WETZEL, James. The question of consuetudo carnalis in Confessions VII, 23. In: Augustinian Studies $31: 22000$

WETZEL, James. Augustine and the Limits of Virtue. Cambridge. New York, NY: Cambridge University Press, 1992 
